HELLEM DE FREITAS MIRANDA

\title{
MOBILIDADE URBANA SUSTENTÁVEL E O CASO DE CURITIBA
}

Dissertação apresentada à Escola de Engenharia de São Carlos da Universidade de São Paulo, como parte dos requisitos para a obtenção do Título de Mestre em Ciências, Programa de Pós-Graduação em Engenharia de Transportes - Área de Concentração: Planejamento e Operação de Sistemas de Transportes.

ORIENTADOR: Prof. Assoc. Antônio Nélson Rodrigues da Silva

São Carlos

2010 


\begin{abstract}
AUTORIZO A REPRODUC̄̃O E DIVULGACÃO TOTAL OU PARCIAL DESTE TRABALHO, POR QUALQUER MEIO CONVENCIONAL OU ELETRÔNICO, PARA FINS DE ESTUDO E PESQUISA, DESDE QUE CITADA A FONTE.
\end{abstract}

Ficha catalográfica preparada pela Seção de Tratamento da Informação do Serviço de Biblioteca - EESC/USP

Miranda, Hellem de Freitas
M672t Mobilidade urbana sustentável e o caso de Curitiba / Hellem de Freitas Miranda ; orientador Antônio Nélson Rodrigues da Silva. -- São Carlos, 2010.

Dissertação (Mestrado-Programa de Pós-Graduação em Engenharia de Transportes. Área de Concentração em Planejamento e Operação de Sistemas de Transportes -- Escola de Engenharia de São Carlos da Universidade de São Paulo, 2010 .

1. Mobilidade urbana sustentável. 2. Indicadores urbanos. 3. Indicadores de mobilidade. 4. Índice de mobilidade urbana sustentável. 5. Planejamento da mobilidade. 6. Curitiba. I. Título. 
FOLHA DE JULGAMENTO

Candidata: Arquiteta e Urbanista Hellem de Freitas Miranda

Título da tese: MOBILIDADE URBANA SUSTENTÁVEL E O CASO DE CURITIBA

Data da defesa: 13/10/2010:

Comissão Julgadora:

Prof. Associado Antônio Nélson Rodrigues da Silva (Orientador) (Escola de Engenharia de São Carlos/EESC)

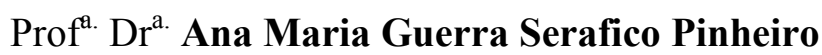

(Universidade Federal do Pará)

Prof $^{\text {a. }} \operatorname{Dr}^{\text {a. }}$ Katia Livia Zambon

(Universidade Estadual Paulista (UNESP) - Campus de Bauru)
Resultado:

APROVADA

APROVADA

APROVADA

Coordenador do Programa de Pós-Graduação em Engenharia de Transportes:

Prof. Associado Paulo Cesar Lima Segantine

Presidente da Comissão de Pós-Graduação:

Prof. Associado Paulo Cesar Lima Segantine 

Para minha mãe Tânia, pelo esforço, dedicação e muito carinho. 

Ao Prof. Dr. Antônio Nélson Rodrigues da Silva, pela dedicação, atenção e paciência dispensadas a mim na realização deste trabalho.

Ao meu pai, por tanto valorizar minha educação e sempre incentivar sua continuidade.

Às minhas irmãs, Cristiane e Alessandra, e meus cunhados Cristiam e Vinicio, por acreditarem no meu potencial e tornarem meu sonho possível.

Aos meus avós, Osmar e Leoni, por sempre acreditarem em mim e me apoiarem nas minhas escolhas.

Ao Victor, por seu amor, carinho e companheirismo que se tornaram tão essenciais nesta jornada. E principalmente pela incansável paciência que tanto me ajudou a atingir meus objetivos.

Aos meus "irmãos" Marcelo e Mário por tantos momentos de pura descontração e alegria, além dos muitos cafés filosóficos com discussões aprofundadas sobre o desenvolvimento desse trabalho. E também à Fabíola, nossa "irmã mais velha", por seu incentivo.

Aos amigos do STT, em especial: Vivian, Luis, Gustavo, Karlinha, Tiago, Wallace, Rochelle, Marcela, pelos momentos de alegria e descontração, além das inúmeras conversas e apoio nos momentos de desânimo.

Ao Paulo, pela amizade e companheirismo em São Carlos e acolhida na minha mudança de cidade.

Aos professores do Departamento de Transportes, em especial ao Prof. Dr. Paulo Cesar Lima Segantine, ao Prof. Dr. Antonio Clóvis Pinto Ferraz e ao Prof. Dr. José 
Leomar Fernandes Jr., pelos conhecimentos compartilhados e amizade ao longo do programa de mestrado.

Aos funcionários do STT, Magali, Heloísa, Bete e Alexandre, pela alegria com que desempenham seus trabalhos e também pelos inúmeros serviços prestados.

À Prof. Suely da Penha Sanches, da Universidade Federal de São Carlos, pelas generosas sugestões para o desenvolvimento desse estudo.

À Prefeitura Municipal de Curitiba, em especial aos funcionários Oscar Ricardo Schmeiske (IPPUC), Anive Alcantara Soares (URBS), Luiz Filla (URBS) e Alvacir Gonçalves Mendes (DIRETRAN), pelas valiosas informações fornecidas, essenciais para a realização desse trabalho.

À CAPES pelo apoio financeiro prestado ao longo do programa de mestrado. 
SUMÁRIO 1

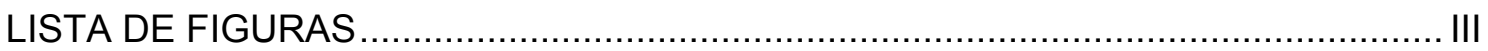

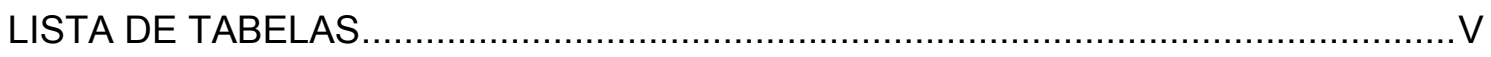

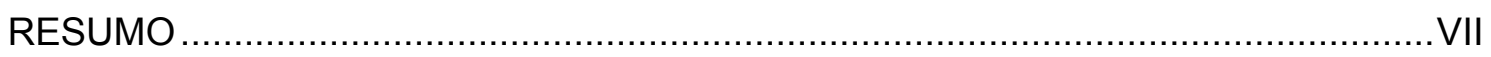

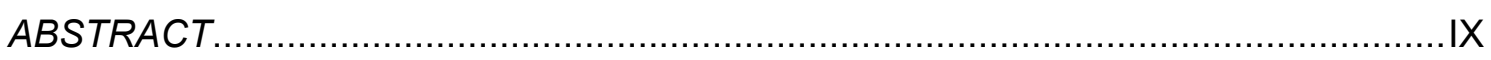

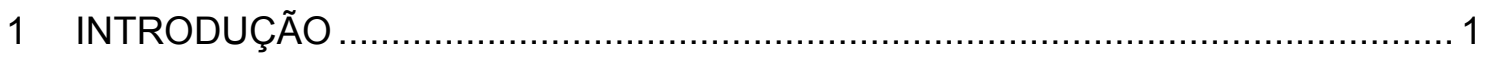

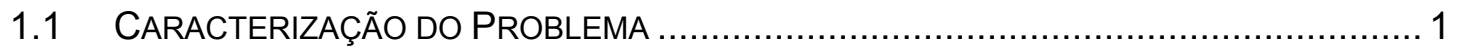

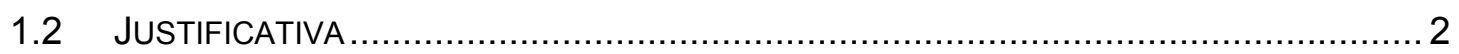

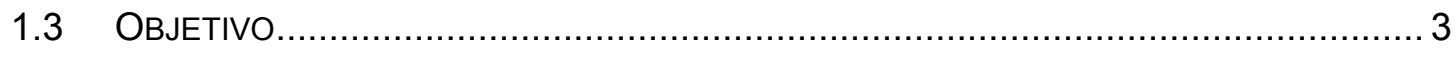

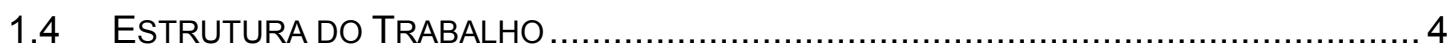

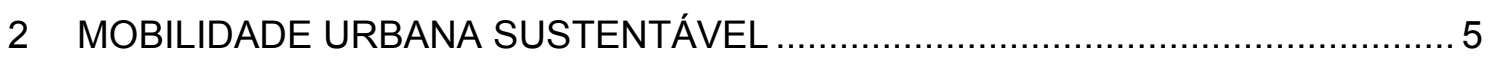

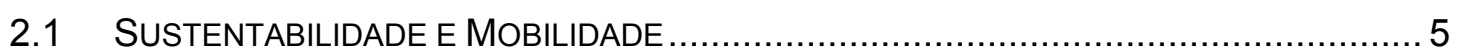

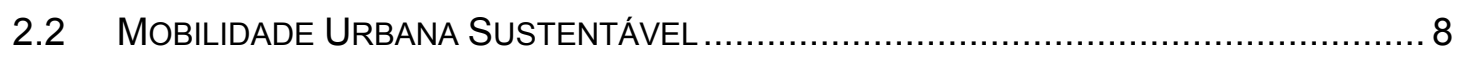

2.2.1 Mobilidade urbana sustentável no Brasil .......................................... 10

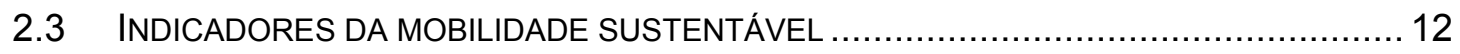

2.3.1 IMUS - Índice de Mobilidade Urbana Sustentável .................................. 14

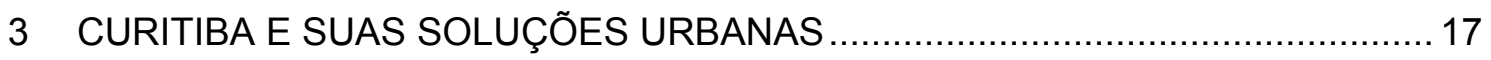

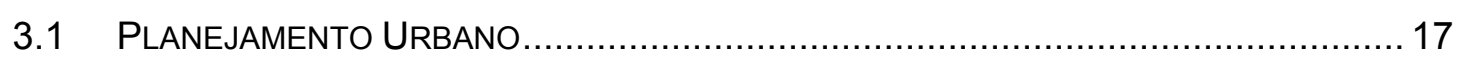

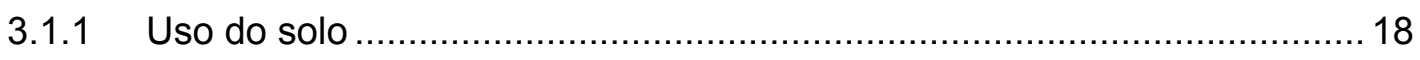

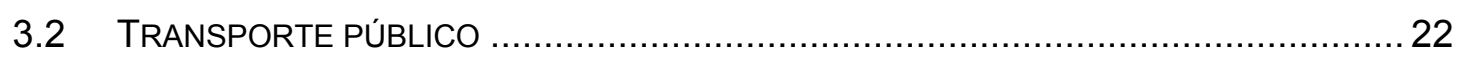

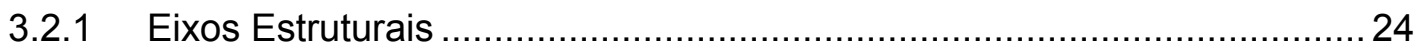

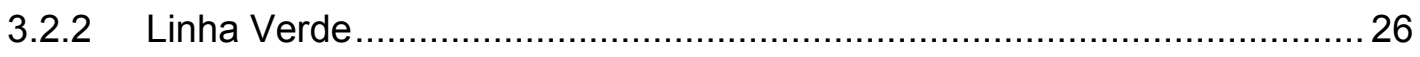

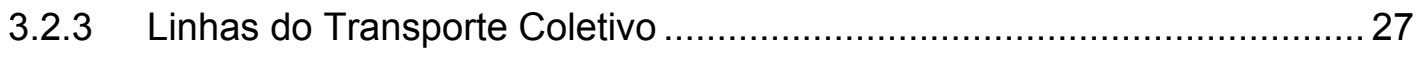

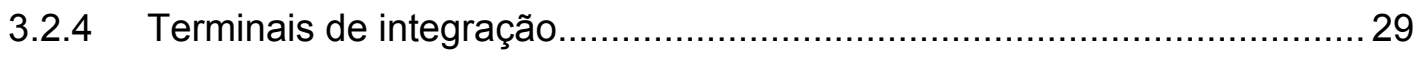

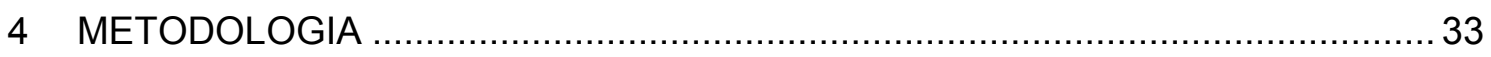

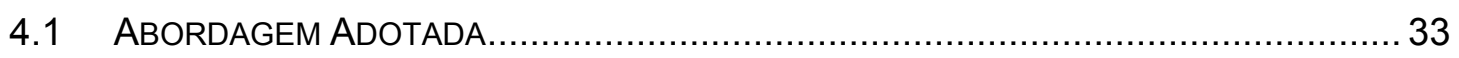

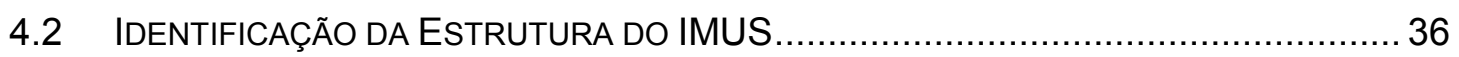

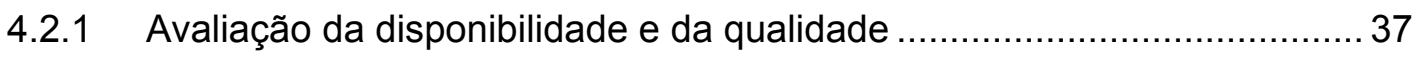

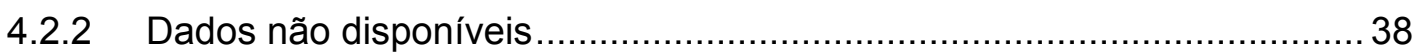




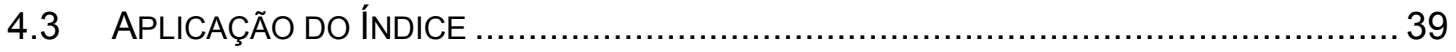

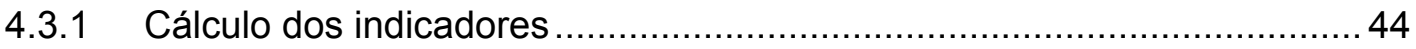

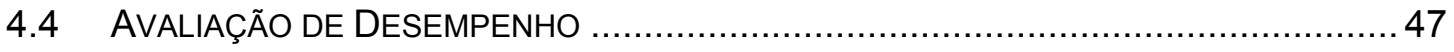

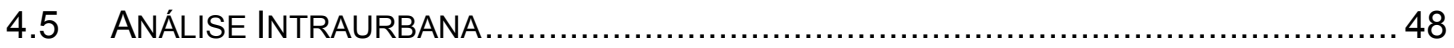

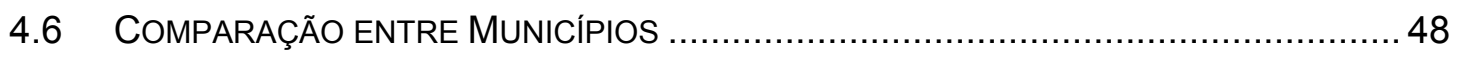

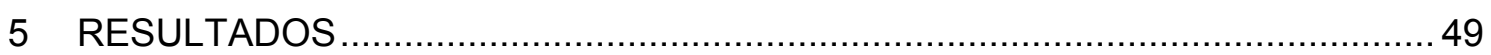

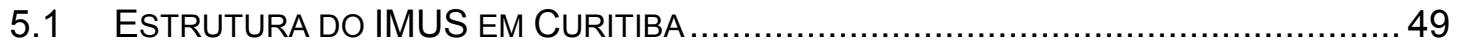

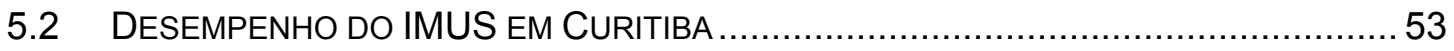

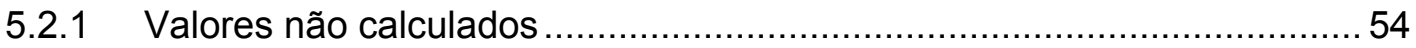

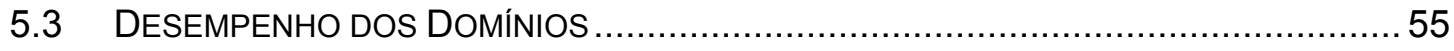

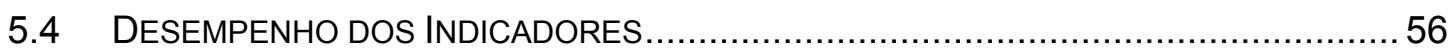

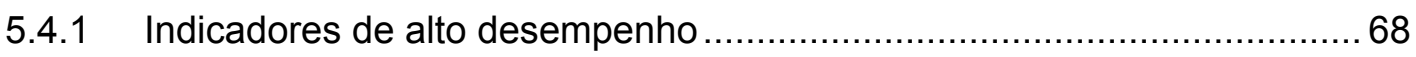

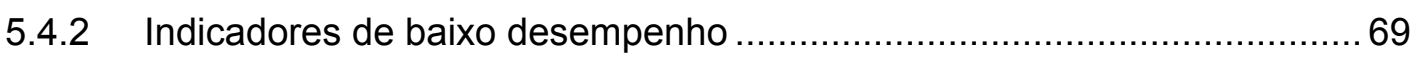

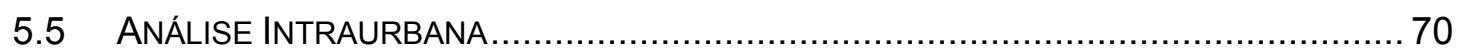

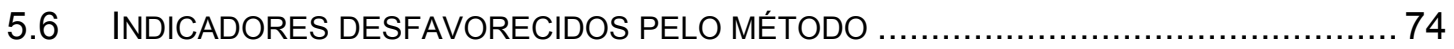

5.6.1 Indicadores com método de cálculo a ser revisto .................................... 77

5.6.2 Fragmentação urbana ....................................................................... 77

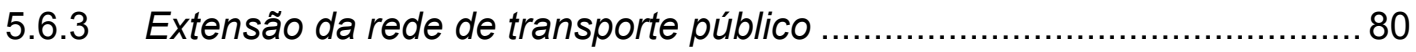

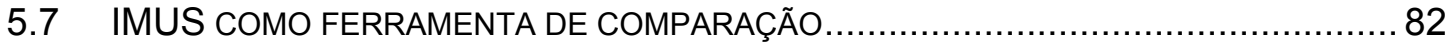

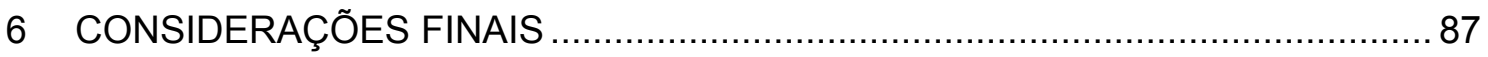

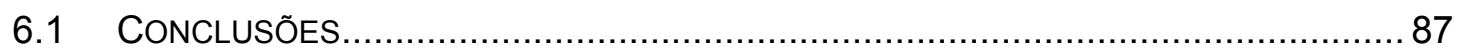

6.2 RECOMENDAÇÕES PARA TRABALHOS FUtUROS ………............................... 90

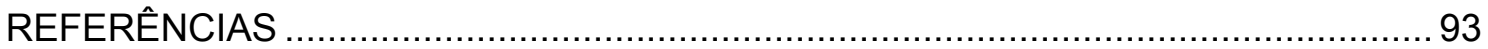

ANEXO - MEMÓRIA DE CÁLCULO 
FIGURA 1: EIXO NORTE-SUL NO SEU SURGIMENTO 19

FIGURA 2: EIXOS ESTRUTURAIS. 20

FIGURA 3: VISTA PARCIAL DA CIDADE DE CURITIBA 21

FIGURA 4: FEIRINHA DO LARGO DA ORDEM NO SETOR HISTÓRICO 22

FIGURA 5: ESQUEMA BÁSICO DA REDE DE TRANSPORTE COLETIVO. 23

FIGURA 6: SISTEMA DE TRANSPORTE PÚBLICO DE CURITIBA EM SUA INAUGURAÇÃO, NO ANO DE 1974 24

FIGURA 7: DISTRIBUIÇÃO DOS EIXOS ESTRUTURAIS EM CURITIBA 25

FIGURA 8: EIXO NORTE-SUL, COM CANALETA EXCLUSIVA 26

FIGURA 9: OBRAS DE IMPLANTAÇÃO DA LINHA VERDE 27

FIgURA 10: LOCALIZAÇÃO DE INTEGRAÇÃO DO TRANSPORTE PÚBLICO COM DEFINIÇÃO DE SUA CLASSIFICAÇÃO 30

Figura 11: TERminaIS DE PONTA (TERMINAL PINHEIRINHO E TERMINAL BOQUEIRÃO) ....... 31

FIgURA 12: TERMINAIS INTERMEDIÁRIOS (TERMINAL PORTÃo E TERMINAL CABRAL)..........31

Figura 13: TERminal CENTRAL (PRAÇA RUI BARBOSA) 32

FIgURA 14: ESTAÇÕES TUBO NO CORREDOR NORTE-SUL. 32

FIGURA 15: COMBINAÇÕES DOS DADOS PARA DISPONIBILIDADE (CURTO, MÉDIO E LONGO PRAZO) E QUALIDADE (ALTA, MÉDIA E BAIXA) 
FIGURA 16: DADOS GEOGRÁFICOS: EQUIPAMENTOS DE EDUCAÇÃO E LAZER E ÁREAS DE INVASÃO

FIGURA 17: DADOS GEOGRÁFICOS: SISTEMA DE TRANSPORTE PÚBLICO

FIGURA 18: CÁLCULO DO INDICADOR ACESSIBILIDADE AO TRANSPORTE PÚBLICO 46

FIGURA 19: DESEMPENHO DOS DOMÍNIOS DO IMUS 56

FIGURA 20: DESEMPENHO DOS INDICADORES NO CÁLCULO DO IMUS .58

FIGURA 21 DISTRIBUIÇÃO DAS REGIONAIS EM CURITIBA 71

FIGURA 22: GRÁFICO COMPARATIVO DO IMUS REGIONAL PELA DENSIDADE DEMOGRÁFICA DE CADA REGIONAL 76

FIGURA 23: FRAGMENTAÇÃO URBANA. 79

FIGURA 24: COBERTURA DA REDE DE TRANSPORTE PÚBLICO 81

FIGURA 25: VALORES CALCULADOS PARA OS DOMÍNIOS DO IMUS COMPARADO PARA SÃO CARLOS E CURITIBA .84 
TABELA 1: ESTRUTURA DO IMUS 34

TABELA 2: DISTRIBUIÇÃO DOS PESOS. 39

TABELA 3: AVALIAÇÃO DA DISPONIBILIDADE E QUALIDADE DOS DADOS PARA O CÁLCULO DOS INDICADORES PARA A CIDADE DE CURITIBA 50

TABELA 4: INDICADORES DO IMUS QUE NÃO FORAM CALCULADOS EM CURITIBA 53

TABELA 5: RESULTADOS DO IMUS GLOBAL E SETORIAL 53

TABELA 6: SIMULAÇÕES PARA INDICADORES NÃO CALCULADOS 54

TABELA 7: DESEMPENHO DOS INDICADORES NO CÁLCULO DO IMUS. 59

TABELA 8: INDICADORES ORDENADOS POR PESOS ACUMULADOS, EM CURITIBA 62

TABELA 9: COMPARAÇÃO ENTRE PESOS ACUMULADOS E SCORES DOS INDICADORES 66

TABELA 10: INDICADORES UTILIZADOS PARA O CÁLCULO DO IMUS REGIONAL .72

TABELA 11: Resultados PARA os CÁlCULOS REgIONAIS EM CURITIBA 73

TABELA 12: DENSIDADE POPULACIONAL POR REGIONAL 75

TABELA 13: RESUltAdos do IMUS GLOBAL E SETORIAL PARA SÃo CARLOS E CURITIBA. 83

TABELA 14: INDICADORES NÃO CALCULADOS EM SÃO CARLOS E CURITIBA .83

TABELA 15: Resultados do IMUS GLOBAL E SETORIAL COMPARATIVO PARA SÃo CARLOS E CURITIBA 84 
MIRANDA, H. F. (2010). Mobilidade urbana sustentável e o caso de Curitiba. Dissertação (Mestrado) - Escola de Engenharia de São Carlos, Universidade de São Paulo, São Carlos, 2010.

O atual modelo de planejamento dos transportes é constantemente confrontado com novos ideais associados à mobilidade sustentável. Assim, inúmeros pesquisadores debruçam-se em busca de indicadores e índices capazes de avaliar e monitorar o desempenho de políticas públicas relacionadas ao tema. Dessa forma foi desenvolvido o Índice de Mobilidade Urbana Sustentável (IMUS), uma ferramenta pautada nos preceitos da mobilidade sustentável com a proposta de tornar-se um apoio à gestão municipal. Por ser um método recente, sua aplicação ainda é limitada. Assim, o objetivo deste estudo concentra-se em realizar o cálculo do índice na cidade de Curitiba, muito conhecida por suas soluções urbanas que associam o planejamento dos transportes ao uso do solo. A aplicação do método na cidade fundamentou-se não apenas em obter o simples score relacionado ao desempenho das condições da mobilidade local, mas também possibilitaram avaliar o próprio método. $O$ valor resultante alcançado foi correspondente a 0,747 , confirmando Curitiba como uma cidade com características bastante positivas quanto às políticas urbanas voltadas à mobilidade. Por outro lado, foram identificadas algumas deficiências, especialmente quanto aos modos não motorizados de transporte. O cálculo do IMUS permitiu encontrar também indicadores que não foram capazes de identificar aspectos reconhecidamente favoráveis da cidade, demonstrando que possivelmente esses apresentem problemas de avaliação ou normalização de valores. A aplicação do método também se mostrou eficiente para promover uma avaliação intraurbana entre as diversas regiões da cidade. Nesse aspecto Curitiba demonstrou um saudável equilíbrio, sem apresentar grandes disparidades quanto suas políticas locais. Tal característica mostra-se bastante favorável para identificar Curitiba como um benchmarking da mobilidade sustentável. Finalmente o método foi testado como uma ferramenta de comparação entre cidades distintas, demonstrando também ser eficiente, desde que se mantenha uma estrutura de cálculo compatível entre as cidades que se deseja comparar.

Palavras-chave: mobilidade urbana sustentável, indicadores urbanos, indicadores de mobilidade, índice de mobilidade urbana sustentável, planejamento da mobilidade, Curitiba. 
MIRANDA, H. F. (2010). Sustainable urban mobility and the case of Curitiba. M.Sc. Dissertation - Escola de Engenharia de São Carlos, Universidade de São Paulo, São Carlos, 2010.

The current transportation planning approach is constantly confronted with new values derived from the concept of sustainable mobility. As a consequence, several researchers have devoted time and effort in the search of indicators and indexes capable of evaluating and monitoring the performance of urban policies related to the theme. The Sustainable Urban Mobility Index (I_SUM) was one of them. It is a decision support tool developed to help municipal administrations in the planning and management of sustainable mobility. As it is a recent method, its application is still limited to just a few cases. The objective of this study is to conduct an application of the index in Curitiba, which is a well-known city due to the quality of its urban planning solutions that associate transport planning to land use. The application of the method in the city was motivated not only by the possibility of having a score showing the performance of the city regarding sustainable mobility, but also by the opportunity of evaluating the method itself. The overall resulting value was 0.747 , what confirms that Curitiba has very positive characteristics and effective urban policies regarding sustainable mobility. Conversely, some deficiencies were identified, especially concerning non-motorized transport modes. The I_SUM calculation also allowed the identification of indicators that were not able to identify aspects that are good to the city. That may suggest problems in the assessment or normalization procedures of the index. The method application was also efficient for the evaluation of city subdivisions. Curitiba also performed well in that intra-urban evaluation, with a positive equilibrium of the values throughout the city. It may be an indication that the city policies are homogeneously applied in the entire urban area, what certainly contributes to characterize Curitiba as a benchmark of urban mobility. Finally, when used to compare distinct cities, the method was also efficient. In that case, the calculation was compatible with a structure adjusted to simultaneously represent the compared cities.

Keywords: urban sustainable mobility, urban indicators, mobility indicators, index of sustainable urban mobility, mobility planning, Curitiba. 



\section{INTRODUÇÃO}

Nesta seção faz-se uma breve caracterização do problema estudado considerando a importância da existência e aplicação de um índice que avalie a mobilidade urbana sustentável nas cidades, bem como a necessidade de se encontrar um referencial de excelência que possa inspirar gestores na criação de políticas públicas. Em seguida são apresentados a justificativa, o objetivo e também a estrutura de todo o trabalho.

\subsection{Caracterização do Problema}

Problemas relacionados ao deslocamento de pessoas e bens no espaço urbano existem desde o surgimento das cidades, mas esses se tornaram mais graves com seu crescimento desenfreado. Buscando melhor compreender tal problemática e também como saná-la, muitos pesquisadores têm trabalhado na busca de métodos adequados para avaliação dos impactos dos modos de transporte sobre a sociedade. Não apenas isso, mas principalmente em como a mobilidade urbana pode alcançar o status da sustentabilidade.

O desenvolvimento de um método único de avaliação para todas as cidades, como um índice capaz de monitorar o desempenho e efetividade das políticas públicas, tornouse um desafio para pesquisadores do mundo todo. Entre todos os debates sobre o tema, observou-se que um ferramental para avaliar a mobilidade sustentável deveria contemplar questões essenciais relacionadas aos aspectos sociais, econômicos e também ambientais.

Considerando tais premissas, Costa (2008) desenvolveu o IMUS - Índice de Mobilidade Urbana Sustentável, com a proposta de oferecer uma metodologia capaz de avaliar quantitativamente muitos dos aspectos pertinentes à mobilidade, incluindo os cenários essenciais já citados (social, econômico e ambiental). 
Com uma estrutura complexa, composta por 87 indicadores, o IMUS não é uma ferramenta propriamente simples de ser aplicada, mas que agrega aspectos pertinentes aos vários tamanhos de cidade. Tecnicamente qualquer padrão urbano pode ser avaliado por ele, resta saber se o julgamento obtido corresponderá à situação real demonstrada pelo município submetido ao método.

Tal dúvida deve-se ao fato de que o índice, elaborado recentemente, ainda foi pouco aplicado, sendo necessário assim ser submetido a outras avaliações. Ele deve ser utilizado em municípios com características variadas, permitindo a verificação de sua eficácia como ferramenta de controle do monitoramento das políticas públicas.

\subsection{Justificativa}

A necessidade de encontrar um método padrão para avaliação da mobilidade urbana e seu grau de sustentabilidade motivou o desenvolvimento do IMUS - Índice de Mobilidade Urbana Sustentável. Sua estrutura, composta por 87 indicadores, abrange os mais diversos temas relacionados à mobilidade, considerando seu planejamento, execução e gestão.

Sendo uma ferramenta recente, a aplicação do IMUS ainda é limitada. Apenas São Carlos (município no estado de São Paulo) e, mais recentemente, Brasília tiveram seu cálculo concluído. Porém o índice deve ser propagado a outras cidades, não apenas para promover gestão da mobilidade sustentável, mas principalmente para formalizar uma análise de desempenho e efetividade das políticas desenvolvidas.

A aplicação continuada do IMUS permite criar cenários de evolução da mobilidade urbana em qualquer cidade que faça uso do método. Essa característica torna-se um facilitador a qualquer gestor que deseje comparar o desempenho local frente às políticas empreendidas. Mas ele vai além, promovendo comparações de desempenho entre cidades distintas. Tal qualidade dá margem a outra questão essencial: a identificação de um modelo de cidade com alto desempenho no que diz respeito à mobilidade sustentável, o chamado benchmarking. 
A aplicação do método em uma cidade reconhecida como um modelo em mobilidade permite ir além da simples definição de um referencial, ela possibilita a avaliação do próprio método. Isso se deve ao fato de que características positivas precisam ser reconhecidas pelo índice. Caso isso não aconteça, é possível que o IMUS não consiga identificar suas qualidades. A situação inversa também deve ser avaliada, com circunstâncias consideradas negativas. É preciso verificar se essas são realmente desfavoráveis à mobilidade. Tal exercício permite investigar o desempenho não apenas da cidade escolhida como potencial referência, mas a própria ferramenta que Ihe proporciona tal status.

\subsection{Objetivo}

O objetivo principal deste trabalho é avaliar o IMUS como ferramenta de análise da mobilidade sustentável, identificando possíveis falhas de julgamento no método de cálculo de seus indicadores. O estudo ainda permitirá considerar o índice como instrumento de planejamento e gestão da mobilidade urbana, indicando aspectos positivos e negativos da cidade estudada, através do desempenho de cada indicador calculado.

A avaliação do método é dada pelo cálculo do IMUS em uma cidade de alto padrão de mobilidade, sendo essa a cidade de Curitiba, muito conhecida por soluções urbanas que aliam o transporte público ao uso do solo. Tal condição sugere a cidade como um possível benchmarking da mobilidade sustentável.

Assim, espera-se avaliar a própria cidade de Curitiba quanto à mobilidade, considerando suas escolhas de planejamento e execução de suas políticas públicas. Mas esse estudo vai além, objetivando ainda promover uma avaliação da mobilidade intraurbana na capital paranaense, através da aplicação do índice em diversas regiões da cidade.

Esse trabalho visa também promover uma análise do índice como método de comparação de desempenho entre cidades distintas. Tal condição permite confrontar 
diferentes políticas e seus resultados, favorecendo a promoção do aprendizado através do reflexo de boas práticas de gestão.

\subsection{Estrutura do Trabalho}

Este documento é composto por seis capítulos estruturados da seguinte forma: uma introdução ao tema de pesquisa, sendo essa a seção atual. A próxima seção aborda questões relacionadas à mobilidade urbana e a inserção do tema da sustentabilidade associado à mesma. Além disso, discute a criação de indicadores para sua avaliação e a importância da definição de um benchmarking de mobilidade sustentável. 0 capítulo seguinte apresenta a cidade de Curitiba, considerada um modelo no desenvolvimento de políticas para a mobilidade, contemplando seu processo de planejamento do uso do solo associado ao transporte público.

Posteriormente é apresentado o método proposto para o desenvolvimento desse trabalho, incluindo a própria metodologia do IMUS e questões específicas tratadas nesse estudo. Em seguida, todos os resultados obtidos são detalhados, avaliando-se o desempenho do próprio método, bem como da cidade a ele submetida. Finalmente são apresentadas as conclusões obtidas, assim como sugestões para o desenvolvimento de trabalhos futuros. O documento contempla ainda as referências utilizadas no processo de desenvolvimento desse estudo e, mais além, são apresentados os anexos com o memorial de cálculo do IMUS para a cidade de Curitiba. 


\section{MOBILIDADE URBANA SUSTENTÁVEL}

Este capítulo contempla um breve resumo a respeito de teorias sobre sustentabilidade associada à questão da mobilidade, dando ênfase à utilização de indicadores no processo de planejamento e monitoração das políticas públicas, buscando maior eficiência pela administração municipal. Em seguida é apresentado o IMUS como ferramenta de análise da mobilidade urbana, considerando a necessidade de avaliação de seu desempenho, aplicando-o em uma cidade considerada referência quanto ao tema em questão.

\subsection{Sustentabilidade e Mobilidade}

Os problemas relacionados ao transporte são bastante antigos para nossa sociedade e suas deficiências provêm tanto de escolhas históricas, como a falta de planejamento e investimentos, quanto atuais, decorrentes da extrema dependência dos meios motorizados (RODRIGUES DA SILVA et al., 2008).

Litman (1999) afirma que os sistemas de transporte hoje implantados oferecem muitos benefícios, mas também causam muitos problemas. Eles servem mal a todas as pessoas que realizam suas viagens em modos não motorizados e distribuem os custos e benefícios de forma desigual. Também se mostram financeiramente onerosos para as famílias, governos e empresas, além de serem cada vez menos eficazes, devido aos congestionamentos de tráfego e usos do solo dispersos, e uma das principais causas de morte e invalidez. Eles ainda contradizem todas as teorias de conservação ambiental e qualidade de vida, pois estão baseados em recursos não renováveis que podem se tornar escassos no futuro.

Assim, diversos estudos têm sido promovidos com o intuito de melhor compreender a realidade da mobilidade nas cidades e revertê-la em um cenário mais favorável que compreenda os conceitos de sustentabilidade. 
Sustentabilidade é uma palavra bastante presente na atualidade, podendo ser considerada um conceito recente que coloca a sociedade em reflexão sobre suas opções de consumo. No entanto, esse não é um termo tão recente quanto parece, pelo contrário, ele já vem sendo discutido há muitos anos. Em 1987, a Comissão Mundial de Meio Ambiente e Desenvolvimento definiu, em seu Relatório de Meio Ambiente, desenvolvimento sustentável como "aquele que atende às necessidades da geração atual sem pôr em risco a capacidade das gerações futuras de atender às suas próprias necessidades". Essa definição explica, por exemplo, a necessidade de controle sobre a emissão de gases ou o esgotamento de recursos, questões que são de interesse global.

Discussões mais recentes sobre sustentabilidade consideram que, enquanto alguns dos problemas surgem em nível nacional, ou global, outros são predominantemente locais (MAY; CRASS, 2007). As emissões de gases tóxicos, por exemplo, afetam o planeta como um todo, sem respeitar fronteiras políticas. Porém, a quantidade de gases que cada cidade emite interfere diretamente sobre a qualidade de vida de sua população, como as grandes metrópoles que sufocam seus moradores com a imensa quantidade de poluentes lançados diariamente pela frota de veículos motorizados.

Tal problemática tem aproximado as discussões sobre sustentabilidade do cidadão comum, proporcionando uma visão ecológica mais próxima da sociedade e introduzindo um novo questionamento aos hábitos populares. Organizações não governamentais (ONGs) tentam introduzir a população nesse grande debate utilizando-se de ferramentas simples, como a difusão do conceito de "Pegada Ecológica", que indica a quantidade de recursos naturais gastos para sustentar suas atividades diárias (WWF, 2010).

Uma definição interessante de sustentabilidade é aquela dada por Litman (2009), que introduz a sustentabilidade como uma preocupação com os impactos sobre o consumo de recursos e seu reflexo em longo prazo. O autor afirma que: "se a qualidade e equidade são preocupações ecológicas, não faz sentido ignorar tais impactos sobre a geração atual. Assim, a sustentabilidade pode ser definida como o planejamento que considera todos os impactos, incluindo aqueles distantes no tempo e no espaço". Assim, o planejamento sustentável é visto como um reflexo das preocupações sobre os riscos, a longo prazo, do consumo de recursos correntes, refletindo os objetivos de equidade intergeracional (sendo justo com as futuras gerações) e integridade 
ecológica. O autor ainda completa que o planejamento sustentável deve ser reflexo de uma percepção sobre objetos e seus impactos, interagindo frequentemente, de forma que as soluções vislumbradas devem refletir em análises integradas. $E$ isso também pode ser aplicado para o planejamento de transporte, atualmente repensado como um conceito mais abrangente: a mobilidade.

O tema da mobilidade pode ser considerado relativamente recente. Em geral os municípios sempre deram atenção aos sistemas de transporte relacionados ao tráfego e circulação, ao transporte público e à infraestrutura. Tal prática de certa forma justifica os problemas hoje verificados não apenas no Brasil, mas no mundo todo, quanto ao deslocamento de pessoas e bens nas cidades. Miranda et al. (2009) afirmam que, por ser recente, ainda é comum associar-se o conceito de mobilidade somente ao transporte, sobretudo aos modos motorizados. Restringe-se nesse caso, de forma equivocada, praticamente apenas à circulação de automóveis e ao uso de transporte coletivo.

$\mathrm{Na}$ maioria dos países, incluindo o Brasil, os problemas de locomoção enfrentados diariamente no meio urbano são com frequência objeto de uma análise fragmentada, que dissocia o sistema de transporte público, circulação de veículos particulares e uso do solo (BOARETO, 2008). Porém, o conceito de mobilidade é mais abrangente, adotando uma visão sistêmica sobre toda a movimentação de bens e de pessoas, e envolvendo todos os modos e todos os elementos que produzem as necessidades desses deslocamentos (BRASIL, 2007). Isso representa uma necessidade de atingir eficiência na gestão pública, fato que levou o conceito de sustentabilidade a ser associado ao conceito de mobilidade. Por outro lado, por ser essencial às necessidades humanas, passou a relacionar conceitos como a gestão participativa e a sustentabilidade ambiental. Estes ampliaram sua significação, transformando-o em parâmetro para utilização de vias e espaços urbanos de forma eficiente e dinâmica, com a minimização dos impactos negativos (RODRIGUES DA SILVA et al., 2008). 


\subsection{Mobilidade Urbana Sustentável}

O planejamento convencional tende a assumir que o progresso de transporte é linear, indo do modo mais antigo e lento, ao mais atual e veloz. Esse modelo pressupõe que modos mais antigos não são importantes e assim, por exemplo, não há prejuízo se o aumento do tráfego de automóvel provoca atrasos e congestionamento do trânsito público ou cria uma barreira para os pedestres. A mobilidade sustentável reflete um modelo paralelo, pressupondo que cada modo pode ser útil, esforçando-se para criar sistemas de transporte equilibrados, com o uso de cada modo destinado ao que ele faz melhor (LITMAN e BURWELL, 2006).

Black et al. (2002) afirmam que um adequado sistema de mobilidade urbana sustentável e de uso do solo deve assegurar o acesso a bens e serviços de maneira eficiente para todos os habitantes da área urbana, proteger o meio ambiente, o patrimônio cultural e os ecossistemas para a presente geração sem, no entanto, limitar as oportunidades das gerações futuras. May e Crass (2007) vão mais além e determinam as seguintes ações para a obtenção de um sistema de transportes sustentável:

- Fornecer acesso às necessidades básicas da população;

- Assegurar a saúde humana e do ecossistema;

- Promover a equidade, tanto para a geração atual quanto para as sucessivas gerações;

- Ser acessível, equitativo e eficaz;

- Oferecer escolhas quanto ao modo de transporte;

- Suportar uma economia competitiva e equilibrada;

- Limitar as emissões de resíduos;

- Utilizar taxas de recursos que permitam sua renovação ou substituição;

- Minimizar os impactos sobre o uso do solo e a geração de ruídos.

Banister (2007) define que uma abordagem voltada à mobilidade sustentável exige ações para redução da necessidade de viagens, diminuindo suas distâncias e incentivando maior eficiência do sistema de transportes. Um planejamento de transporte mais sustentável apoia a redução da dependência do automóvel (definida 
pela utilização do automóvel em níveis muito elevados, orientação do uso do solo, e falta de alternativas nas viagens), já que a dependência do automóvel impõe vários custos econômicos, sociais e ambientais.

No entanto, existem argumentos que estabelecem que os benefícios proporcionados pelos automóveis superam esses custos, que os problemas podem ser resolvidos com o pensamento voltado para melhorias técnicas. Afirmam ainda que as alternativas (tais como transporte público) são mais prejudiciais, e que a dependência do automóvel é inevitável) (GREEN, 1995). Além disso, algumas pesquisas sugerem que as várias distorções no mercado contribuem para a dependência excessiva do automóvel e dos projetos de veículos que são mais poluentes e perigosos que o ideal. Essas distorções incluem:

- Financiamentos específicos que incentivam a construção de estradas;

- Generosos estacionamentos e normas para a capacidade viária;

- Leis de zoneamento e práticas que favorecem o uso do automóvel, padrões de orientação do uso do solo;

- Excesso de recursos destinados à manutenção de vias e estacionamentos;

- Baixo custo do automóvel;

- Falta de alternativas de viagem e condições viárias desfavoráveis para pedestres e ciclistas.

Litman e Burwell (2006) afirmam que a redução de tais distorções de mercado pode ajudar a alcançar o objetivo de um sistema de transportes mais sustentável. Apesar de não ser fácil mudar a chamada "cultura do automóvel" para atingir um planejamento sustentável da mobilidade urbana, as decisões sobre o transporte individual devem estar subordinadas às estratégias comunitárias de longo prazo. Isso significa que devem ocorrer profundas modificações em nossos sistemas de transporte, de forma a aumentar sua eficiência econômica, social e ambiental (LITMAN, 1999).

As mudanças de planejamento devem partir, a princípio, dos gestores urbanos, afinal a decisão política tornou-se uma peça fundamental na construção da mobilidade sustentável. Os governos precisam dar maior ênfase tanto na identificação dos problemas atuais e futuros quanto em suas causas subjacentes, e também garantir que a população compreenda a natureza dos problemas a serem superados, bem como a necessidade de fazê-lo (MAY; CRASS, 2007). 
Uma única solução não será suficiente para resolver a maioria dos problemas enfrentados. Os governos devem basear suas estratégias em grupos de medidas eficazes, em que cada uma reforce os efeitos das demais (MAY; CRASS, 2007). Assim, é possível entender que medidas isoladas dificilmente atingirão o ideal da sustentabilidade. Somente a combinação de ações pode atingir a real efetividade, associando esforços mútuos de todos os atores urbanos: gestores, investidores e principalmente da sociedade em geral.

\subsubsection{Mobilidade urbana sustentável no Brasil}

A política urbana no Brasil apresenta uma história bastante recente, tendo sido efetivamente iniciada com a promulgação da Constituição Federal no ano de 1988. O país até então presenciava casos isolados da manifestação do interesse de municípios sobre as leis que regulam o espaço urbano. A grande mudança promovida pela nova constituição foi a menção, em seus artigos 182 e 183, da função social da cidade e da propriedade. Assim foi estabelecido o Plano Diretor como o instrumento básico da política de desenvolvimento e expansão urbana (BRASIL, 1988).

Anos mais tarde, foi aprovada a Lei Federal $n^{\circ} 10.257 / 01$, conhecida como Estatuto da Cidade, que regulamenta os artigos já citados da Constituição Federal e estabelece as diretrizes gerais da política urbana no Brasil. Prevendo ordenar o desenvolvimento das funções sociais da cidade e da propriedade, ela estabelece como responsabilidade do poder municipal a gestão sobre o planejamento urbano com a aplicação de instrumentos urbanísticos que prevejam a oferta de equipamentos comunitários, transporte e serviços públicos adequados aos interesses e necessidades da população e às características locais (BRASIL, 2001).

Porém, o estabelecimento de uma real política urbana participativa e a favor do cumprimento da função social da cidade e da propriedade encontra dificuldades em ser efetiva, pois muitos governos não estão preparados para lidar com o poder de decisão oferecido à sociedade. Souza (2003) afirma que muitos gestores, apesar de concordarem com o envolvimento da população, limitam-no a consultas e informações com conteúdos e posicionamentos já definidos. 
O mesmo problema é verificado com as questões relacionadas ao conceito de mobilidade urbana, pois ele ainda é bastante novo para o governo federal e para a maioria das cidades brasileiras (BOARETO, 2008). Isso se justifica pelo fato de que nem mesmo há uma política federal de mobilidade aprovada, pois o projeto de lei que trata do assunto em questão ( $P L n^{\circ}$ 1687/2007) tramita lentamente pelas esferas legislativas.

A nova lei, que institui as diretrizes da política de mobilidade urbana, estabelece como objetivo o acesso universal à cidade, por meio do planejamento e gestão do Sistema de Mobilidade Urbana. Ela também define o Sistema de Mobilidade Urbana como um conjunto organizado e coordenado dos meios, serviços e infraestrutura, garantindo o deslocamento de pessoas e bens na cidade.

De acordo com o projeto de lei em questão, os princípios fundamentais da Política Nacional de Mobilidade Urbana são:
I - Acessibilidade universal;
II - Desenvolvimento sustentável das cidades, nas dimensões social, econômica e ambiental;
III - Equidade no acesso dos cidadãos ao transporte público coletivo;
IV - Eficiência, eficácia e efetividade na prestação dos serviços de transporte urbano;
V - Transparência e participação social no planejamento, controle e avaliação da política de mobilidade urbana;
VI - Segurança nos deslocamentos das pessoas;
VII - Justa distribuição dos benefícios e ônus decorrentes do uso dos diferentes meios e serviços;
VIII - Equidade no uso do espaço público de circulação, vias e logradouros.

Considerando tais princípios estabelecidos, o projeto de lei confirma a proposta de Boareto (2008), que determina que uma política capaz de enfrentar os problemas urbanos deve ter como objetivo a reversão do atual modelo de mobilidade, priorizando instrumentos de gestão urbanística, princípios de sustentabilidade ambiental e inclusão social. A mobilidade urbana para a construção de cidades sustentáveis será produto de políticas que proporcionem o acesso amplo e democrático ao espaço urbano, priorizem os modos coletivos e não motorizados de transporte, eliminem ou 
reduzam a segregação espacial, contribuam para a inclusão social e favoreçam a sustentabilidade ambiental (BRASIL, 2007).

\subsection{Indicadores da mobilidade sustentável}

Planejamento, políticas ambientais e de controle são ferramentas fundamentais para a eficácia da mobilidade, mas nenhuma delas poderia ser realmente eficiente sem as informações relativas às condições atuais e desejáveis do espaço urbano. Um diagnóstico de qualidade é a base para qualquer gestor. No entanto, as informações necessárias para a identificação dos problemas e potencialidades nem sempre estão disponíveis. No geral, não existem métodos de avaliação que qualifiquem corretamente a mobilidade e seu grau de sustentabilidade.

Diversos autores têm estudado essa problemática do espaço urbano e assim apareceram sugestões como forma de compreender e possivelmente melhorar a condição atual. Gudmundsson (2001) apresenta algumas alternativas para reverter esse quadro: (1) entender a política de planejamento e seus procedimentos de regulação; (2) verificar a penetração do conceito de sustentabilidade nas políticas de planejamento e transporte; (3) verificar o reflexo das questões ambientais no planejamento dos transportes; (4) verificar como as questões de transporte refletem no desempenho ambiental; (5) verificar como a sustentabilidade não afeta o planejamento; (6) verificar o quanto a política ambiental foi definida como parte do desempenho do planejamento; (7) buscar as informações necessárias para verificar o desempenho do planejamento; (8) verificar a conexão entre o desempenho das propostas e as decisões políticas. Os procedimentos listados, se aplicados, podem garantir a sustentabilidade da mobilidade no espaço urbano, tão desejável no cenário atual.

Tais alternativas podem representar o que se chama de indicadores. Maclaren (1996) afirma que indicadores são simplificações de fenômenos complexos e Rodrigues da Silva et al. (2008) determinam que indicadores são úteis para descrever o comportamento de vários elementos e funções que formam o ambiente urbano. Assim, uma melhor imagem da condição analisada só é obtida através de uma combinação 
de indicadores, a fim de captar as diferentes dimensões e aspectos de qualquer problema particular (GUDMUNDSSON, 2001).

Litman (2009) estabelece que indicadores sejam selecionados e definidos para medir o progresso em direção a um objetivo específico. Eles podem refletir vários níveis de análise, como por exemplo: o progresso de decisão (qualidade de planejamento), as respostas padrões (viagens), os impactos físicos (emissões de gases e taxas de acidentes), efeitos sobre as pessoas e sobre o meio ambiente (ferimentos e mortes, danos ecológicos), além de seus impactos econômicos (custos sociais pela degradação ambiental).

Como Gudmundsson (2001) bem explicou, é preciso buscar informações que verifiquem o desempenho das decisões tomadas e suas consequências, pois assim um índice para a avaliação da mobilidade sustentável pode ser aplicado como ferramenta de controle e gestão da mobilidade sustentável.

Em vários países europeus, além de Canadá e Estados Unidos, diversos pesquisadores têm feito propostas para a criação de um índice que qualifique a mobilidade urbana nas cidades e avalie o seu grau de sustentabilidade. O que se sabe é que as características culturais de cada país podem interferir significativamente na construção desse índice, mas há um consenso sobre elementos fundamentais a serem analisados. Como colocam Steg e Gifford (2005), os temas chave para definir os indicadores de um transporte sustentável devem adequar-se aos aspectos ambientais, sociais e econômicos de uma sociedade.

Já existem indicadores tradicionais conhecidos para verificar a qualidade do transporte, mas esses consideram apenas as condições relacionadas ao tráfego motorizado (nível de serviço, velocidade média do tráfego, número de vagas em estacionamentos, acidentalidade). Além disso, esses indicadores tendem a contradizer os objetivos da mobilidade sustentável (LITMAN e BURWELL, 2006), uma vez que se preocupam tão somente com os modos motorizados de transporte.

A avaliação geral da sustentabilidade requer considerações sobre impactos nas esferas econômicas, sociais e ambientais, equilibrada por necessidades práticas e restrições. Assim, os tomadores de decisões devem selecionar conjuntos de 
indicadores que reflitam tanto as necessidades de sua comunidade como suas prioridades (LITMAN, 2009).

É essencial compreender que indicadores devem ser usados para conhecer perspectivas e limitações do planejamento. Assim, Litman (2009) estabelece que o uso de indicadores seja somente um passo no processo de planejamento global, uma vez que esse inclui tantas etapas, como: consultas aos usuários, definição dos problemas, estabelecimento de metas e objetivos, identificação e avaliação de opções, desenvolvimento de políticas e planos, implementação de programas, estabelecimento de metas de desempenho e medição de impactos. Ou seja, atingir os objetivos pretendidos requer esforços combinados de diversos grupos da sociedade em diversos momentos, como planejamento, execução e avaliação dos resultados.

\subsubsection{IMUS - Índice de Mobilidade Urbana Sustentável}

Considerando que indicadores são úteis para o processo de planejamento, é possível identificá-los como importantes ferramentas de análise das condições de mobilidade. Ainda podem ser úteis para comparar o desempenho entre cidades distintas, o que demonstra ser de grande valia para medir a evolução das boas práticas municipais (MIRANDA et al., 2009). Segundo TRB (2008), “(..) Uma diversidade de indicadores são usados, alguns dos quais particularmente apropriados e proveitosos para o planejamento e análise de políticas. Seria altamente desejável que as instituições de transportes desenvolvessem um conjunto padrão de indicadores básicos, com definições e métodos de coleta consistentes, apropriados para comparar impactos e tendências entre diferentes organizações, jurisdições e períodos do tempo. Isso poderia envolver alguns indicadores apropriados para todas as situações e outros para necessidades e condições específicas".

Considerando tal necessidade foi desenvolvido o Índice de Mobilidade Urbana Sustentável - IMUS (COSTA, 2008), com o objetivo de se tornar uma ferramenta efetiva de planejamento do transporte urbano.

Segundo Costa (2008), o IMUS é uma ferramenta para avaliação da mobilidade urbana capaz de revelar as condições atuais e medir os impactos de medidas e estratégias visando a mobilidade sustentável. Sua composição é dada por nove 
Domínios, distribuídos em 37 Temas e 87 Indicadores. Tal estrutura inclui tanto questões tradicionais quanto as relacionadas ao novo paradigma da mobilidade sustentável, possuindo a essencial qualidade de se adaptar a qualquer realidade urbana, graças à sua composição diversificada.

A aplicação destas avaliações nas cidades possibilita a identificação de fatores críticos e de maior impacto para a melhoria de aspectos globais e setoriais da mobilidade urbana, fornecendo subsídios para a proposição de políticas e estratégias visando à mobilidade sustentável (COSTA, 2008).

A avaliação dos indicadores dá-se através de um sistema de pesos que os qualifica de forma individual e também em grupo, possibilitando reconhecer a contribuição relativa de cada elemento para todo o sistema. Essa qualidade permite que o índice seja utilizado tanto para a formulação de políticas integradas ou direcionadas da mobilidade, favorecendo uma aplicação mais racional e eficiente de recursos.

A aplicação de tal método nas cidades de São Carlos, no interior do estado de São Paulo, e em Brasília, capital federal, revelou condições bastante distintas. Costa (2008) define que a aplicação do IMUS em São Carlos possibilitou a identificação de fatores críticos e de maior impacto para a melhoria de aspectos globais e setoriais da mobilidade urbana, fornecendo subsídios para a proposição de políticas e estratégias visando a mobilidade sustentável. O resultado obtido $(0,56$, em uma escala que vai de zero a um, em que zero é muito ruim e um é muito bom) revelou que a cidade apresentou um índice com valor razoável, mas capaz de ser melhorado. Em Brasília, os resultados demonstraram que o modelo de planejamento estabelecido por teóricos modernistas não consideraram valores globais de mobilidade urbana. O valor obtido para o IMUS atingiu 0,31, definido por Pontes (2010) como muito baixo e tendo seus pontos críticos relacionados às diretrizes de ocupação urbana instituída ao longo dos anos em planos e projetos.

O IMUS é uma ferramenta que demonstra possuir abrangência para considerar todos os fatores que influenciam no espaço urbano, pois sua estrutura agrega indicadores que tratam dos mais diversos temas.

López-Lambas, et al. (2010) afirmam que a produção de um conjunto homogêneo de indicadores que permite a monitoração rigorosa do planejamento utilizando métodos 
comuns é de grande importância, bem como o desenvolvimento de técnicas adequadas de avaliação que irão permitir que as gestões aprendam com as experiências desenvolvidas por outros. Nesse caso, o reconhecimento de um referencial em planejamento é bastante útil para fornecer parâmetros de comparação entre cidades, o chamado benchmarking.

Benchmarking é tradicionalmente entendido como um método para comparar os desempenhos de organizações ou processos simples, a fim de aprender com os melhores executantes e, assim, melhorar $o$ desempenho dos demais (GUDMUNDSSON, 2004). Dessa forma, encontrar uma cidade que seja um benchmarking na aplicação do IMUS é essencial, não apenas para se tornar uma referência às demais, mas também para submeter o método a uma avaliação de desempenho.

Considerando as cidades brasileiras, Curitiba sempre se destacou por suas soluções de transporte integradas ao planejamento de uso do solo. Mitchell (2008) afirma que uma metrópole depende de duas coisas básicas para funcionar: um bom planejamento de uso do solo, somado a um sistema de transporte eficiente. $E$ tais qualidades sempre foram associadas à capital paranaense. Assim, a cidade parece reunir condições para tornar-se um benchmarking quanto à mobilidade urbana nacional.

A história de seu planejamento, bem como as soluções urbanísticas que a tornaram conhecida são apresentadas no próximo capítulo, que tem como objetivo mostrar que soluções não são criadas repentinamente, mas são fruto de longos anos de planejamento contínuo e integrado. 


\section{CURITIBA E SUAS SOLUÇÕES URBANAS}

Este capitulo apresenta um breve histórico do processo de planejamento na cidade de Curitiba, destacando a associação entre soluções de uso e ocupação do solo com o sistema de transporte público, características que se tornaram a marca registrada da cidade pelo mundo todo.

\subsection{Planejamento Urbano}

Se Brasília tornou-se conhecida mundialmente por colocar em prática os conceitos desenvolvidos pelos Congressos Internacionais de Arquitetura Moderna, chamados de CIAM (GUTIÉRREZ, 2007), e expressou ao máximo a segregação espacial baseada na funcionalidade das áreas da cidade, Curitiba também foi outra cidade brasileira a ganhar destaque por suas soluções urbanas. Diferente da primeira, ela não procurou se moldar artificialmente, mas adaptar seu crescimento à racionalização do espaço público, utilizando o planejamento como um indutor do desenvolvimento (GNOATO, 2006).

Esse processo teve início muito antes do que muitos imaginam, em meados dos anos 1940, com a vinda para o Brasil do arquiteto francês Alfred Agache. Em sua passagem pela América do Sul, Agache deixou diversos planos diretores, como nas cidades de Porto Alegre, Rio de Janeiro e Buenos Aires, todos com características muito similares e que também refletiam um clássico desenho urbano presente nas cidades européias. Todos consideravam essencialmente um padrão de crescimento circular, baseado em anéis que expandem a cidade do centro para as periferias, assim como as cidades medievais, mas também com grandes avenidas rasgando o tecido antigo, como os bulevares estabelecidos por Eugène Haussmann em seu Plano para Paris (BENEVOLO, 2001; MUNFORD, 1998). 
Dessa forma a cidade conheceu uma organização baseada em centros funcionais (zoneamento), bem como a adoção de um Código de Edificações, implantado em 1953, e principalmente um novo desenho urbano conseguido através da implantação do Plano Massa na Rua XV, no centro da cidade, que consistiu na execução de galerias cobertas para ampliação do passeio de pedestres (GNOATO, 2006). Curitiba ainda possui traços desse plano, como algumas avenidas perimetrais e também seu centro cívico, disposto como um grande bulevar que une seu centro histórico ao poder jurídico e administrativo. É importante considerar que Agache não fez menção, em seu plano, a propostas para adensamento e verticalização.

A grande mudança verificada por Curitiba deve-se ao Plano Preliminar de Urbanismo, de 1965 (GNOATO, 2006), que pretendeu distanciar-se das grandes reformas urbanas aplicadas em cidades como São Paulo, identificadas no Plano Prestes Maia, que a rasgou com pontes e viadutos, ou também do modelo frio e desumano proposto pelos preceitos modernistas da Carta de Atenas, verificados em Brasília.

O principal responsável pela realização de tal plano foi Jorge Wilheim, com a participação de um grupo de jovens técnicos que vieram a se tornar importantes figuras para o cenário urbano brasileiro, como Luiz Forte Netto, Jaime Lerner, José Maria Gandolfi, Alfred Willer, entre outros, que ainda estiveram presentes na criação do curso de Arquitetura e Urbanismo da Universidade Federal do Paraná. Com uma nova postura projetual, Curitiba transformou a versão preliminar desse plano em lei já no ano de 1966 , com a lei municipal $n^{\circ} 2.828$, um ano após sua criação e também da fundação de um importante órgão de planejamento e projeto do espaço urbano: o IPPUC (Instituto de Pesquisa e Planejamento Urbano de Curitiba).

\subsubsection{Uso do solo}

O novo plano para a cidade demonstrava ênfase na distribuição de espaços e sua relação com a estrutura e infraestrutura dos edifícios e se transpôs para o urbanismo com a inter-relação entre zoneamento e transporte coletivo (GNOATO, 2003). Dessa forma Curitiba investiu esforços em expandir-se linearmente, contrapondo-se ao plano inicial de Agache (IPPUC, 2009). Assim, nas áreas centrais foi permitida a verticalização, mas perifericamente deviam ser respeitados os novos "Eixos Estruturais", que representavam a expansão das características do centro com 
comércio e verticalização, mas de forma ordenada e linear. O primeiro eixo foi o NorteSul, mostrado na Figura 1.

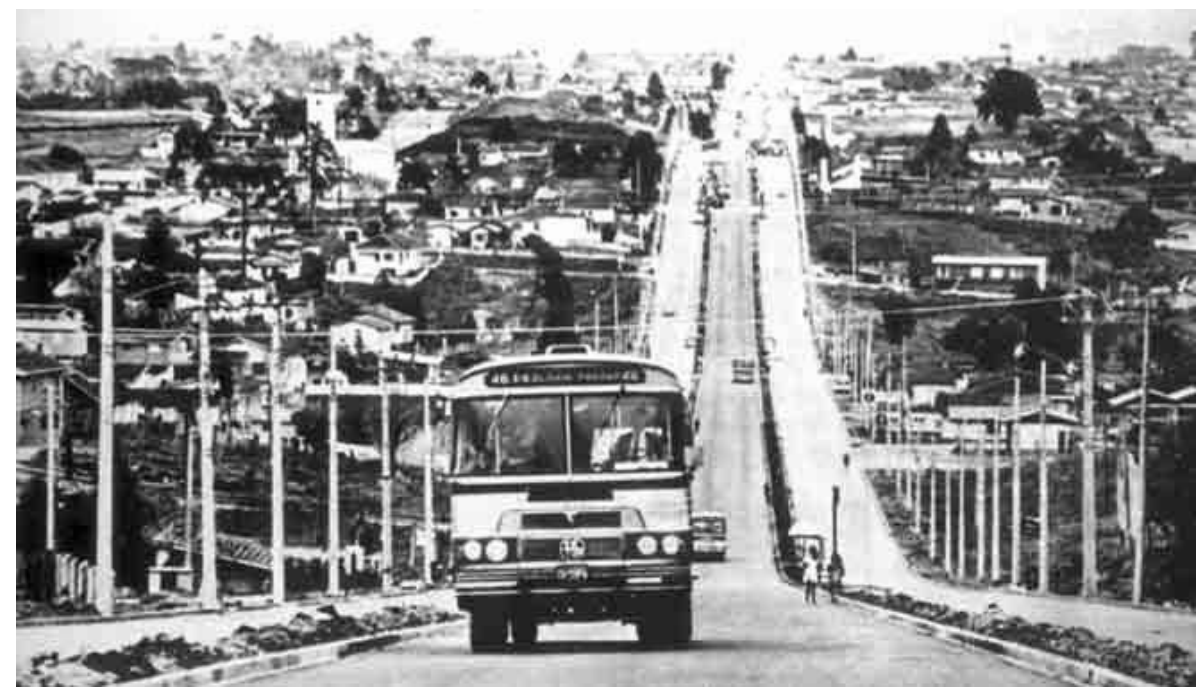

Figura 1: Eixo Norte-Sul no seu surgimento

Fonte: www.onibusdecuritiba.com.br, 2010

As grandes transformações urbanas da cidade deram-se com a posse de Jaime Lerner como prefeito no ano de 1971 (IPPUC, 2009). Assim evitou-se cair nos equívocos propostos pelo urbanismo modernista, como a segregação do tecido urbano determinada pelas atividades realizadas, presente no conceito da funcionalidade dos espaços preconizados por Le Corbusier (CHOAY, 2007). A influência das teorias urbanas de Jane Jacobs foi clara sobre os conceitos de urbanismo aplicados em Curitiba. Para a autora, quanto mais funções uma área possuir, mais segura essa será para sua comunidade: "uma rua viva sempre possui usuários e observadores" (JACOBS, 2007). Isso indica que funções distintas devem coexistir, atraindo as pessoas em tempo integral. Dessa forma os planejadores da cidade voltaram suas atenções para a transformação das ruas existentes, dando-lhes vida em todos os períodos do dia (GNOATO,2006).

O plano de Wilheim, continuado por Lerner, baseou-se num importante tripé: uso do solo, transporte coletivo e circulação (IPPUC, 2009). Seguindo tal exemplo, uma nova lei de zoneamento, datada de 1975, considerou o uso do solo e seus desdobramentos (coeficiente de aproveitamento e de altura dos edifícios) atrelados às concepções dos Eixos Estruturais e do sistema de transporte coletivo (GNOATO, 2006). Dessa forma, Curitiba obteve um importe êxito político e, com a mesma equipe de urbanistas 
atuando no IPPUC, garantiu o sucesso da implementação de seu plano com consecutivas administrações.

Os Eixos Estruturais (ver Figura 2) deram origem ao chamado sistema trinário, composto por um conjunto de três vias (daí o seu nome), sendo que a via central corresponde ao tráfego lento, abrigando o corredor de transporte público e o comércio local, e as vias externas destinam-se ao tráfego rápido, assim conhecidas como "Vias Rápidas".

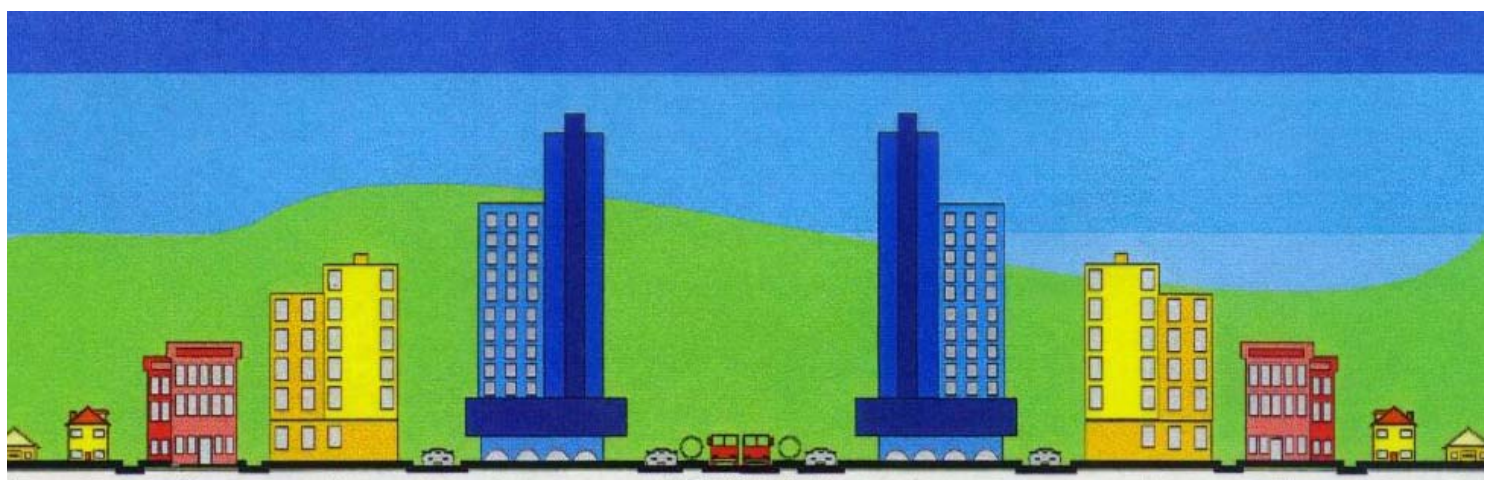

Figura 2: Eixos Estruturais

Fonte: PlanMob Curitiba, IPPUC, 2008

Os Eixos Estruturais correspondem ao clássico desenho urbano criado em Curitiba. Todo o zoneamento da cidade foi moldado conforme a distância que as regiões mantêm desses importantes referenciais de crescimento e adensamento populacional. Assim o próprio gabarito das edificações projeta-se de forma escalonar sendo o maior possível nos eixos e reduzindo conforme se distancia desses. Tal sistema e definição volumétrica dominam claramente a paisagem curitibana, como mostra a Figura 3. 


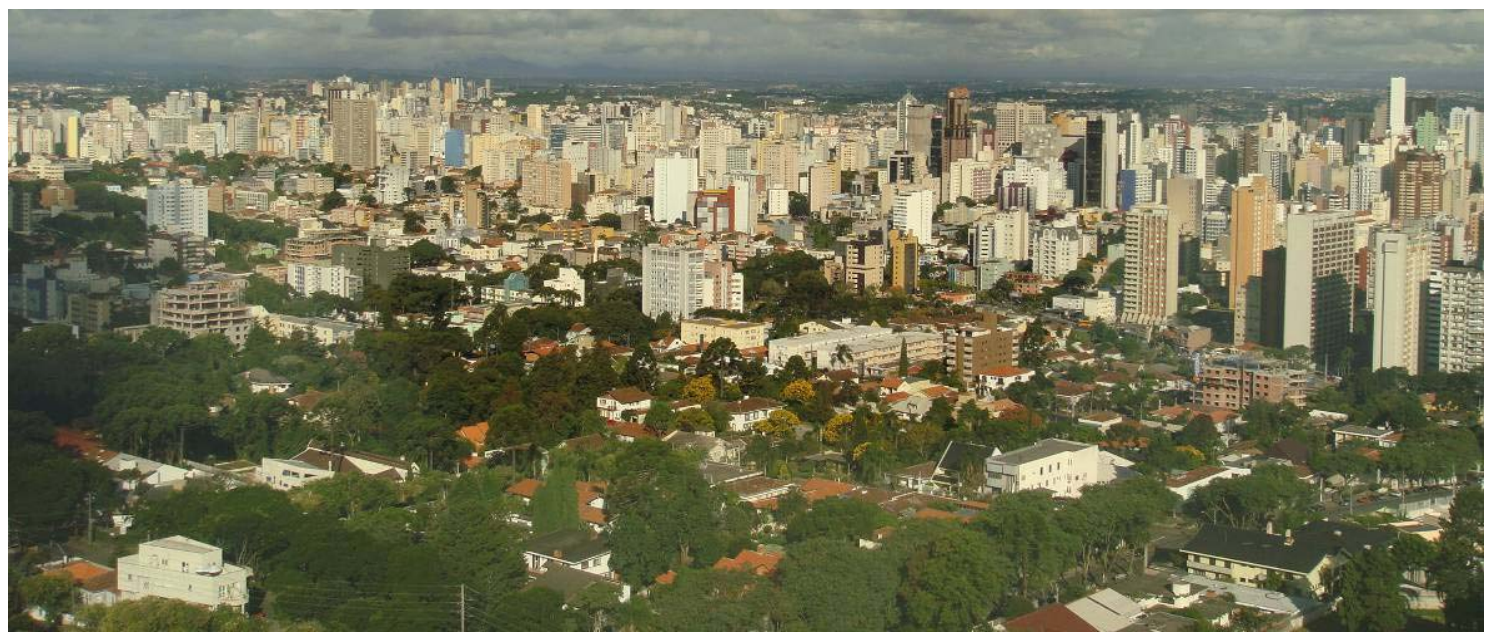

Figura 3: Vista parcial da cidade de Curitiba

Fonte: www.panoramio.com, 2010

Além das modificações verificadas na cidade pelas leis de uso e ocupação do solo, Curitiba dedicou parte de sua área central à circulação exclusiva de pedestres, com a criação de calçadões. O calçadão da Rua XV tornou-se o símbolo desse novo planejamento, e as vias preferenciais de pedestres corresponderam a um marco na transformação experimentada pela cidade no início da década de 1970 (IPPUC, 2008).

A intensa circulação de pedestres deu vida a esses locais, atraindo também formas de entretenimento para a população com a realização de feiras e atividades culturais ao ar livre. A Figura 4 mostra a tradicional Feirinha do Largo da Ordem. Realizada todos os domingos nas ruas do centro histórico da cidade, ela atrai uma grande quantidade de moradores e turistas. 


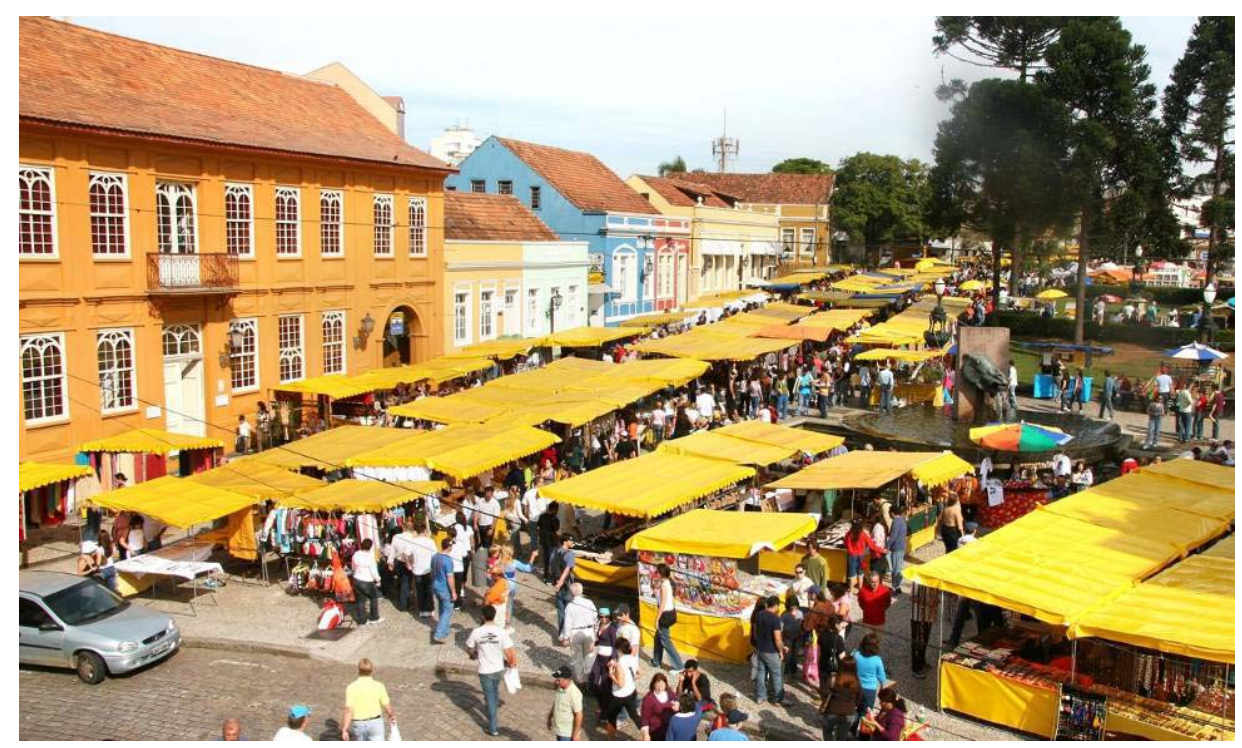

Figura 4: Feirinha do Largo da Ordem no Setor Histórico

Fonte: www.panoramio.com, 2010.

\subsection{Transporte público}

O documento de diagnóstico correspondente ao PlanMob Curitiba (IPPUC, 2008) define que o sistema de transporte coletivo da cidade fundamenta-se segundo conceitos básicos que estão em harmonia com seu planejamento. De acordo com o mesmo documento, as principais características podem ser identificadas a seguir e apresentadas esquematicamente pela Figura 5.

- Integração com o uso do solo e sistema viário, configurando uma cidade com crescimento linear, segundo os preceitos do Plano Diretor;

- Ampla acessibilidade com o pagamento de uma única tarifa;

- Prioridade do transporte coletivo em relação ao individual;

- Caracterização de corredores de transporte, com $72 \mathrm{~km}$ de canaletas, vias ou faixas exclusivas;

- Caracterização de uma rede integrada, pois os terminais de integração e algumas estações tubo facultam ao passageiro o uso de outras linhas sem pagamento de uma nova tarifa;

- Tipologia dos serviços definidos por ônibus com cores distintas;

- Terminais de integração fechados; 
- Terminais de integração nos bairros, para ampliar a integração fora dos eixos estruturantes;

- Abrangência metropolitana.

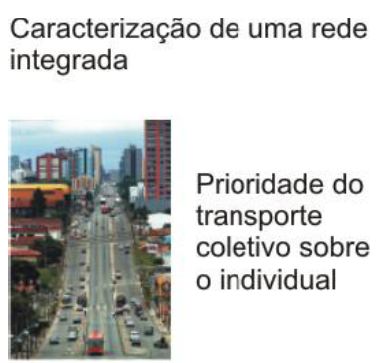

Ampla acessibilidade com o pagamento de uma única tarifa

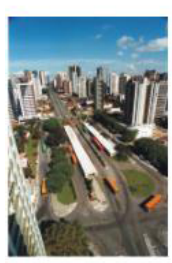

Terminais de

integração

fechados

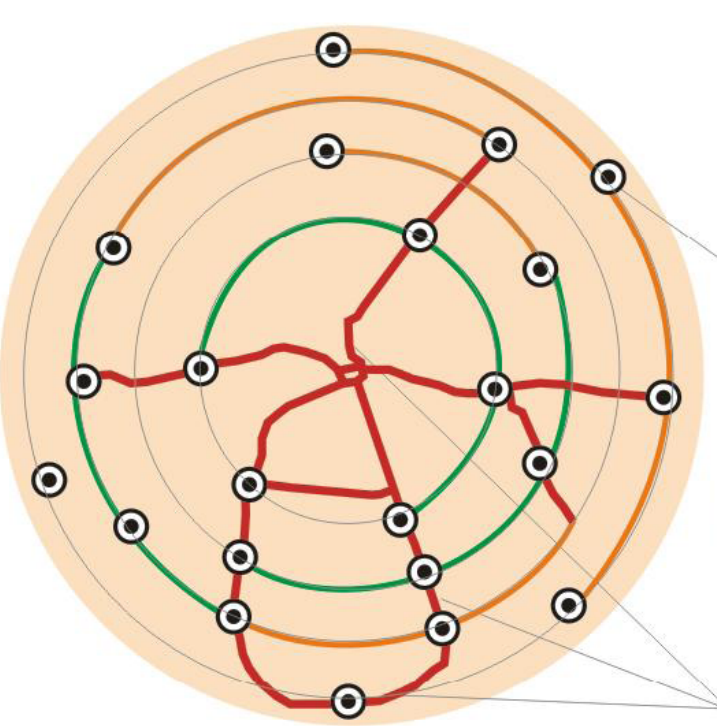

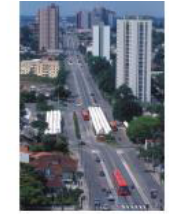

Terminais fora dos eixos ampliam a integração

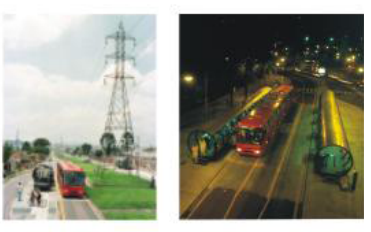

Caracterização de corredores de transporte com $72 \mathrm{~km}$ de canaletas, vias ou faixas exclusivas

Figura 5: Esquema básico da rede de transporte coletivo

Fonte: PlanMob Curitiba, IPPUC, 2008.

Tal conformação teve início no ano de 1974, quando o sistema começou suas operações (Figura 6). Nesse período ele contava com duas linhas expressas, oito linhas alimentadoras e dois terminais de integração (sendo essa uma integração física). Nesse período as canaletas para os ônibus correspondiam a apenas $19 \mathrm{~km}$ de extensão, mas já se criou o importante sistema de definição hierárquica das linhas pelas cores, sendo o vermelho para as linhas expressas e o laranja para as linhas alimentadoras. Apenas $9 \%$ do sistema era integrado. 


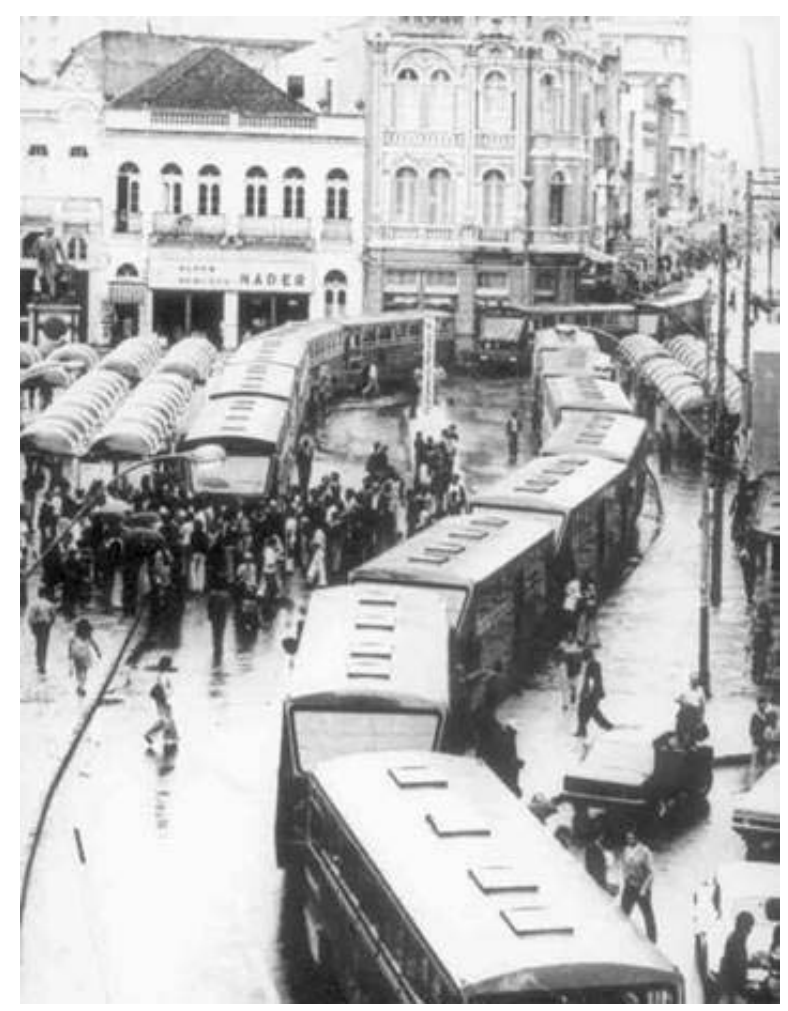

Figura 6: Sistema de transporte público de Curitiba em sua inauguração, no ano de 1974 Fonte: www.onibusdecuritiba.com.br, 2010.

Ao longo dos anos o sistema evoluiu de forma contínua, sendo que atualmente a cidade conta com seis corredores em funcionamento, 21 terminais de integração, sistema de bilhetagem eletrônica, 12 hierarquias de linha, abrangência metropolitana, além das conhecidas estações tubo (paradas de ônibus que permitem bilhetagem prévia e embarque em nível).

\subsubsection{Eixos Estruturais}

Também chamados de corredores, eles formam braços de desenvolvimento e atualmente abrangem quase todas as áreas da cidade. Segundo o IPPUC (2008), dividem-se em tipos distintos:

- Via exclusiva: presente no centro da cidade em uma única rua (Travessa da Lapa) onde excepcionalmente é permitida a circulação de outros veículos, para acesso às garagens particulares;

- Canaleta exclusiva: segmento da via central do sistema trinário destinado à circulação das linhas expressas; 
- Faixa exclusiva: segmento da faixa carroçável de determinadas vias, destinada à circulação dos ônibus de uma linha expressa específica, definida por tachões;

- Via compartilhada: presentes em alguns segmentos dos eixos, especialmente na área central e em trechos do eixo oeste, nos quais a circulação das linhas expressas é compartilhada com os demais veículos;

A distribuição espacial dos Eixos Estruturais na cidade é apresentada na Figura 7 e a Figura 8 mostra uma vista atual do eixo Norte-Sul.

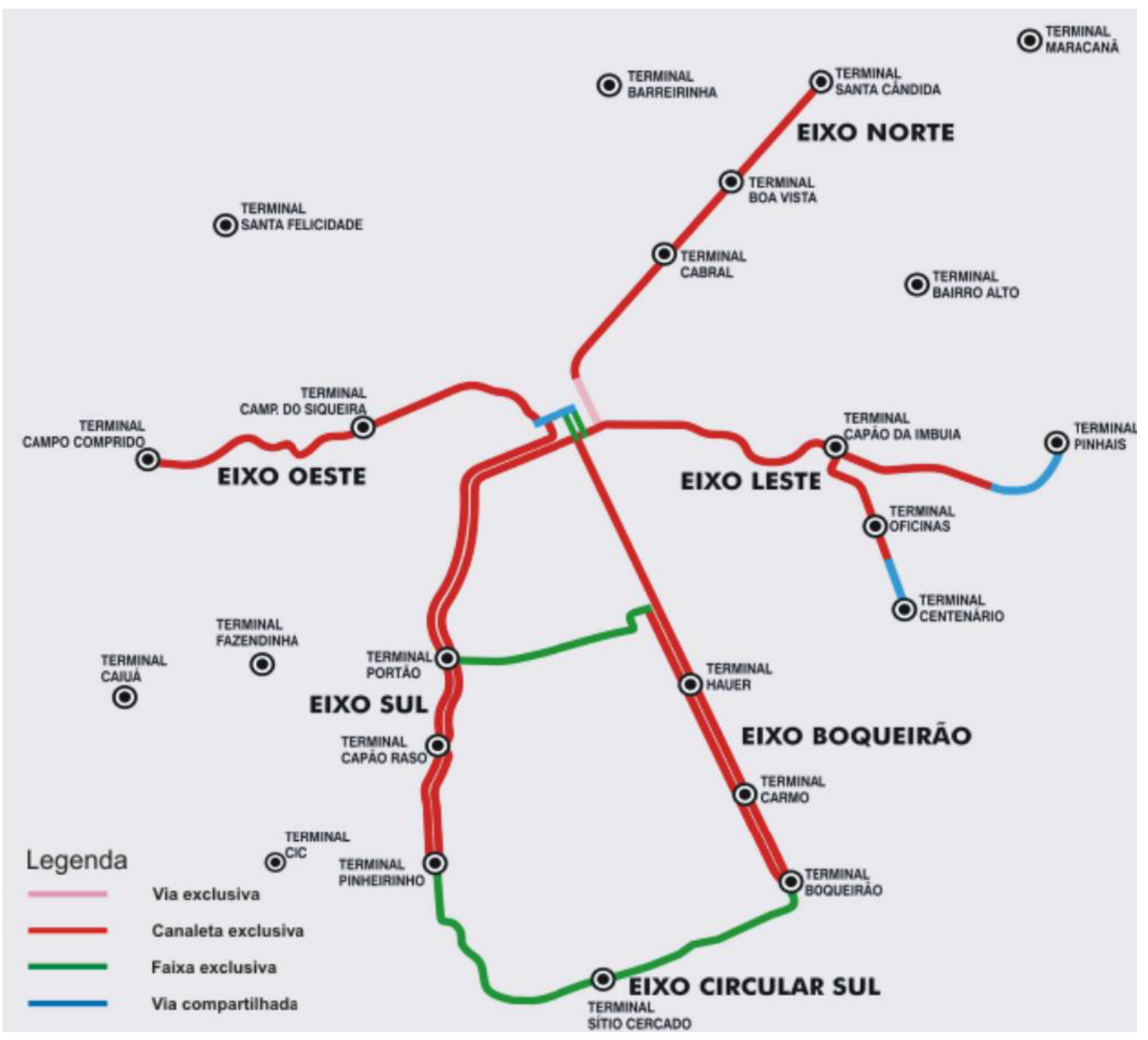

Figura 7: Distribuição dos Eixos Estruturais em Curitiba

Fonte: PlanMob Curitiba, IPPUC, 2008 


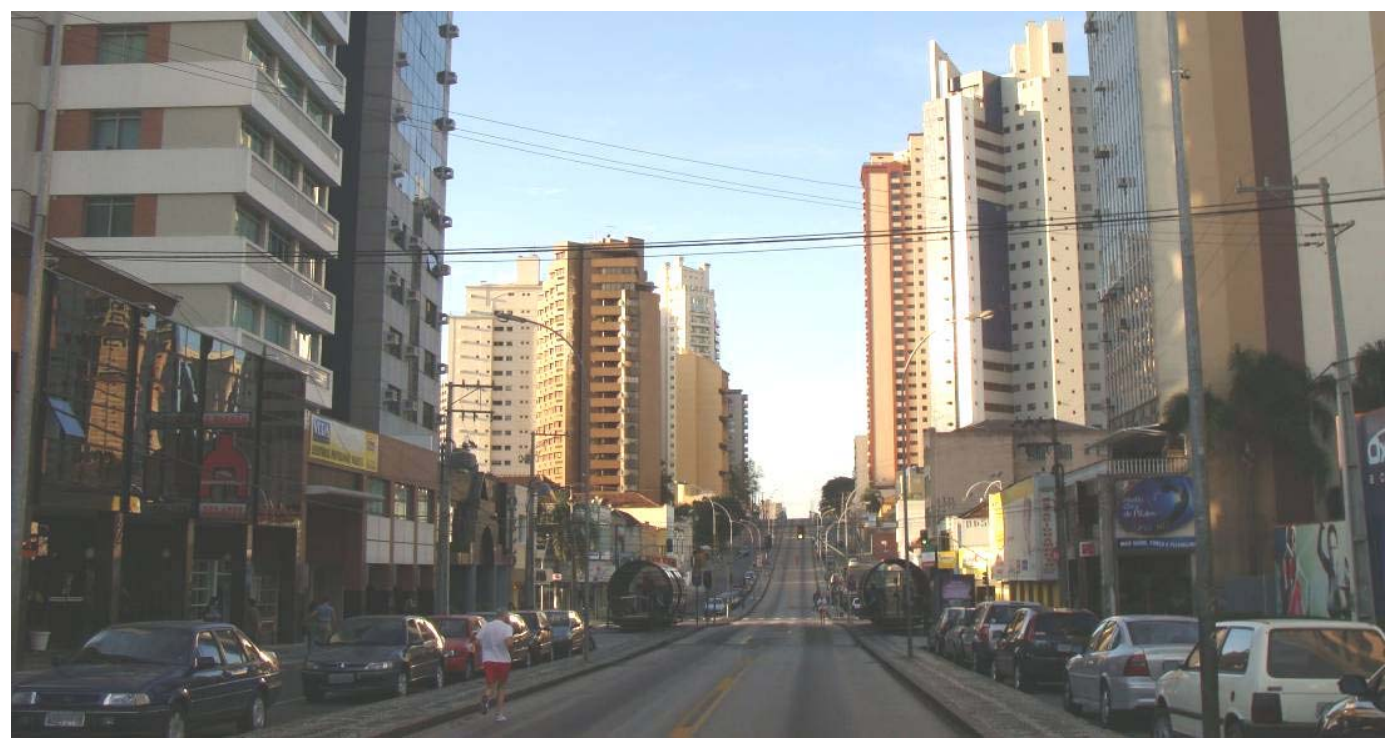

Figura 8: Eixo Norte-Sul, com canaleta exclusiva

Fonte: www.panoramio.com, 2010.

\subsubsection{Linha Verde}

A Linha Verde é o sexto corredor de transporte público, que ainda encontra-se em processo de implantação. O projeto trata da requalificação urbana da antiga BR-116, que atravessa toda a cidade, modificando suas características para receber um novo corredor de ônibus, de forma a ampliar a capacidade do sistema de transporte público.

A nova avenida irá promover a ligação das regiões Nordeste e Sudoeste da cidade, estendendo-se por $18 \mathrm{~km}$ e 23 bairros. Sua concepção é basicamente a mesma dos Eixos Estruturais anteriores, com um sistema trinário, composto por via central que recebe o transporte de massa e duas vias externas funcionando como binários. $\mathrm{A}$ diferença clara na nova proposta é a largura das vias internas, que abriga mais faixas de rolamento e as vias de trânsito lento. Tal condição deve-se ao fato de que a área que abriga a Linha Verde correspondia a uma rodovia federal com suas faixas de domínio, assim, a largura da nova avenida pode variar de 60 a 80 metros.

Os padrões de uso do solo na Linha Verde também diferem daqueles existentes nos corredores tradicionais. A verticalização mais intensa restringe-se às áreas próximas às estações de embarque e desembarque, chamados de Polos. O IPPUC (2008) define os Polos como áreas de ocupação e paisagem diferenciados de média e alta densidades, onde se pretende adensamento, verticalização e ocupação de usos 
mistos, identificados por edifícios de altura livre, com funções de habitação, trabalho e recreação. Para incentivar esse adensamento pretendido, a verticalização, renovação dos usos existentes e otimização da infraestrutura instalada, os terrenos situados nos Polos da Linha Verde podem obter acréscimo de potencial construtivo oriundo de outorga onerosa ou transferência do direito de construir.

A Figura 9 mostra as obras de implantação da Linha Verde, com tubos de grandes dimensões e ciclovias em toda sua extensão.

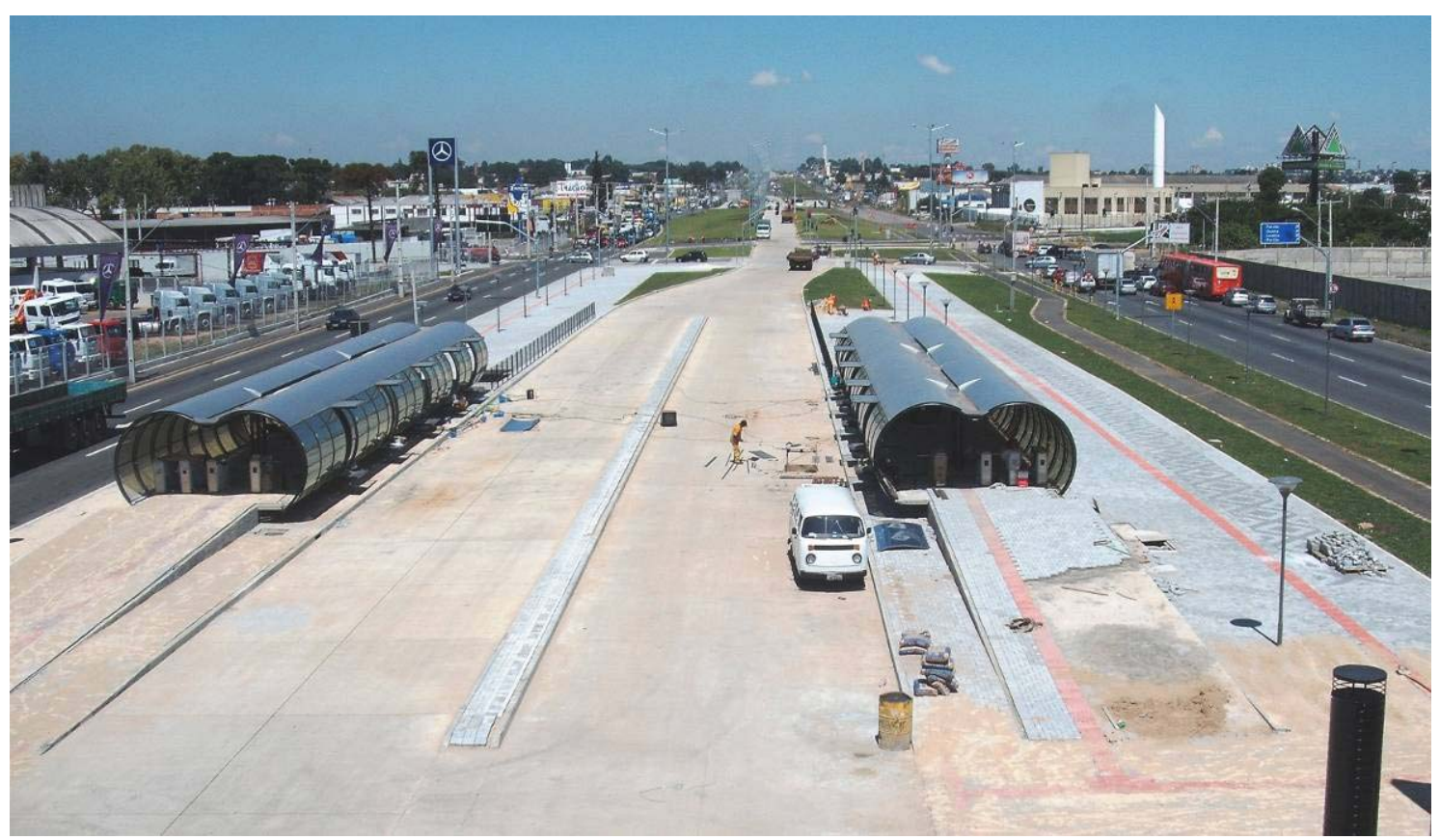

Figura 9: Obras de implantação da Linha Verde Fonte: www.panoramio.com, 2010.

\subsubsection{Linhas do Transporte Coletivo}

O IPPUC (2208) define que o sistema de transporte coletivo da cidade de Curitiba é composto por linhas urbanas e metropolitanas. Caracterizadas de acordo com sua função e categoria, dessa forma elas distinguem-se por cores, conforme descrição a seguir.

- Expressas: constituem o sistema do transporte de massa na cidade, transitam em vias próprias segregadas (os Eixos Estruturantes), possuem a cor vermelha e promovem a ligação dos terminais de integração à área central. Seus 
veículos são biarticulados (270 passageiros) ou articulados (180 passageiros) e suas paradas são constituídas por estações tubo;

- Alimentadoras: promovem a ligação dos terminais de integração aos bairros locais. Possuem a cor laranja e utilizam veículos com capacidades variadas, dependendo de sua demanda;

- Interbairros: interligam terminais e bairros de regiões diversas da cidade sem passar pela região central. De cor verde, utilizam veículos de capacidades variadas (110 a 160 passageiros);

- Diretas: constituem linhas auxiliares às expressas e interbairros e promovem ligações pontuais mais distantes, com paradas médias a cada $3 \mathrm{~km}$. Sua cor é prata e receberam o apelido de "ligeirinho";

- Troncais: promovem a ligação dos terminais de bairro ao centro. De cor amarela, seus veículos possuem capacidade de 96 a 160 passageiros;

- Intercidades: correspondem à ligação de municípios metropolitanos aos terminais urbanos. De cor laranja, seus veículos comportam 94 passageiros;

- Convencionais: compreendem a ligação das áreas da cidade não atendidas pelos terminais de integração. Seus veículos são de cor amarela e possuem capacidade variável de 40 a 160 passageiros;

- Circular Centro: promove a ligação de pontos do centro expandido da cidade. Utiliza-se de micro-ônibus na cor branca;

- Inter-hospitais: atendem um público que necessita deslocar-se entre hospitais, clínicas e laboratórios próximos à área central da cidade. Com veículos na cor branca, seu leiaute é específico, com capacidade para 22 passageiros;

- Madrugueiros: atendem um público que desenvolve suas atividades noturnas, em períodos fora dos horários de operação do sistema;

- Sites: correspondem às linhas do Sistema Integrado de Ensino Especial, e atendem às escolas destinadas a portadores de deficiência (física ou mental). Seus veículos promovem o transporte porta à porta, ou seja, buscam seus usuários em suas casas e os levam às instituições de ensino a que se destinam, passando por um terminal de integração. Todos os veículos são adaptados às condições de seus usuários;

- Aeroporto (executivo): promove a ligação do Aeroporto Internacional Afonso Pena à área central da capital. Seu veículo corresponde a um micro-ônibus na cor prata. 


\subsubsection{Terminais de integração}

Os terminais de integração correspondem à ligação das linhas que compõem a chamada RIT (Rede Integrada de Transporte), no município de Curitiba e também na região metropolitana. Assim como as linhas do transporte público são divididas em categorias, eles também recebem classificação, sendo divididos em: terminais de ponta, terminais intermediários, terminais de bairros, terminais na área central e terminais metropolitanos. Tal divisão, como o próprio nome sugere, indica a posição dos mesmos no sistema de transporte, conforme indica a Figura 10. 


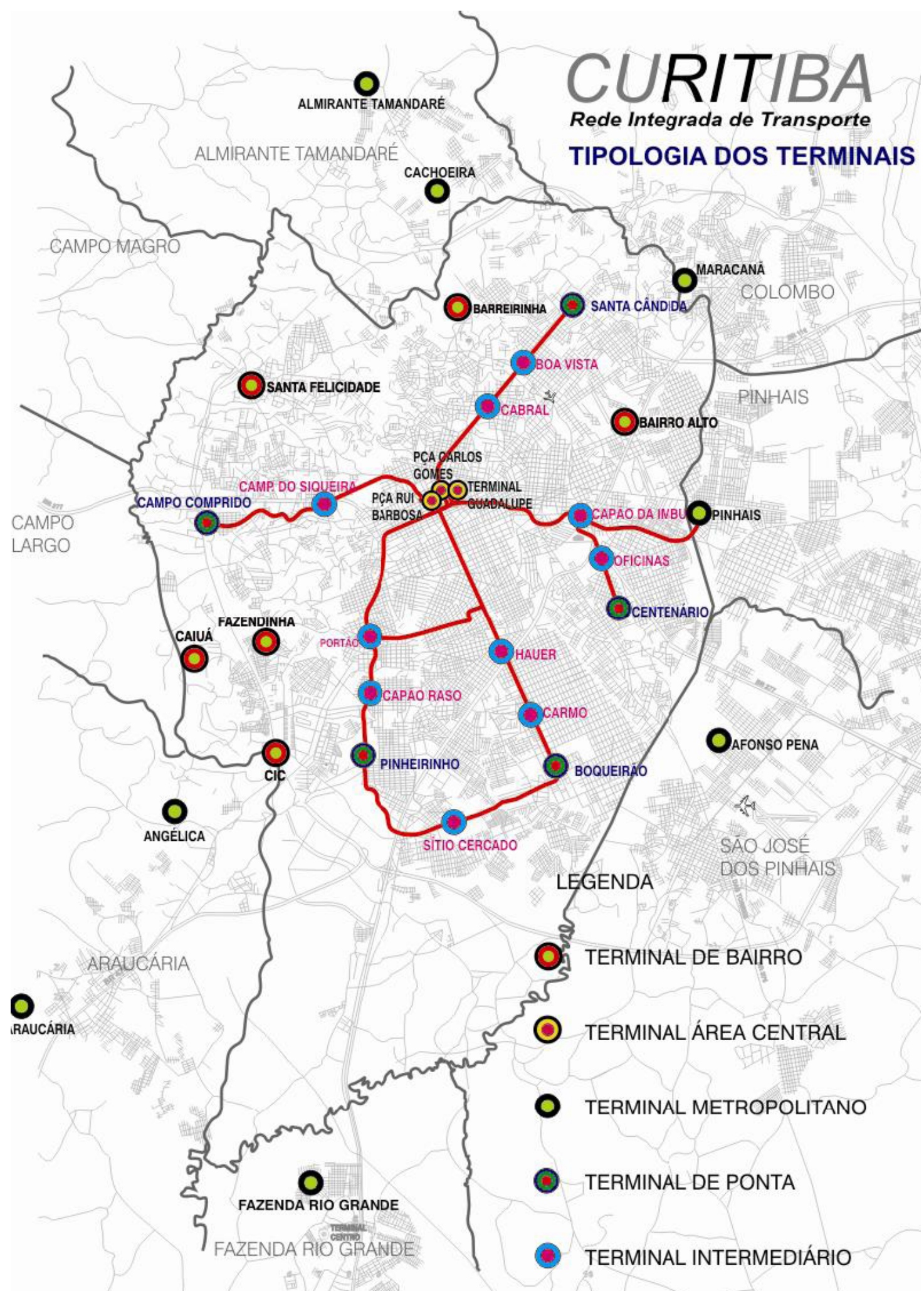

Figura 10: Localização de integração do transporte público com definição de sua classificação Fonte: PlanMob Curitiba, IPPUC, 2008.

Os terminais de ponta encontram-se nas extremidades dos Eixos Estruturais e abrigam um número maior de linhas alimentadoras (Figura 11). Terminais 
intermediários são encontrados em todos os eixos do sistema de transporte e, apesar do menor porte, também promovem a integração de diversas linhas alimentadoras e metropolitanas (Figura 12). Os terminais de bairro encontram-se fora dos Eixos Estruturais, mas assim como os anteriores, também promovem a integração do transporte metropolitano ao municipal.
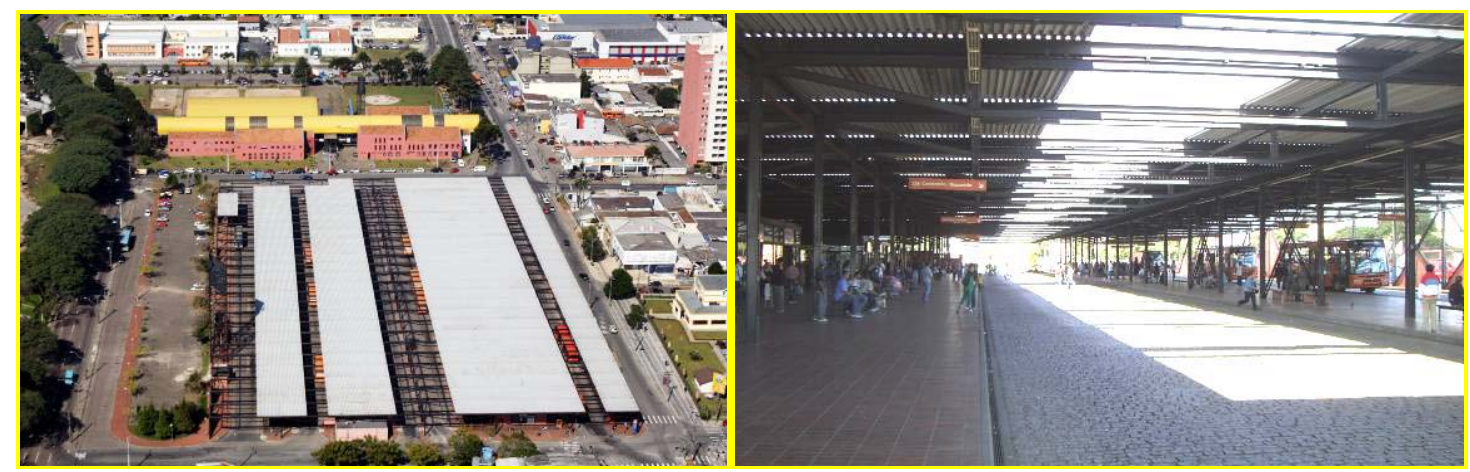

Figura 11: Terminais de ponta (Terminal Pinheirinho e Terminal Boqueirão) Fonte: www.panoramio.com, 2010.
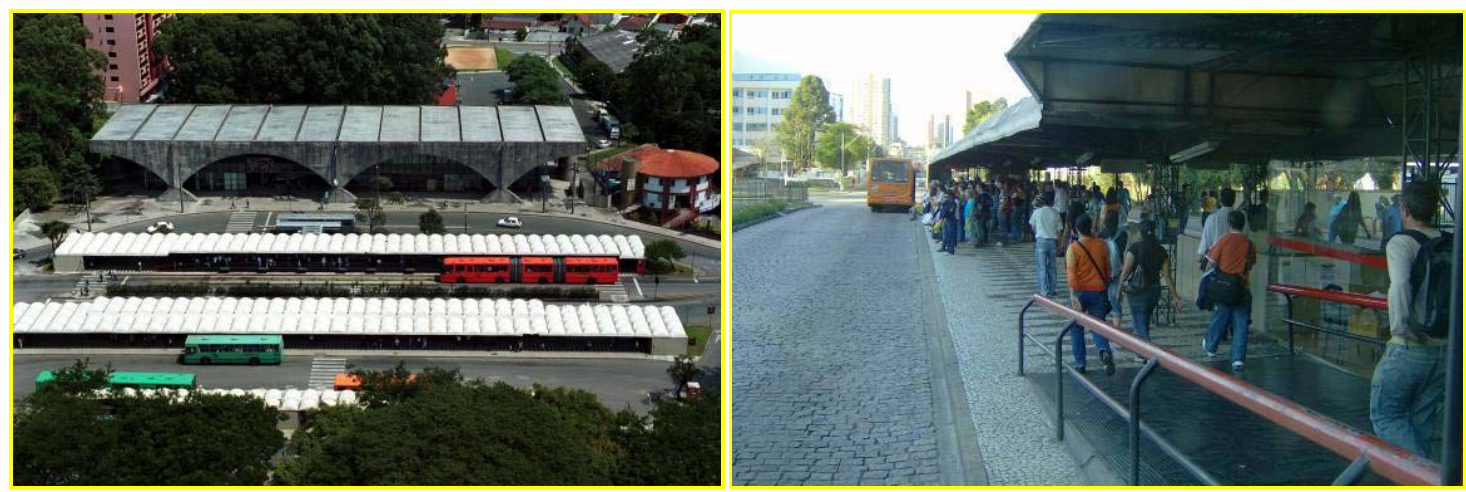

Figura 12: Terminais intermediários (Terminal Portão e Terminal Cabral)

Fonte: www.panoramio.com, 2010.

Os terminais nas áreas centrais recebem esse nome apenas por concentrarem certa quantidade de linhas do transporte público no mesmo espaço, geralmente uma praça pública, como é o caso da Praça Rui Barbosa (ver Figura 13), o maior de todos esses terminais. Os terminais metropolitanos são responsáveis por atender às demandas de transporte de passageiros dos municípios vizinhos à Curitiba através da RIT. 


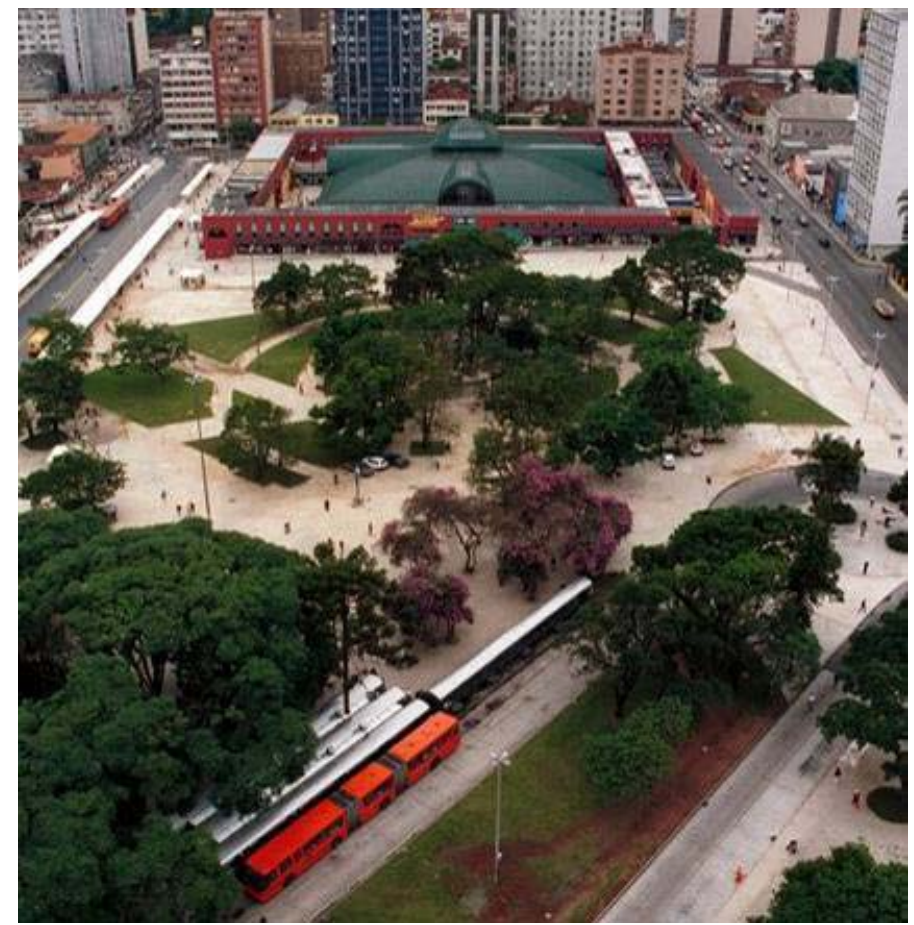

Figura 13: Terminal central (Praça Rui Barbosa)

Fonte: www.panoramio.com, 2010.

Além da diversidade de terminais, os pontos de parada também apresentam padrões definidos por sua hierarquia. As estações tubo são bastante conhecidas como um modelo do transporte público diferenciado da cidade de Curitiba. Suas principais qualidades são proporcionar embarque e desembarque de passageiros em nível, com o pagamento da tarifa antecipadamente e atender às linhas das categorias expressas e diretas. O destaque das estações tubo encontra-se na acessibilidade, pois seu embarque ocorre em plataforma elevada. Oferece elevador ou rampa de acesso a usuários com restrições de mobilidade, conforme Figura 14.

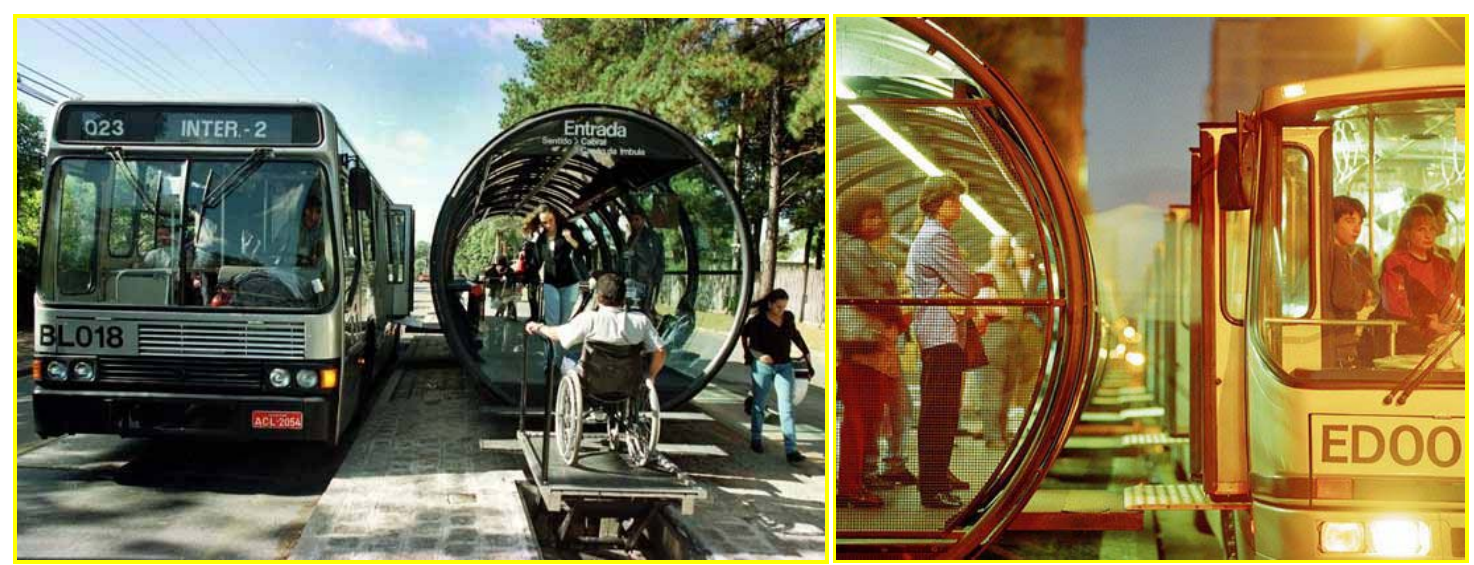

Figura 14: Estações tubo, elevador e embarque em nível Fonte: www.panoramio.com, 2010. 


\section{METODOLOGIA}

A presente seção corresponde à descrição do método proposto para a realização do estudo, contrapondo a estrutura do índice com a disponibilidade dos dados necessários para sua aplicação. Ainda foram consideradas duas propostas diversas de comparação de resultados: a primeira considerando uma análise intraurbana e a segunda considerando uma comparação de desempenho entre cidades distintas.

\subsection{Abordagem Adotada}

Costa (2008) define o IMUS como uma ferramenta para avaliação da mobilidade urbana, capaz de revelar as condições atuais e medir os impactos de medidas e estratégias visando à mobilidade sustentável. Sua composição é dada por nove domínios, distribuídos em 37 temas e 87 indicadores (ver Tabela 1). O índice foi formulado para incluir tanto questões tradicionais quanto as relacionadas ao novo paradigma da mobilidade sustentável, possuindo a essencial qualidade de se adaptar a diversas realidades urbanas, graças a sua composição diversificada.

Seus indicadores são avaliados por um sistema de pesos que os qualifica de forma individual e também em grupo, possibilitando reconhecer a contribuição relativa de cada elemento para todo o conjunto. Essa qualidade permite que o índice seja utilizado para a formulação de políticas integradas ou direcionadas da mobilidade, favorecendo uma aplicação mais racional e eficiente de recursos (MIRANDA et al., 2009). A aplicação destas avaliações nas cidades permite a identificação de fatores críticos e de maior impacto para a melhoria de aspectos globais e setoriais da mobilidade urbana, fornecendo subsídios para a proposição de políticas e estratégias visando à mobilidade sustentável (COSTA, 2008). 
Tabela 1: Estrutura do IMUS

\begin{tabular}{|c|c|c|c|c|c|c|}
\hline \multirow{2}{*}{$\begin{array}{l}\text { DOM ÍNIO } \\
\text { (peso) }\end{array}$} & \multicolumn{3}{|c|}{ DIMENSÕES } & \multirow{2}{*}{ TEMAS (peso) } & \multirow{2}{*}{ INDICADORES } & \multirow{2}{*}{ PESO } \\
\hline & $\mathbf{s}$ & $\mathrm{E}$ & $\mathbf{A}$ & & & \\
\hline \multirow{11}{*}{ 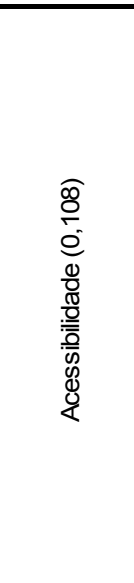 } & & 0,36 & $\overline{0,26}$ & Acessibilidade aos sistemas & 1.1.1 Acessibilidade ao transporte público & 0,33 \\
\hline & & & & & $\begin{array}{l}\text { Transporte público para pessoas com } \\
\text { necessidades especiais }\end{array}$ & 0,33 \\
\hline & & & & & 1.1.3 Despesas com transportes & 0,33 \\
\hline & & 0,32 & 0,27 & $\begin{array}{l}\text { Acessibilidade universal } \\
(0,28)\end{array}$ & $\begin{array}{l}\text { 1.2.1 Travessias adaptadas para pessoas com } \\
\text { necessidades especiais }\end{array}$ & 0,2 \\
\hline & & & & & 1.2.2 Acessibilidade aos espaços abertos & 0,2 \\
\hline & & & & & $\begin{array}{l}\text { 1.2.3 Vagas de estacionamento para pessoas com } \\
\text { necessidades especiais }\end{array}$ & 0,2 \\
\hline & & & & & 1.2.4 Acessibilidade a edifícios públicos & 0,2 \\
\hline & & & & & 1.2.5 Acessibilidade aos serviços essenciais & 0,2 \\
\hline & & 0,30 & 0,32 & Barreiras físicas $(0,22)$ & 1.3.1 Fragmentação urbana & 1 \\
\hline & & & & Legislação para pessoas com & & \\
\hline & & 0,28 & 0,27 & $\frac{\text { necessidades especiais }}{(0,21)}$ & 1.4.1 Ações para acessibilidade universal & 1 \\
\hline \multirow{6}{*}{ 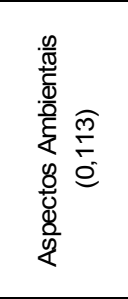 } & & 0,28 & 0,43 & Controle dos impactos no meio & 2.1.1 Emissões de CO & 0,25 \\
\hline & & & & ambiente $(0,52)$ & 2.1.2 Emissões de $\mathrm{CO}_{2}$ & 0,25 \\
\hline & & & & & 2.1.3 População exposta ao ruído de tráfego & 0,25 \\
\hline & & & & & 2.1.4 Estudos de impacto ambiental & 0,25 \\
\hline & & 0,32 & 0,42 & Recursos naturais $(0,48)$ & 2.2.1 Consumo de combustível & 0,5 \\
\hline & & & & & $\begin{array}{l}\text { Uso de energia limpa e combustíveis } \\
\text { alternativos }\end{array}$ & 0,5 \\
\hline \multirow{5}{*}{ 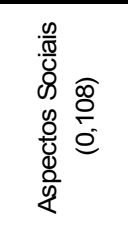 } & 0,40 & 0,31 & 0,29 & Apoio ao cidadão $(0,21)$ & 3.1.1 Informação disponível ao cidadão & 1 \\
\hline & 0,45 & 0,30 & 0,25 & Inclusão social $(0,20)$ & 3.2.1 Equidade vertical (renda) & 1 \\
\hline & 0,39 & 0,30 & 0,31 & Educação e cidadania $(0,19)$ & 3.3.1 Educação para o desenvolvimento sustentável & 1 \\
\hline & & 0,27 & 0,32 & Participação popular $(0,19)$ & 3.4.1 Participação na tomada de decisão & 1 \\
\hline & & 0,30 & 0,35 & Qualidade de vida $(0,21)$ & 3.5.1 Qualidade de vida & 1 \\
\hline \multirow{7}{*}{$\begin{array}{l}\widehat{m} \\
\frac{0}{E} \\
0 \\
0 \\
0 \\
00 \\
\frac{0}{0} \\
0 \\
0 \\
\frac{8}{0} \\
\frac{8}{0} \\
\frac{8}{4}\end{array}$} & & 0,34 & 0,32 & Integração de ações políticas & 4.1.1 Integração entre níveis de governo & 0,5 \\
\hline & & & & $(0,34)$ & 4.1.2 Parcerias público-privadas & 0,5 \\
\hline & & 0,40 & 0,27 & Captação e gerenciamento de & 4.2.1 Captação de recursos & 0,25 \\
\hline & & & & recursos $(0,33)$ & 4.2.2 Investimentos em sistemas de transporte & 0,25 \\
\hline & & & & & 4.2.3 Distribuição dos recursos (coletivo $x$ privado) & 0,25 \\
\hline & & & & & $\begin{array}{l}\text { 4.2.4 Distribuição dos recursos (motorizados } x \text { não } \\
\text { motorizados) }\end{array}$ & 0,25 \\
\hline & & 0,33 & 0,32 & $\begin{array}{l}\text { Politica de mobilidade urbana } \\
(0,33)\end{array}$ & 4.3.1 Política de mobilidade urbana & 1 \\
\hline \multirow{5}{*}{ 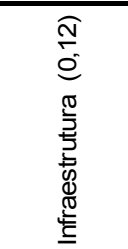 } & 0,28 & 0,41 & 0,31 & Provisão e manutenção da & 5.1.1 Densidade e conectividade da rede viária & 0,25 \\
\hline & & & & - infraestrutura de transportes & 5.1.2 Vias pavimentadas & 0,25 \\
\hline & & & & & 5.1.3 Despesas com manutenção da infraestrutura & 0,25 \\
\hline & & & & & 5.1.4 Sinalização viária & 0,25 \\
\hline & 33 & 0,35 & 0,33 & $\begin{array}{l}\text { Distribuição da infraestrutura } \\
\text { de transporte }(0,54)\end{array}$ & 5.2.1 Vias para transporte coletivo & 1 \\
\hline \multirow{9}{*}{ 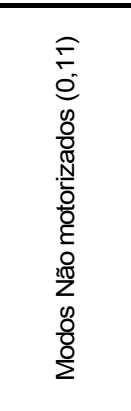 } & 32 & 0,29 & 0,39 & Transporte cicloviário $(0,31)$ & 6.1.1 Extensão e conectividade de ciclovias & 0,33 \\
\hline & & & & & 6.1.2 Frotas de bicicletas & 0,33 \\
\hline & & & & & 6.1.3 Estacionamento de bicicletas & 0,33 \\
\hline & 0,33 & 0,28 & 0,39 & Deslocamentos a pé $(0,34)$ & 6.2.1 Vias para pedestres & 0,5 \\
\hline & & & & & 6.2.2 Vias com calçadas & 0,5 \\
\hline & & 0,32 & 0,40 & Redução de viagens $(0,35)$ & 6.3.1 Distância de viagem & 0,25 \\
\hline & & & & & 6.3.2 Tempo de viagem & 0,25 \\
\hline & & & & & 6.3.3 Número de viagens & 0,25 \\
\hline & & & & & 6.3.4 Ações para redução do tráfego motorizado & 0,25 \\
\hline
\end{tabular}

Fonte: Costa (2008) 
Tabela 1: (continuação) Estrutura do IMUS

\begin{tabular}{|c|c|c|c|c|c|c|}
\hline \multirow{2}{*}{$\begin{array}{l}\text { DOMíNIO } \\
\text { (peso) }\end{array}$} & \multicolumn{3}{|c|}{ DIMENSÕES } & \multirow{2}{*}{ TEMAS (peso) } & \multirow{2}{*}{ INDICADORES } & \multirow{2}{*}{ PESO } \\
\hline & $\mathbf{s}$ & $\mathrm{E}$ & $\mathbf{A}$ & & & \\
\hline \multirow{18}{*}{ 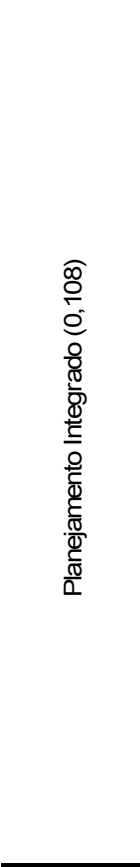 } & & 0,37 & 0,32 & \multirow{2}{*}{$\frac{\text { Capacitação de gestores }}{(0,12)}$} & 7.1.1 Nível de formação de técnicos e gestores & 0,5 \\
\hline & & & & & 7.1.2 Capacitação de técnicos e gestores & 0,5 \\
\hline & & 0,30 & 0,35 & $\begin{array}{l}\text { Áreas centrais e de interesse } \\
\text { histórico }(0,11)\end{array}$ & 7.2.1 Vitalidade do centro & 1 \\
\hline & & 0,34 & 0,35 & Integração regional $(0,12)$ & 7.3.1 Consórcios intermunicipais & 1 \\
\hline & & 0,32 & 0,31 & $\frac{\text { Transparência do processo }}{\text { de planejamento }(0,12)}$ & 7.4.1 Transparência e responsabilidade & 1 \\
\hline & 0,3 & 0,32 & 0,36 & \multirow{5}{*}{$\begin{array}{l}\text { Planejamento e controle do } \\
\text { uso e ocupação do solo }(0,14)\end{array}$} & 7.5.1 Vazios urbanos & 0,2 \\
\hline & & & & & 7.5.2 Crescimento urbano & 0,2 \\
\hline & & & & & 7.5.3 Densidade populacional urbana & 0,2 \\
\hline & & & & & 7.5.4 Índice de uso misto & 0,2 \\
\hline & & & & & 7.5.5 Ocupações irregulares & 0,2 \\
\hline & & 0,35 & 0,33 & $\begin{array}{l}\text { Planejamento estratégico e } \\
\text { integrado }(0,14)\end{array}$ & $\begin{array}{l}\text { 7.6.1 Planejamento urbano, ambiental e de } \\
\text { transporte integrado }\end{array}$ & 0,5 \\
\hline & & & & & 7.6.2 Efetivação e continuidade das ações & 0,5 \\
\hline & & 0,39 & 0,30 & \multirow{3}{*}{$\begin{array}{l}\text { Planejamento da infraestrutura } \\
\text { urbana e equipamentos } \\
\text { urbanos }(0,13)\end{array}$} & 7.7.1 Parques e áreas verdes & 0,33 \\
\hline & & & & & 7.7.2 Equipamentos urbanos (escolas) & 0,33 \\
\hline & & & & & 7.7.3 Equipamentos urbanos (postos de saúde) & 0,33 \\
\hline & & 0,35 & 0,35 & \multirow{3}{*}{$\begin{array}{l}\text { Plano diretor e legislação } \\
\text { urbanística }(0,12)\end{array}$} & 7.8.1 Plano diretor & 0,33 \\
\hline & & & & & 7.8.2 Legislação urbanística & 0,33 \\
\hline & & & & & 7.8.3 Cumprimento da legislação urbanística & 0,33 \\
\hline \multirow{9}{*}{ 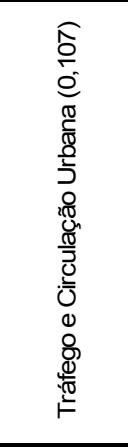 } & & 0,38 & 0,26 & \multirow[t]{3}{*}{ Acidentes de trânsito $(0,21)$} & 8.1.1 Acidentes de trânsito & 0,33 \\
\hline & & & & & 8.1.2 Acidentes com pedestres e ciclistas & 0,33 \\
\hline & & & & & 8.1.3 Prevenção de acidentes & 0,33 \\
\hline & & 0,31 & 0,30 & $\begin{array}{l}\text { Educação para o trânsito } \\
(0,19)\end{array}$ & 8.2.1 Educação para o trânsito & 1 \\
\hline & 1,29 & 0,35 & 0,36 & Fluidez e circulação $(0,19)$ & 8.3.1 Congestionamento & 0,5 \\
\hline & & & & & 8.3.2 Velocidade média do tráfego & 0,5 \\
\hline & & 0,33 & 0,33 & $\begin{array}{l}\text { Operação e fiscalização de } \\
\text { trânsito }(0,20)\end{array}$ & 8.4.1 Violação das leis de trânsito & 1 \\
\hline & , 32 & 0,31 & 0,36 & Transporte individual $(0,21)$ & 8.5.1 Índice de motorização & 0,5 \\
\hline & & & & & 8.5.2 Taxa de ocupação de veículos & 0,5 \\
\hline \multirow{18}{*}{ 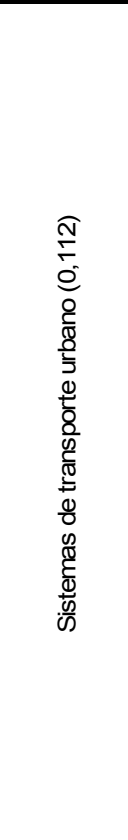 } & & 0,33 & 0,32 & \multirow{8}{*}{ Disponibilidade e qualidade do } & 9.1.1 Extensão da rede transporte público & 0,12 \\
\hline & & & & & $\begin{array}{l}\text { 9.1.2 Frequência de atendimento do transporte } \\
\text { público }\end{array}$ & 0,12 \\
\hline & & & & & 9.1.3 Pontualidade & 0,12 \\
\hline & & & & & 9.1.4 Velocidade média do transporte público & 0,12 \\
\hline & & & & & 9.1.5 Idade média da frota de transporte público & 0,12 \\
\hline & & & & & 9.1.6 Índice de passageiros por quilômetro & 0,12 \\
\hline & & & & & 9.1.7 Passageiros transportados anualmente & 0,12 \\
\hline & & & & & $\begin{array}{l}\text { 9.1.8 Satisfação do usuário com o serviço de } \\
\text { transporte público }\end{array}$ & 0,12 \\
\hline & 0,3 & 0,34 & 0,34 & \multirow[t]{3}{*}{ Diversificação modal $(0,18)$} & 9.2.1 Diversidade de modos de transporte & 0,33 \\
\hline & & & & & 9.2.2 Transporte coletivo $x$ transporte individual & 0,33 \\
\hline & & & & & 9.2.3 Modos não motorizados $x$ modos motorizados & 0,33 \\
\hline & & 0,35 & 0,31 & \multirow{2}{*}{$\begin{array}{l}\text { Regulação e fiscalização do } \\
\text { transporte público }(0,18)\end{array}$} & 9.3.1 Contratos e licitações & 0,5 \\
\hline & & & & & 9.3.2 Transporte clandestino & 0,5 \\
\hline & 37 & 0,33 & 0,30 & \multirow{2}{*}{$\begin{array}{l}\text { Integração do transporte } \\
\text { público }(0,22)\end{array}$} & 9.4.1 Terminais intermodais & 0,5 \\
\hline & & & & & 9.4.2 Integração do transporte público & 0,5 \\
\hline & & 0,37 & 0,35 & \multirow[t]{3}{*}{ Política tarifária $(0,19)$} & 9.5.1 Descontos e gratuidades & 0,33 \\
\hline & & & & & 9.5.2 Tarifas de transporte & 0,33 \\
\hline & & & & & 9.5.3 Subsídios públicos & 0,33 \\
\hline
\end{tabular}

Fonte: Costa (2008) 


\subsection{Identificação da Estrutura do IMUS}

A aplicação do IMUS numa cidade tem início com a avaliação da disponibilidade e qualidade das informações necessárias. O índice necessita de um grande conjunto de dados e muitas vezes tais informações não são propriamente confiáveis, oriundas de fontes seguras, ou não se encontram disponíveis para uso imediato. Nesses casos tais indicadores podem não ser avaliados, ou por não representarem a realidade ou por impossibilidade de cálculo. Assim, é necessária uma avaliação prévia de quais dados estão efetivamente disponíveis, de forma a detectar previamente se o cálculo do índice pode ser inviabilizado por falta de informações.

Dessa forma, foram listados todos os dados necessários para o cálculo dos 87 indicadores, bem como suas possíveis fontes. Com o auxílio de um profissional da prefeitura, as informações obtidas passaram por uma análise que considerou sua disponibilidade e também sua qualidade.

A disponibilidade dos dados foi dividida em prazos que indicam a demora na obtenção das informações: curto prazo (CP), médio prazo (MP) e longo prazo (LP). Curto prazo corresponde ao caso de dados que já existem ou que podem ser obtidos em até um ano, médio prazo equivale ao caso que os dados podem ser obtidos em até uma gestão administrativa e longo prazo corresponde ao caso de dados que necessitam de tempo superior a uma gestão administrativa para serem obtidos.

A qualidade dos dados é dada conforme a confiabilidade da fonte de informação e é dividida da seguinte forma: alta (A), média (M) e baixa (B). Muitas vezes as informações necessárias à aplicação do índice são produzidas pela prefeitura do município, como bancos de dados ou mapeamentos. Essas informações podem em geral ser consideradas de boa procedência, uma vez que a administração municipal é uma das fontes mais indicadas para fornecer dados confiáveis, pois ela mesma faz uso desses para desenvolver suas políticas públicas. Outras vezes algumas dessas informações são encontradas em fontes não oficiais, como reportagens de jornais e revistas. Sem dúvida, tais referências podem ser responsáveis por informações valiosas, mas nem sempre são confiáveis, uma vez que não demonstram preocupação científica ou muitas vezes preocupam-se mais em produzir jornalismo sensacionalista. De qualquer maneira, é essencial que as fontes responsáveis pelas informações 
necessárias ao cálculo dos indicadores sejam idôneas e que as mesmas estejam também atualizadas no momento do cálculo do IMUS.

\subsubsection{Avaliação da disponibilidade e da qualidade}

A avaliação parte do julgamento de um profissional, de preferência funcionário da administração municipal, profundo conhecedor da organização interna da prefeitura e também dos bancos de dados municipais existentes. Tal pessoa estima, pelo seu próprio entendimento, a qualidade e disponibilidade das informações, conforme discriminação determinada. Dessa forma, são possíveis nove combinações dos dados, conforme Figura 15.

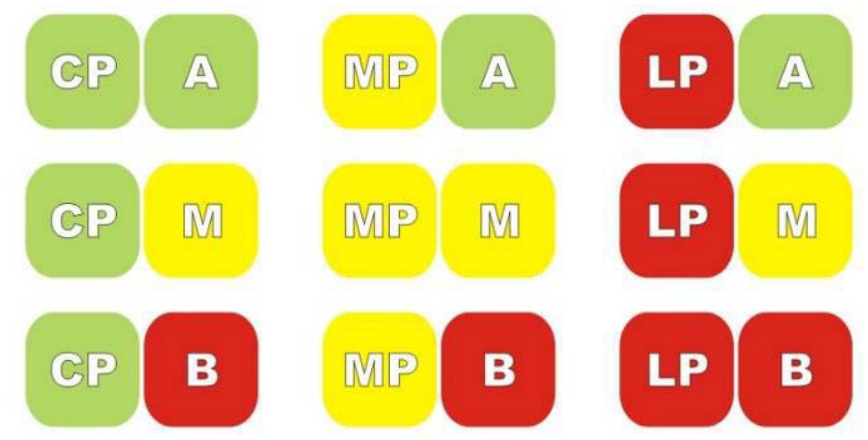

Figura 15: Combinações dos dados para disponibilidade (curto, médio e longo prazo) e qualidade (alta, média e baixa)

Dados obtidos em curto prazo correspondem ao uso imediato por parte do índice, sem necessidade de esperas que podem levar meses, ou até mesmo anos. Para aplicações imediatas do IMUS, informações obtidas a médio e longo prazo tornam-se um problema, obrigando a desconsiderar tal dado e seu respectivo indicador, o que pode resultar em prejuízos para o cálculo.

Considerando a necessidade de utilização da informação, dados com qualidade inferior podem vir a ser utilizados, desde que seu uso seja justificado. Afinal, quanto maior for o número de indicadores calculados, mais representativo será o resultado do índice para a cidade. É também importante considerar que poucos dados disponíveis para o cálculo do IMUS podem inviabilizar sua aplicação, pois mesmo em conjunto pouco serviriam para avaliar um município. 
De qualquer forma, a qualidade das informações não inviabiliza seu uso no índice, principalmente quando as mesmas forem escassas, pois em geral, a escolha dos dados utilizados deve-se a sua disponibilidade. Dessa forma, conclui-se que é essencialmente o tempo de obtenção da informação que define a sua utilização: dados disponíveis são, em geral, utilizados. Assim, pode-se considerar que das três colunas da Figura 15 que representam as possíveis combinações de avaliação dos dados, apenas a primeira coluna corresponde às informações efetivamente utilizadas para 0 índice.

\subsubsection{Dados não disponíveis}

Quando as informações necessárias não existem, ou não estão disponíveis, os indicadores correspondentes não podem ser calculados. Indicadores indisponíveis não inviabilizam o cálculo do indice, embora sua não avaliação deixe de registrar aspectos importantes da mobilidade urbana. Mas a estrutura do IMUS é adaptável à ausência de informações, de forma que os pesos dos indicadores indisponíveis são distribuídos aos demais, permitindo assim a manutenção das condições de obtenção do mesmo resultado para uma cidade com todos os indicadores calculados.

A distribuição dos pesos é dada de forma igualitária entre os indicadores que compõem o mesmo tema, assim como entre os temas que compõem o mesmo domínio (embora nesse caso seja mantida a proporção entre o número de indicadores por tema, para cada domínio), caso um dos temas não seja calculado por falta de seus indicadores.

A Tabela 2 apresenta um exemplo da distribuição dos pesos dos indicadores correspondentes ao domínio ACESSIBILIDADE e tema Acessibilidade aos sistemas de transporte. Sua análise permite perceber que, caso o primeiro indicador não fosse passível de cálculo, seu peso $(0,33)$ seria igualmente distribuído entre os demais indicadores, sendo que cada um acabaria com peso equivalente a 0,50. 
Tabela 2: Distribuição dos pesos

\begin{tabular}{|c|c|c|}
\hline INDICADORES & & PESO \\
\hline Acessibilidade ao transporte público & \multirow{3}{*}{$1,00 / 3$} & 0,33 \\
\hline Transporte público para pessoas com necessidades especiais & & 0,33 \\
\hline Despesas com transportes & & 0,33 \\
\hline INDICADORES & & PESO \\
\hline Acessibilidade ao transporte público & \multirow{3}{*}{$1,00 / 2$} & - \\
\hline Transporte público para pessoas com necessidades especiais & & 0,50 \\
\hline Despesas com transportes & & 0,50 \\
\hline \multicolumn{3}{|l|}{ Fonte: Adaptado de Costa (2008) } \\
\hline \multicolumn{3}{|c|}{$\begin{array}{l}\text { É importante considerar que indicadores não calculados podem encobrir pontos muito } \\
\text { fracos para a mobilidade, de forma até a provocar certo desequilíbrio no resultado final } \\
\text { do índice, caso esses sejam muitos. Isso se deve ao fato de que seus pesos são } \\
\text { divididos entre os demais indicadores, e caso o desempenho desses seja favorável, os }\end{array}$} \\
\hline
\end{tabular}

Assim, sempre se deve olhar com atenção os quesitos não contidos na avaliação e, acima de tudo, adotar uma visão crítica a respeito do resultado obtido para o índice global.

\subsection{Aplicação do Índice}

A aplicação do IMUS exige uma grande quantidade de informações, pois além do número elevado de indicadores, sua estrutura é bastante variada, agrupando assuntos das mais diversas áreas. Assim, várias instituições foram consultadas destacando-se as secretarias municipais, maiores fornecedoras de dados.

Os principais colaboradores foram sem dúvida o IPPUC (Instituto de Pesquisa e Planejamento Urbano de Curitiba) e a URBS (Urbanização de Curitiba). Essas duas instituições municipais representaram as maiores fontes de consulta, pois são as responsáveis pelo planejamento e efetivação das políticas e ações em prol da mobilidade em Curitiba. 
O IPPUC foi responsável por fornecer todas as informações espaciais, como mapas e bancos de dados da cidade, incluindo-se:

- Limite municipal;

- Distribuição da população na área urbana;

- Principais vias de circulação e corredores de transporte;

- Vias para o transporte coletivo;

- Terminais e pontos de parada do sistema de transporte;

- Áreas verdes e de lazer;

- Equipamentos de educação e saúde;

- Uso do solo municipal;

- Lotes e glebas vazias na área urbana;

- Ocupações irregulares na área urbana.

A Figura 16 e a Figura 17 apresentam os dados geográficos, fornecidos pelo IPPUC. 


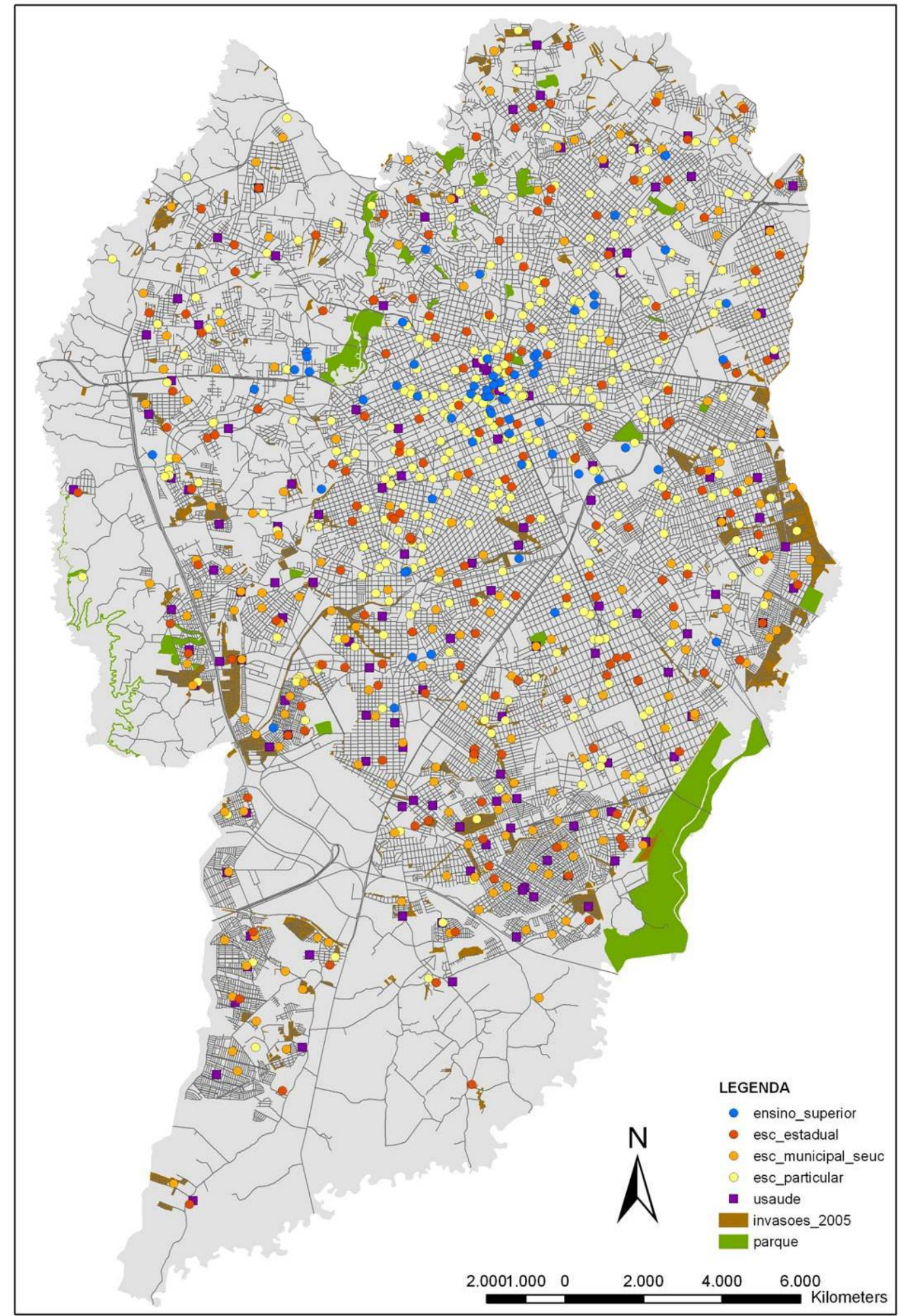

Figura 16: Dados geográficos: equipamentos de educação e lazer e áreas de invasão Fonte: Adaptado de IPPUC (2009) 


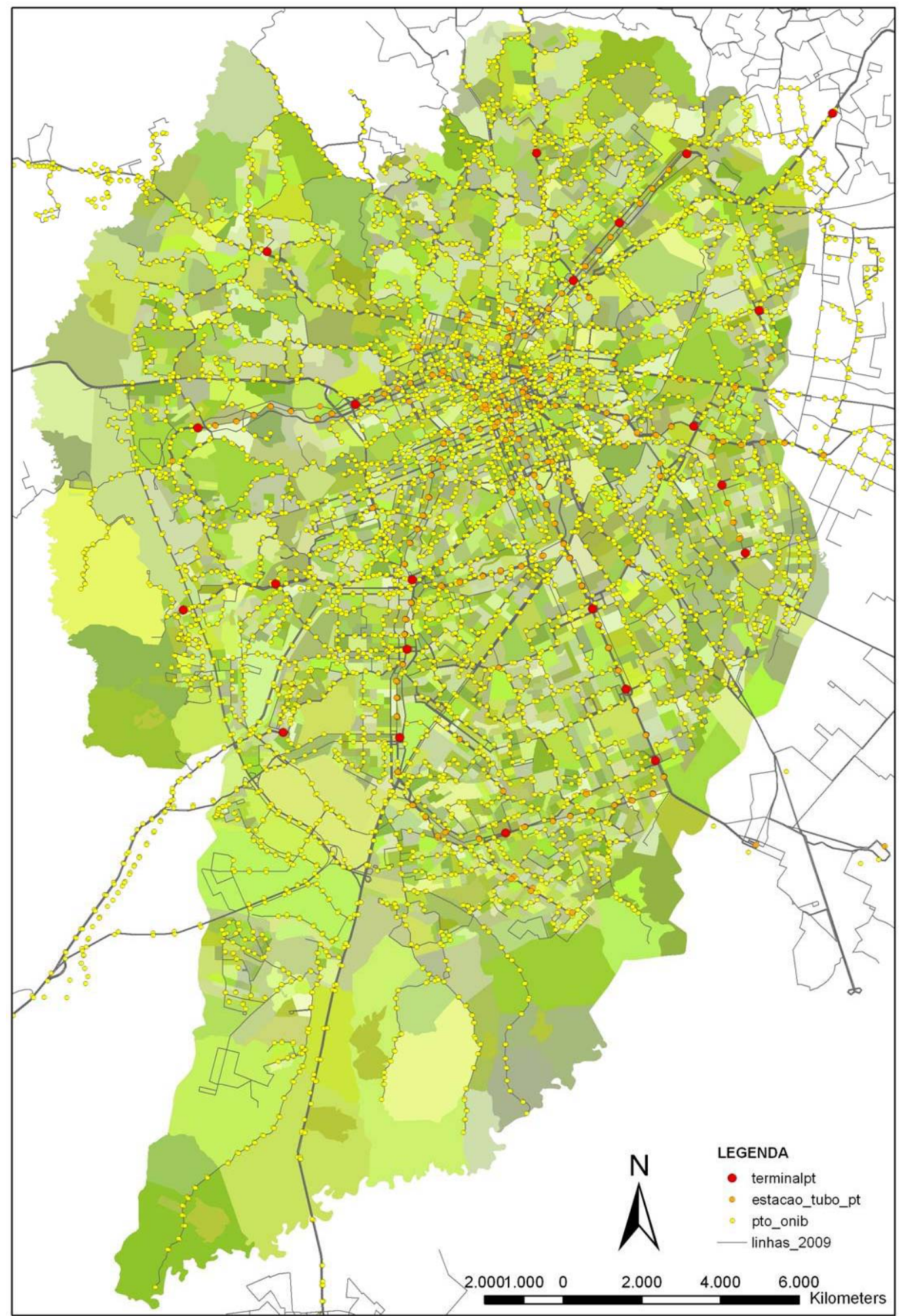

Figura 17: Dados geográficos: sistema de transporte público

Fonte: Adaptado de IPPUC (2009)

As informações fornecidas pela URBS foram principalmente aquelas relativas ao funcionamento do transporte público urbano, como: 
- Número de veículos que compõem a frota municipal e suas adaptações a pessoas com restrições de mobilidade;

- Despesas médias com transporte;

- Vagas em estacionamentos rotativos destinados a pessoas com restrições de mobilidade;

- Existência de campanhas educativas e de sensibilização destinadas à promoção da acessibilidade universal;

- Serviços e informações sobre a qualidade do tráfego urbano;

- Número de viagens realizadas nos terminais urbanos;

- Número de acidentes de trânsito e suas vítimas;

- Frequência do atendimento do transporte público;

- Número de viagens realizadas no sistema de transporte público urbano;

- Velocidade média operacional do sistema de transporte público;

- Quilometragem total percorrida pelo sistema de transporte público urbano.

Outra fonte municipal consultada foi a Secretaria de Finanças, que indicou a Lei municipal n¹3.073/09 que estima a receita e fixa a despesa do município de Curitiba para o exercício financeiro do ano de 2009. Esse documento foi utilizado para calcular:

- Recursos anuais disponíveis para investimentos em mobilidade urbana e projetos de transporte;

- Investimentos relacionados à provisão, melhoria e manutenção da infraestrutura, sistemas de transporte e mobilidade em todas as modalidades;

- Investimentos relacionados à provisão, melhoria e manutenção da infraestrutura para o transporte coletivo;

- Investimentos relacionados à provisão, melhoria e manutenção da infraestrutura para o transporte privado;

- Recursos anuais disponíveis para investimentos em meios motorizados;

- Recursos anuais disponíveis para investimentos em meios não motorizados.

A Secretaria Municipal de Educação forneceu informações sobre:

- Equipamentos de educação destinados à educação ambiental e desenvolvimento sustentável;

- Ações visando à educação e ao desenvolvimento sustentável; 
- Iniciativas educacionais e de conscientização sobre o desenvolvimento sustentável.

Finalmente a Secretaria Municipal do Meio Ambiente prestou-se a esclarecer sobre ruído de tráfego, através do Plano Municipal de Controle Ambiental e Desenvolvimento Sustentável.

As informações obtidas através do IBGE foram principalmente dados populacionais, como a projeção do número de habitantes e renda média mensal pessoal ou domiciliar. Da ANTP foi obtida a despesa média mensal com transporte público, pessoal ou domiciliar. O Anuário Estatístico da Agência Nacional do Petróleo (ANP) forneceu informações sobre a venda de combustíveis e o DETRAN/PR informou sobre as características da frota municipal.

\subsubsection{Cálculo dos indicadores}

O método de cálculo do IMUS é bastante diversificado e varia conforme o indicador. Alguns utilizam apenas informações espaciais e necessitam de um processamento avançado que cruza mapas com bases de dados. Outros dependem de informações diretas e simples, como a existência de alguma lei ou a adoção de alguma prática pelo gestor municipal. O método para o cálculo dos 87 indicadores é rigorosamente descrito no Guia de Indicadores do IMUS (COSTA, 2008), que estabelece para cada indicador:

- Definição;

- Unidade de medida;

- Referências;

- Relevância;

- Contribuição;

- Pesos;

- Dados de base;

- Fontes de dados;

- Método de cálculo;

- Normalização e avaliação. 
Para exemplificar o processo de cálculo do IMUS, os cálculos de dois dos seus indicadores são explicados a seguir.

\section{1) Indicador 1.1.1 Acessibilidade ao transporte público}

Segundo o Guia de Indicadores do IMUS (COSTA, 2008) esse indicador refere-se à porcentagem da população urbana residente na área de cobertura de um ponto de acesso aos serviços de transporte público, considerando todos os seus dispositivos. Os dados utilizados foram:

- Base georreferenciada localizando os pontos de ônibus e terminais, fornecida pelo IPPUC (2009);

- Base georreferenciada de Setores Censitários do IBGE, fornecida pelo IPPUC (2000).

O cálculo do indicador considerou a sobreposição das duas bases geográficas, através do uso do software TransCad, criando um buffer sobre os pontos de acesso do sistema de transporte. Para os pontos de ônibus convencionais utilizou-se um buffer com raio de 300 metros, e para terminais e estações tubo utilizou-se um raio de 500 metros, resultando na Figura 18. 


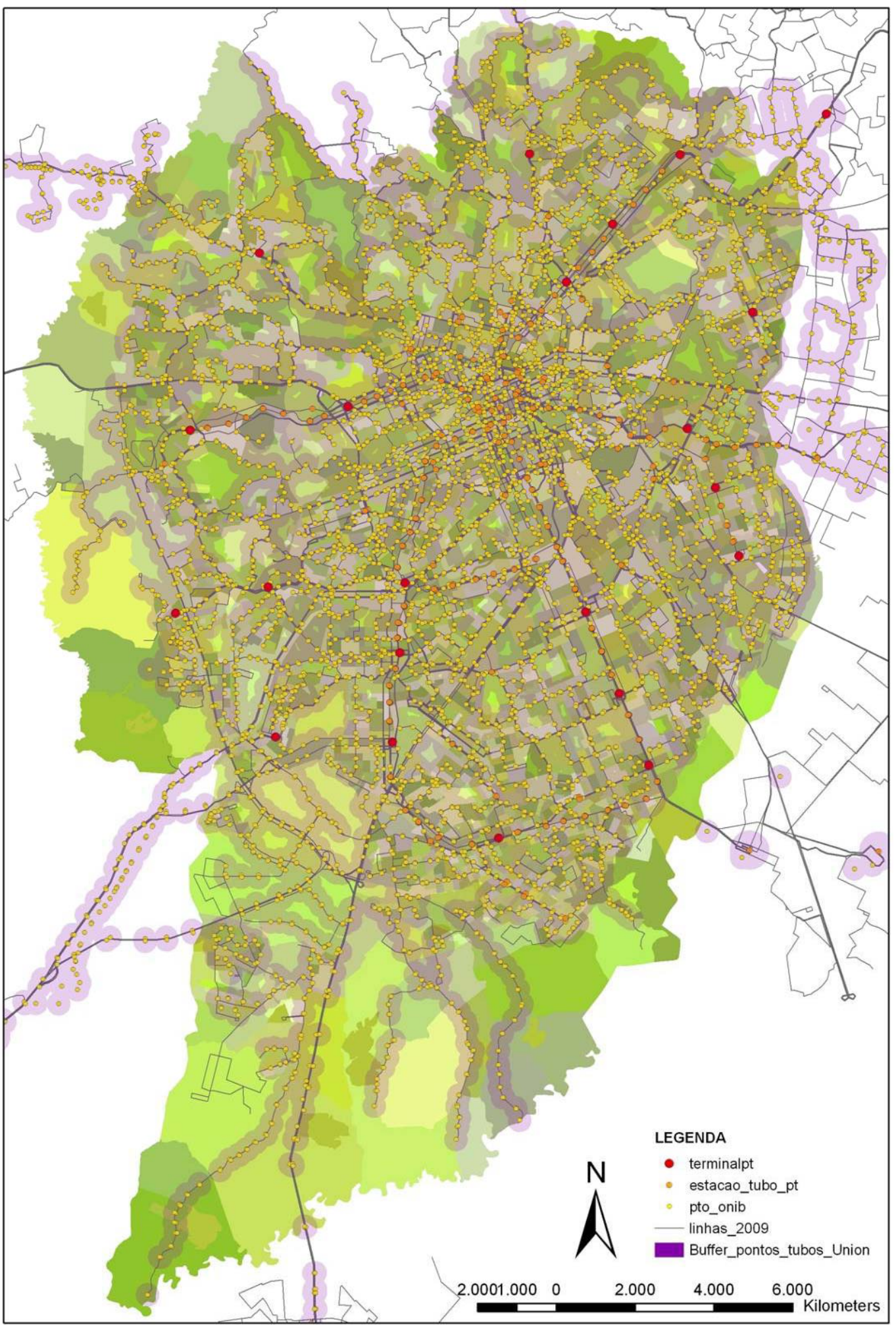

Figura 18: Cálculo do indicador Acessibilidade ao transporte público

Fonte: Adaptado de IPPUC (2009) 
O resultado do indicador é dado pela razão entre a população total atingida pela camada do buffer e pela população total do município. No caso os valores corresponderam a:

- Domicílios na área coberta pelo buffer. 455.970;

- Total de domicílios no município: 477.334.

O score obtido foi equivalente a 95,13\%, que corresponde a um valor normalizado de 0,95 .

\section{2) Indicador 7.8.1 Plano Diretor}

O Guia de Indicadores para o cálculo do IMUS (COSTA, 2008) define esse indicador como sendo a existência e ano de elaboração/atualização do Plano Diretor Municipal. Para o cálculo bastou realizar uma consulta à legislação municipal, através do site oficial da prefeitura, que revelou a existência da Lei Municipal $n^{\circ} 11.266 / 04$, que estabelece o Plano Diretor Municipal.

Como foi observado que Curitiba possui Plano Diretor implantado ou atualizado a menos de sete anos, o score obtido foi equivalente a 1,00, conforme normalização estabelecida.

\subsection{Avaliação de Desempenho}

O desempenho do índice global é facilmente avaliado, bastando observar o resultado obtido pelo cálculo do IMUS. O resultado do índice oscila de zero $(0,00)$ a um $(1,00)$, mas como sua aplicação ainda é limitada a apenas poucas cidades (São Carlos e Brasília), não se pode ao certo afirmar que determinado valor seja bom ou ruim. Porém, um resultado superior a 0,50 já corresponde a um aproveitamento um pouco superior ao valor intermediário da escala e isso, em teoria, equivale a um resultado positivo. 
O desempenho de cada domínio pode ser avaliado, desde que o mesmo seja considerado isoladamente em relação aos demais. A vantagem de considerar o resultado dos domínios é compreender a efetividade das políticas de mobilidade urbana em cada uma de suas grandes áreas de abrangência.

\subsection{Análise Intraurbana}

O cálculo do IMUS em Curitiba permite identificar os pontos fortes e fracos da mobilidade na cidade como um todo, porém não considera as suas variações ao longo do território municipal. Dessa forma procedeu-se a uma avaliação individualizada do índice, aplicada em cada uma das nove Regionais Administrativas da capital.

Para tanto foram identificados os indicadores que permitissem tal avaliação, ou seja, que possuam dados individualizados para as diferentes regiões da cidade. Assim, os indicadores utilizados foram os que associam seus cálculos a dados geográficos, uma vez que esses podem ser considerados dentro de limites específicos.

\subsection{Comparação entre Municípios}

O índice foi ainda utilizado como ferramenta de comparação entre diferentes municípios, Curitiba e São Carlos. Para isso foi necessário considerar os indicadores não calculados em cada uma das duas cidades. Isso é necessário, pois comparações são efetivas quando utilizam critérios de avaliação similares, assim, apenas os mesmos indicadores calculados foram considerados. 


\section{RESULTADOS}

Nesse capítulo são apresentados os resultados obtidos através da aplicação do método de cálculo do IMUS na cidade de Curitiba. Primeiramente é considerado o desempenho da cidade frente ao índice, analisando-se separadamente seus domínios e depois indicadores, possibilitando identificar os pontos mais fortes e também frágeis da mobilidade na cidade. Num segundo momento foram obtidos os resultados da aplicação do método em regiões distintas da mesma cidade, o que permitiu compreender os diferentes cenários da mobilidade no mesmo espaço urbano. Em seguida, deu-se destaque aos indicadores que demonstraram apresentar problemas quanto ao método de avaliação, demonstrando pontos de fragilidade na estrutura do índice. E finalmente o IMUS foi considerado como uma ferramenta para comparação entre cidades distintas.

\subsection{Estrutura do IMUS em Curitiba}

A avaliação da disponibilidade e qualidade das informações, que precedeu o cálculo do índice, permitiu reconhecer quais indicadores seriam efetivamente calculados. Informações de qualidade baixa ou obtidas em longo prazo não permitem sua aplicação no índice.

Do total de 87 indicadores que estruturam o IMUS, 75 possuem dados considerados de alta qualidade e obtidos em curto prazo. Além desses, quatro indicadores demonstraram possuir dados de qualidade média e obtidos em curto prazo. Os 79 indicadores citados foram, portanto, considerados passíveis de cálculo no índice, sendo que os oito remanescentes não se encontram disponíveis para tal. A Tabela 3 apresenta a estrutura do IMUS com a classificação dos indicadores conforme estabelecido na avaliação descrita. 
Tabela 3: Avaliação da disponibilidade e qualidade dos dados para o cálculo dos indicadores para a cidade de Curitiba

\begin{tabular}{|c|c|c|c|c|c|c|c|}
\hline \multirow{2}{*}{ DOMíNIOS } & \multicolumn{3}{|c|}{ DIMENSÕES } & \multirow{2}{*}{ TEMAS } & \multirow{2}{*}{ INDICADORES } & \multicolumn{2}{|c|}{ CLASSIFIC } \\
\hline & $\mathbf{s}$ & $\mathrm{E}$ & $\mathbf{A}$ & & & Disp & Qual \\
\hline \multirow{10}{*}{ 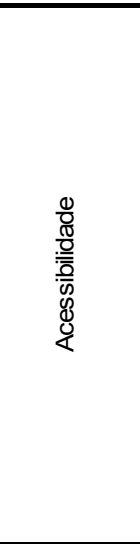 } & 0, & 0,36 & 0,26 & Acessibilidade aos sistemas & 1.1.1 Acessibilidade ao transporte público & $\mathrm{CP}$ & A \\
\hline & & & & de transporte & $\begin{array}{l}\text { Transporte público para pessoas com } \\
\text { necessidades especiais }\end{array}$ & $\mathrm{CP}$ & A \\
\hline & & & & & 1.1.3 Despesas com transportes & $\mathrm{CP}$ & A \\
\hline & 0,40 & 0,32 & 0,27 & Acessibilidade universal & $\begin{array}{l}\text { 1.2.1 Travessias adaptadas para pessoas com } \\
\text { necessidades especiais }\end{array}$ & $\mathrm{CP}$ & M \\
\hline & & & & & 1.2.2 Acessibilidade aos espaços abertos & $\mathrm{CP}$ & A \\
\hline & & & & & $\begin{array}{l}\text { 1.2.3 Vagas de estacionamento para pessoas } \\
\text { com necessidades especiais }\end{array}$ & $\mathrm{CP}$ & A \\
\hline & & & & & 1.2.4 Acessibilidade a edifícios públicos* ${ }^{*}$ & $\mathrm{CP}$ & A \\
\hline & & & & & 1.2.5 Acessibilidade aos serviços essenciais & $\mathrm{CP}$ & A \\
\hline & 0,38 & 0,30 & 0,32 & Barreiras físicas & 1.3.1 Fragmentação urbana & $\mathrm{CP}$ & A \\
\hline & 0,46 & 0,28 & 0,27 & $\begin{array}{l}\text { Legislação para pessoas com } \\
\text { necessidades especiais }\end{array}$ & 1.4.1 Ações para acessibilidade universal & $\mathrm{CP}$ & A \\
\hline \multirow{6}{*}{ 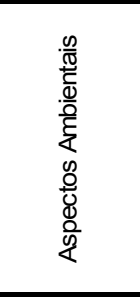 } & 0,29 & 0,28 & 0,43 & Controle dos impactos no meio & 2.1.1 Emissões de $\mathrm{CO}$ & $\mathrm{CP}$ & B \\
\hline & & & & ambiente & 2.1.2 Emissões de $\mathrm{CO}_{2}$ & $\mathrm{CP}$ & B \\
\hline & & & & & 2.1.3 População exposta ao ruído de tráfego & $\mathrm{CP}$ & M \\
\hline & & & & & 2.1.4 Estudos de impacto ambiental & $\mathrm{CP}$ & A \\
\hline & 0,26 & 0,32 & 0,42 & Recursos naturais & 2.2.1 Consumo de combustível & $\mathrm{CP}$ & M \\
\hline & & & & & $\begin{array}{l}\text { Uso de energia limpa e combustíveis } \\
\text { alternativos }\end{array}$ & $\mathrm{CP}$ & A \\
\hline \multirow{5}{*}{ 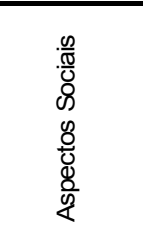 } & 0,40 & 0,31 & 0,29 & Apoio ao cidadão & 3.1.1 Informação disponível ao cidadão & $\mathrm{CP}$ & A \\
\hline & 0,45 & 0,30 & 0,25 & Inclusão social & 3.2.1 Equidade vertical (renda) & MP & B \\
\hline & 0,39 & 0,30 & 0,31 & Educação e cidadania & $\begin{array}{l}\text { 3.3.1 Educação para o desenvolvimento } \\
\text { sustentável }\end{array}$ & $\mathrm{CP}$ & A \\
\hline & 0,41 & 0,27 & 0,32 & Participação popular & 3.4.1 Participação na tomada de decisão & $\mathrm{CP}$ & A \\
\hline & 0,35 & 0,30 & 0,35 & $\underline{\text { Qualidade de vida }}$ & 3.5.1 Qualidade de vida & $\mathrm{CP}$ & A \\
\hline \multirow{7}{*}{ 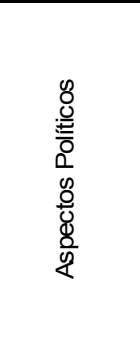 } & 0,33 & 0,34 & 0,32 & Integração de ações políticas & 4.1.1 Integração entre níveis de governo & $\mathrm{CP}$ & A \\
\hline & & & & & 4.1.2 Parcerias público-privadas & $\mathrm{CP}$ & A \\
\hline & 0,33 & 0,40 & 0,27 & Captação e gerenciamento de & 4.2.1 Captação de recursos & $\mathrm{CP}$ & A \\
\hline & & & & recursos & 4.2.2 Investimentos em sistemas de transporte & $\mathrm{CP}$ & A \\
\hline & & & & & $\begin{array}{l}\text { 4.2.3 } \begin{array}{l}\text { Distribuição dos recursos (coletivo } x \\
\text { privado) }\end{array}\end{array}$ & $\mathrm{CP}$ & A \\
\hline & & & & & $\begin{array}{l}\text { 4.2.4 Distribuição dos recursos (motorizados } x \\
\text { não motorizados) }\end{array}$ & $\mathrm{CP}$ & A \\
\hline & 0,34 & 0,33 & 0,32 & Política de mobilidade urbana & 4.3.1 Política de mobilidade urbana & $\mathrm{CP}$ & A \\
\hline \multirow{5}{*}{ 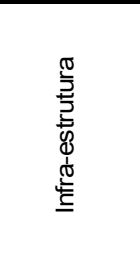 } & 0,28 & 0,41 & 0,31 & Provisão e manutenção da & 5.1.1 Densidade e conectividade da rede viária & $\mathrm{CP}$ & A \\
\hline & & & & infraestrutura de transportes & 5.1.2 Vias pavimentadas & $\mathrm{CP}$ & A \\
\hline & & & & & $\begin{array}{l}\text { 5.1.3 Despesas com manutenção da } \\
\text { infraestrutura }\end{array}$ & $\mathrm{CP}$ & A \\
\hline & & & & & 5.1.4 Sinalização viária* & $\mathrm{CP}$ & A \\
\hline & 0,33 & 0,35 & 0,33 & $\begin{array}{l}\text { Distribuição da infraestrutura } \\
\text { de transporte }\end{array}$ & 5.2.1 Vias para transporte coletivo & $\mathrm{CP}$ & A \\
\hline \multirow{9}{*}{ 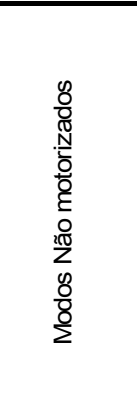 } & 0,32 & 0,29 & 0,39 & Transporte cicloviário & 6.1.1 Extensão e conectividade de ciclovias & $\mathrm{CP}$ & A \\
\hline & & & & & 6.1.2 Frotas de bicicletas & $\mathrm{CP}$ & A \\
\hline & & & & & 6.1.3 Estacionamento de bicicletas & $\mathrm{CP}$ & A \\
\hline & 0,33 & 0,28 & 0,39 & Deslocamentos a pé & 6.2.1 Vias para pedestres & $\mathrm{CP}$ & A \\
\hline & & & & & 6.2.2 Vias com calçadas & $\mathrm{CP}$ & A \\
\hline & 0,28 & 0,32 & 0,40 & Redução de viagens & 6.3.1 Distância de viagem & LP & $\mathrm{B}$ \\
\hline & & & & & 6.3.2 Tempo de viagem & LP & B \\
\hline & & & & & 6.3.3 Número de viagens & LP & B \\
\hline & & & & & 6.3.4 Ações para redução do tráfego motorizado & $\mathrm{CP}$ & A \\
\hline
\end{tabular}

*Indicadores que possuem dados para o cálculo, mas não foram disponibilizados pelo gestor. 
Tabela 3: (continuação) Avaliação da disponibilidade e qualidade dos dados para o cálculo dos indicadores

\begin{tabular}{|c|c|c|c|c|c|c|c|}
\hline \multirow{2}{*}{ DOMíNIOS } & \multicolumn{3}{|c|}{ DIMENSÕES } & \multirow{2}{*}{ TEMAS } & \multirow{2}{*}{ INDICADORES } & \multicolumn{2}{|c|}{ CLASSIFC } \\
\hline & $\mathbf{s}$ & $\mathrm{E}$ & A & & & Disp & Qual \\
\hline \multirow{18}{*}{ 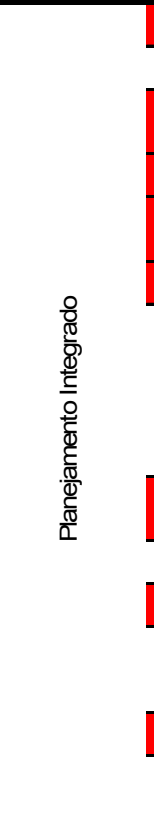 } & 0,31 & 0,37 & 0,32 & Capacitação de gestores & 7.1.1 Nível de formação de técnicos e gestores & $\mathrm{CP}$ & A \\
\hline & & & & & 7.1.2 Capacitação de técnicos e gestores & $\mathrm{CP}$ & A \\
\hline & & 0,30 & 0,35 & $\begin{array}{l}\text { Áreas centrais e de interesse } \\
\text { histórico }\end{array}$ & 7.2.1 Vitalidade do centro & $\mathrm{CP}$ & A \\
\hline & 0,31 & 0,34 & 0,35 & Integração regional & 7.3.1 Consórcios intermunicipais & $\mathrm{CP}$ & A \\
\hline & & 0,32 & 0,31 & $\begin{array}{l}\text { Transparência do processo } \\
\text { de planejamento }\end{array}$ & 7.4.1 Transparência e responsabilidade & $\mathrm{CP}$ & A \\
\hline & 0,3 & 0,32 & 0,36 & Planejamento e controle do & 7.5.1 Vazios urbanos & $\mathrm{CP}$ & A \\
\hline & & & & uso e ocupação do solo & 7.5.2 Crescimento urbano & $\mathrm{CP}$ & A \\
\hline & & & & & 7.5.3 Densidade populacional urbana & $\mathrm{CP}$ & $A$ \\
\hline & & & & & 7.5.4 Índice de uso misto & $\mathrm{CP}$ & A \\
\hline & & & & & 7.5.5 Ocupações irregulares & $\mathrm{CP}$ & A \\
\hline & 0,32 & 0,35 & 0,33 & $\begin{array}{l}\text { Planejamento estratégico e } \\
\text { integrado }\end{array}$ & $\begin{array}{l}\text { Planejamento urbano, ambiental e de } \\
\text { transporte integrado }\end{array}$ & $\mathrm{CP}$ & A \\
\hline & & & & & 7.6.2 Efetivação e continuidade das ações & $\mathrm{CP}$ & A \\
\hline & & 0,39 & 0,30 & Planejamento da infraestrutura & 7.7.1 Parques e áreas verdes & $\mathrm{CP}$ & $\bar{A}$ \\
\hline & & & & urbana e equipamentos & 7.7.2 Equipamentos urbanos (escolas) & $\mathrm{CP}$ & A \\
\hline & & & & & 7.7.3 Equipamentos urbanos (postos de saúde) & $\mathrm{CP}$ & A \\
\hline & & 0,35 & 0,35 & Plano diretor e legislação & 7.8.1 Plano diretor & $\mathrm{CP}$ & A \\
\hline & & & & urbanística & 7.8.2 Legislação urbanística & $\mathrm{CP}$ & A \\
\hline & & & & & 7.8.3 Cumprimento da legislação urbanística & $\mathrm{CP}$ & A \\
\hline \multirow{9}{*}{ 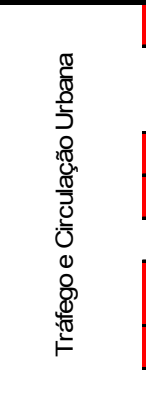 } & & 0,38 & 0,26 & Acidentes de trânsito & 8.1.1 Acidentes de trânsito & $\mathrm{CP}$ & A \\
\hline & & & & & 8.1.2 Acidentes com pedestres e ciclistas & $\mathrm{CP}$ & A \\
\hline & & & & & 8.1.3 Prevenção de acidentes & $\mathrm{CP}$ & A \\
\hline & 0,39 & 0,31 & 0,30 & Educação para o trânsito & 8.2.1 Educação para o trânsito & $\mathrm{CP}$ & A \\
\hline & 0,29 & 0,35 & 0,36 & Fluidez e circulação & 8.3.1 Congestionamento* & $\mathrm{CP}$ & A \\
\hline & & & & & 8.3.2 Velocidade média do tráfego & $\mathrm{CP}$ & M \\
\hline & 0,34 & 0,33 & 0,33 & $\begin{array}{l}\text { Operação e fiscalização de } \\
\text { trânsito }\end{array}$ & 8.4.1 Violação das leis de trânsito & $\mathrm{CP}$ & A \\
\hline & 0,32 & 0,31 & 0,36 & Transporte individual & 8.5.1 Índice de motorização & $\mathrm{CP}$ & A \\
\hline & & & & & 8.5.2 Taxa de ocupação de veículos & $\mathrm{CP}$ & A \\
\hline \multirow{18}{*}{ 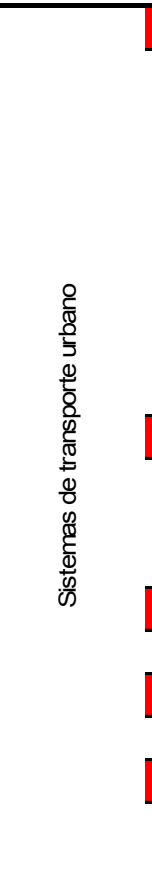 } & & 0,33 & 0,32 & Disponibilidade e qualidade do & 9.1.1 Extensão da rede transporte público & $\mathrm{CP}$ & $\bar{A}$ \\
\hline & & & & transporte público & $\begin{array}{l}\text { 9.1.2 Frequência de atendimento do transporte } \\
\text { público }\end{array}$ & $\mathrm{CP}$ & A \\
\hline & & & & & 9.1.3 Pontualidade & $\mathrm{CP}$ & A \\
\hline & & & & & 9.1.4 Velocidade média do transporte público & $\mathrm{CP}$ & A \\
\hline & & & & & 9.1.5 Idade média da frota de transporte público & $\mathrm{CP}$ & A \\
\hline & & & & & 9.1.6 Índice de passageiros por quilômetro & $\mathrm{CP}$ & A \\
\hline & & & & & 9.1.7 Passageiros transportados anualmente & $\mathrm{CP}$ & A \\
\hline & & & & & $\begin{array}{l}\text { 9.1.8 Satisfação do usuário com o serviço de } \\
\text { transporte público }\end{array}$ & $\mathrm{CP}$ & A \\
\hline & 0,31 & 0,34 & 0,34 & Diversificação modal & 9.2.1 Diversidade de modos de transporte & $\mathrm{CP}$ & A \\
\hline & & & & & 9.2.2 Transporte coletivo $x$ transporte individual & LP & B \\
\hline & & & & & $\begin{array}{l}\text { 9.2.3 Modos não motorizados x modos } \\
\text { motorizados }\end{array}$ & LP & B \\
\hline & & 0,35 & 0,31 & Regulação e fiscalização do & 9.3.1 Contratos e licitações & $\mathrm{CP}$ & A \\
\hline & & & & transporte público & 9.3.2 Transporte clandestino & $\mathrm{CP}$ & A \\
\hline & 0,37 & 0,33 & 0,30 & Integração do transporte & 9.4.1 Terminais intermodais & $\overline{\mathrm{CP}}$ & $\bar{A}$ \\
\hline & & & & publico & 9.4.2 Integração do transporte público & $\mathrm{CP}$ & A \\
\hline & & 0,37 & 0,35 & Política tarifária & 9.5.1 Descontos e gratuidades & $\mathrm{CP}$ & $\bar{A}$ \\
\hline & & & & & 9.5.2 Tarifas de transporte & $\mathrm{CP}$ & A \\
\hline & & & & & 9.5.3 Subsídios públicos & $\mathrm{CP}$ & A \\
\hline
\end{tabular}

*Indicadores que possuem dados para o cálculo, mas não foram disponibilizados pelo gestor. 
No entanto, é essencial afirmar que algumas das informações consideradas de alta qualidade e obtidas em curto prazo não se encontraram disponíveis para o cálculo de seus respectivos indicadores. Apesar de esses dados existirem, em algumas situações o órgão ou técnico responsável não se encontrou acessível (disponível) para fornecêlos. Dessa forma, o número de indicadores efetivamente calculados difere do número de indicadores avaliados positivamente pela qualidade e disponibilidade.

O cálculo do IMUS em Curitiba foi realizado para 75 indicadores do total de 87 que compõem sua estrutura. A falta de dados necessários, ou a indisponibilidade de contato com os responsáveis pela gerência das informações inviabilizou o uso de sua estrutura original integralmente. Os dados não encontrados (ver Tabela 4) equivalem a informações das mais diversas naturezas, refletindo em sete dos nove domínios que constituem o índice. Somente os domínios Aspectos Políticos e Planejamento Integrado foram inteiramente considerados no cálculo. Deve-se considerar que um dos indicadores calculados (Nível de formação de técnicos e gestores) teve seu valor estimado.

Dos 12 indicadores não calculados em Curitiba, seis refletem a ausência de uma Pesquisa de Origem e Destino. Utilizada como ferramenta de planejamento capaz de identificar os padrões de deslocamento da população, a Pesquisa de Origem e Destino normalmente é utilizada por gestores na tomada de decisões. No entanto, em Curitiba o planejamento deu-se de forma diferenciada, sendo realizado em longo prazo, de tal maneira que a execução dos sucessivos planos diretores ultrapassou as várias administrações políticas (LINDAU et al., 2010). Dessa forma a cidade condicionou a demanda por transporte ao uso do solo urbano e direcionou as linhas de desejo para as áreas com melhor infraestrutura. Essa conquista deve-se à existência de órgãos de gerência e planejamento fortes e atuantes, como o IPPUC e a URBS, que trabalham de forma a garantir a continuidade das propostas mesmo durante as transições de governo.

Mesmo garantindo um bom planejamento sem o uso da Pesquisa de Origem e Destino, informações importantes como distâncias percorridas e tempos de viagens jamais foram obtidas, refletindo no desconhecimento das principais características das viagens realizadas na cidade. 
Tabela 4: Indicadores do IMUS que não foram calculados em Curitiba

\begin{tabular}{lc}
\hline \multicolumn{1}{c}{ DOMÍNIO } & INDICADOR \\
\hline ACESSIBILIDADE & Acessibilidade a edifícios públicos \\
\hline ASPECTOS AMBIENTAIS & Emissões de CO \\
\hline ASPECTOS SOCIAIS & Emissões de $\mathrm{CO}_{2}$ \\
\hline INFRAESTRUTURA & Equidade vertical (renda) \\
\hline & Sinalização viária \\
MODOS NÃO MOTORIZADOS & Distância de viagem \\
\hline TRÁFEGO E CIRCULAÇÃO URBANA & Tempo de viagem \\
\hline SISTEMA DE TRANSPORTE URBANO & Número de viagens \\
\hline
\end{tabular}

A falta dos indicadores mencionados resultou na indisponibilidade de considerar um dos 37 temas que compõem o índice:

- Inclusão Social (ASPECTOS SOCIAIS);

\subsection{Desempenho do IMUS em Curitiba}

Utilizando-se os 75 indicadores disponíveis e considerando os demais como não avaliados, o resultado obtido para o IMUS global e setorial é apresentado na Tabela 5.

Tabela 5: Resultados do IMUS global e setorial

\begin{tabular}{|c|c|}
\hline DIMENSÃO DO IMUS & VALOR NORMALIZADO \\
\hline IMUS Global & 0,754 \\
\hline IMUS Social & 0,255 \\
\hline IMUS Econômica & 0,250 \\
\hline IMUS Ambiental & 0,249 \\
\hline
\end{tabular}

Fonte: Adaptado de cosTA (2008)

O aproveitamento equivalente a $75 \%$ encontra-se acima do valor intermediário, para uma escala que varia de 0,00 a 1,00. Isso mostra que muitos aspectos da mobilidade 
em Curitiba seguem os princípios da sustentabilidade, embora ainda alguns necessitem ser melhorados.

Das três dimensões que estruturam o índice, a dimensão Social obteve ligeira predominância sobre as demais. É importante considerar que a variação entre as dimensões é muito pequena, situação já esperada, pois reflete um equilíbrio de valores sugerido desde o desenvolvimento do método, através do painel de especialistas que atribuiu os pesos de cada dimensão.

\subsubsection{Valores não calculados}

É possível estimar valores para os indicadores não calculados, realizando assim uma simulação do comportamento do índice, caso os mesmos tivessem sido aplicados. Sendo assim, foram consideradas duas possíveis situações:

1) Estimativa dos possíveis valores de cada indicador (os scores dos indicadores não calculados foram estimados);

2) Valores máximos para cada indicador (os scores dos indicadores não calculados foram considerados como sendo 1,00).

Essas duas situações correspondem a uma possível condição real e também ideal para o grupo de indicadores não calculados. Os resultados encontrados nas duas simulações são apresentados na Tabela 6.

Tabela 6: Simulações para indicadores não calculados

\begin{tabular}{lccc}
\hline $\begin{array}{c}\text { DIMENSÃO DO } \\
\text { IMUS }\end{array}$ & $\begin{array}{c}\text { VALOR } \\
\text { NORMALIZADO* }\end{array}$ & SCORES ESTIMADOS** & SCORES MÁXIMOS*** \\
\hline IMUS Global & 0,754 & 0,711 & 0,792 \\
\hline IMUS Social & 0,255 & 0,242 & 0,268 \\
\hline IMUS Econômica & 0,250 & 0,237 & 0,263 \\
\hline IMUS Ambiental & 0,249 & 0,232 & 0,261 \\
\hline
\end{tabular}

${ }^{*}$ Obtido pelo cálculo dos 75 indicadores disponíveis.

**Obtido pelo cálculo dos 75 indicadores disponíveis e dos 12 indicadores (não disponíveis) com valores estimados.

***Obtido pelo cálculo dos 75 indicadores disponíveis e dos 12 indicadores (não disponíveis) com valores máximos.

Fonte: Adaptado de Costa (2008) 
As duas situações aproximam-se muito do quadro real verificado pelo resultado do IMUS de Curitiba (Tabela 5 ou coluna 2 da Tabela 6). Curiosamente o valor do índice sem a consideração dos valores não calculados se aproxima da média das duas estimativas, o que indica um interessante equilíbrio entre cenários extremos. Cabe ressaltar que os valores obtidos nas três dimensões setoriais (Social, Econômica e Ambiental) continuam a não sofrer grandes variações.

A análise dos resultados do IMUS, apresentada na sequência, considera apenas os valores disponíveis para o cálculo (dos 75 indicadores), excluindo as estimativas dos scores para indicadores não calculados.

\subsection{Desempenho dos Domínios}

O resultado obtido em cada domínio que constitui o IMUS foi analisado individualmente, o que permite uma avaliação preliminar do desempenho da cidade. Essa comparação foi realizada através do cálculo individualizado de cada domínio, considerando todos os demais indicadores como vazios. Assim, o resultado obtido

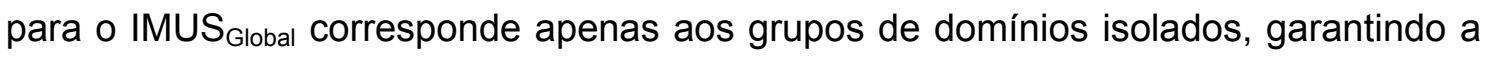
comparação entre as áreas distintas.

O resultado obtido em cada um dos nove domínios é apresentado na Figura 19. Sua análise indica que a maioria obteve um desempenho acima da média, sendo que apenas um deles, Modos NÃO MOTORIZADOS, ficou com desempenho inferior a 0,5. Quanto aos domínios de scores mais elevados destacam-se INFRAESTRUTURA, Aspectos SociaIS e PLANEJAMENTO INTEGRADO. 


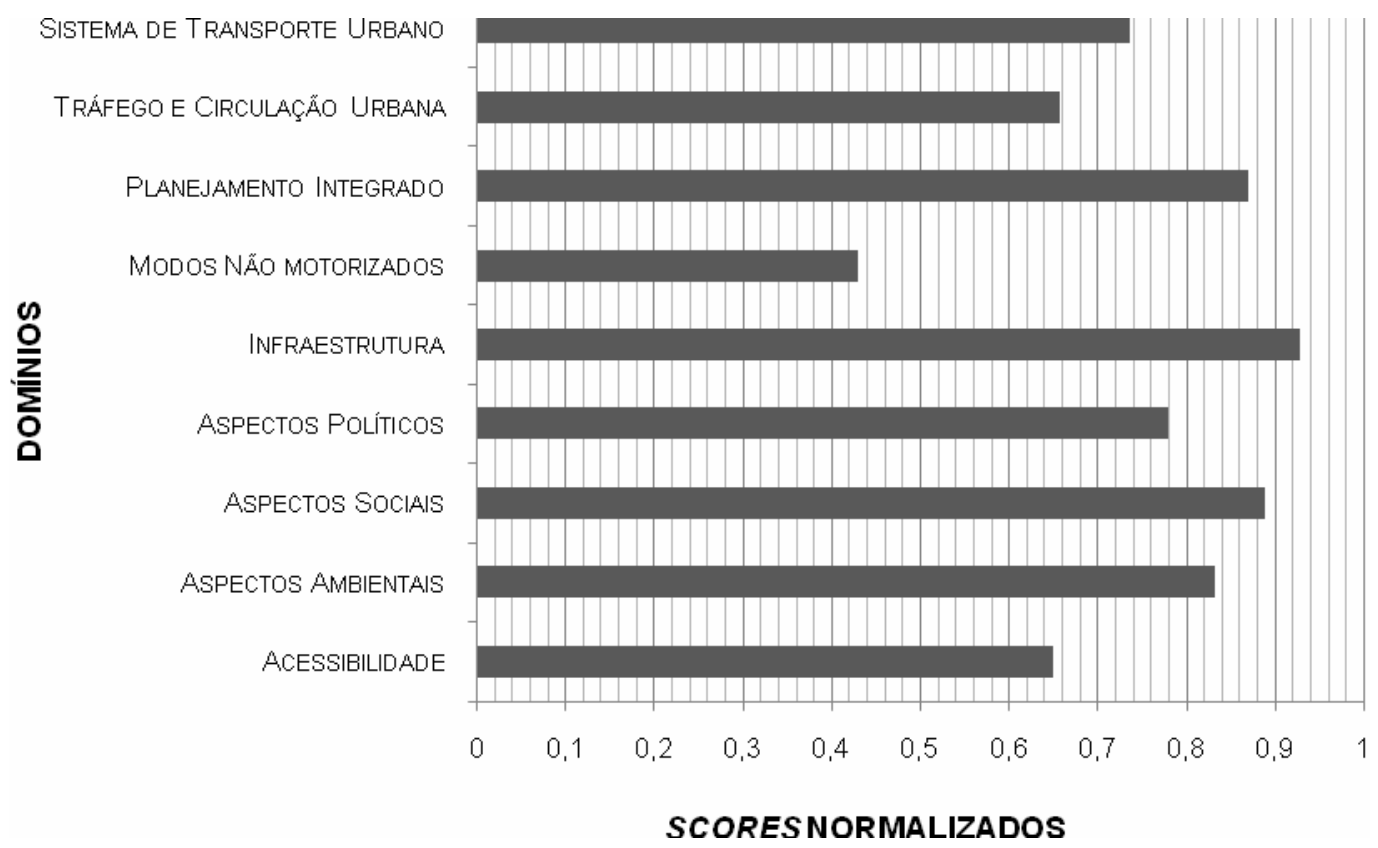

Figura 19: Desempenho dos domínios do IMUS

O entendimento dos resultados obtidos para cada domínio será dado com a análise específica dos indicadores, apresentada a seguir.

\subsection{Desempenho dos Indicadores}

Embora o IMUS seja composto por 87 indicadores, apenas 75 foram calculados em Curitiba, sendo que, desse total, 33 (44\%) atingiram score máximo equivalente a 1,00 e seis ( $8 \%$ ) obtiveram score zero. Essa comparação é bastante favorável para a cidade, pois demonstra clara preocupação com a mobilidade sustentável.

Desconsiderando os desempenhos extremos dos indicadores, 52 obtiveram resultado superior a 0,70, além de seis indicadores com scores entre 0,40 e 0,70. Isso significa que $77 \%$ do total de 75 indicadores obtiveram resultados bons ou excelentes. Esses resultados podem ser facilmente identificados observando-se a Figura 20, que mostra, através do uso de cores, o desempenho dos indicadores calculados. A cor verde foi utilizada para identificar os resultados obtidos acima do score 0,70. A cor amarela identifica os valores intermediários, entre 0,40 e 0,70, e a cor vermelha os indicadores com resultados ruins, de zero a 0,40 . No entanto, é fundamental considerar as 
condições mais críticas, representadas pela ausência de barras no gráfico. Essas lacunas identificam os indicadores com score zero, equivalendo aos indicadores de piores resultados.

Como alguns dos indicadores não foram calculados, esses foram identificados pela referência ao score VAZIO. Nesse caso é importante considerar que os pesos desses indicadores são considerados zero, redistribuindo-se assim os pesos entre os indicadores passíveis de cálculo, agrupados no mesmo tema. Também se deve tomar o cuidado para não confundir esses indicadores com os que foram calculados, mas obtiveram resultado zero, pois os primeiros não interferiram de forma direta no resultado do cálculo realizado, mas os segundos contribuíram para a redução no valor do índice final da cidade.

Os resultados encontrados no cálculo de cada indicador são apresentados na Tabela 7. 


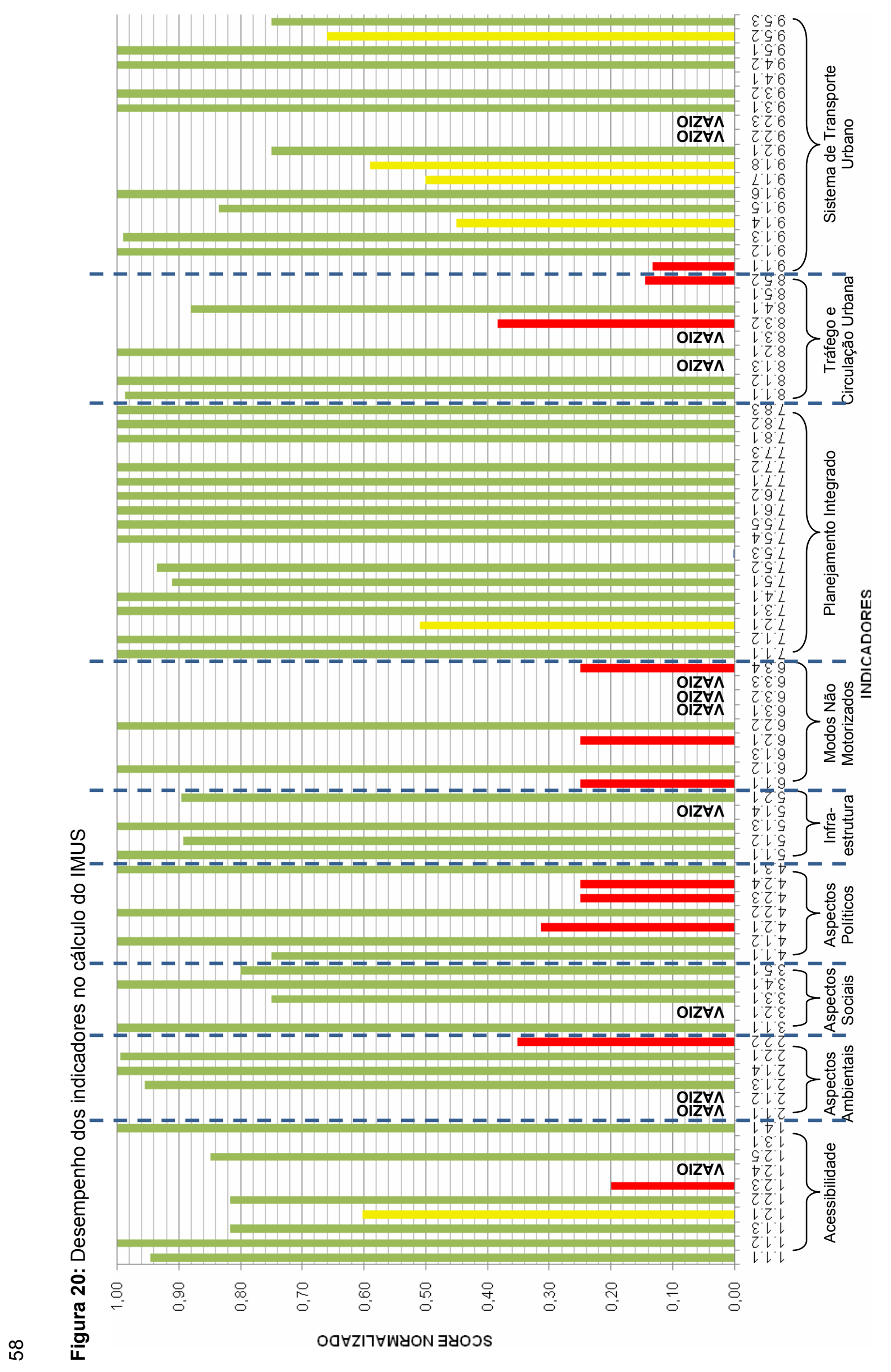


Tabela 7: Desempenho dos indicadores no cálculo do IMUS

\begin{tabular}{|c|c|c|c|c|c|c|c|}
\hline \multirow{2}{*}{$\begin{array}{c}\text { DOMíNIO } \\
\text { (peso) }\end{array}$} & \multicolumn{3}{|c|}{ DIMENSÕES } & \multirow{2}{*}{ TEMAS (peso) } & \multirow{2}{*}{ INDICADORES } & \multirow{2}{*}{ PESO } & \multirow{2}{*}{ SCORE } \\
\hline & $\mathbf{s}$ & $\mathrm{E}$ & $\mathbf{A}$ & & & & \\
\hline \multirow{11}{*}{ 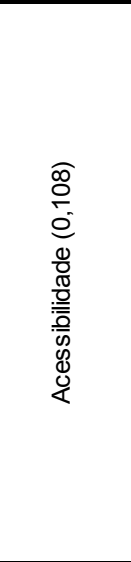 } & & 0,36 & 0,26 & Acessibilidade aos sistemas & 1.1.1 Acessibilidade ao transporte público & 0,33 & 0,95 \\
\hline & & & & de transporte $(0,29)$ & $\begin{array}{l}\text { Transporte público para pessoas com } \\
\text { necessidades especiais }\end{array}$ & 0,33 & 1 \\
\hline & & & & & 1.1.3 Despesas com transportes & 0,33 & 0,82 \\
\hline & 0,40 & 0,32 & 0,27 & $\begin{array}{l}\text { Acessibilidade universal } \\
(0,28)\end{array}$ & $\begin{array}{l}\text { 1.2.1 Travessias adaptadas para pessoas com } \\
\text { necessidades especiais }\end{array}$ & 0,25 & 0,6 \\
\hline & & & & & 1.2.2 Acessibilidade aos espaços abertos & 0,25 & 0,82 \\
\hline & & & & & $\begin{array}{l}\text { 1.2.3 Vagas de estacionamento para pessoas } \\
\text { com necessidades especiais }\end{array}$ & 0,25 & 0,2 \\
\hline & & & & & 1.2.4 Acessibilidade a edifícios públicos & $-^{*}$ & VAZIO \\
\hline & & & & & 1.2.5 Acessibilidade aos serviços essenciais & 0,25 & 0,85 \\
\hline & & 0,30 & 0,32 & Barreiras físicas $(0,22)$ & 1.3.1 Fragmentação urbana & 1 & 0 \\
\hline & & & & Legislação para pessoas com & & & \\
\hline & 46 & 0,28 & 0,27 & $\frac{\text { necessidades especiais }}{(0,21)}$ & 1.4.1 Ações para acessibilidade universal & 1 & 1 \\
\hline \multirow{6}{*}{ 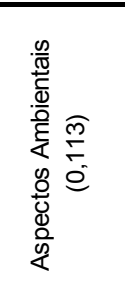 } & & 0,28 & 0,43 & Controle dos impactos no meio & 2.1.1 Emissões de CO & $--^{*}$ & VAZIO \\
\hline & & & & ambiente $(0,52)$ & 2.1.2 Emissões de $\mathrm{CO}_{2}$ & $-{ }^{*}$ & VAZIO \\
\hline & & & & & 2.1.3 População exposta ao ruído de tráfego & 0,5 & 0,96 \\
\hline & & & & & 2.1.4 Estudos de impacto ambiental & 0,5 & 1 \\
\hline & & 0,32 & 0,42 & Recursos naturais $(0,48)$ & 2.2.1 Consumo de combustível & 0,5 & 0,99 \\
\hline & & & & & $\begin{array}{l}\text { Uso de energia limpa e combustiveis } \\
\text { alternativos }\end{array}$ & 0,5 & 0,35 \\
\hline \multirow{5}{*}{ 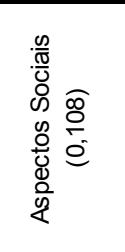 } & 0,40 & 0,31 & 0,29 & Apoio ao cidadão $(0,26)$ & 3.1.1 Informação disponível ao cidadão & 1 & 1 \\
\hline & 0,45 & 0,30 & 0,25 & Inclusão social $(0,00)$ & 3.2.1 Equidade vertical (renda) & $--^{*}$ & VAZIO \\
\hline & 39 & 0,30 & 0,31 & Educação e cidadania 0,23 ) & $\begin{array}{l}\text { 3.3.1 Educação para o desenvolvimento } \\
\text { sustentável }\end{array}$ & 1 & 0,75 \\
\hline & 0,41 & 0,27 & 0,32 & Participação popular $(0,24)$ & 3.4.1 Participação na tomada de decisão & 1 & 1 \\
\hline &, 35 & 0,30 & 0,35 & Qualidade de vida $(0,27)$ & 3.5.1 Qualidade de vida & 1 & 0,8 \\
\hline \multirow{7}{*}{ 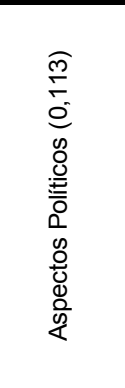 } & & 0,34 & 0,32 & Integração de ações políticas & 4.1.1 Integração entre níveis de governo & 0,5 & 0,75 \\
\hline & & & & & 4.1.2 Parcerias público-privadas & 0,5 & 1 \\
\hline & ,33 & 0,40 & 0,27 & Captação e gerenciamento de & 4.2.1 Captação de recursos & 0,25 & 0,31 \\
\hline & & & & recursos $(0,33)$ & 4.2.2 Investimentos em sistemas de transporte & 0,25 & 1 \\
\hline & & & & & $\begin{array}{l}\text { 4.2.3 } \begin{array}{l}\text { Distribuição dos recursos (coletivo } x \\
\text { privado) }\end{array}\end{array}$ & 0,25 & 0,25 \\
\hline & & & & & $\begin{array}{l}\text { 4.2.4 } \begin{array}{l}\text { Distribuição dos recursos (motorizados } x \\
\text { não motorizados) }\end{array}\end{array}$ & 0,25 & 0,25 \\
\hline & 34 & 0,33 & 0,32 & $\begin{array}{l}\text { Política de mobilidade urbana } \\
(0,34)\end{array}$ & 4.3.1 Política de mobilidade urbana & 1 & 1 \\
\hline \multirow{5}{*}{ 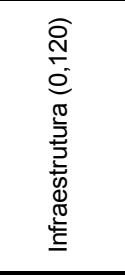 } & , 28 & 0,41 & 0,31 & Provisão e manutenção da & 5.1.1 Densidade e conectividade da rede viária & 0,33 & 1 \\
\hline & & & & - infraestrutura de transportes & 5.1.2 Vias pavimentadas & 0,33 & 0,89 \\
\hline & & & & & $\begin{array}{l}\text { 5.1.3 Despesas com manutenção da } \\
\text { infraestrutura }\end{array}$ & 0,33 & 1 \\
\hline & & & & & 5.1.4 Sinalização viária & $-{ }^{*}$ & VAZIO \\
\hline & ,33 & 0,35 & 0,33 & $\begin{array}{l}\text { Distribuição da infraestrutura } \\
\text { de transporte }(0,54)\end{array}$ & 5.2.1 Vias para transporte coletivo & 1 & 0,9 \\
\hline \multirow{9}{*}{ 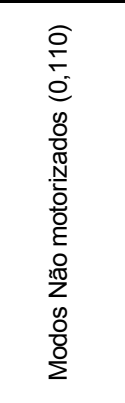 } &, 02 & 0,29 & 0,39 & Transporte cicloviário $(0,31)$ & 6.1.1 Extensão e conectividade de ciclovias & 0,33 & 0,25 \\
\hline & & & & & 6.1.2 Frotas de bicicletas & 0,33 & 1 \\
\hline & & & & & 6.1.3 Estacionamento de bicicletas & 0,33 & 0 \\
\hline & & 0,28 & 0,39 & Modos não motorizados $(0,34)$ & 6.2.1 Vias para pedestres & 0,5 & 0,25 \\
\hline & & & & & 6.2.2 Vias com calçadas & 0,5 & 1 \\
\hline &,,$<$, & 0,32 & 0,40 & Redução de viagens $(0,35)$ & 6.3.1 Distância de viagem & $--^{*}$ & VAZIO \\
\hline & & & & & 6.3.2 Tempo de viagem & $-{ }^{*}$ & VAZIO \\
\hline & & & & & 6.3.3 Número de viagens & $-{ }^{*}$ & VAZIO \\
\hline & & & & & 6.3.4 Ações para redução do tráfego motorizado & 1 & 0,25 \\
\hline
\end{tabular}

*Peso zero pela inexistência de dados, redistribuído para os demais indicadores do mesmo tema. Fonte: Costa (2008) 
Tabela 7: (continuação) Desempenho dos indicadores no cálculo do IMUS

\begin{tabular}{|c|c|c|c|c|c|c|c|}
\hline \multirow{2}{*}{$\begin{array}{l}\text { DOMÍNIO } \\
\text { (peso) }\end{array}$} & \multicolumn{3}{|c|}{ DIMENSÕES } & \multirow{2}{*}{ TEMA (peso) } & \multirow{2}{*}{ INDICADOR } & \multirow{2}{*}{ PESO } & \multirow{2}{*}{ SCORE } \\
\hline & $\mathbf{s}$ & $\mathrm{E}$ & A & & & & \\
\hline \multirow{18}{*}{ 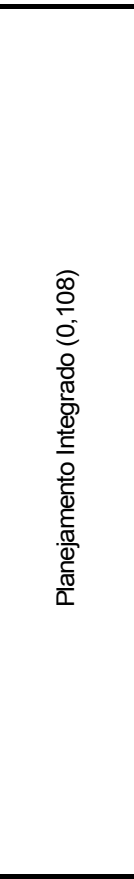 } & & 0,37 & 0,32 & \multirow{2}{*}{$\frac{\text { Capacitação de gestores }}{(0,12)}$} & 7.1.1 Nível de formação de técnicos e gestores & 0,5 & 1 \\
\hline & & & & & 7.1.2 Capacitação de técnicos e gestores & 0,5 & 1 \\
\hline & & 0,30 & 0,35 & $\begin{array}{l}\text { Áreas centrais e de interesse } \\
\text { histórico }(0,11)\end{array}$ & 7.2.1 Vitalidade do centro & 1 & 0,51 \\
\hline & & 0,34 & 0,35 & Integração regional $(0,12)$ & 7.3.1 Consórcios intermunicipais & 1 & 1 \\
\hline & & 0,32 & 0,31 & $\frac{\text { Transparência do processo }}{\text { de planejamento }(0,12)}$ & 7.4.1 Transparência e responsabilidade & 1 & 1 \\
\hline & 0,3 & 0,32 & 0,36 & \multirow{5}{*}{$\begin{array}{l}\text { Planejamento e controle do } \\
\text { uso e ocupação do solo }(0,14)\end{array}$} & 7.5.1 Vazios urbanos & 0,2 & 0,91 \\
\hline & & & & & 7.5.2 Crescimento urbano & 0,2 & 0,94 \\
\hline & & & & & 7.5.3 Densidade populacional urbana & 0,2 & 0 \\
\hline & & & & & 7.5.4 Índice de uso misto & 0,2 & 1 \\
\hline & & & & & 7.5.5 Ocupações irregulares & 0,2 & 1 \\
\hline & & 0,35 & 0,33 & \multirow[t]{2}{*}{$\frac{\text { Planejamento estratégico e }}{\text { integrado }}(0,14)$} & $\begin{array}{l}\text { 7.6.1 Planejamento urbano, ambiental e de } \\
\text { transporte integrado }\end{array}$ & 0,5 & 1 \\
\hline & & & & & 7.6.2 Efetivação e continuidade das ações & 0,5 & 1 \\
\hline & & 0,39 & 0,30 & \multirow{3}{*}{$\begin{array}{l}\text { Planejamento da infraestrutura } \\
\text { urbana e equipamentos } \\
\text { urbanos }(0,13)\end{array}$} & 7.7.1 Parques e áreas verdes & 0,33 & 1 \\
\hline & & & & & 7.7.2 Equipamentos urbanos (escolas) & 0,33 & 1 \\
\hline & & & & & 7.7.3 Equipamentos urbanos (postos de saúde) & 0,33 & 0 \\
\hline & & 0,35 & 0,35 & \multirow{3}{*}{ 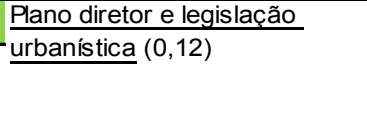 } & 7.8.1 Plano diretor & 0,33 & 1 \\
\hline & & & & & 7.8.2 Legislação urbanística & 0,33 & 1 \\
\hline & & & & & 7.8.3 Cumprimento da legislação urbanística & 0,33 & 1 \\
\hline \multirow{9}{*}{ 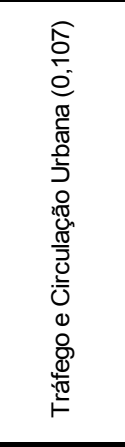 } & & 0,38 & 0,26 & \multirow{3}{*}{ Acidentes de trânsito $(0,21)$} & 8.1.1 Acidentes de trânsito & 0,5 & 0,99 \\
\hline & & & & & 8.1.2 Acidentes com pedestres e ciclistas & 0,5 & 1 \\
\hline & & & & & 8.1.3 Prevenção de acidentes & $-{ }^{*}$ & VAZIO \\
\hline & & 0,31 & 0,30 & $\frac{\text { Educação para o trânsito }}{(0,19)}$ & 8.2.1 Educação para o trânsito & 1 & 1 \\
\hline &, 25 & 0,35 & 0,36 & Fluidez e circulação $(0,19)$ & 8.3.1 Congestionamento & $-{ }^{*}$ & VAZIO \\
\hline & & & & & 8.3.2 Velocidade média do tráfego & 1 & 0,38 \\
\hline & 38 & 0,33 & 0,33 & $\begin{array}{l}\text { Operação e fiscalização de } \\
\text { trânsito }(0,20) \\
\end{array}$ & 8.4.1 Violação das leis de trânsito & 1 & 0,88 \\
\hline & & 0,31 & 0,36 & Transporte individual $(0,21)$ & 8.5.1 Índice de motorização & 0,5 & 0 \\
\hline & & & & & 8.5.2 Taxa de ocupação de veículos & 0,5 & 0,15 \\
\hline \multirow{18}{*}{ 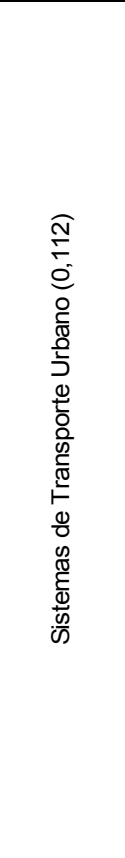 } & & 0,33 & 0,32 & \multirow{8}{*}{$\begin{array}{l}\text { Disponibilidade e qualidade do } \\
\text { transporte público }(0,23)\end{array}$} & 9.1.1 Extensão da rede transporte público & 0,12 & 0,13 \\
\hline & & & & & $\begin{array}{l}\text { 9.1.2 Frequência de atendimento do transporte } \\
\text { público }\end{array}$ & 0,12 & 1 \\
\hline & & & & & 9.1.3 Pontualidade & 0,12 & 0,99 \\
\hline & & & & & 9.1.4 Velocidade média do transporte público & 0,12 & 0,45 \\
\hline & & & & & 9.1.5 Idade média da frota de transporte público & 0,12 & 0,83 \\
\hline & & & & & 9.1.6 Índice de passageiros por quilômetro & 0,12 & 1 \\
\hline & & & & & 9.1.7 Passageiros transportados anualmente & 0,12 & 0,5 \\
\hline & & & & & $\begin{array}{l}\text { 9.1.8 Satisfação do usuário com o serviço de } \\
\text { transporte público }\end{array}$ & 0,12 & 0,59 \\
\hline & 0,3 & 0,34 & 0,34 & \multirow[t]{3}{*}{ Diversificação modal $(0,18)$} & 9.2.1 Diversidade de modos de transporte & 1 & 0,75 \\
\hline & & & & & 9.2.2 Transporte coletivo $x$ transporte individual & $--^{*}$ & VAZIO \\
\hline & & & & & $\begin{array}{l}\text { 9.2.3 Modos não motorizados } x \text { modos } \\
\text { motorizados }\end{array}$ & $-{ }^{*}$ & VAZIO \\
\hline & 32 & 0,35 & 0,31 & \multirow{2}{*}{$\frac{\text { Regulação e fiscalização do }}{\text { transporte público }(0,18)}$} & 9.3.1 Contratos e licitações & 0,5 & 1 \\
\hline & & & & & 9.3.2 Transporte clandestino & 0,5 & 1 \\
\hline & 37 & 0,33 & 0,30 & \multirow{2}{*}{$\begin{array}{l}\text { Integração do transporte } \\
\text { público }(0,22)\end{array}$} & 9.4.1 Terminais intermodais & 0,5 & 0 \\
\hline & & & & & 9.4.2 Integração do transporte público & 0,5 & 1 \\
\hline & & 0,37 & 0,35 & \multirow[t]{3}{*}{ Política tarifária $(0,19)$} & 9.5.1 Descontos e gratuidades & 0,33 & 1 \\
\hline & & & & & 9.5.2 Tarifas de transporte & 0,33 & 0,66 \\
\hline & & & & & 9.5.3 Subsídios públicos & 0,33 & 0,75 \\
\hline
\end{tabular}

*Peso zero pela inexistência de dados, redistribuído para os demais indicadores do mesmo tema.

Fonte: Costa (2008) 
O resultado obtido para os indicadores não é o único a ser considerado para o desempenho do IMUS $_{\text {Global. }}$ Como o índice é composto por um sistema de pesos, a importância de cada indicador varia em relação aos demais. Dessa forma é preciso considerar o peso acumulado dos indicadores, que equivale ao produto de pesos dos domínios, temas e indicadores correspondentes. Assim, indicadores que possuírem maiores pesos acumulados são os que proporcionam as maiores variações no resultado final do índice.

Como exemplo, tem-se o cálculo do peso acumulado do indicador Acessibilidade ao transporte público:

$$
\mathrm{PesO}_{\text {Acumulado }}=\mathrm{PesO}_{\text {Dominoo }} \times \mathrm{PesO}_{\underline{\text { Tema }}} \times \mathrm{PesO}_{\text {Indicador }}
$$

Peso $_{\text {Dominio }}=0,108$

$\mathrm{PesO}_{\underline{\text { Tema }}}=0,290$

Peso $_{\text {Indicador }}=0,330$

Multiplicando-se os pesos tem-se:

$$
\begin{gathered}
\text { Peso }_{\text {Acumulado }}=0,108 \times 0,290 \times 0,330 \\
\text { Peso }_{\text {Acumulado }}=0,0103
\end{gathered}
$$

A realização do cálculo de pesos acumulados para todos os indicadores passíveis de aplicação permite ordenar as questões de maior relevância para o resultado final do índice. Ou seja, indicadores com pesos acumulados mais altos são os que podem provocar as maiores variações no IMUS, tanto para melhor, caso possuam scores elevados, como para pior, caso possuam scores baixos. A Tabela 8 apresenta o resultado do cálculo de pesos acumulados para todos os 87 indicadores que compõem a estrutura do índice, ordenados em escala decrescente por sua importância para Curitiba. 
Tabela 8: Indicadores ordenados por pesos acumulados, em Curitiba

\begin{tabular}{|c|c|c|c|}
\hline DOMÍNIO & ID & INDICADOR & $\begin{array}{c}\text { PESO } \\
\text { ACUMULADO }\end{array}$ \\
\hline INFRAESTRUTURA & 5.2 .1 & Vias para transporte coletivo & 0,0648 \\
\hline MODOS NÃO MOTORIZADOS & 6.3 .4 & Ações para redução do tráfego motorizado & 0,0385 \\
\hline ASPECTOS POLITICOS & 4.3 .1 & Política de mobilidade urbana & 0,0384 \\
\hline \multirow{2}{*}{ ASPECTOS AMBIENTAIS } & 2.1 .3 & População exposta ao ruído de tráfego & 0,0294 \\
\hline & 2.1 .4 & Estudos de Impacto Ambiental & 0,0294 \\
\hline \multirow{2}{*}{ ASPECTOS SOCIAIS } & 3.5 .1 & Qualidade de Vida & 0,0292 \\
\hline & 3.1 .1 & Informação disponível ao cidadão & 0,0281 \\
\hline \multirow{2}{*}{ ASPECTOS AMBIENTAIS } & 2.2 .1 & Consumo de combustível & 0,0271 \\
\hline & 2.2 .2 & Uso de energia limpa e combustíveis alternativos & 0,0271 \\
\hline \multirow{2}{*}{ ASPECTOS SOCIAIS } & 3.4 .1 & Participação na tomada de decisão & 0,0259 \\
\hline & 3.3 .1 & Educação para o desenvolvimento sustentável & 0,0248 \\
\hline \multirow{2}{*}{ ACESSIBILIDADE } & 1.3 .1 & Fragmentação urbana & 0,0238 \\
\hline & 1.4 .1 & Ações para acessibilidade universal & 0,0227 \\
\hline \multirow{3}{*}{ TRÁFEGO E CIRCULAÇÃO URBANA } & 8.4 .1 & Violação das leis de trânsito & 0,0214 \\
\hline & 8.2 .1 & Educação para o trânsito & 0,0203 \\
\hline & 8.3 .2 & Velocidade média de tráfego & 0,0203 \\
\hline $\begin{array}{l}\text { SISTEMAS DE TRANSPORTE } \\
\text { URBANO }\end{array}$ & 9.2 .1 & Diversidade de modos de transporte & 0,0202 \\
\hline \multirow{2}{*}{ ASPECTOS POLITICOS } & 4.1 .1 & Integração entre níveis de governo & 0,0192 \\
\hline & 4.1 .2 & Parcerias público/privadas & 0,0192 \\
\hline \multirow{2}{*}{ MOdOS NÃO MOTORIZADOS } & 6.2 .1 & Vias para pedestres & 0,0187 \\
\hline & 6.2 .2 & Vias com calçadas & 0,0187 \\
\hline \multirow{3}{*}{ INFRAESTRUTURA } & 5.1 .1 & Densidade e conectividade da rede viária & 0,0182 \\
\hline & 5.1 .2 & Vias pavimentadas & 0,0182 \\
\hline & 5.1 .3 & $\begin{array}{l}\text { Despesas com manutenção da infraestrutura de } \\
\text { transportes }\end{array}$ & 0,0182 \\
\hline \multirow{2}{*}{ PLANEJAMENTO INTEGRADO } & 7.3 .1 & Consórcios intermunicipais & 0,0130 \\
\hline & 7.4 .1 & Transparência e responsabilidade & 0,0130 \\
\hline \multirow{2}{*}{$\begin{array}{l}\text { SISTEMAS DE TRANSPORTE } \\
\text { URBANO }\end{array}$} & 9.4 .1 & Terminais intermodais & 0,0123 \\
\hline & 9.4 .2 & Integração do transporte público & 0,0123 \\
\hline PLANEJAMENTO INTEGRADO & 7.2 .1 & Vitalidade do centro & 0,0119 \\
\hline \multirow{3}{*}{ MODOS NÃO MOTORIZADOS } & 6.1 .1 & Extensão e conectividade de ciclovias & 0,0113 \\
\hline & 6.1 .2 & Frota de bicicletas & 0,0113 \\
\hline & 6.1 .3 & Estacionamento para bicicletas & 0,0113 \\
\hline \multirow{4}{*}{ TRÁFEGO E CIRCULAÇÃo URBANA } & 8.1 .1 & Acidentes de trânsito & 0,0112 \\
\hline & 8.1 .2 & Acidentes com pedestres e ciclistas & 0,0112 \\
\hline & 8.5 .1 & Índice de motorização & 0,0112 \\
\hline & 8.5 .2 & Taxa de ocupação dos veículos & 0,0112 \\
\hline \multirow{3}{*}{ ACESSIBILIDADE } & 1.1 .1 & Acessibilidade ao transporte público & 0,0103 \\
\hline & 1.1 .2 & $\begin{array}{l}\text { Transporte público para pessoas com necessidades } \\
\text { especiais }\end{array}$ & 0,0103 \\
\hline & 1.1 .3 & Despesas com transporte & 0,0103 \\
\hline \multirow{2}{*}{$\begin{array}{l}\text { SISTEMAS DE TRANSPORTE } \\
\text { URBANO }\end{array}$} & 9.3 .1 & Contratos e licitações & 0,0101 \\
\hline & 9.3 .2 & Transporte clandestino & 0,0101 \\
\hline
\end{tabular}


Tabela 8: (continuação) Indicadores ordenados por pesos acumulados, em Curitiba

\begin{tabular}{|c|c|c|c|}
\hline DOMÍNIO & ID & INDICADOR & $\begin{array}{l}\text { PESO } \\
\text { ACUMULADO }\end{array}$ \\
\hline \multirow{4}{*}{ ASPECTOS POLÍTICOS } & 4.2 .1 & Captação de recursos & 0,0093 \\
\hline & 4.2 .2 & Investimentos em sistemas de transportes & 0,0093 \\
\hline & 4.2 .3 & Distribuição dos recursos (público x privado) & 0,0093 \\
\hline & 4.2 .4 & Distribuição dos recursos (motorizados x não motorizados) & 0,0093 \\
\hline \multirow{4}{*}{ ACESSIBILIDADE } & 1.2 .1 & $\begin{array}{l}\text { Travessias adaptadas a pessoas com necessidades } \\
\text { especiais }\end{array}$ & 0,0076 \\
\hline & 1.2 .2 & Acessibilidade a espaços abertos & 0,0076 \\
\hline & 1.2 .3 & $\begin{array}{l}\text { Vagas de estacionamento para pessoas com } \\
\text { necessidades especiais }\end{array}$ & 0,0076 \\
\hline & 1.2 .5 & Acessibilidade aos serviços essenciais & 0,0076 \\
\hline \multirow{2}{*}{ PLANEJAMENTO INTEGRADO } & 7.6.1 & $\begin{array}{l}\text { Planejamento urbano, ambiental e de transportes } \\
\text { integrado }\end{array}$ & 0,0076 \\
\hline & 7.6 .2 & Efetivação e continuidade das ações & 0,0076 \\
\hline \multirow{3}{*}{$\begin{array}{l}\text { SISTEMAS DE TRANSPORTE } \\
\text { URBANO }\end{array}$} & 9.5 .1 & Descontos e gratuidades & 0,0070 \\
\hline & 9.5 .2 & Tarifas de transportes & 0,0070 \\
\hline & 9.5 .3 & Subsídios públicos & 0,0070 \\
\hline \multirow{8}{*}{ PLANEJAMENTO INTEGRADO } & 7.1 .1 & Nível de formação de técnicos e gestores & 0,0065 \\
\hline & 7.1 .2 & Capacitação de técnicos e gestores & 0,0065 \\
\hline & 7.7 .1 & Parques e áreas verdes & 0,0046 \\
\hline & 7.7 .2 & Equipamentos urbanos (escolas) & 0,0046 \\
\hline & 7.7 .3 & Equipamentos urbanos (postos de saúde) & 0,0046 \\
\hline & 7.8 .1 & Plano Diretor & 0,0043 \\
\hline & 7.8 .2 & Legislação urbanística & 0,0043 \\
\hline & 7.8 .3 & Cumprimento da legislação urbanística & 0,0043 \\
\hline \multirow{8}{*}{$\begin{array}{l}\text { SISTEMAS DE TRANSPORTE } \\
\text { URBANO }\end{array}$} & 9.1 .1 & Extensão da rede de transporte público & 0,0031 \\
\hline & 9.1 .2 & Frequência de atendimento do transporte público & 0,0031 \\
\hline & 9.1 .3 & Pontualidade & 0,0031 \\
\hline & 9.1 .4 & Velocidade média do transporte público & 0,0031 \\
\hline & 9.1 .5 & Idade média da frota de transporte público & 0,0031 \\
\hline & 9.1 .6 & Índice de passageiros por quilômetro & 0,0031 \\
\hline & 9.1 .7 & Passageiros transportados anualmente & 0,0031 \\
\hline & 9.1 .8 & Satisfação do usuário com o serviço de transporte público & 0,0031 \\
\hline \multirow{5}{*}{ PLANEJAMENTO INTEGRADO } & 7.5 .1 & Vazios urbanos & 0,0030 \\
\hline & 7.5 .2 & Crescimento urbano & 0,0030 \\
\hline & 7.5 .3 & Densidade populacional urbana & 0,0030 \\
\hline & 7.5 .4 & Índice de uso misto & 0,0030 \\
\hline & 7.5 .5 & Ocupações irregulares & 0,0030 \\
\hline ACESSIBILIDADE & 1.2 .4 & Acessibilidade a edifícios públicos & $0,0000^{*}$ \\
\hline \multirow{2}{*}{ ASPECTOS AMBIENTAIS } & 2.1 .1 & Emissões de CO & $0,0000^{*}$ \\
\hline & 2.1 .2 & Emissões de $\mathrm{CO}_{2}$ & $0,0000^{*}$ \\
\hline ASPECTOS SOCIAIS & 3.2 .1 & Equidade vertical (renda) & $0,0000^{*}$ \\
\hline INFRAESTRUTURA & 5.1 .4 & Sinalização viária & $0,0000^{*}$ \\
\hline \multirow{3}{*}{ MODOS NÃO MOTORIZADOS } & 6.3 .1 & Distância de viagem & $0,0000^{*}$ \\
\hline & 6.3 .2 & Tempo de viagem & $0,0000^{*}$ \\
\hline & 6.3 .3 & Número de viagens & $0,0000^{*}$ \\
\hline \multirow{2}{*}{ TRÁFEGO E CIRCULAÇÃo URBANA } & 8.1 .3 & Prevenção de acidentes & $0,0000^{*}$ \\
\hline & 8.3 .1 & Congestionamento & $0,0000^{*}$ \\
\hline \multirow{2}{*}{$\begin{array}{l}\text { SISTEMAS DE TRANSPORTE } \\
\text { URBANO }\end{array}$} & 9.2 .2 & Transporte coletivo $x$ transporte individual & $0,0000^{*}$ \\
\hline & 9.2 .3 & Modos não motorizados $x$ modos motorizados & $0,0000^{*}$ \\
\hline
\end{tabular}

*Indicadores com score VAZIO pela inexistência de dados para o cálculo do IMUS. 
A identificação dos indicadores que proporcionam maior interferência no índice é importante para o gestor municipal, pois os resultados apresentados pelo cálculo do IMUS podem identificar políticas públicas para intervenções de impacto sobre a mobilidade urbana sustentável. Isso significa que os primeiros indicadores da lista são necessariamente prioritários em ação, caso se deseje atingir um índice global maior.

É aconselhável lembrar que os indicadores considerados vazios tiveram seus pesos redistribuídos, dessa forma encontram-se no final da lista de importância. Caso algum deles se torne passível de cálculo, deverá obrigatoriamente ser inserido com os demais, de acordo com seus pesos respectivos.

Outro fator a ser considerado para a análise de desempenho do índice é o efetivo score obtido para cada indicador calculado. Obviamente valores altos correspondem a situações favoráveis e valores baixos indicam deficiências. No entanto, esses valores isolados apenas qualificam os indicadores. Uma análise mais profunda do desempenho da mobilidade associada a uma perspectiva de intervenção sobre as deficiências necessariamente exige uma combinação de informações. Nesse caso os dados analisados em conjunto são os pesos acumulados dos indicadores e seus scores.

É importante considerar que indicadores que possuírem pesos acumulados elevados e scores igualmente altos são muito favoráveis para o resultado final. Mas indicadores com pesos acumulados baixos e scores também baixos, apesar do desempenho ruim, não interferem tão negativamente. Da mesma forma que indicadores com pesos acumulados baixos e scores altos, que apesar de representarem uma condição favorável, não interferem tão positivamente no resultado do índice. Porém, indicadores com pesos acumulados elevados e scores de baixo desempenho são um problema para o IMUS avaliado.

A Tabela 9 mostra a comparação entre os dois itens mencionados, pesos acumulados e scores dos indicadores calculados para o IMUS de Curitiba. Para a classificação dos pesos acumulados a cor verde corresponde aos valores superiores a 0,02. A cor amarela indica valores correspondentes ao intervalo entre 0,01 e 0,02, assim como a cor vermelha equivale a valores inferiores a 0,01 . As cores utilizadas para representar os scores (verde, amarelo e vermelho) indicam o desempenho de cada termo, conforme categoria apresentada na Figura 20. 
Comparando-se as cores das colunas é possível verificar que 13 indicadores correspondem de forma favorável ao bom desempenho do índice, apresentando a cor verde em ambos os elementos. São eles:

- Ações para acessibilidade universal (ACESSIBILIDADE);

- População exposta ao ruído de tráfego (ASPECtos AmBIENTAIS);

- Estudos de impacto ambiental (ASPECTOS AmBIENTAIS);

- Consumo de combustível (ASPECTOS AmBIENTAIS);

- Informação disponível ao cidadão (ASPECTOS SociaIS);

- Educação para o desenvolvimento sustentável (ASPECTOS SoCIAIS);

- Participação na tomada de decisão (ASPECTOS SociAIS);

- Qualidade de vida (ASPECTOS SOcIAIS);

- Política de mobilidade urbana (AsPeCtos Políticos);

- Vias para transporte coletivo (INFRAESTRUTURA);

- Educação para o trânsito (TRÁfEgo e CIRCulação URBANA);

- Violação das leis de trânsito (TRÁFEgo e CiRCulação URBANA);

- Diversidade dos modos de transporte (SISTEMAS DE TRANSPORTE URBANO).

Não integra o grupo nenhum indicador do domínio MODOS NÃO MOTORIZADOS ou PLANEJAMENTO INTEGRADO.

Os indicadores que obtiveram scores baixos, apesar de possuírem pesos acumulados elevados, são apenas quatro:

- Fragmentação urbana (ACESSIBILIDADE);

- Uso de energia limpa e combustíveis alternativos (ASPECTOS AMBIENTAIS);

- Ações para a redução do tráfego motorizado (MOdOs NÃo MOTORIZADOS);

- Velocidade média do tráfego (TRÁFEgo e CIRCULAÇÃo URBANA).

Esses indicadores podem sugerir pontos de atuação bastante diretos para gestores que desejem aumentar o desempenho do índice. Caso seus scores atingissem o máximo $(1,00)$ o resultado do IMUS $_{\text {global }}$ chegaria a 0,837 , que representa uma grande evolução considerando apenas quatro indicadores. No entanto, nem sempre as soluções são possíveis. 
Tabela 9: Comparação entre pesos acumulados e scores dos indicadores

\begin{tabular}{|c|c|c|c|c|c|c|c|c|}
\hline \multirow{2}{*}{$\begin{array}{l}\text { DOMíNIO } \\
\text { (peso) }\end{array}$} & \multicolumn{3}{|c|}{ DIMENSÕES } & \multirow{2}{*}{ TEMAS (peso) } & \multirow{2}{*}{ INDICADORES } & \multirow{2}{*}{ PESO } & \multirow{2}{*}{$\begin{array}{l}\text { PESO } \\
\text { ACUM. }\end{array}$} & \multirow{2}{*}{ SCORE } \\
\hline & $\mathrm{s}$ & $\mathrm{E}$ & A & & & & & \\
\hline \multirow{10}{*}{ 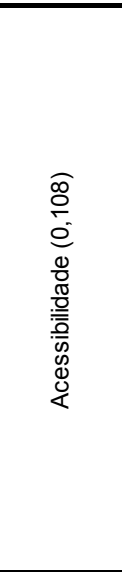 } & & 0,36 & 0,26 & Acessibilidade aos sistemas & 1.1.1 Acessibilidade ao transporte público & 0,33 & 0,0103 & 0,95 \\
\hline & & & & & $\begin{array}{l}\text { Transporte público para pessoas com } \\
\text { necessidades especiais }\end{array}$ & 0,33 & 0,0103 & 1 \\
\hline & & & & & 1.1.3 Despesas com transportes & 0,33 & 0,0103 & 0,82 \\
\hline & & 0,32 & 0,27 & $\frac{\text { Acessibilidade universal }}{(0,28)}$ & $\begin{array}{l}\text { 1.2.1 Travessias adaptadas para pessoas com } \\
\text { necessidades especiais }\end{array}$ & 0,25 & 0,0076 & 0,6 \\
\hline & & & & & 1.2.2 Acessibilidade aos espaços abertos & 0,25 & 0,0076 & 0,82 \\
\hline & & & & & $\begin{array}{l}\text { 1.2.3 Vagas de estacionamento para pessoas } \\
\text { com necessidades especiais }\end{array}$ & 0,25 & 0,0076 & 0,2 \\
\hline & & & & & 1.2.4 Acessibilidade a edifícios públicos & $-{ }^{*}$ & 0 & VAZIO \\
\hline & & & & & 1.2.5 Acessibilidade aos serviços essenciais & 0,25 & 0,0076 & 0,85 \\
\hline & & 0,30 & 0,32 & Barreiras físicas $(0,22)$ & 1.3.1 Fragmentação urbana & 1 & 0,0238 & 0 \\
\hline & & 0,28 & 0,27 & $\begin{array}{l}\text { Legislação para pessoas com } \\
\text { necessidades especiais } \\
(0,21)\end{array}$ & 1.4.1 Ações para acessibilidade universal & 1 & 0,0227 & 1 \\
\hline \multirow{6}{*}{ 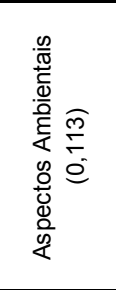 } & & 0,28 & 0,43 & Controle dos impactos no meio & 2.1.1 Emissões de CO & $-{ }^{*}$ & 0 & VAZIO \\
\hline & & & & ambiente $(0,52)$ & 2.1.2 Emissões de $\mathrm{CO}_{2}$ & $-{ }^{*}$ & 0 & VAZIO \\
\hline & & & & & 2.1.3 População exposta ao ruído de tráfego & 0,5 & 0,0294 & 0,96 \\
\hline & & & & & 2.1.4 Estudos de impacto ambiental & 0,5 & 0,0294 & 1 \\
\hline & & 0,32 & 0,42 & Recursos naturais $(0,48)$ & 2.2.1 Consumo de combustível & 0,5 & 0,0271 & 0,99 \\
\hline & & & & & $\begin{array}{l}\text { 2.2.2 Uso de energia limpa e combustiveis } \\
\text { alternativos }\end{array}$ & 0,5 & 0,0271 & 0,35 \\
\hline \multirow{5}{*}{ 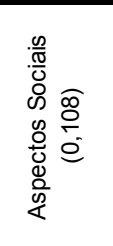 } & & 0,31 & 0,29 & Apoio ao cidadão $(0,26)$ & 3.1.1 Informação disponível ao cidadão & 1 & 0,0281 & 1 \\
\hline & & 0,30 & 0,25 & Inclusão social $(0,00)$ & 3.2.1 Equidade vertical (renda) & $-{ }^{*}$ & 0 & VAZIO \\
\hline & & 0,30 & 0,31 & Educação e cidadania 0,23 ) & $\begin{array}{l}\text { Educação para o desenvolvimento } \\
\text { sustentável }\end{array}$ & 1 & 0,0248 & 0,75 \\
\hline & & 0,27 & 0,32 & Participação popular $(0,24)$ & 3.4.1 Participação na tomada de decisão & 1 & 0,0259 & 1 \\
\hline & & 0,30 & 0,35 & Qualidade de vida $(0,27)$ & 3.5.1 Qualidade de vida & 1 & 0,0292 & 0,8 \\
\hline \multirow{7}{*}{ 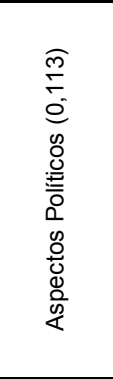 } & & 0,34 & 0,32 & Integração de ações políticas & 4.1.1 Integração entre níveis de governo & 0,5 & 0,0192 & 0,75 \\
\hline & & & & $(0,34)$ & 4.1.2 Parcerias público-privadas & 0,5 & 0,0192 & 1 \\
\hline & & 0,40 & 0,27 & Captação e gerenciamento de & 4.2.1 Captação de recursos & 0,25 & 0,0093 & 0,31 \\
\hline & & & & recursos $(0,33)$ & 4.2.2 Investimentos em sistemas de transporte & 0,25 & 0,0093 & 1 \\
\hline & & & & & $\begin{array}{l}\text { 4.2.3 Distribuição dos recursos (coletivo } x \\
\text { privado) }\end{array}$ & 0,25 & 0,0093 & 0,25 \\
\hline & & & & & $\begin{array}{l}\text { 4.2.4 } \begin{array}{l}\text { Distribuição dos recursos (motorizados } x \\
\text { não motorizados) }\end{array}\end{array}$ & 0,25 & 0,0093 & 0,25 \\
\hline & & 0,33 & 0,32 & $\begin{array}{l}\text { Politica de mobilidade urbana } \\
(0,34)\end{array}$ & 4.3.1 Política de mobilidade urbana & 1 & 0,0384 & 1 \\
\hline \multirow{5}{*}{ 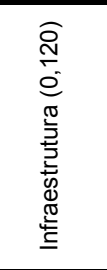 } & & 0,41 & 0,31 & Provisão e manutenção da & 5.1.1 Densidade e conectividade da rede viária & 0,33 & 0,0182 & 1 \\
\hline & & & & infraestrutura de transportes & 5.1.2 Vias pavimentadas & 0,33 & 0,0182 & 0,89 \\
\hline & & & & & $\begin{array}{l}\text { 5.1.3 Despesas com manutenção da } \\
\text { infraestrutura }\end{array}$ & 0,33 & 0,0182 & 1 \\
\hline & & & & & 5.1.4 Sinalização viária & $-{ }^{*}$ & 0 & VAZIO \\
\hline & & 0,35 & 0,33 & $\begin{array}{l}\text { Distribuição da infraestrutura } \\
\text { de transporte }(0,54)\end{array}$ & 5.2.1 Vias para transporte coletivo & 1 & 0,0648 & 0,9 \\
\hline \multirow{9}{*}{ 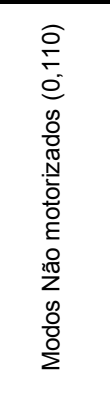 } & & 0,29 & 0,39 & Transporte cicloviário $(0,31)$ & 6.1.1 Extensão e conectividade de ciclovias & 0,33 & 0,0113 & 0,25 \\
\hline & & & & & 6.1.2 Frotas de bicicletas & 0,33 & 0,0113 & 1 \\
\hline & & & & & 6.1.3 Estacionamento de bicicletas & 0,33 & 0,0113 & 0 \\
\hline & & 0,28 & 0,39 & Modos não motorizados $(0,34)$ & 6.2.1 Vias para pedestres & 0,5 & 0,0187 & 0,25 \\
\hline & & & & & 6.2.2 Vias com calçadas & 0,5 & 0,0187 & 1 \\
\hline & & 0,32 & 0,40 & Redução de viagens $(0,35)$ & 6.3.1 Distância de viagem & $--^{*}$ & 0 & VAZIO \\
\hline & & & & & 6.3.2 Tempo de viagem & $-*$ & 0 & VAZIO \\
\hline & & & & & 6.3.3 Número de viagens & $-{ }^{*}$ & 0 & VAZIO \\
\hline & & & & & 6.3.4 Ações para redução do tráfego motorizado & 1 & 0,0385 & 0,25 \\
\hline
\end{tabular}

*Peso zero pela inexistência de dados, redistribuído para os demais indicadores do mesmo tema.

Fonte: Adaptado de Costa (2008) 
Tabela 9: (continuação) Comparação entre pesos acumulados e scores dos indicadores

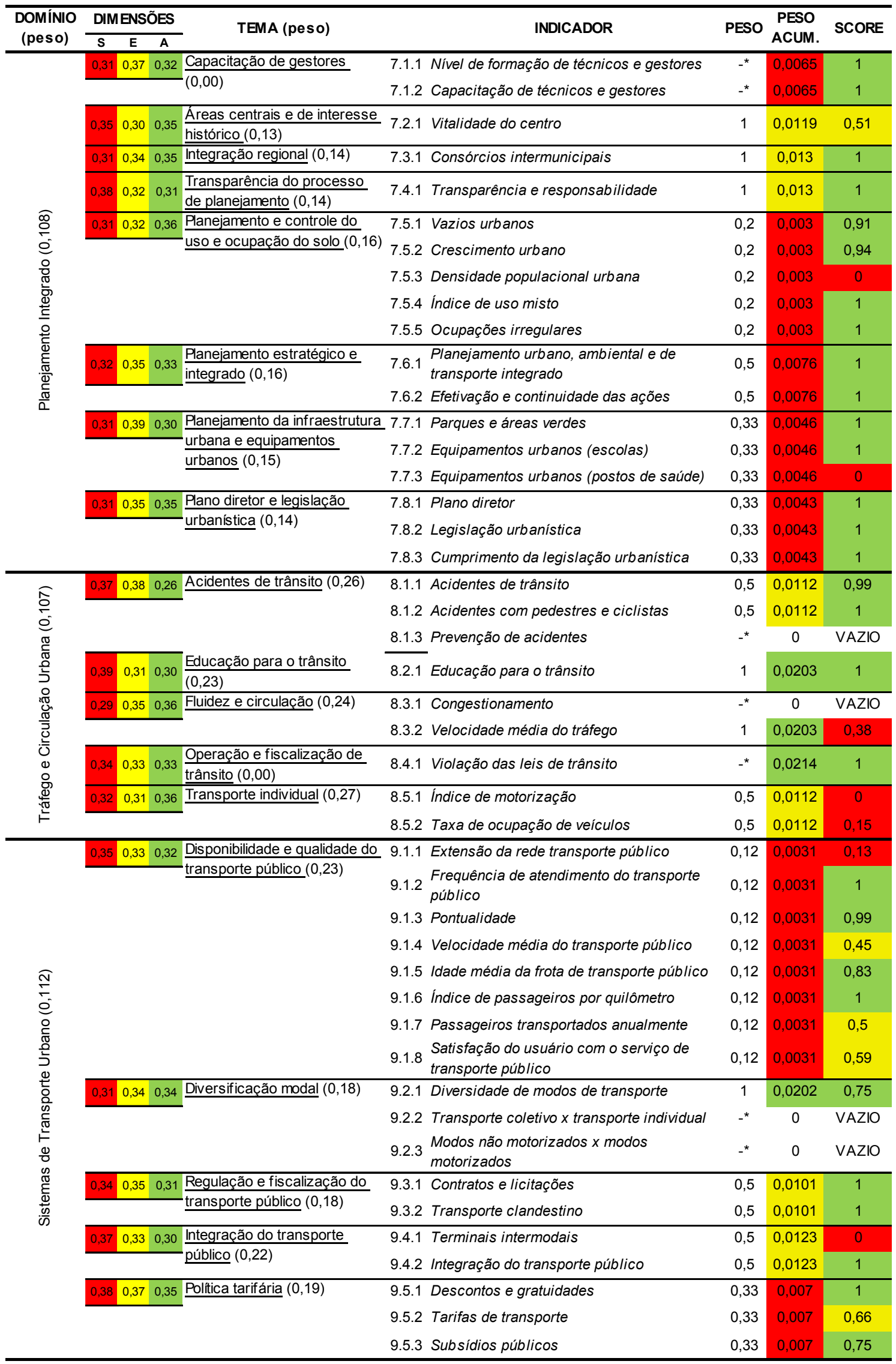

*Peso zero pela inexistência de dados, redistribuído para os demais indicadores do mesmo tema.

Fonte: Costa (2008) 


\subsubsection{Indicadores de alto desempenho}

A aplicação do método possibilitou a identificação de muitos fatores positivos para a cidade de Curitiba, fato observado com os $45 \%$ de indicadores que obtiveram score máximo. As maiores qualidades da cidade de Curitiba quanto à mobilidade sustentável encontram-se na adoção de medidas administrativas significativas, existência e cumprimento de leis específicas, políticas sociais e investimentos na infraestrutura urbana.

Certamente um dos destaques esperados para a cidade refere-se à existência e ao cumprimento de leis que favorecem a mobilidade sustentável, como o Plano Diretor e a Política de Mobilidade Urbana.

O famoso sistema de transporte público da cidade apresenta características muito positivas, como seu amplo atendimento a portadores de necessidades especiais, alta frequência e ampla integração. A inexistência de transporte clandestino, bastante comum nas grandes cidades brasileiras, também é reflexo da qualidade desse sistema.

Questões sociais obtiveram destaque, favorecendo o resultado do índice. A comunidade participa do processo de tomada de decisões, assim como possui canais diretos de informação, além de ser alvo de campanhas de educação para o trânsito.

Ainda a infraestrutura urbana representou um papel importante para o IMUS em Curitiba. A cidade demonstrou investir recursos na manutenção das vias, bem como calçadas e equipamentos públicos, mas principalmente no sistema de transporte público, seu grande destaque positivo.

Os grupos de indicadores citados refletem o bom desempenho dos domínios, apresentado no item 5.3 desse capítulo. Os que obtiveram scores mais favoráveis foram sem dúvida INFRAESTRUTURA, ASPECTOS SOCIAIS E PLANEJAMENTO INTEGRADO, ou seja, são os domínios que melhor refletem os indicadores apresentados. 


\subsubsection{Indicadores de baixo desempenho}

O IMUS pode ser uma importante ferramenta de planejamento para os municípios, pois além de proporcionar uma detalhada análise das condições de mobilidade, ainda permite identificar pontos de atuação para sua melhora. Os indicadores que obtiverem os menores scores são sem dúvida as maiores deficiências e necessitam de intervenção, sendo considerados os problemas da mobilidade na cidade.

Como foi apresentado na Tabela 9, quatro indicadores com pesos acumulados elevados obtiveram desempenhos baixos para seus scores (Fragmentação urbana, Ações para a redução do tráfego motorizado e Velocidade média do tráfego). No entanto, apenas o primeiro desses obteve resultado zero, o pior resultado esperado para um indicador.

Outros indicadores também obtiveram o mesmo score, mas não foram citados em um primeiro momento por possuírem pesos acumulados menores. Porém, seus resultados são significativos para o IMUS e também para a cidade, pois demonstram deficiências quanto a mobilidade sustentável. Assim, eles serão considerados como parte integrante da problemática local.

Dessa forma, os indicadores considerados de baixo desempenho, refletido em um score zero, foram: Fragmentação urbana, Estacionamento de bicicletas, Densidade populacional urbana, Equipamentos urbanos (postos de saúde), Índice de motorização e Terminais intermodais. Eles refletem problemas muito específicos da cidade de Curitiba, como as altas taxas de motorização da população e o uso de um sistema de transporte público baseado apenas em um único modo. Ocorre ainda na cidade a pouca valorização dos modos não motorizados, além da existência de um planejamento de uso e ocupação do solo que condicionou diferentes densidades populacionais pelo território.

Fragmentação urbana e Densidade populacional urbana são indicadores de baixo desempenho, mas que envolvem situações diferenciadas para a cidade ou para o índice, como problemas na sua metodologia de cálculo e, portanto serão tratados mais adiante. Por outro lado, Estacionamento de bicicletas, Índice de motorização e Terminais intermodais possuem um ponto em comum: a dependência da população sobre os modos motorizados, especialmente o automóvel. 
Curitiba é hoje a capital brasileira com maior índice de motorização, atingindo 614 veículos/1000 habitantes, segundo dados do DENATRAN (2008). Além disso, não há incentivos para o uso da bicicleta como modo efetivo de transporte, sendo essa considerada sobretudo como uma forma de lazer. Isso se reflete no desenho das ciclovias urbanas que se preocupam em unir parques e áreas verdes. Como não é usada como modo de transporte regular, a bicicleta perdeu espaço até mesmo nos terminais de ônibus, que não oferecem áreas destinadas para estacionamento e guarda.

O baixo desempenho dos indicadores apresentados reflete um problema social muito maior: a cultura do automóvel. Mesmo uma cidade como Curitiba, que possui um sistema de transporte público eficiente, enfrenta as dificuldades provocadas pela escolha equivocada da população de utilizar o transporte motorizado individual para realizar suas viagens diárias.

\subsection{Análise Intraurbana}

A avaliação de desempenho do IMUS revela o panorama da mobilidade sustentável no município avaliado, mas sabe-se que as cidades possuem diferenças quanto à oferta de seus serviços e infraestrutura em seu território. Pode-se esperar que uma cidade com bom desempenho no índice em questão mostre certa uniformidade em suas qualidades por toda a área urbana, sem privilegiar setores ou camadas específicas da população. Isso significa que o cálculo deva ser realizado não apenas no município como um todo, mas também em subáreas. Tal divisão pode ser definida por bairros, setores censitários do IBGE, ou qualquer outro nível de agregação, contanto que as informações necessárias para sua aplicação estejam disponíveis. Em Curitiba utilizouse uma divisão já estabelecida administrativamente: as Regionais.

Somando um total de nove, cada Regional é composta por um grupo de bairros, cujo número pode variar de uma para outra. Esses foram distribuídos conforme características comuns, além da localização geográfica (ver Figura 21). 


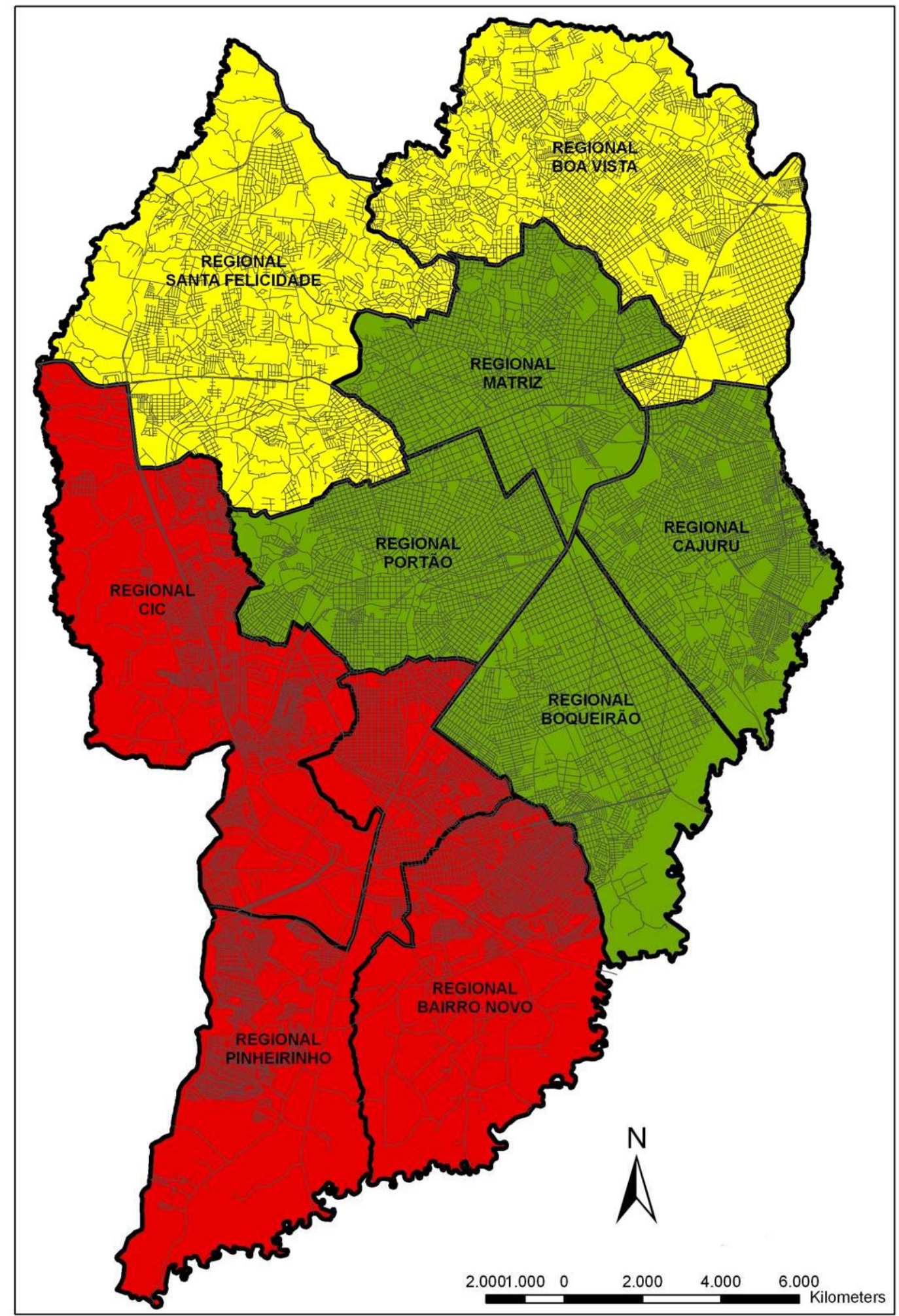

Figura 21: Distribuição das Regionais em Curitiba

Fonte: Adaptado de IPPUC (2009)

Essa é uma divisão estabelecida pela própria administração do município, porém verifica-se que mesmo assim não existem informações desagregadas das mesmas. Isso significa que muitos dados necessários à aplicação do IMUS não são 
disponibilizados conforme tal divisão, sendo apenas encontrados com valores que representam o município como um todo. Apesar de tal limitação, 19 indicadores do total de 87 puderam ser calculados (ver Tabela 10). Esses se referem a dados de origem espacial extraídos de informações gráficas e, portanto, podem ser associados a locais específicos da cidade, como bairros ou regiões distintas.

Tabela 10: Indicadores utilizados para o cálculo do IMUS regional

\begin{tabular}{ll}
\hline \multicolumn{1}{c}{ DOMÍNIOS } & \multicolumn{1}{c}{ INDICADORES } \\
\hline ACESSIBILIDADE & Acessibililidade ao transporte público \\
& Acessibilidade aos serviços essenciais \\
& Fragmentação urbana \\
\hline ASPECTOS AMBIENTAIS & População exposta aos ruídos de tráfego \\
\hline \multirow{3}{*}{ INFRAESTRUTURA } & Densidade e conectividade da rede viária \\
& Vias pavimentadas \\
& Vias para transporte coletivo \\
\hline \multirow{2}{*}{ MODOS NÃO MOTORIZADOS } & Extensão e conectividade de ciclovias \\
& Vias para pedestres \\
\hline PLANEJAMENTO INTEGRADO & Vazios urbanos \\
& Crescimento urbano \\
& Densidade populacional urbana \\
& Índice de uso misto \\
& Ocupações irregulares \\
\hline SISTEMAS DE TRANSPORTE URBANO & Parques e áreas verdes \\
\hline & Equipamentos urbanos (escolas) \\
& Equipamentos urbanos (unidades de saúde) \\
\hline
\end{tabular}

Para as avaliações regionais, nem todos os domínios foram considerados por conta das limitações de indicadores disponíveis. Ficaram de fora ASPECTOS SOCIAIS, Aspectos políticos e TRÁfego e Circulação URbana. Nessas três situações os mesmos representam inteiramente os valores para a cidade de Curitiba, sem receber qualquer interferência de valores específicos da região avaliada. Isso também vale para os 68 indicadores não considerados no cálculo regional, que mantiveram os valores obtidos no cálculo do índice municipal. Os resultados obtidos nos cálculos dos nove índices regionais são apresentados na Tabela 11. 
Tabela 11: Resultados para os cálculos Regionais em Curitiba

\begin{tabular}{lcccc}
\hline \multicolumn{1}{c}{ REGIONAL } & IMUS $_{\text {Global }}$ & IMUS $_{\text {Social }}$ & IMUS $_{\text {Econômica }}$ & IMUS $_{\text {Ambiental }}$ \\
\hline Matriz & 0,772 & 0,262 & 0,256 & 0,255 \\
\hline Portão & 0,757 & 0,256 & 0,251 & 0,249 \\
\hline Boqueirão & 0,754 & 0,255 & 0,250 & 0,248 \\
\hline Cajuru & 0,752 & 0,255 & 0,250 & 0,248 \\
\hline Boa Vista & 0,742 & 0,252 & 0,246 & 0,244 \\
\hline Santa Felicidade & 0,740 & 0,251 & 0,245 & 0,244 \\
\hline CIC & 0,735 & 0,249 & 0,243 & 0,242 \\
\hline Bairro Novo & 0,734 & 0,250 & 0,242 & 0,242 \\
\hline Pinheirinho & 0,733 & 0,249 & 0,242 & 0,242 \\
\hline
\end{tabular}

A Regional mais bem colocada foi a Matriz, que agrega o bairro Centro bem como outros que, por sua localização e importância econômica, são bem servidos de infraestrutura urbana. As duas Regionais que obtiveram resultados mais baixos foram Pinheirinho e Bairro Novo, duas áreas novas na cidade, que apresentam crescimento recente e menor disponibilidade de serviços.

A Figura 21 indica os resultados dos cálculos regionais pela classificação de cores, sendo que os mais altos receberam a cor verde, os intermediários a cor amarela e os mais baixos a cor vermelha. As regionais com melhores desempenhos no cálculo do IMUS (Matriz, Portão, Boqueirão e Cajuru), representadas pela cor verde, apresentam malhas viárias mais compactas, sem apresentar muitos vazios entre essas. Isso indica uma melhor qualidade das conexões viárias, favorecendo o deslocamento em todos os modos de transporte, mas principalmente o modo a pé. Regionais como Santa Felicidade e Boa Vista, representadas pela cor amarela, possuem características distintas, pois agregam uma grande quantidade de parques e áreas verdes, além de atraírem a implantação de condomínios fechados. Essas características são desfavoráveis para a mobilidade, pois podem se tornar barreiras para o deslocamento de pessoas. A Regional CIC, representada pela cor vermelha assim como a Regional Bairro Novo e Pinheirinho, além de ser fragmentada por rodovias também abriga o parque industrial da cidade. Essa condição não a favorece quanto à mobilidade sustentável, uma vez que seu parcelamento diferenciado do solo urbano cria glebas incompatíveis com a escala do pedestre, que realiza seus deslocamentos a pé.

Apesar das diferenças entre Regionais, os resultados obtidos nos cálculos mostraram pequenas variações, o menor de 0,733 e o maior de 0,772. Sem dúvida isso pode ser reflexo da pequena quantidade de indicadores efetivamente utilizados (19 do total de 87), o que pode ter mantido um equilíbrio nos valores. Mas também é possível concluir 
que os valores aproximados representam um padrão de mobilidade urbana sustentável em todas as Regionais da cidade. Isso se deve exatamente a uniformidade dos resultados obtidos, uma vez que considerando apenas os 18 indicadores utilizados a variação do IMUS nas situações extremas (todos iguais a zero ou todos iguais a 1,00 ) seria de 0,588 a 0,816 .

De qualquer forma é possível perceber que as distintas Regionais de Curitiba apresentam características semelhantes quanto à mobilidade sustentável. Esse fato é bastante positivo, pois demonstra que as diferenças econômicas e sociais visíveis no espaço urbano não interferem na uniformidade da mobilidade urbana.

\subsection{Indicadores desfavorecidos pelo método}

A aplicação de alguns indicadores levantou dúvidas quanto à forma de avaliação em que os dados foram submetidos. Determinados indicadores que se referiam a pontos positivos para a cidade obtiveram scores ruins, desfavorecendo assim Curitiba. Esses indicadores são: Densidade populacional urbana e Terminais intermodais.

O score do indicador Densidade populacional urbana foi zero, o que indica que a cidade possui uma densidade média abaixo do considerado aceitável pelo método. Para a mobilidade, densidades altas correspondem a um maior volume de pessoas atendidas pela infraestrutura de transporte em uma área de abrangência menor, o que garante certa economia de recursos públicos, ou também viagens mais curtas que reduzem os tempos de deslocamento. Mas cabe a cada cidade decidir como irá gerir seu parcelamento urbano e uso do solo, definindo suas possibilidades de densificação do espaço. Nem sempre são priorizadas questões referentes à facilidade de deslocamento ou economia de infraestrutura.

Curitiba planejou sua ocupação de forma bastante específica, sendo que seu zoneamento contempla áreas de densidades demográficas bastante distintas. O uso do solo (considerando a possibilidade de verticalização) foi associado à oferta de transporte, sendo esse público, com os corredores de ônibus, ou privado, com as avenidas de tráfego rápido e alta capacidade. À medida que a oferta de transporte é reduzida, a possibilidade de verticalização também cai, resultando num perfil 
escalonado ao longo dessas vias. Nas áreas remanescentes verifica-se uma ocupação de densidade mais reduzida, com edificações mais baixas, sendo que em algumas dessas áreas da cidade propagam-se também condomínios fechados, além de parques e áreas verdes.

Essa característica desfavoreceu a cidade quanto ao cálculo do indicador. Se por um lado tais variações correspondem a uma organização do espaço urbano, ordenando os usos e agregando qualidade de vida à população, por outro elas proporcionam uma densidade populacional média abaixo do esperado. Isso pode ser facilmente compreendido analisando as densidades populacionais verificadas nas Regionais que compõem a cidade (ver Tabela 12).

Tabela 12: Densidade populacional por Regional

\begin{tabular}{lcc}
\hline \multicolumn{1}{c}{ REGIONAL } & IMUS Global & $\begin{array}{c}\text { DENSIDADE POPULACIONAL } \\
\left(\mathbf{h a b} / \mathbf{k m}^{2}\right)\end{array}$ \\
\hline Matriz & 0,772 & 5.824 \\
\hline Portão & 0,757 & 7.013 \\
\hline Boqueirão & 0,754 & 5.672 \\
\hline Cajuru & 0,752 & 5.579 \\
\hline Boa Vista & 0,742 & 3.585 \\
\hline Santa Felicidade & 0,740 & 3.470 \\
\hline CIC & 0,735 & 3.499 \\
\hline Bairro Novo & 0,734 & 2.762 \\
\hline Pinheirinho & 0,733 & 3.015 \\
\hline
\end{tabular}

As quatro Regionais com maiores resultados no índice são também as com maiores densidades populacionais. Certamente esse não é o único fator responsável pelo resultado final obtido, mas influi diretamente em outras condicionais, como a densidade das conexões viárias, ou a população abrangida pelo sistema de transporte público. A Figura 22 mostra a clara influência da densidade populacional sobre o resultado obtido no cálculo do IMUS. Coincidentemente valores mais altos de densidades obtêm melhores resultados no índice, excetuando-se um único ponto que representa um outlier na tendência verificada pelos demais. 


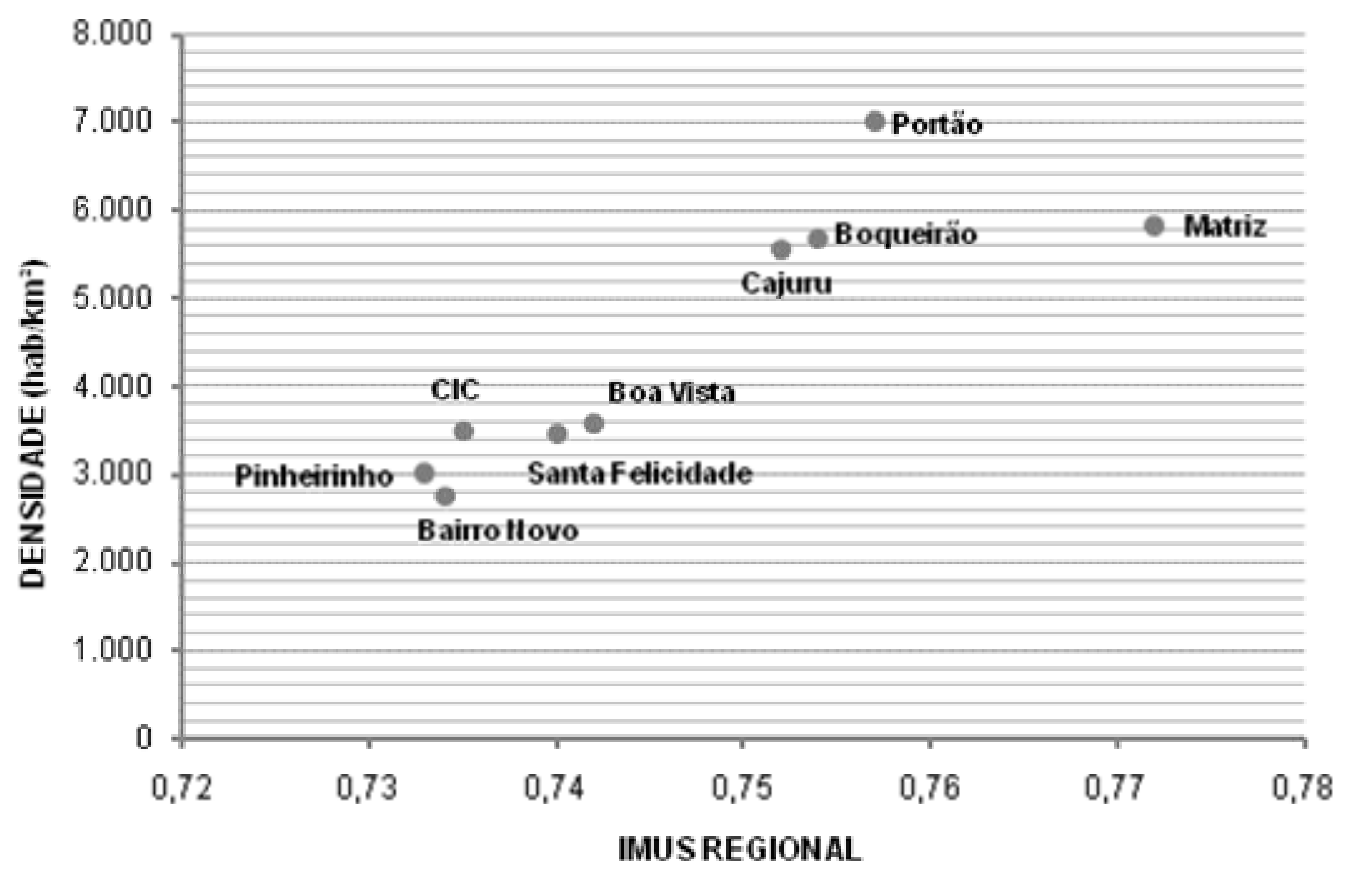

Figura 22: Gráfico comparativo do IMUS Regional pela densidade demográfica de cada Regional

Terminais intermodais é outro indicador que apresentou problemas quanto sua avaliação da cidade. Segundo o Guia de Indicadores do IMUS (COSTA, 2008) o indicador em questão corresponde à porcentagem dos terminais de transporte urbano/metropolitano de passageiros que permitem a integração física de dois ou mais modos de transporte público. No entanto Curitiba apresenta um único modo de transporte público: o ônibus. E apesar de ser reconhecida pelo bom funcionamento desse, a cidade foi bastante desfavorecida pelo índice, recebendo o score zero.

A proposta do IMUS é avaliar a mobilidade de qualquer cidade, independente de seu porte. Porém esse indicador representa um problema, pois nem todas as cidades possuem as mesmas necessidades quanto ao sistema de transporte. Isso significa que a utilização de mais de um modo para o transporte público nem sempre é necessária. A realidade das cidades de grande porte para as demais é bastante distinta e esse indicador penaliza as cidades que não necessitam de diversificação modal.

No entanto Curitiba é uma cidade de grande porte e que atualmente realiza os projetos para a instalação do metrô, mas que ainda discute a real necessidade de sua implantação, pois talvez sua demanda não seja suficiente para justificar tal investimento. Mas de qualquer forma, a operação do sistema atual supre as 
necessidades de deslocamento da população e o transporte público unimodal é bastante eficiente. Assim percebe-se que $\mathrm{o}$ indicador Terminais intermodais desvalorizou seu sistema de transporte, não considerando suas reconhecidas qualidades.

Considerando que o sistema de transporte público da cidade está fundamentado apenas no modo ônibus, outro indicador acaba sendo desfavorecido: Velocidade média do transporte público. O score obtido não foi tão baixo, porém esse indicador reflete o problema do transporte unimodal pautado sobre um veículo de operação mais lenta que o ferroviário, mesmo trafegando em vias segregadas.

É possível perceber que alguns indicadores não correspondem a todas as realidades urbanas, alguns privilegiam cidades de grande porte com complexas redes de sistemas de transporte, mas também outros privilegiam as cidades pequenas sem grandes problemas de circulação. O índice, dessa forma, acaba equilibrando as condições para abranger a todas as realidades, mas sem favorecer apenas a uma. Dessa forma Curitiba foi desfavorecida por seu porte e também por suas características bastante específicas de planejamento urbano e de transporte. Esse não chega a ser um defeito do índice, mas indica que os problemas identificados devam ser analisados com cautela, pois nem sempre o que parece ser demasiado negativo, o é.

\subsubsection{Indicadores com método de cálculo a ser revisto}

Dentre os 75 indicadores aplicados para o cálculo do IMUS em Curitiba, dois apresentaram problemas quanto ao método de normalização: Fragmentação urbana e Extensão da rede de transporte público.

\section{Indicador 1.3.1 Fragmentação urbana}

O Guia de Indicadores do IMUS (COSTA, 2008) define Fragmentação urbana como sendo a proporção de terra urbanizada contínua do total da área urbanizada do município, ou seja, não cortada por infraestrutura de transporte principal como vias de trânsito rápido (rodovias, vias expressas e vias arteriais), corredores de transporte coletivo, vias para transporte ferroviário ou metroviário de superfície, terminais de 
transporte de grande porte, ou qualquer outra barreira física, natural ou construída, que acarrete em descontinuidade do tecido urbano. A identificação dessas barreiras parte da observação da base cartográfica e viária do município, fotos aéreas, além do conhecimento da realidade local. O score é dado pelo número de blocos identificados, sendo que o valor máximo $(1,00)$ equivale a zero blocos e o valor mínimo (zero) equivale a 20 blocos ou mais.

O problema encontrado nesse indicador é que dificilmente poderá se encontrar uma cidade que atinja o valor máximo, pois o padrão de ocupação humana baseia-se na busca por áreas abastecidas por uma rede hídrica, além das cidades mais antigas que eram edificadas sobre colinas como forma de proteção do território (BENEVOLO, 2001). Considerando essas condições esse indicador parece representar uma utopia.

A aplicação do método estabelecido para o cálculo do indicador em Curitiba resultou na configuração apresentada na Figura 23. É possível perceber que se formaram dois tipos distintos de barreiras: em linha ou em área. As barreiras em linha são avenidas, rodovias, ferrovias ou ainda a hidrografia. Sua transposição pode ser dificultada pela falta de pontes, passarelas ou outro recurso. As barreiras em área representam quadras acima do tamanho padrão para o local em que se encontram e podem ser condomínios, áreas militares, aeroportos, grandes edificações, parques e demais áreas fechadas. 


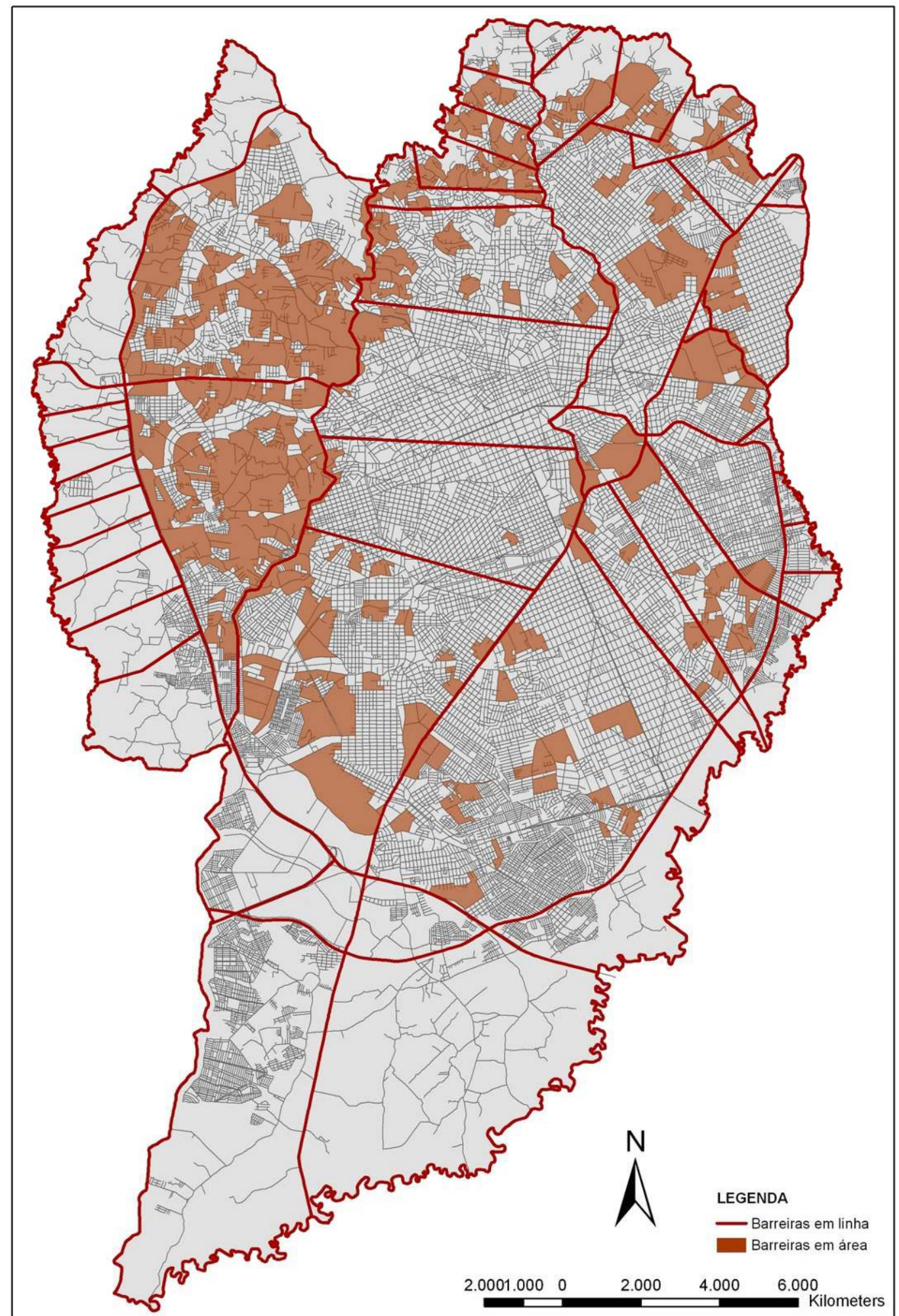

Figura 23: Fragmentação urbana

Fonte: Adaptado de IPPUC (2009)

As regiões sul e extremo oeste da cidade possuem padrões de ocupação do solo bastante diferentes, uma vez que os traços de urbanização são visivelmente pulverizados pelo território. Nesses casos as barreiras em área nem foram 
consideradas, pois cobririam quase todo o espaço urbano. No restante da cidade, o número de manchas que representam a fragmentação do espaço urbano é bastante grande, especialmente a noroeste onde há uma grande concentração de condomínios fechados.

Para compreender melhor a problemática dos valores sugeridos na normalização do indicador, sendo de zero a 19 blocos necessários para garantir score não nulo, a quantidade de áreas identificadas que fragmentam o território curitibano foi de 259 (49 blocos de barreiras em linha e 210 blocos de barreiras em área). O resultado da identificação das barreiras que fragmentam o espaço urbano em Curitiba revela um imenso distanciamento entre as condições reais de uma cidade de grande porte e as condições esperadas pelo Guia de Indicadores do IMUS (COSTA, 2008). Esse problema pode indicar que o método de avaliação do indicador deva ser revisto, uma vez que dificilmente uma cidade irá atingir valores diferentes do mínimo.

\section{Indicador 9.1.1 Extensão da rede de transporte público}

O indicador é definido pelo Guia de Indicadores do IMUS (COSTA, 2008) como sendo a extensão total da rede de transporte público em relação à extensão total do sistema viário urbano. Dessa forma os valores de referência para normalização são: 100 \% ou mais da rede de transporte público em relação à extensão do sistema viário equivale a score 1,00 e até $20 \%$ da rede de transporte público em relação à extensão do sistema viário equivale a score zero.

O problema encontrado em tal normalização é que os valores esperados para score máximo extrapolam a necessidade de qualquer abrangência de um sistema de transporte público. Um sistema de transporte não precisa cobrir uma extensão equivalente às vias de uma cidade para possuir uma área de abrangência total. Isso é justificado pelo indicador Vias para transporte coletivo, pertencente ao domínio INFRAESTRUTURA, que segundo o Guia de Indicadores do IMUS (COSTA, 2008) referese à porcentagem da área urbana da cidade atendida por vias exclusivas ou preferenciais para transporte coletivo por ônibus. O método de cálculo de tal indicador sugere que a área abrangida por um sistema de transporte equivale a um buffer de 500 metros para as vias com circulação de linhas troncais, expressas ou de alta capacidade e um buffer de 300 metros para as vias com circulação de linhas 
alimentadoras integradas à rede troncal. A avaliação do indicador mencionado mostrou que a cidade possui uma cobertura de $90 \%$ de seu território pelo sistema de transporte público. Esse exemplo reflete uma situação em que a exigência do índice extrapola as condições reais de uma cidade comum, o que pode ser observado na Figura 24.

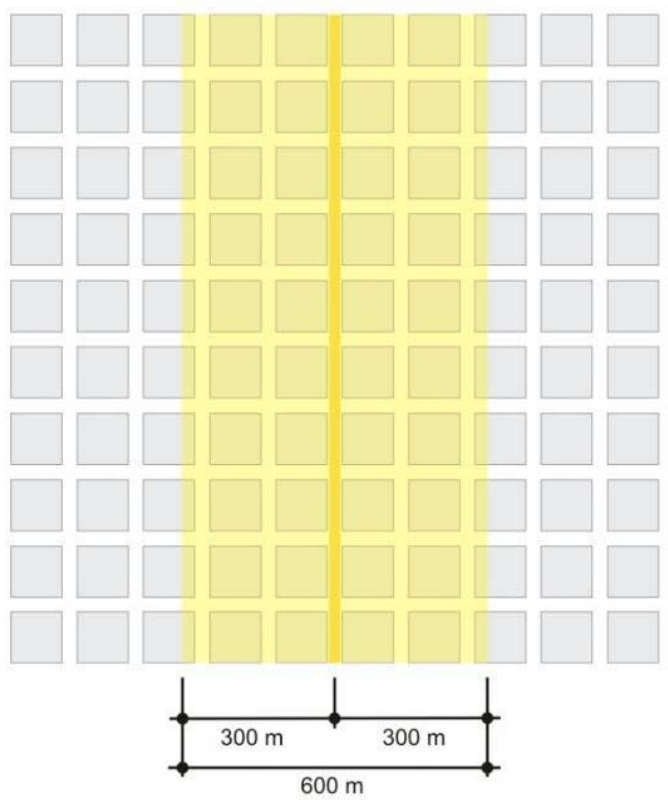

$1,3 \mathrm{~km}$ de vias comportando uma linha alimentadora

$11,8 \mathrm{~km}$ de vias abrangidas pela linha alimentadora

$11 \%$ do sistema possui via para transporte coletivo

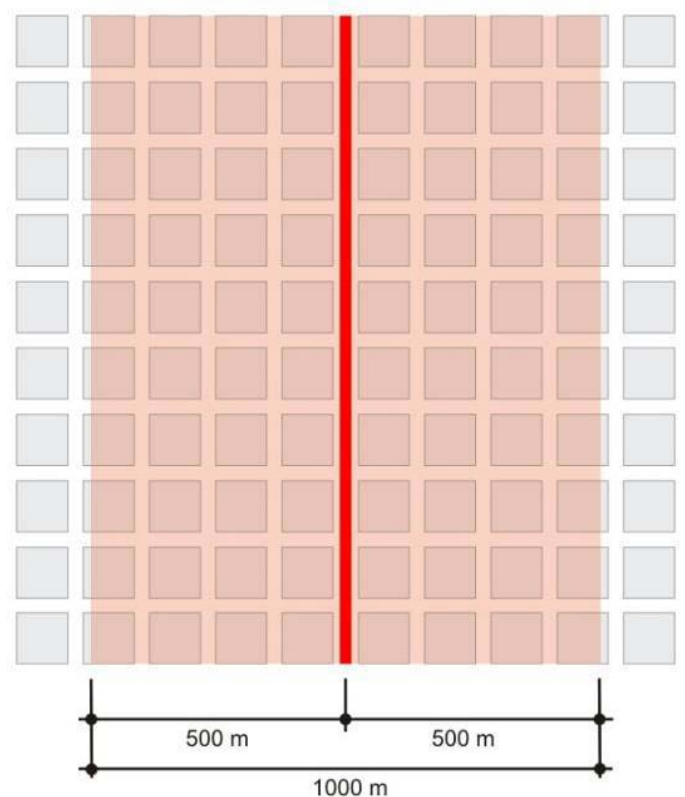

$1,3 \mathrm{~km}$ de vias comportando uma linha troncal, expressa ou de alta capacidade

$17,9 \mathrm{~km}$ de vias abrangidas pela linha troncal, expressa ou de alta capacidade

$7 \%$ do sistema possui via para transporte coletivo

\footnotetext{
- Linha alimentadora

Linha troncal, expressa ou de alta capacidade Área de abrangência da linha alimentadora

Área de abrangência da linha troncal, expressa ou de alta capacidade
}

Figura 24: Cobertura da rede de transporte público

Trata-se de uma representação de dois sistemas viários pertencentes a uma malha com quadras padronizadas de 100 metros. No primeiro exemplo, uma das vias é atendida por uma linha alimentadora, ou convencional, sendo que esta possui uma área de influência com 300 metros para cada um de seus lados. O segundo exemplo trata-se de uma linha troncal, expressa, ou de alta capacidade, sendo que sua área de influência atinge 500 metros para ambos os lados. Percebe-se que a área abrangida pelas linhas vai além das vias por onde transitam os veículos, de forma que se torna desnecessária a existência de outras linhas circulando por todas as demais vias. 
Em Curitiba, onde o sistema de transporte público abrange $90 \%$ da população (para o indicador Vias para transporte coletivo), as vias que recebem a circulação de ônibus atingem apenas $30,6 \%$ do total do sistema viário urbano. Esse valor resultou num score normalizado de 0,13 (para o indicador Extensão da rede de transporte público), um valor bastante baixo para uma cidade com um sistema tão abrangente.

Sem dúvida é preciso considerar a existência de um único modo de transporte público na cidade. Caso houvesse outro, como trem ou metrô, a percentagem da extensão de vias cobertas pelo sistema de transporte público em relação ao total de vias do município seria maior. Porém, esperar que haja total compatibilidade de extensão mostra-se um exagero para qualquer realidade urbana.

\subsection{IMUS como ferramenta de comparação}

A construção de um índice para avaliação de determinada condição, seja desenvolvimento humano (IDH), inflação (IPCA), ou até mesmo mobilidade urbana (IMUS) gera certa expectativa quanto ao desempenho das unidades avaliadas. $O$ interesse em comparar resultados justifica-se pela criação de uma escala de avaliação de qualidade entre cidades distintas, o que pode estimular a identificação de um benchmarking.

Curitiba é uma cidade conhecida por suas soluções em planejamento do transporte público, o que pode torná-la uma referência (benchmark) quanto à mobilidade sustentável. Mas para isso, é preciso comparar os resultados da aplicação do IMUS entre ela e outras cidades. Atualmente, São Carlos é uma das poucas cidades que possui um valor calculado para o índice em questão, de forma a permitir uma comparação.

Dessa forma, estabeleceu-se a comparação de desempenho entre as duas cidades, São Carlos e Curitiba, o que permitirá a identificação de pontos fortes e fracos de uma em relação à outra. Os valores brutos obtidos para o IMUS nas duas cidades são apresentados na Tabela 13, sendo que em Curitiba foram calculados 75 indicadores e em São Carlos esse número foi de 81 indicadores calculados. 
Tabela 13: Resultados do IMUS global e setorial para São Carlos e Curitiba

\begin{tabular}{lcc}
\hline \multirow{2}{*}{ DIMENSÃO DO IMUS } & \multicolumn{2}{c}{ VALOR NORMALIZADO } \\
\cline { 2 - 3 } & São Carlos & Curitiba \\
\hline IMUS $_{\text {Global }}$ & 0,568 & 0,754 \\
\hline IMUS Social $_{\text {S }}$ & 0,192 & 0,255 \\
\hline IMUS $_{\text {Econônica }}$ & 0,191 & 0,250 \\
\hline IMUS Ambiental & 0,186 & 0,249 \\
\hline
\end{tabular}

Fonte: Adaptado de Costa (2008) a partir dos resultados de São Carlos

A observação dos valores diretos permite avaliar que o desempenho de Curitiba foi bastante superior ao de São Carlos, mas em ambas as cidades os resultados dos índices setoriais obedeceram à mesma sequência (do maior para o menor valor): social, econômica e ambiental.

No entanto, tais valores são válidos apenas para identificação das condições de mobilidade nas próprias cidades, consideradas isoladamente. Em caso de comparação de desempenho do índice é preciso considerar apenas os indicadores aplicados em ambas. A Tabela 14 apresenta a lista dos indicadores que foram desconsiderados para o cálculo comparativo, de forma que 0 " $x$ " indica a presença do indicador no cálculo original e o "-“ reflete sua ausência.

Tabela 14: Indicadores não calculados em São Carlos e Curitiba

\begin{tabular}{|c|c|c|c|}
\hline DOMÍNIO & INDICADOR & $\begin{array}{c}\text { SÃO } \\
\text { CARLOS }\end{array}$ & CURITIBA \\
\hline \multirow[t]{2}{*}{ ACESSIBILIDADE } & $\begin{array}{l}\text { Travessias adaptadas a pessoas com } \\
\text { necessidades especiais }\end{array}$ & - & $x$ \\
\hline & Acessibilidade a edifícios públicos & - & - \\
\hline \multirow[t]{2}{*}{ ASPECTOS AMBIENTAIS } & Emissões de CO & $x$ & - \\
\hline & Emissões de $\mathrm{CO}_{2}$ & $x$ & - \\
\hline \multirow[t]{2}{*}{ ASPECTOS SOCIAIS } & Equidade vertical (renda) & $x$ & - \\
\hline & Qualidade de Vida & - & $x$ \\
\hline ASPECTOS POLÍTICOS & Captação de recursos & - & $\mathrm{x}$ \\
\hline INFRAESTRUTUTRA & Sinalização viária & - & - \\
\hline \multirow[t]{5}{*}{ MODOS NÃO-MOTORIZADOS } & Frota de bicicletas & - & $\mathrm{x}$ \\
\hline & Vias com calçadas & - & $x$ \\
\hline & Distância de viagem & $x$ & - \\
\hline & Tempo de viagem & $x$ & - \\
\hline & Número de viagens & $x$ & - \\
\hline PLANEJAMENTO INTEGRADO & Efetivação e continuidade das ações & - & $\mathrm{x}$ \\
\hline \multirow[t]{2}{*}{ TRÁFEGO E CIRCULAÇÃo URBANA } & Prevenção de acidentes & - & - \\
\hline & Congestionamento & - & - \\
\hline \multirow[t]{2}{*}{$\begin{array}{l}\text { SISTEMAS DE TRANSPORTE } \\
\text { URBANO }\end{array}$} & Transporte coletivo $x$ transporte individual & $x$ & - \\
\hline & $\begin{array}{l}\text { Modos não-motorizados } x \text { modos } \\
\text { motorizados }\end{array}$ & $x$ & - \\
\hline
\end{tabular}


Os valores comparativos de São Carlos e Curitiba encontram-se na Tabela 15.

Tabela 15: Resultados do IMUS global e setorial comparativo para São Carlos e Curitiba

\begin{tabular}{lcc}
\hline \multirow{2}{*}{ DIMENSÃO DO IMUS } & \multicolumn{2}{c}{ VALOR NORMALIZADO } \\
\cline { 2 - 3 } & São Carlos & Curitiba \\
\hline IMUS Global & 0,561 & 0,748 \\
\hline IMUS Social & 0,189 & 0,255 \\
\hline IMUS Econômica & 0,188 & 0,248 \\
\hline IMUS & 0,185 & 0,245 \\
\hline
\end{tabular}

Fonte: Adaptado de Costa (2008)

Percebe-se que houve uma ligeira queda nos resultados, pois foram desconsiderados do cálculo indicadores com bom desempenho nas duas cidades. Mas as diferenças permaneceram praticamente as mesmas, mantendo a proporção do IMUS ${ }_{\text {Global }}$ inicial.

A compreensão das diferenças entre os resultados fica clara com a análise da Figura 25 , que apresenta os valores dos domínios isolados de cada um dos municípios. É possível perceber que Curitiba se sobressaiu na grande maioria, porém TRÁFEGO E CIRCULAÇÃo URBANA obteve melhor resultado em São Carlos. A maior diferença percebida é no domínio ASPECTOS Políticos, que obteve em Curitiba valor 2,5 vezes maior do que São Carlos. Planejamento INTEgRado e ASPECtos Socials também apresentaram valores muito divergentes em ambas as cidades.

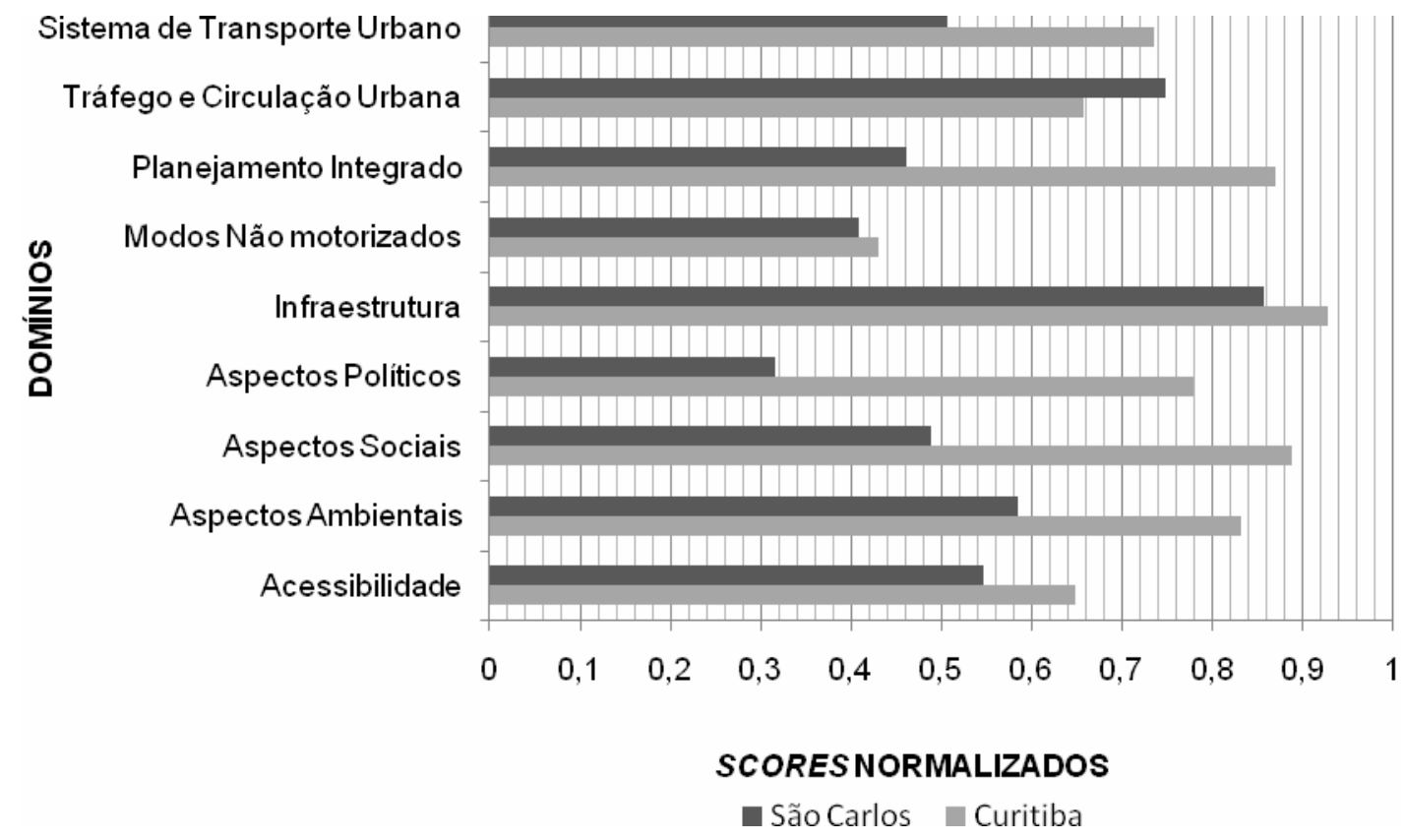

Figura 25: Valores calculados para os Domínios do IMUS comparado para São Carlos e Curitiba 
Como foi mencionado anteriormente, o IMUS possui uma estrutura tão diversificada que acaba por abranger aspectos específicos de cidades grandes e também de pequenas, ora com indicadores que valorizam toda a infraestrutura de uma metrópole e ora privilegiando as pequenas aglomerações urbanas. O domínio em que São Carlos obteve desempenho superior a Curitiba privilegia as cidades de menor porte, pois são as que possuem menos carros em circulação e acabam não sofrendo tanto com congestionamentos. Já Curitiba obteve êxito em domínios que valorizam sua estrutura organizacional administrativa, pautada em planejamento de longo prazo.

De qualquer forma o IMUS mostrou-se uma interessante ferramenta de comparação entre cidades distintas, além de permitir a identificação de um benchmarking quanto à mobilidade sustentável. Essa qualidade é de fundamental importância para o desenvolvimento de políticas públicas pautadas em experiências bem sucedidas, criando a possibilidade da repetição de ações urbanas mais eficientes. 


\section{CONSIDERAÇÕES FINAIS}

Nesse capítulo são apresentadas as principais conclusões da aplicação do Índice de Mobilidade Urbana Sustentável à cidade de Curitiba. Em seguida, são discutidas algumas recomendações para trabalhos futuros.

\subsection{Conclusões}

Os resultados apresentados por esse estudo correspondem à aplicação do método estabelecido pelo Guia de Indicadores do IMUS (COSTA, 2008), que foi desenvolvido para avaliar a mobilidade urbana sustentável nos mais diversos municípios. A análise do cálculo do respectivo índice para a cidade de Curitiba permitiu chegar a algumas conclusões, apresentadas a seguir.

A realização do cálculo do IMUS na cidade de Curitiba mostrou que ela, assim como toda grande cidade, possui problemas de naturezas diversas, não sendo um modelo completo de mobilidade sustentável. Isso se refletiu num valor que não corresponde a 1,00 (o valor máximo atingido pelo índice), mas que foi equivalente a 0,75. Esse resultado é favorável para a cidade e indica que escolhas tomadas ao longo de várias décadas de planejamento foram acertadas, levando a cidade a tornar-se uma referência em boas práticas de planejamento urbano e de transporte. Os domínios que melhor refletiram os bons resultados foram INFRAESTRUTURA, ASPECTOS SOCIAIS e PLANEJAMENTO INTEGRADO.

Quanto à INFRAESTRUTURA, Curitiba demonstrou possuir uma rede viária bastante densa e com alto grau de conectividade, investir na manutenção e infraestrutura de transportes, além de possuir boas condições de pavimentação e grande disponibilidade de vias para o transporte coletivo. Os ASPECTOS SOcIAIS demonstraram que o cidadão é bem informado sobre as práticas gerenciais, assim como é participativo nas decisões políticas, além de acreditar que é elevada a 
qualidade de vida em Curitiba. Finalmente, o domínio PLANEJAMENTO INTEGRAdO mostrou que a cidade possui leis específicas de planejamento e transporte e que acima de tudo essas são cumpridas. Isso também reflete na qualidade da oferta de áreas verdes e equipamentos à população, controle sobre o uso do solo, ocupações irregulares e vazios urbanos, entre outros.

O cálculo do IMUS em Curitiba revelou um ponto muito fraco para a mobilidade urbana: Modos NÃO MotORIZADOS. Apesar de ser conhecida como referência para o transporte público e também apresentar bons investimentos na infraestrutura de transporte, os investimentos direcionados a esses modos ainda são muito reduzidos, assim como os incentivos ao seu uso. Não há grande preocupação em realizar ações para a redução do tráfego motorizado, bem como há limitações na extensão e conectividade das ciclovias, que se preocupam em conectar parques e áreas verdes (indicando a valorização do seu uso com a finalidade de lazer). Com o uso reduzido da bicicleta pela população como modo regular, sua infraestrutura resulta deficitária, não existindo qualquer estacionamento para esses veículos, especialmente nos terminais de transporte público. Outro problema detectado é a extensão reduzida de vias de uso exclusivo para pedestres, que acaba refletindo mais uma vez na valorização dos modos motorizados em detrimento de modos mais sustentáveis.

Os problemas apresentados indicam que a eficiência e abrangência do transporte público parecem ser tão grandes que acabam por desestimular a população a utilizar outros modos. Porém, o que se revela de mais importante é a dependência da população pelos modos motorizados, em particular o automóvel, situação que reflete a elevada taxa de motorização da cidade, que é a maior entre as capitais brasileiras.

A aplicação do IMUS em escala regional revelou que Curitiba tem mantido um padrão de mobilidade intraurbana, apesar das claras diferenças socioeconômicas entre os grupos avaliados. Os resultados isolados dos índices regionais indicaram diferenças percentuais muito pequenas com o índice global municipal. Mas esse resultado pode significar duas situações muito distintas: ou a cidade realmente possui condições similares de mobilidade entre suas diversas regiões, ou os indicadores utilizados para o cálculo não foram capazes de refletir as divergências das mesmas, uma vez que apenas 19 dos 87 indicadores do índice possuem informações desagregadas que permitem o cálculo regional. 
Quanto ao método proposto para o cálculo do IMUS percebeu-se que alguns dos indicadores calculados em Curitiba não corresponderam ao esperado, pois avaliaram de forma negativa aspectos favoráveis da cidade. Densidade populacional urbana, pertencente ao domínio PLANEJAMENTO INTEGRADO, considera que uma densidade demográfica elevada é mais desejável, no entanto essa situação não se verifica em Curitiba. A cidade é famosa por seu rígido controle de uso e ocupação do solo, que obedece aos sucessivos planos de gestão municipal. Tais planos organizaram a cidade de forma a criar áreas com diversos padrões de ocupação, valorizando as áreas de baixa densidade demográfica, livres da intensa verticalização. Esse fato promoveu densidades distintas na extensão urbana, sendo que a média municipal encontra-se abaixo do sugerido como ideal pelo IMUS.

Outro problema também foi verificado com o indicador Terminais intermodais, que equivale à porcentagem de terminais de transporte público urbano que permitem integração entre dois ou mais modos de transporte público. Mais uma vez, escolhas realizadas pelo município ao longo de anos de planejamento refletiram negativamente sobre o desempenho do IMUS em Curitiba, pois o transporte foi pautado apenas sobre um único modo. Isso mostra que o método de avaliação procurou ajustar-se a conceitos de qualidade esperados para qualquer cidade, mas que nem sempre equivalem à realidade num município específico, ou seja, certos casos merecem análises isoladas, que reconheçam as especificidades das diversas realidades urbanas.

O indicador Velocidade média do transporte público também ficou abaixo do estabelecido como satisfatório pelo IMUS. O transporte público urbano de Curitiba é tido como um modelo, mas por fundamentar-se em apenas um modo (ônibus) teve seu desempenho prejudicado. Mesmo com a existência de veículos circulando em vias exclusivas, sistema de bilhetagem prévio ao embarque, cartões inteligentes e estações tubo que permitem embarque em nível, as velocidades operacionais ainda são inferiores a outros modos, como o metroviário.

Ainda é importante reavaliar o método de cálculo de dois indicadores que apresentaram problemas: Fragmentação urbana e Extensão da rede de transporte público. O indicador Fragmentação urbana mostra-se um grande problema para as cidades, sendo que dificilmente renderá valores normalizados positivos. É preciso revisar sua metodologia de cálculo criando uma proposta alternativa. Quanto a Extensão da rede do transporte público, o valor sugerido como ideal encontra-se muito 
acima do necessário para qualquer cidade que utiliza apenas um modo para o sistema de transporte público. Em caso de haver mais de um modo disponível, é provável que a extensão em quilômetros de vias abrangidas pelo sistema encontra-se mais próximo do valor total de vias do município.

Como ferramenta de comparação de desempenho da mobilidade urbana sustentável entre diferentes cidades o IMUS demonstra eficiência, desde que se considerem apenas os indicadores aplicados a ambas as cidades avaliadas. A comparação de valores globais utilizando indicadores diferentes não corresponde a um bom método de comparação, uma vez que remete confrontar elementos distintos. De qualquer maneira, o índice possibilitará a identificação de um benchmarking entre as cidades, criando assim padrões de qualidade da mobilidade urbana sustentável e permitindo a repetição de experiências públicas de sucesso.

\subsection{Recomendações para Trabalhos Futuros}

A contínua aplicação do IMUS em outras cidades mostra-se muito importante para a identificação de falhas e também de pontos positivos do índice. Com três aplicações em cidades de portes distintos: São Carlos, de médio porte, e Curitiba e Brasília, de grande porte, resta ainda a possibilidade de execução do cálculo em uma cidade de pequeno porte. Essa diversificação é necessária para a identificação de possíveis falhas na avaliação e consequentes correções, ou melhorias. Ainda é importante conhecer a realidade e condições de mobilidade oferecidas pelas cidades brasileiras. Não apenas para o reconhecimento de um benchmarking, mas também para a formulação de políticas públicas destinas à sua melhoria e também monitoramento de desempenho dos municípios.

Os resultados obtidos com a aplicação do IMUS em Curitiba revelaram problemas com dois indicadores: Fragmentação urbana e Extensão da rede de transporte público. É essencial que a forma de avaliação proposta pelos mesmos seja revista. Quanto à Fragmentação urbana, há necessidade de remodelação completa do método de cálculo, pois foi verificado que existem padrões diferenciados para as barreiras urbanas, sendo que essas influem de forma muito distintas no espaço urbano. É possível considerar os dos tipos de barreiras identificados, sendo que o score 
represente uma combinação dos mesmos. É difícil dizer que um tipo determinado de barreira seja mais grave para a mobilidade que o outro, pois sua gravidade varia de caso a caso. É possível assim estudar uma maneira de considerar as especificidades de cada situação, tornando o método de avaliação menos genérico. No entanto, é importante manter padrões de avaliação similares, de forma a garantir a possibilidade de comparações entre cidades distintas.

Quanto ao indicador Extensão da rede de transporte público, há necessidade de revisão de seu método de avaliação. A proposta para a obtenção do score do indicador é demasiado exigente, penalizando cidades que possuem sistemas de transporte público bastante abrangentes, mas que utilizam apenas um único modo. É preciso remodelar a proposta, conferindo a ela um grau de exigência menor.

Ainda identificou-se a necessidade de estudar a influência que a densidade populacional exerce sobre o resultado do IMUS, verificada através dos cálculos regionais do índice. Além dessa questão, verifica-se a importância de encontrar maneiras mais simples de calcular indicadores que apresentaram dificuldades em serem calculados, como o caso dos indicadores do domínio ASPECTOS AMBIENTAIS relacionados às emissões de gases. A simplificação do método torna-se uma maneira de permitir que tais questões sejam avaliadas pelas cidades submetidas ao método.

Retomando a proposta já citada de Litman (2009) que estabelece o uso de indicadores como um passo no planejamento global, considera-se necessário realizar consultas aos usuários, como forma de estabelecer objetivos e metas coerentes com as necessidades da população. Assim, o sistema PLANUTS (ZAMBON et al., 2010) é uma evolução das propostas estabelecidas pelo IMUS, uma vez que pauta-se na importância da identificação dos pesos no próprio local onde se está procurando atuar. O aprofundamento de tais pesquisas mostra-se um avanço na metodologia de avaliação de desempenho da mobilidade urbana nos diversos cenários existentes. 


\section{REFERÊNCIAS}

BANISTER, D. (2007). The sustainable mobility paradigm. Transport Policy, v. 15, n. 2, p. 73-80.

BENEVOLO, L. (2001). História da cidade. Perspectiva, São Paulo.

BLACK, J. A.; PAEZ, A.; SUTHANAYA, P.A. (2002) Sustainable urban transportation:performance indicators and some analytical approaches. Journal of Urban Planning and Development, v. 128, n. 4, pp. 184-209. Disponível em: <www.ascelibrary.org/>. Acesso em: 10 mar. 2009.

BRASIL (1988). Constituição da República Federativa do Brasil.

BRASIL (2001). Lei n 10.257, Estatuto da Cidade.

BRASIL (2007). Ministério das Cidades (2007) PlanMob: construindo a cidade sustentável - caderno de referências para elaboração de plano de mobilidade urbana. Brasília: Ministério das Cidades.

BRASIL (2007). Projeto de Lei da Mobilidade Urbana. PL nº 1687.

BOARETO, R. (2008). A política de mobilidade urbana e a construção de cidades sustentáveis. Ciência \& Ambiente, Universidade Federal de Santa Maria, no. 37, p. 7392.

CHOAY, F. (2007). O Urbanismo. Perspectiva, São Paulo.

COMISSÃO MUNDIAL SOBRE MEIO AMBIENTE E DESENVOLVIMENTO (1987). Relatório de meio ambiente. Disponível em: <http://www.un.org/documents/ga/res/42/ares42-187.htm>. Acesso em: 25 mai. 2010. 
COSTA, M. C. (2008). Um índice de mobilidade urbana sustentável. Tese de Doutorado, Escola de Engenharia de São Carlos, Universidade de São Paulo, São Carlos.

DENATRAN (2008). Anuário Estatístico. Departamento Nacional de Trânsito. Disponível em: <http://www.denatran.gov.br/>. Acesso em: 07 ago. 2009.

GNOATO, L. S. (2003). Arquitetura e urbanismo de Curitiba - Transformações do movimento moderno. Tese de Doutorado, Faculdade de Arquitetura, Universidade de São Paulo, São Paulo.

GNOATO, L. S. (2006). Curitiba, cidade do amanhã: 40 anos depois. Algumas premissas teóricas do Plano Wilheim-IPPUC. Arquitextos, São Paulo, 06.072, Vitruvius, mai. 2006. Disponível em: <www.vitruvius.com.br>. Acesso em: 19 jun. 2010.

GREEN, K. (1995). Defending automobility:a critical examination of environmental and social costs of auto use. Rease Foundation. Los Angeles. Disponível em: <http:// reason.org>. Acesso em: 27 nov. 2009.

GUDMUNDSSON, H. (2001). Indicators and performance measures for transportation, environment and sustainability in North America. Relatório do German Marshall Fund Fellowship 2000. Individual Study Tour October 2000. Research Notes n 148.

GUDMUNDSSON, H. (2004). Sustainable transport and performance indicators, In: Hester, R.E. \& Harrison, R.M. (eds), Issues in Environmental Science and Technology, 20, pp. 35-63. Disponível em: <http://forskningsbasen.deff.dk>. Acesso em: 12 dez. 2009 .

GUTIÉRREZ, R. (2007). Los inicios del urbanismo en la Argentina. Parte 2 - La acción de Ernesto Estrada. Arquitextos, São Paulo. Disponível em: <www.vitruvius.com.br>. Acesso em: 05 jul. 2010.

IPPUC (2008). Plano de mobilidade urbana e transporte integrado de Curitiba. Disponível em: <http://www.ippuc.org.br/ippucweb>. Acesso em: 25 abr. 2009.

IPPUC (2009). Site oficial. Disponível em: <http://www.ippuc.org.br>. Acesso em: 28 mar. 2009. 
JACOBS, J. (2007). Morte e vida de grandes cidades. Martins Fontes. São Paulo.

LINDAU, L. A., D. HIDALGO, D. FACCHINI (2010). Curitiba, Brazil: Inauguration of a sixth BRT corridor after 35 years of continuous bus oriented development. Artigo apresentado no $89^{\text {th }}$ Annual Meeting of the Transportation Research Board, Washington, D.C., EUA.

LITMAN, T. (1999). Exploring the paradigm shifts needed to reconcile transportation and sustainability objectives. Transportation Research Record 1670, n. 99, p. 648.

LITMAN, T. (2009).Well weasured - developing indicators for comprehensive and sustainable transport planning. Victoria Transport Policy Institute, Canada, August 2009. www.vtpi.org/wellmeas.pdf. Acesso em: 26 jul. 2009.

LITMAN, T., BURWELL, D. (2006). Issues in sustainable transportation. Journal Global Environmental Issues, v. 6, n. 4, p. 331-347.

LÓPEZ-LAMBAS, M. E., CORAZZA, M. V., MONZON, A., MUSSO A.(2010). Urban mobility plans throughout Europe: a definitive challenge towards sustainability. Artigo apresentado no $89^{\text {th }}$ Annual Meeting of the Transportation Research Board, Washington, D.C, EUA.

MACLAREN, V. W. (1996). Urban sustainability reporting. Journal of the American Planning Association, Chicago, v. 62, n. 2, p. 184-202.

MAY, T.,CRASS, M.. (2007) Sustainability in transport - implications for policy makers. Artigo apresentado no $86^{\text {th }}$ Annual Meeting of the Transportation Research Board, Washington, D.C.

MINISTÉRIO DAS CIDADES (2007). PlanMob: construindo a cidade sustentável caderno de referências para elaboração de planos de mobilidade urbana. Brasília: Ministério das Cidades.

MIRANDA, H. F., MANCINI, M. T., AZEVEDO FILHO M. A. N., ALVES, V. F. B., RODRIGUES DA SILVA, A. N. (2009). Barreiras para a implantação de planos de mobilidade. Artigo apresentado no XXIII Congresso de Ensino e Pesquisa em Transportes, Vitória, Brasil. 
MITCHELL, B. (2008). Cidades engasgam com automóveis. Mega Cidades, OESP (entrevista). Disponível em: <www.estadao.com.br>. Acesso em: 30 mai. 2010.

MUNFORD, L. (1998). A cidade na história - suas origens, transformações e perspectivas, Martins Fontes, São Paulo.

PONTES, T. F. (2010). Avaliação da mobilidade urbana na área metropolitana de Brasília. Dissertação de Mestrado, Faculdade de Arquitetura e Urbanismo, Universidade Federal de Brasília, Brasília.

RODRIGUES DA SILVA, A. N., COSTA, M. S. e MACEDO, M. H. (2008). Multiple views of sustainable urban mobility: The case of Brazil. Transport Policy, v. 15, n. 6, p. 350-360.

SOUZA, M. L. de (2003). Mudar a cidade: uma introdução crítica ao planejamento e à gestão urbanos. $2^{\mathrm{a}}$. Ed., Rio de Janeiro: Bertrand Brasil.

STEG, L., GIFFORD, R. (2005). Sustainable transportation and quality of life. Journal of Transport Geography, n. 13, p. 59-69.

TRB (2008). Sustainable transportation indicators: a recommended program to define a standard set of indicators or sustainable transportation planning. transportation research board (TRB), Sustainable Transportation Indicators (STI), Subcommittee (TRB Subcommittee ADD40 [1]), Janeiro, 2008. Disponível em: <http://www.vtpi.org/sustain/sti.pdf>. Acesso em: 3 jul. 2009.

WWF (2010). Pegada ecológica? O que é isso? Disponível em: <http://www.wwf.org.br/wwf brasil/pegada ecologica/>. Acesso em: 15 jul. 2010.

ZAMBON, K. L., MAGAGNIN, R. C., MANGIERI, R. L., RODRIGUES DA SILVA, A. N. (2010). Incorporando a participação popular ao índice de mobilidade urbana sustentável através da WWW. Artigo apresentado no IV Congresso Luso-Brasileiro para o Planejamento Urbano, Regional, Integrado, Sustentável, Faro, Portugal. 
ANEXO - MEMÓRIA DE CÁLCULO 


\section{ACESSIBILIDADE}

\subsection{Acessibilidade aos sistemas de transporte}

\subsubsection{Acessibilidade ao transporte público}

\section{A. Definição}

Porcentagem da população urbana residente na área de cobertura de um ponto de acesso aos serviços de transporte público, considerando todos os modos disponíveis.

\section{B. Fontes de Dados}

Base georreferenciada localizando os pontos de ônibus, fornecida pelo IPPUC (2009);

Base georreferenciada de Setores Censitários do IBGE (2000).

\section{Método de Cálculo}

Ferramentas auxiliar: Planilhas eletrônicas e Sistema de Informações Geográficas;

Compatibilização dos dados fornecidos pela empresa operadora de transporte público com os dados da base SAAE possibilitando a criação de um arquivo geográfico para os pontos de ônibus.

Uso em conjunto de um arquivo geográfico com os pontos de ônibus com a base de setores censitários do IBGE.

Criação de um buffer ao redor de cada ponto de ônibus com raios de 500 e 300 $\mathrm{m}$, considerando junção das áreas sobrepostas.

Cálculo dos domicílios na área total coberta pelo buffer:455.970 domicílios;

Total de domicílios no município: 477.334 domicílios.
O Score é obtido pela razão entre população total da camada de buffer e a população total do município.

\section{Score}

$95,13 \%$

\section{E. Normalização}

0,95

\begin{tabular}{ll}
\hline Score & $\begin{array}{l}\text { Valores de Referência } \\
\text { Porcentagem da população urbana residente na área de cobertura de pontos } \\
\text { de acesso ao transporte público }\end{array}$ \\
\hline 1,00 & $100 \%$ \\
\hline 0,75 & $77,5 \%$ \\
\hline 0,50 & $55 \%$ \\
\hline 0,25 & $32,5 \%$ \\
\hline 0,00 & Até 10\% \\
\hline
\end{tabular}

1.1.2 Transporte público para pessoas com necessidades especiais

\section{A. Definição}

Porcentagem dos veículos da frota municipal de transporte público por ônibus adaptada para pessoas com necessidades especiais e restrições de mobilidade.

\section{B. Fontes de Dados}

DIRETRAN , URBS (2009). 


\section{Método de Cálculo}

Levantamento do número total de veículos que compõem a frota municipal de transporte público por ônibus, incluindo a RIT: 2.500 .

Levantamento do número de veículos componentes da frota municipal adaptados para transporte de pessoas com necessidades especiais e restrições de mobilidade: 1.750 (embarque em nível e elevadores).

Levantamento da existência de serviço especial de transporte para pessoas com necessidades especiais:

Sistema Integrado de Transporte para o Ensino Especial (SITES)

Empresas de ônibus: 9;

Total da Frota: 53 veículos;

Linhas operantes: 33 diretas e 20 via terminal;

Equipamento específico: um terminal exclusivo;

Passageiros transportados: 1165 por linhas diretas e 1094 passam pelo terminal.

\section{Score}

$70 \%$ dos veículos adaptados e também há serviços especiais para transporte de pessoas com necessidades especiais.

\section{E. Normalização}

\begin{tabular}{ll}
\hline Score & $\begin{array}{l}\text { Valores de Referência } \\
\text { Porcentagem da frota municipal de ônibus urbano adaptada para } \\
\text { pessoas com necessidades especiais ou restrições de mobilidade }\end{array}$ \\
\hline 1,00 & $\begin{array}{l}\text { Mais de 75\% (ou há serviços especiais para transporte de } \\
\text { pessoas com necessidades especiais) }\end{array}$ \\
\hline 0,75 & $75 \%$ \\
\hline 0,50 & $50 \%$ \\
\hline 0,25 & $\begin{array}{l}\text { 35\% (ou não há serviços especiais para transporte de pessoas com } \\
\text { necessidades especiais) }\end{array}$ \\
\hline
\end{tabular}

\subsubsection{Despesas com Transportes}

\section{A. Definição}

Porcentagem da renda mensal pessoal (ou do domicilio) gasta com transporte público.

\section{B. Fontes de Dados}

IBGE - PNAD (2006), URBS e ANTP (2009).

\section{Método de Cálculo}

Informações obtidas a partir das fontes de dados.

\section{Score}

$8,65 \%$

\section{E. Normalização}




\begin{tabular}{ll}
\hline Score & $\begin{array}{l}\text { Valores de Referência } \\
\text { Porcentagem da renda mensal pessoal (ou domiciliar) relativa a } \\
\text { despesas com transporte público }\end{array}$ \\
\hline 1,00 & $\begin{array}{l}\text { Mais de } 75 \% \text { (ou há serviços especiais para transporte de } \\
\text { pessoas com necessidades especiais) }\end{array}$ \\
\hline 0,75 & Até $5 \%$ \\
\hline 0,50 & $10 \%$ \\
\hline 0,25 & $15 \%$ \\
\hline 0,00 & Mais de $20 \%$ \\
\hline
\end{tabular}

\subsection{Acessibilidade Universal}

\subsubsection{Travessias adaptadas para pessoas com necessidades especiais}

\section{A. Definição}

Porcentagem das travessias de pedestres da rede viária principal adaptadas e atendendo aos padrões de conforto e segurança para pessoas com necessidades especiais e restrições de mobilidade.

\section{B. Fontes de Dados}

Levantamento de campo (2009);

Base Vetorizada de ruas fornecida pelo IPPUC (2009).

\section{Método de Cálculo}

Ferramenta auxiliar: Desenho Assistido por Computador (CAD).

No levantamento, foi observada a ocorrência de guia rebaixada (rampa), piso podotátil e semáforo sonoro para deficientes visuais.

Quando notada a presença desses elementos, os mesmos eram assinalados em

um croqui da travessia.
Os dados coletados foram projetados no software.

Através do software obtemos os seguintes dados:

Número de travessias adaptadas: 50 ;

Número total de travessias: 83;

O score foi obtido através do cálculo do quociente entre o número de travessias adaptadas e o número total de travessias.

\section{Score}

$60,24 \%$

\section{E. Normalização}

0,60

\begin{tabular}{ll}
\hline Score & $\begin{array}{l}\text { Valores de Referência } \\
\text { Porcentagem das travessias da rede viária principal adaptada a } \\
\text { pessoas com necessidades especiais e restrições de mobilidade }\end{array}$ \\
\hline 1,00 & $100 \%$ \\
\hline 0,75 & $75 \%$ \\
\hline 0,50 & $50 \%$ \\
\hline 0,25 & $25 \%$ \\
\hline 0,00 & 0 \\
\hline
\end{tabular}




\subsubsection{Acessibilidade aos espaços abertos}

\section{A. Definição}

Porcentagem da população urbana residente próxima a áreas abertas (áreas verdes ou de lazer), considerando os seguintes parâmetros:

Até 500 metros de praças, playgrounds e outras áreas de recreação de pequeno e médio porte;

Até 1000 metros de parques urbanos.

\section{B. Fontes de Dados}

Base Georreferenciada de Setores Censitários do IBGE (2000);

Croquis do Censo 2000 contendo as áreas verdes do município.

\section{Método de Cálculo}

Criação de um buffer ao redor de cada área com largura de 500 m para áreas de lazer com menos de 5 ha e $1000 \mathrm{~m}$ para áreas de lazer de dimensão igual ou superior a 5 há.

Cálculo dos domicílios na área total coberta pelo buffer - 391.197

Domicílios no município segundo o Censo (2000) - 479.334.

A razão entre a população contida no buffer e a população urbana do município fornece o score.

\section{Score}

$81,61 \%$

\section{E. Normalização}

0,82

\begin{tabular}{ll}
\hline Score & $\begin{array}{l}\text { Valores de Referência } \\
\text { Porcentagem da população urbana que reside na área de } \\
\text { influência de espaços verdes e de recreação }\end{array}$ \\
\hline 1,00 & $100 \%$ \\
\hline 0,75 & $75 \%$ \\
\hline 0,50 & $50 \%$ \\
\hline 0,25 & $25 \%$ \\
\hline 0,00 & 0 \\
\hline
\end{tabular}

1.2.3 Vagas de estacionamento para pessoas com necessidades especiais

\section{A. Definição}

Porcentagem de vagas em estacionamentos públicos para pessoas com necessidades especiais.

\section{B. Fontes de Dados}

DIRETRAN (2009), Lei Federal $n^{\circ} 10.098 / 2000$

\section{Método de Cálculo}

Levantamento do número total de vagas em estacionamentos rotativos no anel central do município: 8.195 .

Levantamento do número de vagas destinadas a pessoas com necessidades especiais e restrições de mobilidade em estacionamentos rotativos do anel central: 77.

Cálculo da proporção do número de vagas destinadas a pessoas com necessidades especiais pelo número total de vagas: $0,94 \%$. 
Pela ABNT NBR 9050/2004, o número de vagas para estacionamento de veículos que conduzam ou sejam conduzidos por pessoas com deficiência deve ser estabelecido conforme a referência a seguir:

Até 10: 0;

De 11 a 100: 1 ;

Acima de 100: $1 \%$

Há disponibilidade de vagas para pessoas com necessidades especiais em número inferior aos valores estabelecidos por lei específica (ou indicados na NBR 9050).

\section{Score}

\section{E. Normalização}

\begin{tabular}{ll}
\hline Score & Valores de Referência \\
\hline 1,00 & $\begin{array}{l}\text { Há disponibilidade de vagas para pessoas com necessidades } \\
\text { especiais em número superior aos valores estabelecidos por lei } \\
\text { específica (ou indicados na NBR 9050) e estas se encontram } \\
\text { devidamente sinalizadas e dimensionadas }\end{array}$ \\
\hline $\begin{array}{l}\text { Há disponibilidade de vagas para pessoas com necessidades } \\
\text { especiais em número superior aos valores estabelecidos por lei } \\
\text { específica (ou indicados na NBR 9050), porém as vagas estão mal } \\
\text { sinalizadas ou não apresentam as dimensões adequadas }\end{array}$ \\
\hline $\begin{array}{l}\text { Há disponibilidade de vagas para pessoas com necessidades } \\
\text { especiais em número igual aos valores estabelecidos por lei }\end{array}$ \\
$\begin{array}{l}\text { específica (ou indicados na NBR 9050) e estas se encontram } \\
\text { devidamente sinalizadas e dimensionadas }\end{array}$ \\
$\begin{array}{l}\text { Há disponibilidade de vagas para pessoas com necessidades } \\
\text { especiais em número igual aos valores estabelecidos por lei } \\
\text { específica (ou indicados na NBR 9050), porém as vagas estão mal } \\
\text { sinalizadas ou não apresentam as dimensões adequadas }\end{array}$ \\
\hline $\begin{array}{l}\text { Há disponibilidade de vagas para pessoas com necessidades } \\
\text { especiais em número inferior aos valores estabelecidos por lei } \\
\text { específica (ou indicados na NBR 9050) }\end{array}$ \\
\hline $\begin{array}{l}\text { Não há disponibilidade de vagas para pessoas com necessidades } \\
\text { especiais em estacionamentos públicos }\end{array}$ \\
\hline
\end{tabular}




\subsubsection{Acessibilidade a edifícios públicos}

\section{A. Definição}

Porcentagem de edifícios públicos adaptados para acesso e utilização de pessoas com necessidades especiais ou restrições de mobilidade.

\section{B. Fontes de Dados}

Prefeitura Municipal (Secretaria de Obras, Edificações, Planejamento, Educação, Administração, Ação Social, entre outras), órgãos da administração pública estadual e federal, órgãos de preservação do patrimônio.

\section{Método de Cálculo}

A insuficiência de dados impossibilitou a execução do cálculo deste indicador.

\section{Score}

\section{E. Normalização}

\begin{tabular}{ll}
\hline Score & $\begin{array}{l}\text { Valores de Referência } \\
\text { Porcentagem dos edifícios públicos adaptados para acesso de } \\
\text { pessoas com necessidades especiais ou restrição de mobilidade }\end{array}$ \\
\hline 1,00 & $100 \%$ \\
\hline 0,75 & $75 \%$ \\
\hline 0,50 & $50 \%$ \\
\hline 0,25 & $25 \%$ \\
\hline 0,00 & 0 \\
\hline
\end{tabular}

\subsubsection{Acessibilidade aos serviços essenciais}

\section{A. Definição}

Porcentagem da população urbana residente até 500 metros de distância de serviços essenciais, entendidos aqui como equipamentos de saúde de atendimento primário e equipamentos de educação infantil e ensino fundamental, públicas e particulares.

\section{B. Fontes de Dados}

Base georreferenciada do município fornecida pelo IPPUC (2009).

Base georreferenciada de Setores Censitários do IBGE, fornecida pelo IPPUC (2000).

Base georreferenciada dos equipamentos de saúde e educação, fornecida pelo IPPUC (2009).

\section{Método de Cálculo}

Ferramenta auxiliar: Planilhas eletrônicas e Sistema de Informação Geográfica; Efetuada a unificação das bases de equipamentos de saúde e educação para a seleção dos equipamentos de interesse:

Postos de saúde e unidades de demais atendimento;

Escolas de educação infantil e ensino fundamental, públicas ou particulares.

Criação de um buffer ao redor de cada equipamento com raio de $500 \mathrm{~m}$, considerando junção das áreas sobrepostas.

Cálculo dos domicílios na área total coberta pelo buffer - 413.769 .

Total de domicílios segundo o Censo (2000) - 479.334.

\section{Score}




\section{E. Normalização}

0,85

\begin{tabular}{ll}
\hline Score & $\begin{array}{l}\text { Valores de Referência } \\
\text { Porcentagem da população urbana residente até } 500 \text { metros de } \\
\text { um equipamento de saúde e/ou educação }\end{array}$ \\
\hline 1,00 & $100 \%$ \\
\hline 0,75 & $77,5 \%$ \\
\hline 0,50 & $55 \%$ \\
\hline 0,25 & $32,5 \%$ \\
\hline 0,00 & Até $10 \%$ \\
\hline
\end{tabular}

\subsection{Barreiras físicas}

\subsubsection{Fragmentação urbana}

\section{A. Definição}

Proporção de terra urbanizada contínua do total da área urbanizada do município, ou seja, não cortada por infraestrutura de transporte principal como vias de trânsito rápido (rodovias, vias expressas e vias arteriais), corredores de transporte coletivo, vias para transporte ferroviário ou metroviário de superfície, terminais de transporte de grande porte, ou qualquer outra barreira física, natural ou construída, que acarrete em descontinuidade do tecido urbano.

\section{B. Fontes de Dados}

Base georreferenciada do município fornecida pelo IPPUC (2009)

\section{Método de Cálculo}

Ferramentas auxiliares: Sistema de Informações Geográficas.

Identificação e delimitação na base geográfica fornecida dos elementos fragmentados:

Rios;

Rodovias;

Ferrovias.

Junção de áreas contíguas e identificação das grandes áreas resultantes (blocos ou subdivisões)

\section{Score}

Mais de 20 blocos.

\section{E. Normalização}

0,00

\begin{tabular}{ll}
\hline Score & $\begin{array}{l}\text { Valores de Referência } \\
\text { Número de subdivisões (parcelas) da área urbanizada do } \\
\text { município em função da infraestrutura de transportes }\end{array}$ \\
\hline 1,00 & $0(100 \%$ da área urbanizada é contínua) \\
\hline 0,75 & 5 \\
\hline 0,50 & 10 \\
\hline 0,25 & 15 \\
\hline 0,00 & 20 ou mais \\
\hline
\end{tabular}


1.4 Legislacão para pessoas com necessidades especiais

\subsubsection{Ações para acessibilidade universal}

\section{A. Definição}

Existência e tipos de ações, medidas, programas ou instrumentos, incluindo campanhas, projetos, legislação e normas técnicas destinadas à promoção de acessibilidade universal.

\section{B. Fontes de Dados}

IPPUC e URBS (2009).

\section{Método de Cálculo}

Busca de ações, programas ou instrumentos voltados à promoção da acessibilidade universal, implantadas ou em desenvolvimento em nível municipal:

O município dispõe de campanhas educativas ou de sensibilização;

O município dispõe de programas ou campanhas formalizadas para acessibilidade universal, e também desenvolve ações pontuais, tais como: construção de rampas de acessibilidade às calçadas,

principalmente nos cruzamentos da região central e, nas principais vias de alguns bairros, implantação de faixas de segurança com piso podotátil;

A prefeitura de Curitiba possui legislação referente à acessibilidade universal que recomenda as normas da ABNT

Identificação do score segundo estes dados.

\section{Score}

O município dispõe de legislação específica, normas técnicas, recomendações, programas de iniciativa pública e campanhas de educação e sensibilização para acessibilidade universal.

\section{E. Normalização}

1,00

\begin{tabular}{ll}
\hline Score & Valores de Referência \\
\hline 1,00 & $\begin{array}{l}\text { O município dispõe de legislação específica, normas técnicas, } \\
\text { recomendações, programas de iniciativa pública e campanhas de } \\
\text { educação e sensibilização para acessibilidade universal }\end{array}$ \\
\hline 0,75 & $\begin{array}{l}\text { O município dispõe de legislação específica, normas técnicas, } \\
\text { recomendações e ações ou programas de iniciativa pública para } \\
\text { acessibilidade universal }\end{array}$ \\
\hline 0,50 & $\begin{array}{l}\text { O município dispõe de legislação específica, normas técnicas e } \\
\text { recomendações para acessibilidade universal }\end{array}$ \\
\hline 0,25 & $\begin{array}{l}\text { O município dispõe de legislação específica sobre acessibilidade } \\
\text { universal }\end{array}$ \\
\hline 0,00 & $\begin{array}{l}\text { O município não dispõe de qualquer ação ou instrumento para } \\
\text { acessibilidade universal }\end{array}$ \\
\hline
\end{tabular}




\section{ASPECTOS AMBIENTAIS}

\subsection{Controle dos Impactos no Meio Ambiente}

\subsubsection{Emissões de CO}

\section{A. Definição}

Emissões anuais de monóxido de carbono (CO) por veículos automotores.

\section{B. Fontes de Dados}

Os dados necessários não foram obtidos.

\section{Método de Cálculo}

Pela ausência de dados esse indicador não foi calculado.

D. Score

\section{E. Normalização}

\section{Valores de Referência}

Parâmetro de controle: Quilometragem anual percorrida pela frota municipal de veículos leves em área urbana vezes o limite para níveis de emissão de CO para veículos leves novos $(2,0 \mathrm{~g} / \mathrm{km})+$ quilometragem anual percorrida pela frota municipal de veículos ciclomotores em área urbana vezes o limite para níveis de emissão de CO para ciclomotores novos $(5,5 \mathrm{~g} / \mathrm{km}$,

\section{respectivamente)}

\begin{tabular}{ll}
\hline 1,00 & $\begin{array}{l}\text { A emissão de CO anual por veículos automotores é igual ou } \\
\text { inferior ao parâmetro de controle }\end{array}$ \\
\hline 0,75 & $\begin{array}{l}\text { Estudo de impacto ambiental para projetos de transportes e } \\
\text { mobilidade urbana e define medidas compensatórias ou } \\
\text { mitigadoras }\end{array}$ \\
\hline 0,50 & $\begin{array}{l}\text { Estudo de impacto ambiental e estudo de impacto de vizinhança } \\
\text { para projetos de transportes e mobilidade urbana, mas não define } \\
\text { medidas compensatórias ou mitigadoras }\end{array}$ \\
\hline 0,25 & $\begin{array}{l}\text { Estudo de impacto ambiental para projetos de transportes e } \\
\text { mobilidade urbana, mas não define medidas compensatórias ou } \\
\text { mitigadoras }\end{array}$ \\
\hline 0,00 & $\begin{array}{l}\text { O município não exige qualquer estudo ou medida mitigadora } \\
\text { sobre impactos dos sistemas de transportes e mobilidade urbana }\end{array}$ \\
\hline
\end{tabular}

\subsubsection{Emissões de $\mathrm{CO}_{2}$}

\section{A. Definição}

Emissões anuais de dióxido de carbono $\left(\mathrm{CO}_{2}\right)$ por veículos automotores.

\section{B. Fontes de Dados}

Os dados necessários não foram obtidos

\section{Método de Cálculo}

Pela ausência de dados esse indicador não foi calculado.

D. Score 


\section{E. Normalização}

\begin{tabular}{ll}
\hline Score & Valores de Referência \\
\hline 1,00 & $\begin{array}{l}\text { A emissão de } \mathrm{CO}_{2} \text { anual por veículos automotores é igual ou } \\
\text { inferior ao parâmetro de controle }\end{array}$ \\
\hline 0,75 & $\begin{array}{l}\text { A emissão de } \mathrm{CO}_{2} \text { anual por veículos automotores é } 25 \% \text { maior } \\
\text { que o parâmetro de controle }\end{array}$ \\
\hline 0,50 & $\begin{array}{l}\text { A emissão de } \mathrm{CO}_{2} \text { anual por veículos automotores é } 50 \% \text { maior } \\
\text { que o parâmetro de controle }\end{array}$ \\
\hline 0,25 & $\begin{array}{l}\text { A emissão de } \mathrm{CO}_{2} \text { anual por veículos automotores é } 75 \% \text { maior } \\
\text { que o parâmetro de controle }\end{array}$ \\
\hline 0,00 & $\begin{array}{l}\text { A emissão de } \mathrm{CO}_{2} \text { anual por veículos automotores é } 100 \% \text { maior } \\
\text { que parâmetro de controle }\end{array}$ \\
\hline
\end{tabular}

\subsubsection{População exposta ao ruído de tráfego}

\section{A. Definição}

Porcentagem da população urbana exposta a ruído superior a $65 \mathrm{~dB}(\mathrm{~A})$ ocasionado por sistemas de transporte.

\section{B. Fontes de Dados}

Base georreferenciada do município fornecida pelo IPPUC (2009).

Diagnóstico Ambiental do município de Curitiba, obtido no site oficial da Secretaria Municipal de Meio Ambiente (2009).

\section{Método de Cálculo}

Ferramentas auxiliares: Sistema de Informações Geográficas.

Identificação no mapa de Níveis de Pressão Sonora de Acordo com o Zoneamento as áreas sujeitas a ruído superior a $65 \mathrm{~dB}$.
Cruzamento das áreas sujeitas a níveis de ruído mais altos com o número de domicílios:

Total de domicílios urbanos: 477.317;

Total de domicílios em áreas atingidas por ruídos superiores a $65 \mathrm{~dB}$ :

21.443.

\section{Score}

$4,49 \%$

\section{E. Normalização}

0,96

\begin{tabular}{ll}
\hline Score & $\begin{array}{l}\text { Valores de Referência } \\
\text { Porcentagem da população urbana (ou da área em estudo) } \\
\text { exposta a ruído de tráfego superior a } 65 \mathrm{~dB}(\mathrm{~A})\end{array}$ \\
\hline 1,00 & 0 \\
\hline 0,75 & $25 \%$ \\
\hline 0,50 & $50 \%$ \\
\hline 0,25 & $75 \%$ \\
\hline 0,00 & $100 \%$ \\
\hline
\end{tabular}

\subsubsection{Estudos de impacto ambiental}

\section{A. Definição}

Exigência por parte do município de estudos de impacto ambiental, impactos urbanos e de vizinhança para projetos de transportes e mobilidade, incluindo: projetos de infraestrutura viária, terminais de transporte, corredores de transporte 
público, introdução de novas tecnologias, sistemas de média e alta capacidade, entre outros.

\section{B. Fontes de Dados}

Legislação Municipal.

\section{Método de Cálculo}

Verificação das Leis Municipais que tratam dos temas ambientais:

Estudo e Impacto Ambiental: Lei Ordinária n7.833/91, que dispõe sobre a política de proteção, conservação e recuperação do meio ambiente e dá outras providências;

Estudo de Impacto de Vizinhança: Lei Ordinária 11.266/04, que dispõe sobre a adequação do Plano Diretor de Curitiba ao Estatuto da Cidade Lei Federal $\mathrm{n}^{\circ} 10.257 / 01$, para orientação e controle de desenvolvimento integrado do Município.

\section{Score}

Estudo de impacto ambiental e estudo de impacto de vizinhança para projetos de transportes e mobilidade urbana, e define medidas compensatórias ou mitigadoras.

\section{E. Normalização}

\begin{tabular}{ll}
\hline Score & $\begin{array}{l}\text { Valores de Referência } \\
\text { O município exige: }\end{array}$ \\
\hline 1,00 & $\begin{array}{l}\text { Estudo de impacto ambiental e estudo de impacto de vizinhança } \\
\text { para projetos de transportes e mobilidade urbana, e define } \\
\text { medidas compensatórias ou mitigadoras }\end{array}$ \\
\hline 0,75 & $\begin{array}{l}\text { Estudo de impacto ambiental para projetos de transportes e } \\
\text { mobilidade urbana e define medidas compensatórias ou } \\
\text { mitigadoras }\end{array}$ \\
\hline 0,50 & $\begin{array}{l}\text { Estudo de impacto ambiental e estudo de impacto de vizinhança } \\
\text { para projetos de transportes e mobilidade urbana, mas não define } \\
\text { medidas compensatórias ou mitigadoras }\end{array}$ \\
\hline 0,25 & $\begin{array}{l}\text { Estudo de impacto ambiental para projetos de transportes e } \\
\text { mobilidade urbana, mas não define medidas compensatórias ou } \\
\text { mitigadoras }\end{array}$ \\
\hline 0,00 & $\begin{array}{l}\text { O município não exige qualquer estudo ou medida mitigadora } \\
\text { sobre impactos dos sistemas de transportes e mobilidade urbana }\end{array}$ \\
\hline
\end{tabular}

\subsection{Recursos naturais}

\subsubsection{Consumo de combustível}

\section{A. Definição}

Número de litros de gasolina consumido anualmente por pessoa utilizando veículo motorizado individual na área urbana.

\section{B. Fontes de Dados}

Agência Nacional de Petróleo - ANP, Anuário Estatístico (2009); Instituto Paranaense de Desenvolvimento Econômico e Social - IPARDES, Atlas de Desenvolvimento Humano (2007) e Instituto Brasileiro de Geografia e Estatística IBGE, Contagem da População (2007). 


\section{Método de Cálculo}

Vendas, pelas distribuidoras, dos derivados combustíveis de petróleo por Unidade da Federação e produto - 2000-2009 $\left(\mathrm{m}^{3}\right)$ :

Gasolina vendida no Paraná: 1.639.229.000 L

População do Estado do Paraná no período de 2007: 10.686.247 habitantes.

População de Curitiba no período de 2007: 1.851.215 habitantes.

Cálculo da quantidade de combustível comercializado no Estado do Paraná por habitante:

$153,39 \mathrm{~L} / \mathrm{hab}$.

\section{Score}

$153,39 \mathrm{~L} / \mathrm{hab}$

\section{E. Normalização}

0,99

\begin{tabular}{ll}
\hline Score & $\begin{array}{l}\text { Valores de Referência } \\
\text { Consumo anual per capita de gasolina em veículo motorizado } \\
\text { individual }\end{array}$ \\
\hline 1,00 & Inferior a $150 \mathrm{l} / \mathrm{habitante}$ \\
\hline 0,75 & $300 \mathrm{l} / \mathrm{habitante}$ \\
\hline 0,50 & $450 \mathrm{l} / \mathrm{habitante}$ \\
\hline 0,25 & $600 \mathrm{l} / \mathrm{habitante}$ \\
\hline 0,00 & 750 ou mais I/habitante \\
\hline
\end{tabular}

\subsubsection{Uso de energia limpa e combustíveis alternativos}

\section{A. Definição}

Porcentagem de veículos da frota municipal de transporte público (ônibus, microônibus, vans) e semi-público (táxis e serviços especiais) utilizando combustíveis menos poluentes ou fontes de energia alternativa como: gás natural, gás natural líquido, propano, eletricidade, biodiesel, gasolina híbrida ou hidrogênio.

\section{B. Fontes de Dados}

Dados fornecidos pela URBS/ DIRETRAN.

\section{Método de Cálculo}

Levantamento do número total de veículos que compõem a frota municipal de transporte público e semi-público:

Ônibus: 2.220 veículos;

Táxis: 2.252 veículos.

Levantamento do número desses veículos que utilizam combustíveis menos poluentes ou fontes de energia alternativa:

Ônibus: 6 veículos;

Táxis: 1.563 veículos.

Da razão entre o número de veículos que utilizam combustíveis menos poluentes ou fontes de energia alternativa e o número total de veículos que compõem a frota municipal, obtemos o score.

\section{Score}




\section{E. Normalização}

0,35

\begin{tabular}{ll}
\hline Score & $\begin{array}{l}\text { Valores de Referência } \\
\text { Porcentagem da frota municipal de veículos de transporte público } \\
\text { e semi-público que utiliza combustiveis “limpos" ou alternativos }\end{array}$ \\
\hline 1,00 & $100 \%$ \\
\hline 0,75 & $75 \%$ \\
\hline 0,50 & $50 \%$ \\
\hline 0,25 & $25 \%$ \\
\hline 0,00 & 0 \\
\hline
\end{tabular}

3 ASPECTOS SOCIAIS

\subsection{Apoio ao cidadão}

\subsubsection{Informação disponível ao cidadão}

\section{A. Definição}

Existência e diversidade de informação sobre mobilidade e transportes urbanos disponibilizados ao cidadão, incluindo: informações sobre os sistemas de transportes em todas as suas modalidades, serviços de auxílio ao usuário, canais de comunicação para reclamações e denúncias, atendimento on-line, informações sobre condições de tráfego e circulação, entre outros.

\section{B. Fontes de Dados}

Informações disponíveis no endereço oficial da Prefeitura Municipal de Curitiba e IPPUC na Internet (2009), além de informações cedidas pela URNBS e DIRETRAN.

\section{Método de Cálculo}

Verificação das informações disponíveis no endereço oficial da Prefeitura Municipal de Curitiba na Internet sobre transportes e mobilidade urbana: Informação sobre serviços de transporte público: informações disponíveis na Internet e no telefone 156;

Informações sobre condições de trânsito e circulação: Rádio Trânsito (boletins no rádio e na internet) informa sobre acidentes, desvios, situações programadas e emergenciais;

Canais de comunicação para denúncias e reclamações sobre serviços de transporte público: serviços disponíveis na Internet e no telefone 156; Informações sobre planos e projetos de transporte e mobilidade urbana: informações disponíveis na Internet, site da prefeitura, IPPUC e URBS. Identificação do score segundo estes dados.

\section{Score}

Há disponibilidade de informação sobre serviços de transporte público, canais de comunicação para denúncias e reclamações, informações sobre condições de trânsito e circulação e informações sobre planos e projetos de transporte e mobilidade urbana.

\section{E. Normalização}




\begin{tabular}{|c|c|}
\hline \multirow{2}{*}{ Score } & Valores de Referência \\
\hline & Há disponibilidade de: \\
\hline 1,00 & $\begin{array}{l}\text { Informação sobre serviços de transporte público, canais de } \\
\text { comunicação para denúncias e reclamações, informações sobre } \\
\text { condições de trânsito e circulação e informações sobre planos e } \\
\text { projetos de transporte e mobilidade urbana }\end{array}$ \\
\hline 0,75 & $\begin{array}{l}\text { Informação sobre serviços de transporte público, canais de } \\
\text { comunicação para denúncias e reclamações e informações sobre } \\
\text { condições de trânsito e circulação }\end{array}$ \\
\hline 0,50 & $\begin{array}{l}\text { Informação sobre serviços de transporte público e canais de } \\
\text { comunicação para denúncias e reclamações }\end{array}$ \\
\hline 0,25 & Informação sobre serviços de transporte público \\
\hline 0,00 & $\begin{array}{l}\text { Não há disponibilidade de qualquer tipo de informação sobre } \\
\text { transportes e mobilidade para os cidadãos }\end{array}$ \\
\hline
\end{tabular}

\subsection{Inclusão social}

\subsubsection{Equidade vertical (renda)}

\section{A. Definição}

Razão entre o número médio de viagens diárias dos moradores de domicílios mais pobres, entendidos como os domicílios com renda até 3 salários mínimos, e dos moradores dos domicílios mais ricos, entendidos como os domicílios com renda superior a 20 salários mínimos.

\section{B. Fontes de Dados}

Dados não disponíveis.

\section{Método de Cálculo}

Cálculo não realizado pela indisponibilidade de dados.

\section{Score}

\section{E. Normalização}

$-$

\begin{tabular}{ll}
\hline Score & $\begin{array}{l}\text { Valores de Referência } \\
\text { Razão entre o número médio de viagens diárias dos moradores de } \\
\text { domicílios mais pobres e o número médio de viagens diárias dos } \\
\text { moradores de domicílios mais ricos }\end{array}$ \\
\hline 1,00 & 1,00 ou mais \\
\hline 0,75 & 0,75 \\
\hline 0,50 & 0,50 \\
\hline 0,25 & 0,25 \\
\hline 0,00 & 0 \\
\hline
\end{tabular}

\subsection{Educação e cidadania}

\subsubsection{Educação para o desenvolvimento sustentável}

\section{A. Definição}

Existência de ações continuadas de formação e sensibilização, equipamentos públicos específicos, programas e projetos desenvolvidos pelo município em matéria de educação para o desenvolvimento sustentável.

\section{B. Fontes de Dados}

Secretaria Municipal de Educação (2009). 


\section{Método de Cálculo}

Levantamento dos equipamentos, ações e programas em matéria de educação para:

Equipamentos públicos: não há equipamentos específicos, o ambiente das próprias escolas é utilizado para educação ambiental e sustentável; Existem ações continuadas na educação infantil, jovens e adultos e para públicos específicos. Alguns desses programas são: Trilhas da Cidade, Comunidade Escola, Jovens Governantes.

Identificação do score segundo estes dados.

\section{Score}

Ações de formação continuada para crianças, jovens e adultos e promove campanhas de sensibilização para o desenvolvimento sustentável.

\section{E. Normalização}

0,75

\begin{tabular}{ll}
\hline Score & $\begin{array}{l}\text { Valores de Referência } \\
\text { O município dispõe de: }\end{array}$ \\
\hline 1,00 & $\begin{array}{l}\text { Equipamentos específicos, ações de formação continuada para } \\
\text { crianças, jovens e adultos e promove campanhas de } \\
\text { sensibilização para o desenvolvimento sustentável }\end{array}$ \\
\hline 0,75 & $\begin{array}{l}\text { Ações de formação continuada para crianças, jovens e adultos e } \\
\text { promove campanhas de sensibilização para o desenvolvimento } \\
\text { sustentável }\end{array}$ \\
\hline 0,50 & $\begin{array}{l}\text { Ações de formação continuada somente para crianças e promove } \\
\text { campanhas de sensibilização para o desenvolvimento sustentável }\end{array}$ \\
\hline 0,25 & $\begin{array}{l}\text { Promove campanhas de sensibilização para o desenvolvimento } \\
\text { sustentável }\end{array}$ \\
\hline 0,00 & $\begin{array}{l}\text { O município não dispõe de nenhuma ação em matéria de } \\
\text { educação para o desenvolvimento sustentável }\end{array}$ \\
\hline
\end{tabular}

\subsection{Participação Popular}

\subsubsection{Participação na tomada de decisão}

\section{A. Definição}

Incentivo e viabilização por parte da administração municipal para a participação popular nos processos de elaboração, implementação e monitoramento das políticas, ações e projetos de transporte e mobilidade urbana.

\section{B. Fontes de Dados}

Informações disponíveis no endereço oficial da Prefeitura Municipal de Curitiba.

\section{Método de Cálculo}

Avaliação do processo de planejamento e gestão municipal no que diz respeito à participação popular na elaboração, implementação e monitoramento de políticas, ações e projetos de transportes, mobilidade e desenvolvimento urbano. Identificação do score segundo estes dados. 


\section{Score}

Incentivou e viabilizou a participação popular no desenvolvimento de políticas, ações e projetos de transportes, mobilidade e desenvolvimento urbano, em todas as suas etapas (elaboração, implementação e monitoramento).

\section{E. Normalização}

1,00

\begin{tabular}{ll}
\hline Score & $\begin{array}{l}\text { Valores de Referência } \\
\text { A administração municipal: }\end{array}$ \\
\hline 1,00 & $\begin{array}{l}\text { Incentivou e viabilizou a participação popular no desenvolvimento } \\
\text { de políticas, ações e projetos de transportes, mobilidade e } \\
\text { desenvolvimento urbano, em todas as suas etapas (elaboração, } \\
\text { implementação e monitoramento) }\end{array}$ \\
\hline 0,66 & $\begin{array}{l}\text { Incentivou e viabilizou a participação popular no desenvolvimento } \\
\text { de políticas, ações e projetos de transportes, mobilidade e } \\
\text { desenvolvimento urbano, em duas de suas etapas (elaboração, } \\
\text { implementação ou monitoramento) }\end{array}$ \\
\hline 0,33 & $\begin{array}{l}\text { Incentivou e viabilizou a participação popular no desenvolvimento } \\
\text { de políticas, ações e projetos de transportes, mobilidade e } \\
\text { desenvolvimento urbano, somente em uma de suas etapas } \\
\text { (elaboração, implementação ou monitoramento) }\end{array}$ \\
\hline 0,00 & $\begin{array}{l}\text { Não incentivou nem viabilizou a participação popular no } \\
\text { desenvolvimento de quaisquer políticas, ações e projetos de } \\
\text { transportes, mobilidade e desenvolvimento urbano }\end{array}$ \\
\hline
\end{tabular}

3.5 Qualidade de vida

\subsubsection{Qualidade de Vida}

\section{A. Definição}

Porcentagem da população satisfeita com a cidade como local para viver.

\section{B. Fontes de Dados}

Reportagem do jornal Gazeta do Povo: Retrato da Grande Curitiba publicada em março de 2009

\section{Método de Cálculo}

Entrevistas realizadas com a população da cidade em que se fez a seguinte pergunta: você acha que a sua cidade oferece qualidade de vida?

\section{Score}

$80 \%$ dos entrevistados declaram que Curitiba oferece bastante qualidade de vida.

\section{E. Normalização}

0,80

\begin{tabular}{ll}
\hline Score & $\begin{array}{l}\text { Valores de Referência } \\
\text { Porcentagem da população (ou dos entrevistados) considera a } \\
\text { cidade "bom" e "excelente" lugar para se viver }\end{array}$ \\
\hline 1,00 & $100 \%$ \\
\hline 0,75 & $75 \%$ \\
\hline 0,50 & $50 \%$ \\
\hline 0,25 & $25 \%$ \\
\hline 0,00 & 0 \\
\hline
\end{tabular}




\subsection{Integração de ações políticas}

\subsubsection{Integração entre níveis de governo}

\section{A. Definição}

Frequência e grau de integração de ações, programas e projetos de transportes, mobilidade e desenvolvimento urbano desenvolvidos pelo município, em conjunto com o governo estadual e/ou federal.

\section{B. Fontes de Dados}

Instituto de Pesquisa e Planejamento Urbano de Curitiba (2009).

\section{Método de Cálculo}

Levantamento das ações e projetos de transportes e mobilidade realizados no município, desenvolvidos junto ao governo estadual e/ou federal:

Frequentes, envolvendo os governos municipal, estadual e federal. Identificação do score segundo estes dados.

\section{Score}

Frequentes, envolvendo os governos municipal, estadual e federal.

\section{E. Normalização}

0,75

\begin{tabular}{|c|c|}
\hline \multirow{2}{*}{ Score } & Valores de Referência \\
\hline & As ações integradas são: \\
\hline 1,00 & $\begin{array}{l}\text { Muito frequentes, envolvendo os governos municipal, estadual e } \\
\text { federal }\end{array}$ \\
\hline 0,75 & Frequentes, envolvendo os governos municipal, estadual e federal \\
\hline 0,50 & $\begin{array}{l}\text { Pouco frequentes, envolvendo os governos municipal, estadual e } \\
\text { federal }\end{array}$ \\
\hline 0,25 & $\begin{array}{l}\text { Pouco frequentes, envolvendo somente os governos municipal e } \\
\text { estadual }\end{array}$ \\
\hline 0,00 & $\begin{array}{l}\text { As ações integradas entre os governos municipal, estadual e } \\
\text { federal são aras no município }\end{array}$ \\
\hline
\end{tabular}

\subsubsection{Parcerias público-privadas}

\section{A. Definição}

Ações, projetos, serviços ou infraestrutura de transporte urbano viabilizados por meio de parcerias entre o governo municipal e entidades privadas.

\section{B. Fontes de Dados}

Instituto de Pesquisa e Planejamento Urbano de Curitiba (2009).

\section{Método de Cálculo}

Verificação da existência de projetos de transportes e mobilidade urbana, desenvolvidos por meio de parcerias público-privadas:

$$
\text { Já foram implementadas no município. }
$$

Identificação do score segundo estes dados.

\section{Score}

Já foram implementadas no município. 


\section{E. Normalização}

1,00

\begin{tabular}{ll}
\hline Score & $\begin{array}{l}\text { Valores de Referência } \\
\text { Projetos de transportes e mobilidade urbana por meio de parcerias } \\
\text { público-privadas: }\end{array}$ \\
\hline 1,00 & Já foram implementados no município \\
\hline 0,50 & Encontram-se em preparação no município \\
\hline 0,00 & Não estão previstos nem foram implementados no município \\
\hline
\end{tabular}

\subsection{Captação e gerenciamento de recursos}

\subsubsection{Captação de recursos}

\section{A. Definição}

Porcentagem dos recursos municipais para financiamento de projetos de transportes e mobilidade oriundos de taxações aos veículos/usuários, multas ou pedágios urbanos.

\section{B. Fontes de Dados}

Secretaria Municipal de Finanças (2009).

\section{Método de Cálculo}

Foram contabilizados $\mathrm{R} \$ 967.173 .000,00$ disponíveis para investimentos em mobilidade urbana e projetos de transporte público, dos quais $\mathrm{R} \$ 60.785 .000,00$ são obtidos a partir de multas de trânsito.

\section{Score}

$6,28 \%$

\section{E. Normalização}

0,31

\begin{tabular}{ll}
\hline Score & $\begin{array}{l}\text { Valores de Referência } \\
\text { Porcentagem dos recursos municipais para transportes e } \\
\text { mobilidade obtidos por meio de taxações, multa ou pedágios } \\
\text { urbanos }\end{array}$ \\
\hline 1,00 & $20 \%$ ou mais \\
\hline 0,75 & $15 \%$ \\
\hline 0,50 & $10 \%$ \\
\hline 0,25 & $5 \%$ \\
\hline 0,00 & 0 \\
\hline
\end{tabular}

\subsubsection{Investimentos em sistemas de transporte}

\section{A. Definição}

Investimentos em sistemas de transportes e mobilidade urbana feitos pelo município no ano de referência.

\section{B. Fontes de Dados}

Secretaria Municipal de Finanças (2009).

\section{Método de Cálculo}

Levantamento das áreas e tipos de investimentos feitos em sistemas de $\overrightarrow{\vec{v}}$ transportes e mobilidade pelo município no último ano: 
Obras de infraestrutura;

Provisão e melhoria de serviços de transporte coletivo;

Projetos para os modos não-motorizados de transporte;

Ampliação da mobilidade de pessoas com necessidades especiais. Identificação do score segundo estes dados.

\section{Score}

Obras de infraestrutura, investimentos na provisão e melhoria de serviços de transporte coletivo, projetos para os modos não-motorizados de transporte e ampliação da mobilidade de pessoas com necessidades especiais, além de planos de mobilidade urbana.

\section{E. Normalização}

1,00

\begin{tabular}{ll}
\hline Score & $\begin{array}{l}\text { Valores de Referência } \\
\text { Houve investimentos no ano de referência no municipio em: }\end{array}$ \\
\hline 1,00 & $\begin{array}{l}\text { Obras de infraestrutura, investimentos na provisão e melhoria de } \\
\text { serviços de transporte coletivo, projetos para os modos não- } \\
\text { motorizados de transporte e ampliação da mobilidade de pessoas } \\
\text { com necessidades especiais, além de planos de mobilidade } \\
\text { urbana }\end{array}$ \\
\hline 0,75 & $\begin{array}{l}\text { Obras de infraestrutura, investimentos na provisão e melhoria de } \\
\text { serviços de transporte coletivo, modos não-motorizados de } \\
\text { transporte ou ampliação da mobilidade de pessoas com } \\
\text { necessidades especiais }\end{array}$ \\
\hline 0,50 & $\begin{array}{l}\text { Obras de infraestrutura e investimentos na provisão e melhoria de } \\
\text { serviços de transporte coletivo }\end{array}$ \\
\hline 0,25 & $\begin{array}{l}\text { Somente em obras emergenciais, corretivas e preventivas de } \\
\text { infraestrutura de transportes }\end{array}$ \\
\hline 0,00 & $\begin{array}{l}\text { Não houve investimentos em infraestrutura, sistemas de } \\
\text { transportes e mobilidade }\end{array}$ \\
\hline
\end{tabular}

4.2.3 Distribuição dos recursos (coletivo $x$ privado)

\section{A. Definição}

Razão entre os investimentos públicos com infraestrutura para o transporte coletivo e infraestrutura para o transporte privado.

\section{B. Fontes de Dados}

Lei de Diretrizes Orçamentárias, Secretaria Municipal de Finanças (2009).

\section{Método de Cálculo}

Identificação na Lei de Diretrizes Orçamentárias, obtida na Secretaria Municipal de Finanças, os investimentos em infraestrutura para modos coletivos e privados de transporte, quantificando os valores:

Investimentos em infraestrutura para modos coletivos: $\mathrm{R} \$ 39.740 .000,00$;

Investimentos em infraestrutura para modos privados: $\mathrm{R} \$$

196.259.000,00.

Calcular a razão entre modos coletivos pelos modos privados.

\section{Score}

\section{E. Normalização}




\begin{tabular}{ll}
\hline Score & Valores de Referência \\
\hline 1,00 & $\begin{array}{l}\text { I }>1 \text { Os investimentos em infraestrutura para transporte coletivo no } \\
\text { município no ano de referência foram superiores aos } \\
\text { investimentos em infraestrutura para o transporte privado }\end{array}$ \\
\hline 0,75 & $\begin{array}{l}\text { I }=1 \text { Os investimentos em infraestrutura para transporte coletivo } \\
\text { no municipio no ano de referência foram equivalentes aos } \\
\text { investimentos em infraestrutura para o transporte privado }\end{array}$ \\
\hline 0,50 & $\begin{array}{l}\text { 0,5<I<1 Houve investimentos em infraestrutura para transporte } \\
\text { coletivo no município no ano de referência, porém, estes foram um } \\
\text { pouco inferiores aos investimentos em infraestrutura para o } \\
\text { transporte privado }\end{array}$ \\
\hline $\begin{array}{l}0<1 \leq 0,5 \text { Houve investimentos em infraestrutura para transporte } \\
\text { coletivo no município no ano de referência, porém, estes foram } \\
\text { bastante inferiores aos investimentos em infraestrutura para o } \\
\text { transporte privado }\end{array}$ \\
$\begin{array}{l}\text { I=0 Não houve investimentos em infraestrutura para transporte } \\
\text { coletivo no município no ano de referência. Os recursos foram } \\
\text { destinados à provisão, ampliação e manutenção de vias de uso } \\
\text { predominante de automóveis }\end{array}$ \\
\hline 0,00 & $\quad$
\end{tabular}

\subsubsection{Distribuição dos recursos (motorizados $x$ não motorizados)}

\section{A. Definição}

Razão entre os gastos públicos com infraestrutura para os modos não motorizados e infraestrutura para os modos motorizados de transporte.

\section{B. Fontes de Dados}

Lei de Diretrizes Orçamentárias, Secretaria Municipal de Finanças (2009).

\section{Método de Cálculo}

Identificação na Lei de Diretrizes Orçamentárias, obtida na Secretaria Municipal de Finanças, os investimentos em infraestrutura para modos não motorizados e motorizados, quantificando os valores:
Investimentos em infraestrutura para modos não motorizados: $\mathrm{R} \$$

1.771.000,00;

Investimentos em infraestrutura para modos motorizados: R\$ 232.359.000,00.

Calcular a razão entre modos não motorizados e motorizados.

\section{Score}

0,01

\section{E. Normalização}

0,25

\section{Score Valores de Referência}

\begin{tabular}{|c|c|}
\hline 1,00 & $\begin{array}{l}\text { I }>1 \text { Os investimentos em infraestrutura para modos não } \\
\text { motorizados de transporte no município no ano de referência } \\
\text { foram superiores aos investimentos em infraestrutura para os } \\
\text { modos motorizados }\end{array}$ \\
\hline 0,75 & $\begin{array}{l}\text { I = } 1 \text { Os investimentos em infraestrutura para modos não } \\
\text { motorizados de transporte no município no ano de referência } \\
\text { foram equivalentes aos investimentos em infraestrutura para os } \\
\text { modos motorizados }\end{array}$ \\
\hline 0,50 & $\begin{array}{l}0,5<1<1 \text { Houve investimentos em infraestrutura para modos não } \\
\text { motorizados de transporte no município no ano de referência, } \\
\text { porém, estes foram um pouco inferiores aos investimentos em } \\
\text { infraestrutura para os modos motorizados }\end{array}$ \\
\hline 0,25 & $\begin{array}{l}0<1 \leq 0,5 \text { Houve investimentos em infraestrutura para modos não } \\
\text { motorizados de transporte no município no ano de referência, } \\
\text { porém, estes foram bastante inferiores aos investimentos em } \\
\text { infraestrutura para os modos motorizados }\end{array}$ \\
\hline 0,00 & $\begin{array}{l}\text { I = } 0 \text { Não houve investimentos em infraestrutura para modos não } \\
\text { motorizados de transporte no município no ano de referência. Os } \\
\text { recursos foram destinados à provisão, ampliação e manutenção } \\
\text { de vias de uso de veículos }\end{array}$ \\
\hline
\end{tabular}




\begin{tabular}{ll}
\hline Score & $\begin{array}{l}\text { Valores de Referência } \\
\text { O município encontra-se no seguinte estágio no ano de referência: }\end{array}$ \\
\hline 1,00 & $\begin{array}{l}\text { Fase de implantação e efetivação do Plano Diretor de Transporte e } \\
\text { da Mobilidade ou outro instrumento referente à política de } \\
\text { mobilidade urbana }\end{array}$ \\
\hline 0,75 & $\begin{array}{l}\text { Fase de institucionalização do Plano Diretor de Transporte e da } \\
\text { Mobilidade ou outro instrumento referente à política de mobilidade } \\
\text { urbana }\end{array}$ \\
\hline 0,50 & $\begin{array}{l}\text { Fase de desenvolvimento de estudos e projetos relacionados à } \\
\text { elaboração do Plano Diretor de Transporte e da Mobilidade ou } \\
\text { outro instrumento referente à política de mobilidade urbana }\end{array}$ \\
\hline 0,25 & $\begin{array}{l}\text { Fase de mobilização ou contratação de consultoria especializada } \\
\text { para elaboração do Plano Diretor de Transporte e da Mobilidade } \\
\text { ou outro instrumento referente à política de mobilidade urbana }\end{array}$ \\
\hline 0,00 & $\begin{array}{l}\text { O município não possui qualquer política ou plano de mobilidade } \\
\text { urbana em implantação ou em desenvolvimento }\end{array}$ \\
\hline
\end{tabular}

Levantamento da existência ou desenvolvimento de política de transportes e mobilidade em nível local, especialmente no que diz respeito à elaboração do Plano Diretor de Transporte e da Mobilidade:

O município possui um Plano de Mobilidade Urbana aprovado e no início de sua implantação.

\section{Score}

Fase de implantação e efetivação do Plano Diretor de Transporte e da Mobilidade ou outro instrumento referente à política de mobilidade urbana.

\section{E. Normalização}

\section{INFRAESTRUTURA DE TRANSPORTE}

\subsection{Provisão e manutencão da infraestrutura de transportes}

\subsubsection{Densidade e conectividade da rede viária}

\section{A. Definição}

Densidade e conectividade da rede viária urbana.

\section{B. Fontes de Dados}

Base georreferenciada do município fornecida pelo IPPUC (2009). 


\section{Método de Cálculo}

Ferramentas auxiliares:

Área urbana: 430,9 $\mathrm{km}^{2}$, porém foi desconsidera as áreas de APA dentro

do perímetro, resultando numa área de $359,59 \mathrm{~km}^{2}$;

Extensão total do sistema viário na área urbana - 4.485,939 km

Cálculo da densidade da rede viária pelo quociente entra a extensão total das vias urbanas e áreas urbanizadas do município - $12,48 \mathrm{~km} / \mathrm{km}^{2}$.

Criação de malha de pontos de $100 \times 100$ metros cobrindo toda a área onde se desenvolve o sistema viário urbano:

Contagem do número de nós da respectiva malha - 36.203 nós

Contagem do número de nós do sistema viário em relação ao número ideal de nós da área urbana - 23.204 (64\%).

A relação entre os dois resultados fornece o score.

\section{Score}

Alta/Alta

\section{E. Normalização}

1,00

\begin{tabular}{ll}
\hline \multirow{2}{*}{ Score } & $\begin{array}{l}\text { Valores de Referência } \\
\text { Densidade: Baixa }<10 \mathrm{~km} / \mathrm{km}^{2} \text { ou Alta }>10 \mathrm{~km} / \mathrm{km}^{2} \\
\end{array}$ \\
\hline 1,00 & Alta/Alta \\
\hline 0,66 & Baixa/Alta \\
\hline 0,33 & Alta/Baixa \\
\hline 0,00 & Baixa/Baixa \\
\hline
\end{tabular}

\subsubsection{Vias pavimentadas}

\section{A. Definição}

Extensão de vias pavimentadas em relação à extensão total do sistema viário urbano.

\section{B. Fontes de Dados}

Base georreferenciada do município e base das vias por tipo de pavimento, fornecidas pelo IPPUC (2009).

\section{Método de Cálculo}

Ferramentas auxiliares: Planilhas eletrônicas e Sistemas de Informações Geográficas:

Cálculo da extensão total do sistema viário na área urbana - 4.314.102

Identificação das vias não pavimentadas e sua extensão - $432.888 \mathrm{~m}$

Extensão de vias pavimentadas - 3,881,214 m.

O score é obtido pela razão entre a extensão total de vias pavimentadas e a extensão total do sistema viário urbano. 
D. Score

$90,35 \%$

\section{E. Normalização}

0,89

\begin{tabular}{ll}
\hline Score & $\begin{array}{l}\text { Valores de Referência } \\
\text { Porcentagem do sistema viário urbano pavimentado. }\end{array}$ \\
\hline 1,00 & $100 \%$ \\
\hline 0,75 & $77,5 \%$ \\
\hline 0,50 & $55 \%$ \\
\hline 0,25 & $32,5 \%$ \\
\hline 0,00 & Até $10 \%$ \\
\hline
\end{tabular}

\subsubsection{Despesas com manutenção da infraestrutura}

\section{A. Definição}

Forma de aplicação dos recursos públicos na manutenção e conservação da infraestrutura para todos os modos de transportes.

\section{B. Fontes de Dados}

Lei de Diretrizes Orçamentárias, Secretaria Municipal de Finanças (2009).

\section{Método de Cálculo}

Identificação na Lei de Diretrizes Orçamentárias, obtida na Secretaria Municipal de Finanças, os recursos em mobilidade urbana e projetos de transporte:

Total de recursos em mobilidade urbana e projetos de transporte: $\mathrm{R} \$$ 967.173.000,00;

Investimentos em manutenção e conservação da infraestrutura de transportes (revitalização de vias, recuperação de calçadas, manutenção de vias públicas, gestão de sinalização, gerenciamento e manutenção do transporte coletivo): $\mathrm{R} \$ 866.253 .000,00$.

Calcular a porcentagem dos recursos para mobilidade e projetos de transportes investidos na manutenção e conservação de sua infraestrutura $(89,56 \%)$.

\section{Score}

1,00

\section{E. Normalização}




\section{Score Valores de Referência}

As despesas com manutenção e conservação de infraestrutura de transportes contemplaram intervenções de caráter emergencial, manutenção corretiva e preventiva das infraestruturas existentes, representando mais de $50 \%$ do total de recursos municipais investidos em sistemas de transportes e mobilidade no ano de referência

0,75

As despesas com manutenção e conservação de infraestrutura de transportes contemplaram intervenções de caráter emergencial,

0,75 manutenção corretiva e preventiva das infraestruturas existentes, representando aproximadamente $50 \%$ do total de recursos municipais investidos em sistemas de transportes e mobilidade no ano de referência

As despesas com manutenção e conservação de infraestrutura de transportes contemplaram intervenções de caráter emergencial, manutenção corretiva e preventiva das infraestruturas existentes, porém, estas despesas representaram menos de $50 \%$ do total de recursos municipais investidos em sistemas de transportes e mobilidade no ano de referência

As despesas com manutenção e conservação de infraestrutura de transportes se limitaram a intervenções de caráter emergencial

0,25 representando menos de $50 \%$ do total de recursos municipais investidos em sistemas de transportes e mobilidade no ano de referência

0,00 Não houve qualquer despesa com manutenção e conservação da infraestrutura de transportes no ano de referência no município

\subsubsection{Sinalização viária}

\section{A. Definição}

Avaliação por parte da população sobre a qualidade da sinalização viária implantada na área urbana do município.

\section{B. Fontes de Dados}

Prefeitura Municipal (Secretaria de Ação Social, Planejamento, Segurança Pública, Infraestrutura, Transportes, Mobilidade etc.), instituições de pesquisa, organizações não governamentais, estudos específicos.

\section{Método de Cálculo}

Pela insuficiência de dados, o indicador não pôde ser calculado.

\section{Score}

\section{E. Normalização}

\begin{tabular}{ll}
\hline Score & $\begin{array}{l}\text { Valores de Referência } \\
\text { A maioria da população (ou dos entrevistados) classifica a } \\
\text { sinalização viária como: }\end{array}$ \\
\hline 1,00 & $\begin{array}{l}\text { "Excelente" para os modos motorizados e não motorizados de } \\
\text { transporte }\end{array}$ \\
\hline 0,80 & "Excelente" somente para os modos motorizados de transporte \\
\hline 0,60 & $\begin{array}{l}\text { "Boa" para os modos motorizados e não motorizados de } \\
\text { transporte }\end{array}$ \\
\hline 0,40 & "Boa" somente para os modos motorizados de transporte \\
\hline 0,20 & "Ruim" somente para os modos motorizados de transporte \\
\hline 0,00 & $\begin{array}{l}\text { "Ruim" para os modos motorizados e não motorizados de } \\
\text { transporte }\end{array}$ \\
\hline
\end{tabular}




\subsubsection{Vias para transporte coletivo}

\section{A. Definição}

Porcentagem da área urbana da cidade atendida por vias exclusivas ou preferenciais para transporte coletivo por ônibus.

\section{B. Fontes de Dados}

Base georreferenciada do município fornecida pelo IPPUC (2009)

\section{Método de Cálculo}

Ferramentas auxiliares: Planilhas eletrônicas e Sistemas de Informações Geográficas.

Delimitação e cálculo da área urbana - 359,59 km² excluindo-se as áreas de APA. Identificação das vias exclusivas ou preferenciais para transporte coletivo:

Corredores exclusivos do transporte de massa;

Vias que atendem ao transporte do "Ligeirinho";

Vias com circulação de linhas alimentadoras integradas à rede troncal.

Criação de um buffer ao redor de linhas de ônibus, considerando junção das áreas sobrepostas:

Com largura de 500 metros para cada lado dos corredores e "ligeirinhos";

Com largura de 300 metros para cada lado para as linhas alimentadoras; Cálculo da área total coberta pelo buffer - $322,2 \mathrm{~km}^{2}$.

O score é obtido através do cálculo da razão entre a área total do buffer e a área urbana do município: $89,6 \%$

\section{Score}

$90 \%$

\begin{tabular}{ll}
\hline Score & $\begin{array}{l}\text { Valores de Referência } \\
\text { Porcentagem da área urbana do município é atendida por vias } \\
\text { exclusivas ou preferenciais para transporte coletivo por ônibus e } \\
\text { linhas alimentadoras integradas }\end{array}$ \\
\hline 1,00 & $100 \%$ \\
\hline 0,75 & $75 \%$ \\
\hline 0,50 & $50 \%$ \\
\hline 0,25 & $25 \%$ \\
\hline 0,00 & $0,00 \%$ \\
\hline
\end{tabular}

\section{MODOS NÃO MOTORIZADOS}

6.1 Transporte cicloviário

\subsubsection{Extensão e conectividade de ciclovias}

\section{A. Definição}

Cobertura e conectividade da rede de vias para bicicleta.

\section{B. Fontes de Dados}

Bases georreferenciadas do município fornecidas pelo IPPUC

Vias municipais;

Ciclovias. 


\section{Método de Cálculo}

Identificação da extensão do sistema viário e ciclovias:

Sistema viário: $4.485 .939 \mathrm{~m}$;

Ciclovias: $263.623,128 \mathrm{~m}$.

Calcular a razão entre a extensão total de ciclovias e a extensão total do sistema viário urbano.

\section{Score}

$5,87 \%$

\section{E. Normalização}

0,25

\section{Score Valores de Referência}

\begin{tabular}{ll}
\hline 1,00 & $\begin{array}{l}\text { Mais de } 25 \% \text { do sistema viário urbano apresenta ciclovia ou } \\
\text { ciclofaixas e a rede apresenta alta conectividade }\end{array}$ \\
\hline 0,75 & $\begin{array}{l}\text { Mais de } 25 \% \text { do sistema viário urbano apresenta ciclovia ou } \\
\text { ciclofaixas e a rede apresenta alta conectividade }\end{array}$ \\
\hline 0,50 & $\begin{array}{l}0,5<1<1 \text { Houve investimentos em infraestrutura para modos } \\
\text { não-motorizados de transporte no município no ano de referência, } \\
\text { porém, estes foram um pouco inferiores aos investimentos em } \\
\text { infraestrutura para os modos motorizados }\end{array}$ \\
\hline 0,25 & $\begin{array}{l}\text { Até } 25 \% \text { do sistema viário urbano apresenta ciclovia ou } \\
\text { ciclofaixas e a rede apresenta alta conectividade }\end{array}$ \\
\hline 0,00 & Não há no município nenhum trecho de ciclovia ou ciclofaixa \\
\hline
\end{tabular}

\subsubsection{Frota de bicicleta}

\section{A. Definição}

Número de bicicletas por 100 habitantes no município.

\section{B. Fontes de Dados}

IPPUC, pesquisa realizada em ciclovias no ano de 2008. IPARDES, número de domicílios na cidade.

\section{Método de Cálculo}

Identificação do número de bicicletas na cidade: 2,43 por domicílio. Identificação da população total do município: 1.828 .092 habitantes.

\section{Score}

72,08 bicicletas $/ 100$ habitantes

\section{E. Normalização}

1,00

\begin{tabular}{ll}
\hline Score & $\begin{array}{l}\text { Valores de Referência } \\
\text { Número de bicicletas por } 100 \text { habitantes do município }\end{array}$ \\
\hline 1,00 & 35 ou mais \\
\hline 0,75 & 30 \\
\hline 0,50 & 25 \\
\hline 0,25 & 20 \\
\hline 0,00 & Até 15 \\
\hline
\end{tabular}

\subsubsection{Estacionamento de bicicletas}

\section{A. Definição}

Porcentagem dos terminais de transporte público urbano que possuem estacionamento para bicicletas. 


\section{B. Fontes de Dados}

Instituto de Pesquisa e Planejamento Urbano de Curitiba.

\section{Método de Cálculo}

Identificação do número de terminais de transporte público urbano existentes no município:

21 terminais urbanos.

Identificação do número de terminais de transporte urbano existentes no município com infraestrutura para estacionamento de bicicletas:

Atualmente nenhum dos terminais apresenta estrutura para

estacionamento de bicicletas. Os estacionamentos que existiam nos

terminais Pinheirinho, Portão, Carmo, Hauer, Cabral, Boqueirão e CIC

foram desativados.

O score é obtido pela razão entre os terminais urbanos com bicicletário em relação ao número total de terminais.

\section{Score}

\section{E. Normalização}

\begin{tabular}{ll}
\hline Score & $\begin{array}{l}\text { Valores de Referência } \\
\text { Porcentagem dos terminais urbanos de transporte público que } \\
\text { apresentam área para estacionamento de bicicletas }\end{array}$ \\
\hline 1,00 & $100 \%$ \\
\hline 0,75 & $75 \%$ \\
\hline 0,50 & $50 \%$ \\
\hline 0,25 & $25 \%$ \\
\hline 0,00 & 0 \\
\hline
\end{tabular}

\subsection{Modos não motorizados}

\subsubsection{Vias para pedestres}

\section{A. Definição}

Cobertura e conectividade da rede de vias para pedestres.

\section{B. Fontes de Dados}

Bases georreferenciadas fornecidas pelo IPPUC:

Sistema viário;

Base do sistema viário com identificação das vias exclusivas pra pedestres (calçadões).

\section{Método de Cálculo}

Utilizando a base do sistema viário, com o auxilio de planilhas eletrônicas calculou-se as respectivas extensões:

Sistema viário: $4.485 .939 \mathrm{~m}$;

Vias exclusivas para pedestres: $3.336,68 \mathrm{~m}$. 


\section{Score}

Avaliação da conectividade da rede de ciclovias com base: na manutenção das características físicas e operacionais da ciclovia; ausência de barreiras físicas que impeçam ou restrinjam os deslocamentos e continuidade - baixa conectividade:

0,074

\section{E. Normalização}

0,25

\section{Score Valores de Referência}

\begin{tabular}{ll}
\hline 1,00 & $\begin{array}{l}\text { Mais de 25\% do sistema viário urbano é composto por vias } \\
\text { especiais ou preferenciais para pedestres e a rede apresenta alta } \\
\text { conectividade }\end{array}$ \\
\hline 0,75 & $\begin{array}{l}\text { Mais de } 25 \% \text { do sistema viário urbano é composto por vias } \\
\text { especiais ou preferenciais para pedestres, porém, a rede } \\
\text { apresenta baixa conectividade }\end{array}$ \\
\hline 0,50 & $\begin{array}{l}\text { Até } 25 \% \text { do sistema viário urbano é composto por vias especiais } \\
\text { ou preferenciais para pedestres e a rede apresenta alta } \\
\text { conectividade }\end{array}$ \\
\hline 0,25 & $\begin{array}{l}\text { Até } 25 \% \text { do sistema viário urbano é composto por vias especiais } \\
\text { ou preferenciais para pedestres, porém, a rede apresenta baixa } \\
\text { conectividade }\end{array}$ \\
\hline 0,00 & Não há no município vias especiais ou preferenciais para pedestres \\
\hline
\end{tabular}

\subsubsection{Vias com calçadas}

\section{A. Definição}

Extensão de vias com calçadas em ambos os lados, com largura superior a 1,20 metros, em relação à extensão total da rede viária principal.

\section{B. Fontes de Dados}

Base georreferenciada do município.

\section{Método de Cálculo}

Identificação das extensões do sistema viário e das calçadas.

Sistema viário: $826.293 \mathrm{~m}$

Calçadas: $826.293 \mathrm{~m}$

O quociente entre a extensão total da rede viária principal e a extensão de vias com calçadas em ambos os lados, com largura superior a 1,20 metros e a extensão total da extensão total percorrida fornece o score.

\section{Score}

$100 \%$

\section{E. Normalização}

1,00

\begin{tabular}{ll}
\hline Score & $\begin{array}{l}\text { Valores de Referência } \\
\text { Porcentagem da rede viária principal que apresenta calçadas em } \\
\text { ambos os lados e com largura igual ou superior a 1,20 metros }\end{array}$ \\
\hline 1,00 & $100 \%$ \\
\hline 0,75 & $77,5 \%$ \\
\hline 0,50 & $55 \%$ \\
\hline 0,25 & $32,5 \%$ \\
\hline 0,00 & Até $10 \%$ \\
\hline
\end{tabular}




\subsubsection{Distância de viagem}

\section{A. Definição}

Distância média de viagens feitas na área urbana ou metropolitana, para todos os modos, em um único sentido, por motivo trabalho ou estudo.

\section{B. Fontes de Dados}

Dados indisponíveis.

\section{Método de Cálculo}

Cálculo não realizado pela indisponibilidade de dados.

\section{Score}

\section{E. Normalização}

\begin{tabular}{ll}
\hline Score & $\begin{array}{l}\text { Valores de Referência } \\
\text { Distância média das viagens urbanas e metropolitanas, para todos } \\
\text { os modos, em um único sentido, por motivo trabalho ou estudo }\end{array}$ \\
\hline 1,00 & Igual ou inferior a $2 \mathrm{~km}$ \\
\hline 0,75 & $4 \mathrm{~km}$ \\
\hline 0,50 & $6 \mathrm{~km}$ \\
\hline 0,25 & $8 \mathrm{~km}$ \\
\hline 0,00 & Maior ou igual a $10 \mathrm{~km}$ \\
\hline
\end{tabular}

\section{A. Definição}

Tempo médio de viagens feitas na área urbana ou metropolitana, para todos os modos, em um único sentido, por motivo trabalho ou estudo

\section{B. Fontes de Dados}

Dados indisponíveis.

\section{Método de Cálculo}

Cálculo não realizado pela indisponibilidade de dados.

D. Score

\section{E. Normalização}

\begin{tabular}{ll}
\hline Score & $\begin{array}{l}\text { Valores de Referência } \\
\text { Tempo médio de viagem para deslocamentos urbanos e } \\
\text { metropolitanos, por motivo trabalho e estudo, para todos os } \\
\text { modos de transporte }\end{array}$ \\
\hline 1,00 & Igual ou inferior a $20 \mathrm{~min}$ \\
\hline 0,75 & $30 \mathrm{~min}$ \\
\hline 0,50 & $40 \mathrm{~min}$ \\
\hline 0,25 & $50 \mathrm{~min}$ \\
\hline 0,00 & 60 min ou mais \\
\hline
\end{tabular}


6.3.3 Número de viagens

\section{A. Definição}

Número médio de viagens diárias por habitante em área urbana ou metropolitana, considerando todos os modos de transporte.

\section{B. Fontes de Dados}

Dados indisponíveis.

\section{Método de Cálculo}

Cálculo não realizado pela indisponibilidade de dados.

\section{Score}

\section{E. Normalização}

\begin{tabular}{ll}
\hline Score & $\begin{array}{l}\text { Valores de Referência } \\
\text { Número médio de viagens diárias por habitante }\end{array}$ \\
\hline 1,00 & 2 ou mais \\
\hline 0,75 & 1,5 \\
\hline 0,50 & 1,0 \\
\hline 0,25 & 0,5 \\
\hline 0,00 & Inferior a 0,5 \\
\hline
\end{tabular}

\subsubsection{Ações para reduções do tráfego motorizado}

\section{A. Definição}

Políticas, estratégias ou ações empreendidas pelo município com objetivo de reduzir o tráfego motorizado.

\section{B. Fontes de Dados}

Departamento de Comunicação Social da URBS.

\section{Método de Cálculo}

Levantamento e análise dos dispositivos desenvolvidos e implantados no município no ano de referência, relacionados à redução do tráfego motorizado: Campanhas educativas em escolas, universidades e empresas (carona solidária), vagas disponíveis para veículos com mais de 3 pessoas, novas faixas exclusivas, transporte de funcionários em ônibus fretados, EDUCATRAN (crianças aprendem a ser pedestres), terceira idade (segurança e percepção de trânsito)

\section{Score}

Foram desenvolvidas e implantadas apenas campanhas educativas.

\section{E. Normalização}




\begin{tabular}{|c|c|}
\hline \multirow{2}{*}{ Score } & Valores de Referência \\
\hline & Foram implantados no município: \\
\hline 1,00 & $\begin{array}{l}\text { Campanha educativa, rodízio veicular, delimitação de áreas com } \\
\text { restrição para circulação de veículos e pedágio urbano }\end{array}$ \\
\hline 0,75 & $\begin{array}{l}\text { Campanha educativa, rodízio veicular e delimitação de áreas com } \\
\text { restrição para circulação de veículos }\end{array}$ \\
\hline 0,50 & Campanha educativa e rodízio veicular \\
\hline 0,25 & Apenas campanha educativa \\
\hline 0,00 & $\begin{array}{l}\text { Não foi desenvolvido ou implantado nenhum mecanismo visando } \\
\text { à redução do tráfego motorizado no município no ano de } \\
\text { referência }\end{array}$ \\
\hline
\end{tabular}

\section{PLANEJAMENTO INTEGRADO}

\subsection{Capacitação de gestores}

\subsubsection{Nível de formação de técnicos e gestores}

\section{A. Definição}

Porcentagem de técnicos e gestores de órgãos de planejamento urbano, transportes e mobilidade com qualificação superior, do total de trabalhadores destes órgãos no ano de referência.

\section{B. Fontes de Dados}

Informações obtidas através de entrevistas com funcionários de diversas secretarias da prefeitura municipal.

\section{Método de Cálculo}

O indicador em questão foi estimado pelas características observadas nos órgãos municipais consultados.

\section{Score}

Mais de $25 \%$

\section{E. Normalização}

1,00

\begin{tabular}{ll}
\hline Score & $\begin{array}{l}\text { Valores de Referência } \\
\text { Porcentagem dos técnicos e gestores de órgãos de planejamento } \\
\text { urbano, transportes e mobilidade, no ano de referência, que } \\
\text { possuem qualificação superior }\end{array}$ \\
\hline 1,00 & $25 \%$ ou mais \\
\hline 0,75 & $20 \%$ \\
\hline 0,50 & $15 \%$ \\
\hline 0,25 & $10 \%$ \\
\hline 0,00 & Até $5 \%$ \\
\hline
\end{tabular}

\subsubsection{Capacitação de técnicos e gestores}

\section{A. Definição}

Número de horas de treinamento e capacitação oferecidas por técnico e gestor das áreas de planejamento urbano, transportes e mobilidade durante o ano de referência. 


\section{B. Fontes de Dados}

Informações obtidas através de entrevistas com funcionários de diversas secretarias da prefeitura municipal.

\section{Método de Cálculo}

O indicador em questão foi estimado pelas características observadas nos órgãos municipais consultados.

\section{Score}

40 horas ou mais

\section{E. Normalização}

0,25

\begin{tabular}{ll}
\hline Score & $\begin{array}{l}\text { Valores de Referência } \\
\text { Horas/funcionário/ano de cursos e treinamentos oferecidos a } \\
\text { técnicos e gestores das áreas de planejamento urbano, } \\
\text { transportes e mobilidade no ano de referência }\end{array}$ \\
\hline 1,00 & 40 horas ou mais \\
\hline 0,75 & 32 horas \\
\hline 0,50 & 24 horas \\
\hline 0,25 & 16 horas \\
\hline 0,00 & 8 horas ou menos \\
\hline
\end{tabular}

7.2 Áreas centrais e de interesse histórico

\subsubsection{Vitalidade do centro}

\section{A. Definição}

Medida da vitalidade do centro da cidade em dois momentos distintos, baseada no número de residentes e no número de empregos nos setores de comércio e serviços localizados na área.

\section{B. Fontes de Dados}

Instituto de Pesquisa e Planejamento Urbano de Curitiba (IPPUC), site oficial (2009).

\section{Método de Cálculo}

Adaptação do índice para o uso dos dados de número de estabelecimentos no lugar do número de empregos na região central.

Identificação dos usos no bairro Centro para o ano de 2006:

Domicílios: 15.076;

Indústrias: 882;

Comércios: 8.320 ;

Serviços: 10.572;

Outros: 97

Identificação dos usos no bairro Centro para o ano de 2007:

Domicílios: 15.149;

Indústrias: 914 ;

Comércios: 8.565;

Serviços: 11.033;

Outros: 101.

Para o cálculo do score foi utilizada a seguinte fórmula: 
Onde:

I = medida da vitalidade da área central;

$\mathrm{D}$ = número de domicílios na área central da cidade para o ano de referência;

Do = número de domicílios na área central da cidade para o ano-base;

$\mathrm{E}=$ número de empregos nos segmentos de comércio e serviços privados na área central da cidade para o ano de referência;

Eo = número de empregos nos segmentos de comércio e serviços privados na área central da cidade para o ano-base.

\section{Score}

1,02

\section{E. Normalização}

0,51

\begin{tabular}{ll}
\hline Score & Valores de Referência \\
\hline 1,00 & $\begin{array}{l}\text { I }>1,50 \text { O centro apresenta forte tendência de crescimento do número } \\
\text { de domicílios particulares e empregos nos setores de comércio e } \\
\text { serviços, e forte equilibrio entre as atividades diurnas e noturnas }\end{array}$ \\
\hline 0,75 & $\begin{array}{l}\text { I }=1,50 \text { O centro apresenta tendência de crescimento do número } \\
\text { de domicílios particulares e empregos nos setores de comércio e } \\
\text { serviços, e equilibrio entre as atividades diurnas e noturnas }\end{array}$ \\
\hline 0,50 & $\begin{array}{l}\text { I= } 1,00 \text { O centro apresenta tendência de estabilidade com manutenção } \\
\text { do número de domicílios particulares e empregos nos setores de } \\
\text { comércio e serviços, e equilíbrio entre as atividades diurnas e noturnas }\end{array}$ \\
\hline $\begin{array}{l}\text { I = 0,50 O centro da cidade apresenta tendência de esvaziamento, } \\
\text { com declínio do número de domicílios particulares e empregos } \\
\text { nos setores de comércio e serviços, e desequilíbrio entre as } \\
\text { atividades diurnas e noturnas }\end{array}$ \\
\hline $\begin{array}{l}\text { I<0,50 O centro da cidade apresenta forte tendência de } \\
\text { esvaziamento, com declínio acentuado do número de domicílios } \\
\text { particulares e empregos nos setores de comércio e serviços, e } \\
\text { forte desequilíbrio entre as atividades diurnas e noturnas }\end{array}$ \\
\hline
\end{tabular}

\subsection{Integração regional}

\subsubsection{Consórcios intermunicipais}

\section{A. Definição}

Existência de consórcios públicos intermunicipais para provisão de infraestrutura e serviços de transportes urbano e metropolitano.

\section{B. Fontes de Dados}

Informações fornecidas pela URBS (2009).

\section{Método de Cálculo}

Verificação da existência de consórcios públicos intermunicipais para a provisão de infraestrutura e serviços de transporte:

Não existem consórcios firmados no município de acordo com a lei que os regulamenta, porém existem diversos acordos políticos para provisão de infra-estrutura de transporte de passageiros.

\section{Score}

Aquisição de máquinas e equipamentos, execução de obras de manutenção, conservação e construção de infraestrutura e/ou prestação de serviços de transporte urbano e metropolitano.

\section{E. Normalização}




\begin{tabular}{ll}
\hline Score & $\begin{array}{l}\text { Valores de Referência } \\
\text { Foi firmado ou encontra-se em vigor no ano de referência } \\
\text { consórcio intermunicipal para: }\end{array}$ \\
\hline 1,00 & $\begin{array}{l}\text { Aquisição de máquinas e equipamentos, execução de obras de } \\
\text { manutenção, conservação e construção de infraestrutura e/ou } \\
\text { prestação de serviços de transporte urbano e metropolitano }\end{array}$ \\
\hline 0,75 & $\begin{array}{l}\text { Aquisição de máquinas e equipamentos e execução de obras de } \\
\text { manutenção, conservação e construção de infraestrutura de } \\
\text { transportes }\end{array}$ \\
\hline 0,50 & $\begin{array}{l}\text { Aquisição de máquinas e equipamentos e execução de obras de } \\
\text { manutenção e conservação de infraestrutura de transportes }\end{array}$ \\
\hline 0,25 & $\begin{array}{l}\text { Aquisição de máquinas e equipamentos para provisão de } \\
\text { infraestrutura de transportes }\end{array}$ \\
\hline 0,00 & $\begin{array}{l}\text { Não foi firmado ou encontra-se em vigor nenhum consórcio } \\
\text { intermunicipal para provisão de infraestrutura e prestação de }\end{array}$ \\
\hline
\end{tabular}

\subsection{Transparência do processo de planejamento}

\subsubsection{Transparência e responsabilidade}

\section{A. Definição}

Existência de publicação formal e periódica por parte da administração municipal sobre assuntos relacionados à infraestrutura, serviços, planos e projetos de transportes e mobilidade urbana.

\section{B. Fontes de Dados}

Informações disponíveis no endereço oficial na internet da Prefeitura Municipal de Curitiba (2008), Secretaria de Obras, Secretaria de Finanças. Secretaria de Comunicação Social.

\section{Método de Cálculo}

Licitações web (contratos e licitações para execução de obras de infraestrutura e prestação de serviços de transporte público), Secretaria de Obras (estágio de desenvolvimento de planos e projetos, Secretaria de Finanças (aplicação e fonte de recursos), Secretaria de Comunicação Social (impactos sociais, econômicos e ambientais de planos e projetos de transportes e mobilidade urbana).

Verificação das informações disponíveis no endereço oficial da Prefeitura Municipal de Curitiba na Internet referente à publicação formal e periódica sobre assuntos relacionados à infraestrutura, serviços, planos e projetos de transportes e mobilidade urbana:

Licitações web (contratos e licitações para execução de obras de infraestrutura e prestação de serviços de transporte público);

Secretaria de Obras (estágio de desenvolvimento de planos e projetos; Secretaria de Finanças (aplicação e fonte de recursos);

Secretaria de Comunicação Social (impactos sociais, econômicos e ambientais de planos e projetos de transportes e mobilidade urbana); Diário Oficial do Município (informações disponibilizadas no endereço oficial na Internet). Constam informações referentes a investimentos em sistema viário.

Identificação do score com base no levantamento efetuado.

\section{Score}

Contratos e licitações para execução de obras de infraestrutura e prestação de serviços de transporte público, estágio de desenvolvimento de planos e projetos, aplicação e fonte de recursos, e impactos sociais, econômicos e ambientais de planos e projetos de transportes e mobilidade urbana 


\section{E. Normalização}

1,00

\begin{tabular}{ll}
\hline Score & Valores de Referência \\
& Existência de publicação formal e periódica sobre: \\
\hline 1,00 & $\begin{array}{l}\text { Contratos e licitações para execução de obras de infraestrutura e } \\
\text { prestação de serviços de transporte público, estágio de } \\
\text { desenvolvimento de planos e projetos, aplicação e fonte de } \\
\text { recursos, e impactos sociais, econômicos e ambientais de planos } \\
\text { e projetos de transportes e mobilidade urbana }\end{array}$ \\
\hline 0,75 & $\begin{array}{l}\text { Contratos e licitações para execução de obras de infraestrutura e } \\
\text { prestação de serviços de transporte público, estágio de } \\
\text { desenvolvimento de planos e projetos e aplicação e fonte de } \\
\text { recursos para planos e projetos de transportes e mobilidade } \\
\text { urbana }\end{array}$ \\
\hline 0,50 & $\begin{array}{l}\text { Contratos e licitações para execução de obras de infraestrutura e } \\
\text { prestação de serviços de transporte público, e estágio de } \\
\text { desenvolvimento de planos e projetos de transportes e mobilidade } \\
\text { urbana }\end{array}$ \\
\hline 0,25 & $\begin{array}{l}\text { Contratos e licitações para execução de obras de infraestrutura e } \\
\text { prestação de serviços de transporte públicos }\end{array}$ \\
\hline 0,00 & $\begin{array}{l}\text { Não há publicação formal e periódica sobre assuntos relacionados } \\
\text { à infraestrutura, serviços, planos e projetos de transportes e } \\
\text { mobilidade urbana }\end{array}$ \\
\hline
\end{tabular}

\section{Método de Cálculo}

Cálculo da área urbana - $430 \mathrm{~km}^{2}$.

Cálculo da área dos lotes vagos - 58,42 km².

Cálculo da razão entre a área total de vazios e área urbana.

\section{Score}

$13,58 \%$

\section{E. Normalização}

0,91

\begin{tabular}{ll}
\hline Score & $\begin{array}{l}\text { Valores de Referência } \\
\text { Porcentagem da área urbana do município vazia ou desocupada. }\end{array}$ \\
\hline 1,00 & Até $10 \%$ \\
\hline 0,75 & $20 \%$ \\
\hline 0,50 & $30 \%$ \\
\hline 0,25 & $40 \%$ \\
\hline 0,00 & $50 \%$ ou mais \\
\hline
\end{tabular}

\subsection{Planejamento e controle do uso e ocupação do solo}

\subsubsection{Vazios urbanos}

\section{A. Definição}

Porcentagem de áreas que se encontram vazias ou desocupadas na área urbana.

\section{B. Fontes de Dados}

Informações fornecidas pelo IPPUC (2009). 


\section{A. Definição}

Razão entre a área de novos projetos (para diferentes usos) previstos ou em fase de implantação em regiões dotadas de infraestrutura e serviços de transportes, e a área de novos projetos em regiões ainda não desenvolvidas e sem infraestrutura de transportes.

\section{B. Fontes de Dados}

Base georreferenciada dos lotes vagos e glebas vagas no município fornecida pelo IPPUC (2009).

Base georreferenciada de linhas de ônibus, fornecida pelo IPPUC (2009).

\section{Método de Cálculo}

Identificação da área total de lotes e glebas vazios na cidade: $58,42 \mathrm{~km}^{2}$ Criação de um buffer ao redor das linhas de transporte público.

Cruzamento da área do buffer com a dos lotes e glebas vazias no município:

Cobertura do buffer nos lotes e glebas: $38,08 \mathrm{~km}^{2}$;

Lotes e glebas não cobertos pelo buffer: $20,34 \mathrm{~km}^{2}$.

Cálculo da razão entre a área total de novos projetos em áreas dotadas de infraestrutura de transportes e a área total de novos projetos em áreas sem infraestrutura de transportes.

\section{Score}

1,87

\section{E. Normalização}

\begin{tabular}{ll}
\hline Score & $\begin{array}{l}\text { Valores de Referência } \\
\text { Razão entre a área total de novos projetos em áreas dotadas de } \\
\text { infraestrutura de transportes e a área total de novos projetos em } \\
\text { áreas sem infraestrutura de transportes }\end{array}$ \\
\hline 1,00 & Igual ou maior que 2 \\
\hline 0,75 & 1,5 \\
\hline 0,50 & 1 \\
\hline 0,25 & 0,5 \\
\hline 0,00 & 0 \\
\hline
\end{tabular}

\subsubsection{Densidade populacional urbana}

\section{A. Definição}

Razão entre o número total de habitantes da área urbana e a área total urbanizada do município.

\section{B. Fontes de Dados}

Base georreferenciada do município fornecida pelo IPPUC (2009). Base georreferenciada de Setores Censitários do IBGE (2000).

Estimativa de habitantes para o ano de 2009, IPARDES (2009).

\section{Método de Cálculo}

Ferramentas auxiliares: planilhas eletrônicas.

Área urbana: $430,9 \mathrm{~km}^{2}$, porém foi desconsidera as áreas de APA dentro do perímetro, resultando numa área de $359,59 \mathrm{~km}^{2}$.

População urbana do município segundo estimativas do IPARDES (2000) 1.828.092 habitantes.

Cálculo da razão entre a população urbana total e a área urbanizada. 
D. Score

5.084 habitantes $/ \mathrm{km}^{2}$

\section{E. Normalização}

0,00

\begin{tabular}{|c|c|}
\hline \multirow{2}{*}{ Score } & Valores de Referência \\
\hline & Densidade populacional urbana \\
\hline 1,00 & 45.000 habitantes $/ \mathrm{km} 2$ ou 450 habitantes/ha \\
\hline 0,75 & 35.000 habitantes $/ \mathrm{km} 2$ ou 350 habitantes/ha \\
\hline 0,50 & 25.000 habitantes $/ \mathrm{km} 2$ ou 250 habitantes/ha \\
\hline 0,25 & 15.000 habitantes/km2 ou 150 habitantes/ha \\
\hline 0,00 & $\begin{array}{l}\text { Até } 5.000 \text { habitantes } / \mathrm{km} 2 \text { ou } 50 \text { habitantes } / \text { ha ou superior a } 45.00 \\
\text { habitantes/km2 ou } 450 \text { habitantes/ha }\end{array}$ \\
\hline
\end{tabular}

\subsection{4 Índice de uso misto}

\section{A. Definição}

Porcentagem da área urbana destinada ao uso misto do solo, conforme definido em legislação municipal.

\section{B. Fontes de Dados}

Lei Municipal de Uso e Ocupação do Solo (Lei Municipal n 9.800/00).

\section{Método de Cálculo}

Análise do Plano Diretor Municipal para identificação das zonas e setores onde é verificado o uso misto do solo considerando os usos permitidos, tolerados e permissíveis:
Zona Central (ZC):

Zona Residencial de Ocupação Controlada (ZR-OC);

Zona Residencial 1 (ZR-1);

Zona Residencial 2 (ZR-2);

Zona Residencial 3 (ZR-3);

Zona Residencial 4 (ZR-4);

Zona Residencial Batel (ZR-B);

Zona Residencial Alto da Glória (ZR-AG);

Zona Residencial Mercês (ZR-M);

Zona Residencial Santa Felicidade (ZR-SF);

Zona Residencial Umbará (ZR-U);

Zona Residencial Passaúna (ZR-P);

Zona de Serviços 1 (ZS-1);

Zona de Serviços 2 (ZS-2);

Zona Especial de Serviços (ZES);

Zona de Transição da Av. Mal Floriano Peixoto (ZT-MF);

Zona de Transição Nova Curitiba (ZT-NC);

Zona de Transição BR-116 (ZT-BR-116);

Zona Industrial (ZI);

Zona de Uso Misto (ZUM);

Zona Especial Educacional (ZE-E);

Zona Especial Desportiva (ZE-D);

Zona Especial Militar (ZE-M);

Zona de Contenção (Z-COM);

Setor Especial Estrutural (SE);

Setor Especial da BR-116 (SE-BR-116);

Setor Especial da Av. Mal Floriano Peixoto (SE-MF);

Setor Especial da Av. Comendador Franco (SE-CF);

Setor Especial da Av. Pres. Wenceslau Braz (SE-WB); 
Setor Especial da Av. Pres. Affonso Camargo (SE-AC);

Setor Especial da Rua Engenheiro Costa Barros (SE-CB);

Setores Especiais Conectores (CONEC);

Setor Especial Centro Cívico (SE-CC);

Setor Especial Preferencial de Pedestres (SE-PP);

Setor Especial Comercial - Santa Felicidade (SC-SF);

Setor Especial Nova Curitiba (SE-NC);

Setor Especial Institucional (SEI);

Setor Especial de Habitação de Interesse Especial (SEHIS);

Setor Especial Linhão do Emprego (SE-LE);

Cálculo da área total onde o uso misto é permitido/incentivado - $430 \mathrm{~km}^{2}$.

Cálculo da área urbana - $430 \mathrm{~km}^{2}$.

Cálculo do quociente entre a área total onde é permitido/tolerado/permissivo o uso misto e a área urbana total.

\section{Score}

$100 \%$

\section{E. Normalização}

1,00

\begin{tabular}{ll}
\hline Score & $\begin{array}{l}\text { Valores de Referência } \\
\text { Porcentagem da área urbana do município onde é } \\
\text { permitido/incentivado o uso misto do solo com atividades } \\
\text { compatíveis entre si e com o uso residencial }\end{array}$ \\
\hline 1,00 & Mais de 75\% \\
\hline 0,75 & $75 \%$ \\
\hline 0,50 & $50 \%$ \\
\hline 0,25 & $25 \%$ \\
\hline 0,00 & $\begin{array}{l}\text { A legislação urbanística municipal não permite o uso misto do } \\
\text { solo, determinando zonas de uso exclusivamente residencial, } \\
\text { comercial, industrial ou institucional, resultando em intensa } \\
\text { setorização da área urbana }\end{array}$ \\
\hline
\end{tabular}

\subsubsection{Ocupação irregulares}

\section{A. Definição}

Porcentagem da área urbana constituída por assentamentos informais ou irregulares.

\section{B. Fontes de Dados}

Base georreferenciada com a localização das glebas e lotes com ocupações irregulares, fornecida pelo IPPUC (2005).

\section{Método de Cálculo}

Cálculo da área total do município: $430 \mathrm{~km}^{2}$

Cálculo da área total de ocupações irregulares: 11,94km².

\section{Score}




\section{E. Normalização}

1,00

\begin{tabular}{ll}
\hline Score & $\begin{array}{l}\text { Valores de Referência } \\
\text { Porcentagem da área urbana constituída de ocupações irregulares } \\
\text { e assentamentos informais }\end{array}$ \\
\hline 1,00 & Até $5 \%$ \\
\hline 0,75 & $10 \%$ \\
\hline 0,50 & $15 \%$ \\
\hline 0,25 & $20 \%$ \\
\hline 0,00 & Mais de $20 \%$ \\
\hline
\end{tabular}

\subsection{Planejamento estratégico e integrado}

\subsubsection{Planejamento urbano, ambiental e de transportes integrado}

\section{A. Definição}

Existência de cooperação formalizada entre os órgãos responsáveis pelo planejamento e gestão de transportes, planejamento urbano e meio ambiente no desenvolvimento de estratégias integradas para a melhoria das condições de mobilidade urbana.

\section{B. Fontes de Dados}

Informações fornecidas pela URBS e IPPUC (2009).

\section{Método de Cálculo}

Existe a cooperação entre órgãos municipais, sempre mediado pelo IPPUC, órgão responsável pelo planejamento do município.

\section{Score}

Órgãos gestores de transportes, meio ambiente e planejamento urbano no desenvolvimento de planos e programas de abrangência municipal para melhoria das condições de mobilidade urbana, inclusive com a instituição de um órgão intersecretarial permanente.

\section{E. Normalização}

1,00

\begin{tabular}{ll}
\hline Score & Valores de Referência \\
& Há cooperação formal entre: \\
\hline 1,00 & $\begin{array}{l}\text { Órgãos gestores de transportes, meio ambiente e planejamento } \\
\text { urbano no desenvolvimento de planos e programas de } \\
\text { abrangência municipal para melhoria das condições de mobilidade } \\
\text { urbana, inclusive com a instituição de um órgão intersecretarial } \\
\text { permanente }\end{array}$ \\
\hline $0,75 \quad \begin{array}{l}\text { Órgãos gestores de transportes, meio ambiente e planejamento } \\
\text { urbano no desenvolvimento de planos e programas de } \\
\text { abrangência municipal para melhoria das condições de mobilidade } \\
\text { urbana }\end{array}$ \\
\hline $0,50 \quad \begin{array}{l}\text { Órgãos gestores de transportes, meio ambiente e planejamento } \\
\text { urbano no desenvolvimento de ações pontuais para melhoria das } \\
\text { condições de mobilidade urbana }\end{array}$ \\
\hline $\begin{array}{l}\text { Órgãos gestores de transportes, meio ambiente e planejamento } \\
\text { urbano no desenvolvimento de ações pontuais para melhoria das } \\
\text { condições de mobilidade urbana }\end{array}$ \\
\hline $\begin{array}{l}\text { Não há qualquer forma de cooperação entre os órgãos gestores } \\
\text { de transportes, meio ambiente e planejamento urbano no } \\
\text { desenvolvimento de planos e ações para melhoria das condições } \\
\text { de mobilidade urbana }\end{array}$ \\
\hline
\end{tabular}




\subsubsection{Efetivação e continuidade das ações}

\section{A. Definição}

Programas e projetos de transportes e mobilidade urbana efetivados pela administração municipal no ano de referência e continuidade das ações implementadas.

\section{B. Fontes de Dados}

Ações, planos, programas e projetos relacionados à provisão, ampliação, melhoria e manutenção da infraestrutura, sistemas de transportes e mobilidade em todas as modalidades, propostos e efetivados durante a última gestão, respeitando os prazos e horizontes definidos em sua fase de planejamento.

\section{Método de Cálculo}

As ações efetivadas na gestão anterior foram:

Sinalização de $100 \%$ dos radares;

Implantação de 94 novos semáforos para pedestres;

Implantação da Linha Verde ( $1^{\mathrm{a}}$.etapa);

Renovação de 42 \% da frota de ônibus;

Implantação da Tarifa Domingueira aumentando o número de

passageiros;

Ampliação de 7,3 \% no número de passageiros pagantes nos dias úteis.

As ações propostas e já realizadas ou em processo de realização são:

Continuidade na implantação da Linha Verde (1ª . etapa);

Revitalização e Reconstrução de Terminais;

Continuidade ao Programa Caminhos da Cidade;

Continuidade da renovação da frota
As ações da gestão anterior mantém uma intensa continuidade na gestão atual. Isso se deve ao fato de não ter havido mudança no quadro municipal, promovida pela reeleição do atual prefeito.

\section{Score}

Grande parte das ações para transportes e mobilidade urbana previstas pela atual gestão foram efetivadas, tendo sido dada continuidade às mesmas mesmo após mudanças no quadro da administração municipal.

\section{E. Normalização}

1,00

\begin{tabular}{ll}
\hline Score & Valores de Referência \\
\hline 1,00 & $\begin{array}{l}\text { Grande parte das ações para transportes e mobilidade urbana } \\
\text { previstas pela atual gestão foram efetivadas, tendo sido dada } \\
\text { continuidade às mesmas mesmo após mudanças no quadro da } \\
\text { administração municipal }\end{array}$ \\
\hline 0,75 & $\begin{array}{l}\text { Algumas ações para transportes e mobilidade urbana previstas } \\
\text { pela atual gestão foram efetivadas, tendo sido dada continuidade } \\
\text { às mesmas mesmo após mudanças no quadro da administração } \\
\text { municipal }\end{array}$ \\
\hline 0,50 & $\begin{array}{l}\text { Grande parte das ações para transportes e mobilidade urbana } \\
\text { previstas pela atual gestão foi efetivada, no entanto, grande parte } \\
\text { foi abandonada em função de mudanças no quadro da } \\
\text { administração municipal }\end{array}$ \\
\hline 0,25 & $\begin{array}{l}\text { Algumas ações para transportes e mobilidade urbana previstas } \\
\text { pela atual gestão foram efetivadas, no entanto, grande parte foi } \\
\text { abandonada em função de mudanças no quadro da administração } \\
\text { municipal }\end{array}$ \\
\hline 0,00 & $\begin{array}{l}\text { Nenhuma ação para transportes e mobilidade urbana prevista pela } \\
\text { atual gestão não foi efetivada }\end{array}$ \\
\hline
\end{tabular}


7.7 Planejamento da infraestrutura urbana e equipamentos urbanos

\subsubsection{Parques e áreas verdes}

\section{A. Definição}

Área urbana com cobertura vegetal (parques, jardins, áreas verdes) por habitante.

\section{B. Fontes de Dados}

Base georreferenciada do município fornecida pelo IPPUC (2009).

Base georreferenciada de Setores Censitários do IBGE (2000).

\section{Método de Cálculo}

Ferramentas auxiliares: Planilhas eletrônicas e Sistemas de Informações Geográficas

Cálculo da área verde total - 15.277.849 $\mathrm{m}^{2}$.

População urbana do município segundo estimativas do IPARDES (2009) 1.828.092 habitantes.

Cálculo da razão entre a área total de cobertura vegetal e a população urbana para obtenção do score.

\section{Score}

$8,36 \mathrm{~m}^{2} /$ habitante

\section{E. Normalização}

0,17

\begin{tabular}{ll}
\hline Score & $\begin{array}{l}\text { Valores de Referência } \\
\text { Área verde por habitante }\end{array}$ \\
\hline 1,00 & Igual ou superior a $25 \mathrm{~m}^{2}$ por habitante \\
\hline 0,75 & $20 \mathrm{~m}^{2}$ por habitante \\
\hline 0,50 & $15 \mathrm{~m}^{2}$ por habitante \\
\hline 0,25 & $10 \mathrm{~m}^{2}$ por habitante \\
\hline 0,00 & Igual ou inferior a $5 \mathrm{~m}^{2}$ por habitante \\
\hline
\end{tabular}

\subsubsection{Equipamentos urbanos (escolas)}

\section{A. Definição}

Número de escolas em nível de educação infantil e ensino fundamental, públicas e particulares, por 1000 habitantes.

\section{B. Fontes de Dados}

Base georreferenciada do município fornecida pelo IPPUC (2009).

Base georreferenciada dos equipamentos de educação fornecida pelo IPPUC (2009).

Estimativa da população total do município IPARDES (2009).

\section{Método de Cálculo}

Ferramentas auxiliares: Planilhas eletrônicas e Sistemas de Informações Geográficas.

Separação dos equipamentos de interesse: escolas de educação infantil e ensino fundamental, públicas ou particulares:

Escolas Municipais: 173;

Escolas particulares: 323

Escolas estaduais: 150; 
Total: 646 escolas.

População urbana do município segundo estimativas do IPARDES (2009) 1.828.092 habitantes.

O indicador é obtido através da equação:

$$
\mathrm{I}=E 1000 / P
$$

Onde:

$E$ = número de escolas públicas e particulares de ensino pré-escolar infantil, fundamental e médio no município;

$\mathrm{P}=$ população total do município no ano de referência.

\section{Score}

0,35 escolas $/ 1.000$ habitantes

\section{E. Normalização}

0,10

\begin{tabular}{ll}
\hline Score & $\begin{array}{l}\text { Valores de Referência } \\
\text { Número de escolas por } 1000 \text { habitantes no município }\end{array}$ \\
\hline 1,00 & Igual ou superior a 1,25 \\
\hline 0,75 & 1,00 \\
\hline 0,50 & 0,75 \\
\hline 0,25 & 0,50 \\
\hline 0,00 & Igual ou inferior a 0,25 \\
\hline
\end{tabular}

\subsubsection{Equipamentos urbanos (postos de saúde)}

\section{A. Definição}

Número de equipamentos de saúde ou unidades de atendimento médico primário (postos de saúde) por 100.000 habitantes.

\section{B. Fontes de Dados}

Base georreferenciada de dados equipamentos de saúde fornecida pelo IPPUC; Estimativa da população total do município IPARDES (2009).

\section{Método de Cálculo}

Ferramentas auxiliares: Planilhas eletrônicas.

Levantamento do número de equipamentos de saúde em nível primário - 128 unidades de saúde.

População urbana do município segundo estimativas do IPARDES (2009) 1.828.092 habitantes.

O indicador é obtido através da equação:

$$
\mathrm{I}=P / 100.000 \mathrm{~S}
$$

Onde:

$S$ = número de equipamentos de saúde (postos de saúde) no município;

$\mathrm{P}=$ população total do município no ano de referência.

\section{Score}

7 postos de saúde/100.000 habitantes

\section{E. Normalização}




\begin{tabular}{ll}
\hline Score & $\begin{array}{l}\text { Valores de Referência } \\
\text { Número de postos de saúde por } 100.000 \text { habitantes no município }\end{array}$ \\
\hline 1,00 & 50 ou mais \\
\hline 0,75 & 40 \\
\hline 0,50 & 30 \\
\hline 0,25 & 20 \\
\hline 0,00 & Até 10 \\
\hline
\end{tabular}

\subsection{Plano Diretor e legislação urbanística}

\subsubsection{Plano Diretor}

\section{A. Definição}

Existência e ano de elaboração/atualização do Plano Diretor Municipal.

\section{B. Fontes de Dados}

Legislação Municipal.

\section{Método de Cálculo}

Consulta a legislação municipal:

Plano Diretor Municipal - Lei Municipal no 11.266/04.

\section{Score}

O município dispõe de Plano Diretor, implantado ou atualizado há menos de 7 anos.

\section{E. Normalização}

\begin{tabular}{ll}
\hline Score & $\begin{array}{l}\text { Valores de Referência } \\
\text { O município dispõe de Plano Diretor, implantado ou atualizado há: }\end{array}$ \\
\hline 1,00 & Menos de 7 anos \\
\hline 0,50 & Mais de 7 anos \\
\hline 0,00 & O município não dispõe de Plano Diretor \\
\hline
\end{tabular}

\subsubsection{Legislação urbanística}

\section{A. Definição}

Existência de legislação urbanística.

\section{B. Fontes de Dados}

Prefeitura Municipal de Curitiba, site oficial (2009) e IPPUC, site oficial (2009).

\section{Método de Cálculo}

Consulta a legislação municipal para verificação de existência de legislação urbanística:

Lei do Perímetro Urbano: lei municipal $n^{\circ} 2.584 / 65$;

Lei de Zoneamento, Uso e Ocupação do Solo: lei municipal n 9.800/00; Código de Obras e Posturas: lei municipal $n^{\circ} 699 / 53$, alterada pelas leis posteriores 792/53, 3.942/71, 6.499/84, 7.633/91, 8.119/93, 8.350/93, $10.645 / 03$ e lei 11.095 decreto $212 / 07$;

Legislação sobre áreas verdes de interesse especial: leis municipais 4.557/73, 6.819/86, 7.833/91, 472/93, 8.353/93, 8.579/94, 9.806/00, 10.072/00, 921/01, 10.559/02, 1.153/04, 11.473/05, 1.181/09;

Legislação sobre área de interesse especial: 854/09, 9.802/00, 1.442/05, 9.800/00, 9.640/98, 781/96, 589/96, 562/96, 49/96, 162/96; 
Legislação de interesse social: 13.265/09, 854/09, 12.450/07, 820/06, 1442/05, 11.266/04, 9802/00, 9.801/00, 9.800/00, 250/00, 9.460/98, 1.105/97;

Parcelamento do Solo: 12.484/07, 881/07, 11.266/04, 9.800/00; Instrumentos de Planejamento Urbano: 11.266/04;

Parcelamento, edificação ou utilização compulsórios;

Imposto predial e territorial progressivo no tempo;

Desapropriação com pagamento mediante títulos da dívida pública;

Direito de preempção;

Outorga onerosa do direito de construir;

Transferência do direito de construir;

Operações urbanas consorciadas;

Estudo de impacto de vizinhança;

Monitoramento e controle do Plano Diretor.

\section{Score}

Lei do Perímetro Urbano, Lei de Zoneamento ou equivalente, Lei de Uso e Ocupação do Solo, Código de Obras, Código de Posturas, Legislação Sobre Áreas de Interesse Especial, Legislação de Interesse Social, instrumentos para o Parcelamento, Edificação ou Utilização Compulsórios, Outorga Onerosa do Direito de Construir, Operações Urbanas Consorciadas ou outros instrumentos de planejamento urbano

\section{E. Normalização}

\begin{tabular}{|c|c|}
\hline Score & $\begin{array}{l}\text { Valores de Referência } \\
\text { O município dispõe dos seguintes instrumentos: }\end{array}$ \\
\hline 1,00 & $\begin{array}{l}\text { Lei do Perímetro Urbano, Lei de Zoneamento ou equivalente, Lei } \\
\text { de Uso e Ocupação do Solo, Código de Obras, Código de } \\
\text { Posturas, Legislação Sobre Áreas de Interesse Especial, } \\
\text { Legislação de Interesse Social, instrumentos para o } \\
\text { Parcelamento, Edificação ou Utilização Compulsórios, Outorga } \\
\text { Onerosa do Direito de Construir, Operações Urbanas } \\
\text { Consorciadas ou outros instrumentos de planejamento urbano }\end{array}$ \\
\hline 0,90 & $\begin{array}{l}\text { Lei do Perímetro Urbano, Lei de Zoneamento ou equivalente, Lei } \\
\text { de Uso e Ocupação do Solo, Código de Obras, Código de } \\
\text { Posturas, Legislação Sobre Áreas de Interesse Especial, } \\
\text { Legislação de Interesse Social, instrumentos para o } \\
\text { Parcelamento, Edificação ou Utilização Compulsórios e Outorga } \\
\text { Onerosa do Direito de Construir }\end{array}$ \\
\hline 0,80 & $\begin{array}{l}\text { Lei do Perímetro Urbano, Lei de Zoneamento ou equivalente, Lei } \\
\text { de Uso e Ocupação do Solo, Código de Obras, Código de } \\
\text { Posturas, Legislação Sobre Áreas de Interesse Especial, } \\
\text { Legislação de Interesse Social, instrumento para o Parcelamento, } \\
\text { Edificação ou Utilização Compulsórios }\end{array}$ \\
\hline 0,70 & $\begin{array}{l}\text { Lei do Perímetro Urbano, Lei de Zoneamento ou equivalente, Lei } \\
\text { de Uso e Ocupação do Solo, Código de Obras, Código de } \\
\text { Posturas, Legislação Sobre Áreas de Interesse Especial, } \\
\text { Legislação de Interesse Social }\end{array}$ \\
\hline 0,60 & $\begin{array}{l}\text { Lei do Perímetro Urbano, Lei de Zoneamento ou equivalente, Lei } \\
\text { de Uso e Ocupação do Solo, Código de Obras, Código de } \\
\text { Posturas, Legislação Sobre Áreas de Interesse Especial }\end{array}$ \\
\hline 0,50 & $\begin{array}{l}\text { Lei do Perímetro Urbano, Lei de Zoneamento ou equivalente, Lei } \\
\text { de Uso e Ocupação do Solo, Código de Obras, Código de } \\
\text { Posturas }\end{array}$ \\
\hline 0,40 & $\begin{array}{l}\text { Lei do Perímetro Urbano, Lei de Zoneamento ou equivalente, Lei } \\
\text { de Uso e Ocupação do Solo, Código de Obras }\end{array}$ \\
\hline 0,30 & $\begin{array}{l}\text { Lei do Perímetro Urbano, Lei de Zoneamento ou equivalente, Lei } \\
\text { de Uso e Ocupação do Solo }\end{array}$ \\
\hline 0,20 & Lei do Perímetro Urbano, Lei de Zoneamento ou equivalente \\
\hline 0,10 & Lei do Perímetro Urbano \\
\hline 0,00 & O município não dispõe de legislação urbanística \\
\hline
\end{tabular}




\section{A. Definição}

Fiscalização por parte da administração municipal com relação ao cumprimento da legislação urbanística vigente.

\section{B. Fontes de Dados}

Informações fornecidas pela Prefeitura Municipal de Curitiba: IPPUC, URBS (2009).

\section{Método de Cálculo}

Avaliação global da Prefeitura Municipal sobre as operações de fiscalização, notificação, autuação e penalização dos responsáveis por obras e empreendimentos em desacordo com a legislação urbanística:

Operações de fiscalização de obras e empreendimentos em desacordo com a legislação urbanística municipal, notificação e autuação dos responsáveis, incluindo aplicação de multas.

\section{Score}

Operações de fiscalização, notificação e autuação dos responsáveis, incluindo aplicação de sanções mais severas como paralisação das obras ou demolição parcial ou total dos empreendimentos.

\section{E. Normalização}

\begin{tabular}{ll}
\hline Score & $\begin{array}{l}\text { Valores de Referência } \\
\text { A administração municipal tem realizado: }\end{array}$ \\
\hline 1,00 & $\begin{array}{l}\text { Operações de fiscalização, notificação e autuação dos } \\
\text { responsáveis, incluindo aplicação de sanções mais severas como } \\
\text { paralisação das obras ou demolição parcial ou total dos } \\
\text { empreendimentos }\end{array}$ \\
\hline 0,75 & $\begin{array}{l}\text { Operações de fiscalização de obras e empreendimentos em } \\
\text { desacordo com a legislação urbanística municipal, notificação e } \\
\text { autuação dos responsáveis, incluindo aplicação de multas }\end{array}$ \\
\hline 0,50 & $\begin{array}{l}\text { Operações de fiscalização de obras e empreendimentos em } \\
\text { desacordo com a legislação urbanística municipal, porém não tem } \\
\text { autuado ou aplicado qualquer sanção aos responsáveis, } \\
\text { limitando-se à notificação dos mesmos }\end{array}$ \\
\hline 0,25 & $\begin{array}{l}\text { Operações de fiscalização de obras e empreendimentos em } \\
\text { desacordo com a legislação urbanística municipal somente em } \\
\text { caso de denúncias }\end{array}$ \\
\hline 0,00 & $\begin{array}{l}\text { A administração municipal não tem realizado operações de } \\
\text { fiscalização de obras e empreendimentos em desacordo com a } \\
\text { legislação urbanística municipal }\end{array}$ \\
\hline
\end{tabular}

\section{TRÁFEGO E CIRCULAÇÃO URBANA}

\subsection{Acidentes de trânsito}

\subsubsection{Acidentes de trânsito}

\section{A. Definição}

Número de mortos em acidentes de trânsito ocorridos em vias urbanas no ano de referência, por 100.000 habitantes.

\section{B. Fontes de Dados}

Relatórios Estatísticos do BPTran (Valores Absolutos de Ocorrências em 2008). Estimativas populacionais para os municípios brasileiros - IPARDES e IBGE (2008) 


\section{Método de Cálculo}

Ferramentas auxiliares: Planilhas eletrônicas.

Levantamento do número de mortos em acidentes de trânsito ocorridos em vias urbanas no ano de 2008 :

Total geral de acidentes: 26.984;

Total de feridos em acidentes: 9.325 ;

Total de mortos em acidentes (no local): 98

População total do município no ano de referência (2008) - 1.828 .092 habitantes; O indicador é obtido através da equação:

$\mathrm{I}=P / 100.000 \mathrm{M}$

Onde:

I = indicador referente a mortes e feridos graves em acidentes de trânsito;

$\mathrm{M}=$ número de mortos em acidentes de trânsito ocorridos em vias urbanas no ano de referência.

\section{Score}

5,36 mortos $/ 100.000$ habitantes

\section{E. Normalização}

\begin{tabular}{ll}
\hline Score & $\begin{array}{l}\text { Valores de Referência } \\
\text { Número de mortos em acidentes de trânsito ocorridos em vias } \\
\text { urbanas do município no ano de referência por 100.000 habitantes }\end{array}$ \\
\hline 1,00 & Não houve \\
\hline 0,75 & 100 \\
\hline 0,50 & 200 \\
\hline 0,25 & 300 \\
\hline 0,00 & 400 ou mais \\
\hline
\end{tabular}

\subsubsection{Acidentes com pedestres e ciclistas}

\section{A. Definição}

Porcentagem dos acidentes de trânsito ocorridos no ano de referência em vias urbanas do município envolvendo pedestres e ciclistas.

\section{B. Fontes de Dados}

Relatórios Estatísticos do BPTran (Valores Absolutos de Ocorrências em 2008).

\section{Método de Cálculo}

Ferramentas auxiliares: Planilhas eletrônicas.

Levantamento do número total de acidentes ocorridos no ano de 2008, com base nos Relatórios Estatísticos do BPTran - 26.984 acidentes.

Levantamento do número de atropelamentos (envolvendo pedestres e ciclistas) no ano de 2008, com base nos Relatórios Estatísticos do BPTran - 1.052 acidentes.

Cálculo do quociente entre o número de acidentes ocorridos no ano de referência em vias urbanas do município envolvendo pedestres e o número total de acidentes, para a obtenção do score. 
D. Score

$3,89 \%$

\section{E. Normalização}

1,00

\begin{tabular}{ll}
\hline Score & $\begin{array}{l}\text { Valores de Referência } \\
\text { Porcentagem dos acidentes de trânsito ocorridos em vias urbanas } \\
\text { do município no ano de referência envolvendo pedestres e } \\
\text { ciclistas }\end{array}$ \\
\hline 1,00 & Até $5 \%$ \\
\hline 0,75 & $10 \%$ \\
\hline 0,50 & $15 \%$ \\
\hline 0,25 & $20 \%$ \\
\hline 0,00 & $25 \%$ ou mais \\
\hline
\end{tabular}

\subsubsection{Prevenção de acidentes}

\section{A. Definição}

Porcentagem da extensão de vias locais com dispositivos de moderação de tráfego em relação à extensão total de vias locais do sistema viário urbano.

\section{B. Fontes de Dados}

URBS (DIRETRAN), IPPUC (2009).

\section{Método de Cálculo}

Não existem informações disponíveis que separem as vias com dispositivos de moderação de tráfego por tipo de classificação. Foi apenas levantado o número total desses dispositivos na cidade como um todo.

Levantamento do número de dispositivos redutores de tráfego:

Radares: 128 operantes;

Lombadas eletrônicas: 22 operantes;

Lombadas físicas: 640 ;

Travessias elevadas: 91.

Cálculo da extensão do sistema viário total do município: 4.485,94 km.

Cálculo da extensão do sistema viário coberto por dispositivos de moderação de tráfego, considerando as distâncias percorridas equivalentes a cada dispositivo moderador de tráfego:

Radares: 350 m;

Lombadas eletrônicas: 100 m;

Lombadas físicas: $150 \mathrm{~m}$;

Travessias elevadas: $100 \mathrm{~m}$

Total de vias cobertas por dispositivos moderadores de tráfego: 152,1 km.

O cálculo não foi realizado pois os valores correspondem às vias de todas as características e não apenas as locais.

\section{Score}

\section{E. Normalização}




\begin{tabular}{ll}
\hline Score & $\begin{array}{l}\text { Valores de Referência } \\
\text { Porcentagem das vias locais do sistema viário urbano que } \\
\text { apresentam dispositivos de moderação de tráfego }\end{array}$ \\
\hline 1,00 & $100 \%$ \\
\hline 0,75 & $75 \%$ \\
\hline 0,50 & $50 \%$ \\
\hline 0,25 & $25 \%$ \\
\hline 0,00 & $\begin{array}{l}\text { As vias locais do sistema viário urbano não apresentam } \\
\text { dispositivos de moderação de tráfego }\end{array}$ \\
\hline
\end{tabular}

\subsection{Educação para o trânsito}

\subsubsection{Educação para o trânsito}

\section{A. Definição}

Porcentagem de escolas de nível pré-escolar, fundamental e médio, públicas e particulares, promovendo aulas ou campanhas de educação para o trânsito no ano de referência no município.

\section{B. Fontes de Dados}

Informações fornecidas pela Secretaria Municipal de Educação e IPPUC (2009).

\section{Método de Cálculo}

Levantamento do número total de escolas de nível pré-escolar, fundamental e médio, públicas e particulares, segundo dados da Prefeitura Municipal e IPPUC:

172 escolas municiais;

322 escolas particulares;

164 escolas estaduais.
Levantamento do número de escolas que têm implantado disciplinas regulares ou têm promovido campanhas de educação e sensibilização para o trânsito:

11 escolas estaduais participam do Programa Vila da Cidadania;

164 escolas estaduais participam do programa Patrulha Escolar

Comunitária;

95 escolas municipais participam do Programa Jovens Governantes;

172 escolas municipais possuem disciplinas de educação para o trânsito

em seu currículo obrigatório.

Foram desconsideradas as escolas particulares, pois não há informações sobre essas instituições.

Cálculo do quociente entre o número de escolas que dispõem de tais programas e o número total de escolas existentes no município para obtenção do score.

\section{Score}

$100 \%$

\section{E. Normalização}

1,00 


\begin{tabular}{ll}
\hline Score & $\begin{array}{l}\text { Valores de Referência } \\
\text { Porcentagem das escolas públicas ou particulares do município } \\
\text { que implantaram disciplinas ou programas de educação para o } \\
\text { trânsito no ano de referência }\end{array}$ \\
\hline 1,00 & $100 \%$ \\
\hline 0,75 & $75 \%$ \\
\hline 0,50 & $50 \%$ \\
\hline 0,25 & $25 \%$ \\
\hline 0,00 & 0 \\
\hline
\end{tabular}

\subsection{Fluidez e circulação}

\subsubsection{Congestionamento}

\section{A. Definição}

Média diária mensal de horas de congestionamento de tráfego em vias da rede viária principal.

\section{B. Fontes de Dados}

URBS - DIRETRAN.

\section{Método de Cálculo}

Pela insuficiência de dados o indicador não foi calculado.

\section{Score}

\section{E. Normalização}

\begin{tabular}{ll}
\hline Score & $\begin{array}{l}\text { Valores de Referência } \\
\text { Média diária mensal de horas de congestionamento de tráfego em } \\
\text { vias da rede principal }\end{array}$ \\
\hline 1,00 & Até 1 hora/dia \\
\hline 0,75 & 2 horas/dia \\
\hline 0,50 & 3 horas/dia \\
\hline 0,25 & 4 horas/dia \\
\hline 0,00 & 5 horas/dia ou mais \\
\hline
\end{tabular}

\subsubsection{Velocidade média do tráfego}

\section{A. Definição}

Velocidade média de deslocamento em transporte individual motorizado, observada num circuito preestabelecido de vias (rede viária principal), em horário de pico.

\section{B. Fontes de Dados}

Base georreferenciada do município fornecida pelo IPPUC (2009).

Levantamento de campo para medição da velocidade média em vias selecionadas.

\section{Método de Cálculo}

Ferramentas auxiliares: Automóvel, Cronômetro, Planilhas eletrônicas e Sistema de Informações Geográficas. 
Definição das vias da rede viária principal para os levantamentos de campo - 10 vias da rede viária principal.

Realização dos percursos nas vias em um automóvel e registro do tempo de percurso com auxílio de um cronômetro, em dois dias distintos (terça-feira e quinta-feira)

Tabulação dos dados em planilha eletrônica para cada segmento observado;

Cálculo das velocidades médias para cada segmento.

Cálculo da velocidade média observada para todos os segmentos para cada dia

Cálculo da velocidade média observada para os dois dias de pesquisa.

\section{Score}

$17,68 \mathrm{~km} / \mathrm{h}$

\section{E. Normalização}

0,38

\begin{tabular}{ll}
\hline Score & $\begin{array}{l}\text { Valores de Referência } \\
\text { Velocidade média de tráfego, no pico, em vias da rede principal ou } \\
\text { superior a } 30 \mathrm{~km} / \mathrm{h}\end{array}$ \\
\hline 1,00 & Igual ou superior a $30 \mathrm{~km} / \mathrm{h}$ \\
\hline 0,75 & $25 \mathrm{~km} / \mathrm{h}$ \\
\hline 0,50 & $20 \mathrm{~km} / \mathrm{h}$ \\
\hline 0,25 & $15 \mathrm{~km} / \mathrm{h}$ \\
\hline 0,00 & Até $10 \mathrm{~km} / \mathrm{h}$ \\
\hline
\end{tabular}

8.4 Operação e fiscalização de trânsito

\subsubsection{Violação das leis de trânsito}

\section{A. Definição}

Porcentagem de condutores habilitados que cometeram infrações em relação ao número de condutores com habilitação no município no ano de referência.

\section{B. Fontes de Dados}

Anuário Estatístico DETRAN/PR (2008).

\section{Método de Cálculo}

Ferramentas auxiliares: Planilhas eletrônicas.

Número de condutores cadastrados no ano de 2008: 1.090.273.

Número de suspensões do direito de dirigir (infrações gravíssimas e 20 pontos ou mais na $\mathrm{CNH}$ ): 42.139 .

O score é obtido através do quociente entre o número total de condutores que cometeram infrações e o número total de condutores com habilitação no ano de 2008.

\section{Score}

$3 \%$

\section{E. Normalização}




\begin{tabular}{ll}
\hline Score & $\begin{array}{l}\text { Valores de Referência } \\
\text { Porcentagem dos condutores com habilitação que cometeram } \\
\text { infrações gravíssimas ou atingiram mais de 20 pontos no ano de } \\
\text { referência no município }\end{array}$ \\
\hline 1,00 & Até $2 \%$ \\
\hline 0,75 & $4 \%$ \\
\hline 0,50 & $6 \%$ \\
\hline 0,25 & $8 \%$ \\
\hline 0,00 & $10 \%$ ou mais \\
\hline
\end{tabular}

\subsection{Transporte individual}

\subsection{1 Índice de Motorização}

\section{A. Definição}

Número de automóveis registrados no município por 1.000 habitantes no ano de referência.

\section{B. Fontes de Dados}

Frota Municipal - Frota de veículos cadastrados no Estado do Paraná (posição em julho de 2009) DETRAN;

Estimativa da população total do município IBGE (2009).

\section{Método de Cálculo}

Ferramentas auxiliares: Planilhas eletrônicas.

Levantamento do número total de veículos registrados no município em Jul/2009, segundo base de dados do DETRAN - 1.125.866 veículos;

População total do município no ano de referência - 1.828.092 habitantes;
O indicador é obtido através da equação:

$$
\mathrm{M}=P / 1000 A t
$$

Onde:

$M=$ índice de motorização;

At = número de automóveis registrados no município;

$\mathrm{P}=$ população total do município no ano de referência.

\section{Score}

615,87 autos $/ 1.000$ habitantes

\section{E. Normalização}

0,00

\begin{tabular}{ll}
\hline Score & $\begin{array}{l}\text { Valores de Referência } \\
\text { Número de automóveis por } 1.000 \text { habitantes }\end{array}$ \\
\hline 1,00 & Até 250 \\
\hline 0,75 & 300 \\
\hline 0,50 & 350 \\
\hline 0,25 & 400 \\
\hline 0,00 & 450 ou mais \\
\hline
\end{tabular}

\subsubsection{Taxa de ocupação de veículos}

\section{A. Definição}

Número médio de passageiros em automóveis privados em deslocamentos feitos na área urbana do município, para todos os motivos de viagem. 


\section{B. Fontes de Dados}

Número médio de passageiros em automóveis privados em deslocamentos feitos na área urbana do município, para todos os motivos de viagem.

\section{Método de Cálculo}

Informações fornecidas pelo IPPUC (2009):

1,44 passageiros por veículo.

O score é obtido através do cálculo do número médio de passageiros em automóveis através da média aritmética dos registros selecionados.

\section{Score}

1,44 passageiros/automóvel

\section{E. Normalização}

0,15

\begin{tabular}{ll}
\hline Score & $\begin{array}{l}\text { Valores de Referência } \\
\text { Taxa de ocupação média em deslocamentos na área urbana }\end{array}$ \\
\hline 1,00 & 4 passageiros/automóvel \\
\hline 0,66 & 3 passageiros/automóvel \\
\hline 0,33 & 2 passageiros/automóvel \\
\hline 0,00 & 1 passageiro/automóvel \\
\hline
\end{tabular}

\section{SISTEMAS DE TRANSPORTE URBANO}

\subsection{Disponibilidade e qualidade do transporte público}

\subsubsection{Extensão da rede de transporte público}

\section{A. Definição}

Extensão total da rede de transporte público em relação à extensão total do sistema viário urbano.

\section{B. Fontes de Dados}

Bases georreferenciadas fornecidas pelo IPPUC:

Sistema viário municipal;

Linhas de ônibus.

\section{Método de Cálculo}

Ferramentas auxiliares: Planilhas eletrônicas e Sistema de Informações Geográficas.

Filtragem das linhas de ônibus de forma a considerar apenas um único sentido e eliminando sobreposições.

Cálculo da extensão total da rede de transporte público - 1.320,132 km Cálculo da extensão total do sistema viário na área urbana - 4.314,102 km.

O score é obtido através do cálculo da razão entre o somatório da extensão da rede de transporte público e a extensão total do sistema viário urbano.

\section{Score}

$30,60 \%$

\section{E. Normalização}




\begin{tabular}{ll}
\hline Score & $\begin{array}{l}\text { Valores de Referência } \\
\text { Extensão da rede de transporte público em relação à extensão do } \\
\text { sistema viário }\end{array}$ \\
\hline 1,00 & $100 \%$ ou superior \\
\hline 0,75 & $80 \%$ \\
\hline 0,50 & $60 \%$ \\
\hline 0,25 & $40 \%$ \\
\hline 0,00 & Até $20 \%$ \\
\hline
\end{tabular}

\subsubsection{Frequência de atendimento do transporte público}

\section{A. Definição}

Frequência média de veículos de transporte coletivo por ônibus em linhas urbanas no município, nos dias úteis e períodos de pico.

\section{B. Fontes de Dados}

Informações disponíveis no endereço oficial da URBS na Internet (2009).

\section{Método de Cálculo}

Ferramentas auxiliares: Planilhas eletrônicas.

Levantamento das linhas principais (expressos e ligeirinhos) através das informações disponíveis no endereço oficial da URBS.

Verificação dos horários de saída dos ônibus urbanos, para viagens em dois sentidos (ida e volta) para cada linha.

Construção de planilhas com os horários de saída.

Cálculo das frequências de viagem por linha.

Cálculo da frequência média para todas as linhas urbanas.
7 minutos

\section{E. Normalização}

1,00

\begin{tabular}{ll}
\hline Score & $\begin{array}{l}\text { Valores de Referência } \\
\text { Frequência média de atendimento do serviço de transporte público } \\
\text { por ônibus nos horários de pico }\end{array}$ \\
\hline 1,00 & Até 15 minutos ou 4,00 ônibus/hora \\
\hline 0,75 & 20 minutos ou 3,00 ônibus/hora \\
\hline 0,50 & 25 minutos ou 2,4 ônibus/hora \\
\hline 0,25 & 30 minutos ou 2 ônibus/hora \\
\hline 0,00 & 35 minutos ou mais, ou 1,7 ônibus/hora \\
\hline
\end{tabular}

\subsubsection{Pontualidade}

\section{A. Definição}

Porcentagem das viagens em veículos de transporte coletivo por ônibus respeitando a programação horária.

\section{B. Fontes de Dados}

Informações fornecidas pela URBS (2009).

\section{Método de Cálculo}

Levantamento da porcentagem de viagens em veículos de transporte coletivo por ônibus respeitando a programação horária. 
D. Score

$99,8 \%$

\section{E. Normalização}

0,99

\begin{tabular}{ll}
\hline Score & $\begin{array}{l}\text { Valores de Referência } \\
\text { Porcentagem das viagens por transporte coletivo por ônibus no } \\
\text { mês analisado que respeitaram os horários programados }\end{array}$ \\
\hline 1,00 & $100 \%$ \\
\hline 0,75 & $95 \%$ \\
\hline 0,50 & $90 \%$ \\
\hline 0,25 & $85 \%$ \\
\hline 0,00 & $80 \%$ ou menos \\
\hline
\end{tabular}

\subsubsection{Velocidade média do transporte público}

\section{A. Definição}

Velocidade média de deslocamento em transporte público por ônibus (velocidade comercial).

\section{B. Fontes de Dados}

Informações fornecidas pela URBS (2009).

\section{Método de Cálculo}

Levantamento da velocidade média de deslocamento em transporte público por ônibus (velocidade comercial).

De 16 a $20 \mathrm{~km} / \mathrm{h}$ em canaletas exclusivas;
De $20 \mathrm{~km} / \mathrm{k}$ nas vias de trânsito geral.

Adoção do valor médio a partir dos dados fornecidos.

\section{Score}

$19 \mathrm{~km} / \mathrm{h}$

\section{E. Normalização}

0,45

\begin{tabular}{ll}
\hline Score & $\begin{array}{l}\text { Valores de Referência } \\
\text { Velocidade média do serviço de transporte coletivo por ônibus em } \\
\text { horário de pico }\end{array}$ \\
\hline 1,00 & Mais de $25 \mathrm{~km} / \mathrm{h}$ \\
\hline 0,75 & $25 \mathrm{~km} / \mathrm{h}$ \\
\hline 0,50 & $20 \mathrm{~km} / \mathrm{h}$ \\
\hline 0,25 & $15 \mathrm{~km} / \mathrm{h}$ \\
\hline 0,00 & Igual ou inferior a $10 \mathrm{~km} / \mathrm{h}$ \\
\hline
\end{tabular}

\subsubsection{Idade média da frota de transporte público}

\section{A. Definição}

Idade média da frota de ônibus e micro-ônibus urbanos no ano de referência no município.

\section{B. Fontes de Dados}

Informações fornecidas pela URBS (2009).

\section{Método de Cálculo}

Análise da idade média da frota de ônibus urbano no ano de 2009. 


\section{Score}

5,94 anos

\section{E. Normalização}

0,83

\begin{tabular}{ll}
\hline Score & $\begin{array}{l}\text { Valores de Referência } \\
\text { Idade média da frota de ônibus e micro-ônibus urbanos }\end{array}$ \\
\hline 1,00 & Até 5 anos \\
\hline 0,66 & 7 anos \\
\hline 0,33 & 9 anos \\
\hline 0,00 & 11 anos ou mais \\
\hline
\end{tabular}

\subsection{6 Índice de passageiros por quilômetro}

\section{A. Definição}

Razão entre o número total de passageiros transportados e a quilometragem percorrida pela frota de transporte púbico do município.

\section{B. Fontes de Dados}

Informações fornecidas pela URBS (2009).

\section{Método de Cálculo}

Levantamento do número de passageiros transportados num mês típico e da quilometragem percorrida mensalmente pelo transporte público:

Passageiros transportados por mês - 63.630 .000 passageiros;

Quilometragem mensal - 12.726.947,10 km/mês.
O score é obtido pela razão do número de passageiros pela quilometragem $\vec{N}$ percorrida.

\section{Score}

4,99

\section{E. Normalização}

0,00

\begin{tabular}{ll}
\hline Score & $\begin{array}{l}\text { Valores de Referência } \\
\text { IPK do serviço de transporte público por ônibus no ano de } \\
\text { referência (ou mês observado) }\end{array}$ \\
\hline 1,00 & Igual ou superior a 4,5 até o limite de 5 passageiros $/ \mathrm{km}$ \\
\hline 0,75 & 4 passageiros $/ \mathrm{km}$ \\
\hline 0,50 & 3,5 passageiros $/ \mathrm{km}$ \\
\hline 0,25 & 3 passageiros $/ \mathrm{km}$ \\
\hline 0,00 & Até 2,5 ou superior a 5 passageiros $/ \mathrm{km}$ \\
\hline
\end{tabular}

\subsubsection{Passageiros transportados anualmente}

\section{A. Definição}

Variação em termos percentuais do número de passageiros transportados pelos serviços de transporte público urbano no município para um período de 2 anos.

\section{B. Fontes de Dados}

Informações fornecidas pela URBS (2009) e Plano de Mobilidade Urbana e Transporte Integrado - PlanMob Curitiba, Diagnóstico (2007). 


\section{Método de Cálculo}

Ferramentas auxiliares: Planilhas eletrônicas.

Levantamento do número de passageiros transportados pelo serviço de transporte público por ônibus do município:

Ano de 2007: 763.542 .000 passageiros:

Ano de 2008: 763.560 .000 passageiros.

Cálculo da variação percentual entre o número de passageiros transportados em 2007 e 2008:

Acréscimo de $0,01 \%$ do número de passageiros transportados.

\section{Score}

Decréscimo inferior a $25 \%$.

\section{E. Normalização}

0,25

\begin{tabular}{ll}
\hline Score & $\begin{array}{l}\text { Valores de Referência } \\
\text { Foi observado para o número de passageiros transportados em } \\
\text { dois anos distintos no município: }\end{array}$ \\
\hline 1,00 & Crescimento superior a $25 \%$ \\
\hline 0,75 & Crescimento inferior a $25 \%$ \\
\hline 0,50 & O número de passageiros transportados permaneceu constante \\
\hline 0,25 & Decréscimo inferior a $25 \%$ \\
\hline 0,00 & Decréscimo superior a $25 \%$ \\
\hline
\end{tabular}

\subsubsection{Satisfação do usuário com o serviço de transporte público}

\section{A. Definição}

Porcentagem da população satisfeita com o serviço de transporte público urbano e metropolitano em todas as suas modalidades.

\section{B. Fontes de Dados}

Pesquisa de Satisfação do Usuário da RIT, realizada pelo Instituto Curitiba de Informática (ICI), 2009.

\section{Método de Cálculo}

Avaliação do resultado da pesquisa:

Número de entrevistados: 2.664;

Entrevistados usuários do sistema de transporte: 1.852 (69,5\%). Índice de Satisfação Usuários (Ponderado): 59\%.

\section{Score}

$59 \%$

\section{E. Normalização}




\begin{tabular}{ll}
\hline Score & $\begin{array}{l}\text { Valores de Referência } \\
\text { Porcentagem da população (ou dos entrevistados) que está } \\
\text { totalmente satisfeita (ou percebe o serviço como excelente) com o } \\
\text { sistema de transporte público urbano e metropolitano }\end{array}$ \\
\hline 1,00 & $100 \%$ \\
\hline 0,75 & $75 \%$ \\
\hline 0,50 & $50 \%$ \\
\hline 0,25 & $25 \%$ \\
\hline 0,00 & 0 \\
\hline
\end{tabular}

\section{$9.2 \quad$ Diversificação modal}

\subsubsection{Diversidade de modos de transporte}

\section{A. Definição}

Número de modos de transporte disponíveis na cidade.

\section{B. Fontes de Dados}

Levantamento de campo.

\section{Método de Cálculo}

Levantamento dos modos de transporte disponíveis no município:

Privado ou individual: automóvel e/ou motocicleta;

Semi-público: táxis, serviços especiais (atendimento a pessoas com

necessidades especiais);

Público, coletivo ou de massa: ônibus e/ou micro-ônibus.

\section{E. Normalização}

0,75

\begin{tabular}{ll}
\hline Score & $\begin{array}{l}\text { Valores de Referência } \\
\text { Número de modos de transporte (público, semi-público e privado) } \\
\text { que a cidade dispõe }\end{array}$ \\
\hline 1,00 & 5 ou mais \\
\hline 0,75 & 5 ou mais \\
\hline 0,50 & 3 \\
\hline 0,25 & 2 \\
\hline 0,00 & 1 (modo privado, automóvel) \\
\hline
\end{tabular}

\subsubsection{Transporte coletivo $x$ transporte individual}

\section{A. Definição}

Razão entre o número diário de viagens na área urbana ou metropolitana feitas por modos coletivos de transporte e o número diário de viagens feitas por modos individuais de transporte motorizados.

\section{B. Fontes de Dados}

Dados indisponíveis.

\section{Método de Cálculo}

Cálculo não realizado pela indisponibilidade de dados. 
D. Score

\section{E. Normalização}

\begin{tabular}{ll}
\hline Score & $\begin{array}{l}\text { Valores de Referência } \\
\text { Razão entre o número diário de viagens na área urbana feitas por } \\
\text { modos coletivos e o número diário de viagens feitas por modos } \\
\text { individuais de transporte motorizados }\end{array}$ \\
\hline 1,00 & Igual ou superior a 5 \\
\hline 0,75 & 4 \\
\hline 0,50 & 3 \\
\hline 0,25 & 2 \\
\hline 0,00 & Igual ou inferior a 1 \\
\hline
\end{tabular}

\subsubsection{Modos não motorizados x modos motorizados}

\section{A. Definição}

Razão entre o número diário de viagens na área urbana ou metropolitana feitas por modos não motorizados de transporte e número diário de viagens feitas por modos motorizados de transporte.

\section{B. Fontes de Dados}

Dados indisponíveis.

\section{Método de Cálculo}

Cálculo não realizado pela indisponibilidade de dados.

\section{Score}

\section{E. Normalização}

\begin{tabular}{ll}
\hline Score & $\begin{array}{l}\text { Valores de Referência } \\
\text { Razão entre o número diário de viagens na área urbana feitas por } \\
\text { modos não motorizados e o número diário de viagens feitas por } \\
\text { modos motorizados de transporte }\end{array}$ \\
\hline 1,00 & Igual ou superior a 2 \\
\hline 0,75 & 1,75 \\
\hline 0,50 & 1,50 \\
\hline 0,25 & 1,25 \\
\hline 0,00 & Igual ou inferior 1 \\
\hline
\end{tabular}

9.3 Regulação e fiscalização do transporte público

9.3.1 Contratos e licitações

\section{A. Definição}

Porcentagem dos contratos de operação de serviços de transporte público que se encontram regularizados.

\section{B. Fontes de Dados}

Informações fornecidas pela URBS (2009). 


\section{Método de Cálculo}

Levantamento do número total de contratos de prestação de serviço de transporte coletivo no município (concessão) - 28 contratos regulares.

Associação do score para o indicador, conforme resultado da avaliação.

\section{Score}

$100 \%$

\section{E. Normalização}

1,00

\begin{tabular}{ll}
\hline Score & $\begin{array}{l}\text { Valores de Referência } \\
\text { Porcentagem dos contratos de prestação de serviços de } \\
\text { transportes que se encontram regularizados }\end{array}$ \\
\hline 1,00 & $100 \%$ \\
\hline 0,75 & $75 \%$ \\
\hline 0,50 & $50 \%$ \\
\hline 0,25 & $25 \%$ \\
\hline 0,00 & 0 \\
\hline
\end{tabular}

\subsubsection{Transporte clandestino}

\section{A. Definição}

Participação do transporte clandestino ou irregular nos deslocamentos urbanos.

\section{B. Fontes de Dados}

Informações fornecidas pela URBS (2009).

\section{Método de Cálculo}

Levantamento sobre a existência e participação de transporte clandestino no município:

Totalmente inexistente.

\section{Score}

Inexpressiva ou inexistente, tendo sido combatidos, regulamentados ou incorporados ao sistema formal.

\section{E. Normalização}

1,00

\begin{tabular}{ll}
\hline Score & $\begin{array}{l}\text { Valores de Referência } \\
\text { A participação do transporte clandestino no sistema de transporte } \\
\text { público urbano é: }\end{array}$ \\
\hline 1,00 & $\begin{array}{l}\text { Inexpressiva ou inexistente, tendo sido combatidos, } \\
\text { regulamentados ou incorporados ao sistema formal }\end{array}$ \\
\hline 0,75 & Pequena, predominando os serviços de vans e peruas irregulares \\
\hline 0,50 & $\begin{array}{l}\text { Pequena, predominando os serviços de vans e peruas irregulares } \\
\text { e mototáxi }\end{array}$ \\
\hline 0,25 & $\begin{array}{l}\text { Expressiva, predominando os serviços de vans e peruas } \\
\text { irregulares, mototáxi e táxi-lotação }\end{array}$ \\
\hline 0,00 & $\begin{array}{l}\text { Expressiva, existindo serviços de natureza diversa como vans e } \\
\text { peruas irregulares, mototáxi, táxi-lotação, ônibus piratas e } \\
\text { automóveis }\end{array}$ \\
\hline
\end{tabular}




\subsection{Integração do transporte público}

\subsubsection{Terminais intermodais}

\section{A. Definição}

Porcentagem dos terminais de transporte urbano/metropolitano de passageiros que permitem a integração física de dois ou mais modos de transporte público.

\section{B. Fontes de Dados}

Informações fornecidas pela URBS (2009).

\section{Método de Cálculo}

Identificação do número total de terminais de transporte público urbano no município - 21 terminais.

Nenhum dos terminais possui integração modal, pois há apenas um modo de transporte público no município.

O score é obtido através do quociente entre o número de terminais com integração intermodal e o número total de terminais de transporte urbano do município.

\section{Score}

\section{E. Normalização}

0,00

\begin{tabular}{ll}
\hline Score & $\begin{array}{l}\text { Valores de Referência } \\
\text { Porcentagem dos terminais de transporte público urbano que } \\
\text { permitem integração entre dois os mais modos de transporte } \\
\text { público }\end{array}$ \\
\hline 1,00 & Mais de 75\% \\
\hline 0,75 & $75 \%$ \\
\hline 0,50 & $50 \%$ \\
\hline 0,25 & $25 \%$ \\
\hline 0,00 & 0 \\
\hline
\end{tabular}

\subsubsection{Integração do transporte público}

\section{A. Definição}

Grau de integração do sistema de transporte público urbano e metropolitano.

\section{B. Fontes de Dados}

Informações fornecidas pela URBS (2009)

\section{Método de Cálculo}

Verificação do grau de integração do sistema de transporte público urbano do município:

É praticada a integração física tarifária em terminais fechados e em estações tubo para o mesmo modo de transporte;

A integração tarifária é feita por meio de bilhete eletrônico, permitindo ao usuário utilizar dois ônibus de linhas diferentes pagando apenas uma passagem, num intervalo de 90 minutos. 
O sistema de transporte público é totalmente integrado com o uso de bilhete eletrônico para integração intermodal e de sistemas adjacentes (intermunicipais ou metropolitanos).

\section{E. Normalização}

1,00

\begin{tabular}{ll}
\hline Score & Valores de Referência \\
\hline 1,00 & $\begin{array}{l}\text { O sistema de transporte público é totalmente integrado com o uso } \\
\text { de bilhete eletrônico para integração intermodal e de sistemas } \\
\text { adjacentes (intermunicipais ou metropolitanos) }\end{array}$ \\
\hline $\begin{array}{l}\text { É praticada a integração física e tarifária temporal em terminais } \\
\text { fechados e em qualquer ponto do sistema de transporte público } \\
\text { urbano, para o mesmo modo de transporte e entre diferentes } \\
\text { modos (transferências intramodais e intermodais) }\end{array}$ \\
\hline $\begin{array}{l}\text { É praticada a integração física e tarifária temporal somente em } \\
\text { terminais fechados do sistema de transporte público urbano, para } \\
\text { o mesmo modo de transporte (transferências intramodais) }\end{array}$ \\
\hline $\begin{array}{l}\text { É praticada somente a integração física em terminais fechados do } \\
\text { sistema de transporte público urbano, para o mesmo modo de } \\
\text { transporte (transferências intramodais) }\end{array}$ \\
\hline 0,00 & $\begin{array}{l}\text { Não é praticada nenhuma forma de integração física ou tarifária } \\
\text { no sistema de transporte público urbano }\end{array}$ \\
\hline
\end{tabular}

\subsection{Política Tarifária}

\subsubsection{Descontos e gratuidades}

\section{A. Definição}

Porcentagem dos usuários do sistema de transporte público que usufruem de descontos ou gratuidade do valor da tarifa.
Informações fornecidas no site oficial da URBS (2009)

\section{Método de Cálculo}

Ferramentas auxiliares: Planilhas eletrônicas.

Levantamento da proporção de usuários com desconto ou gratuidade de tarifa:

Com descontos de $50 \%-0,86 \%$;

Com subsídio da PMC - 0,075\%;

Isentos - 5,64\%.

O score é obtido através da soma destes valores.

\section{Score}

$6,57 \%$

\section{E. Normalização}

1,00

\begin{tabular}{ll}
\hline Score & $\begin{array}{l}\text { Valores de Referência } \\
\text { Porcentagem dos embarques (ou usuários) do sistema de } \\
\text { transporte público no período de análise que tiveram desconto ou } \\
\text { gratuidade da tarifa }\end{array}$ \\
\hline 1,00 & Até $10 \%$ \\
\hline 0,75 & $20 \%$ \\
\hline 0,50 & $30 \%$ \\
\hline 0,25 & $40 \%$ \\
\hline 0,00 & $50 \%$ ou mais \\
\hline
\end{tabular}




\subsubsection{Tarifas de transporte}

\section{A. Definição}

Variação percentual dos valores de tarifa de transporte público urbano para um período de análise, comparada a índices inflacionários para o mesmo período.

\section{B. Fontes de Dados}

Informações fornecidas pela URBS em seu site oficial (2009).

Índices de Preços ao Consumidor - IBGE (2009).

\section{Método de Cálculo}

Ferramentas auxiliares: Planilhas eletrônicas.

Levantamento das tarifas de transporte público (ônibus) praticadas no município nos últimos 3 anos (2005 a 2008), segundo informações da URBS.

Cálculo da variação percentual das tarifas de transporte.

Adoção do IPCA (Índice Nacional de Preços ao Consumidor Amplo) como índice inflacionário de referência.

Levantamento dos valores acumulados para o índice no período entre 2005 e 2008;

Construção de tabela comparativa com os percentuais observados:

\begin{tabular}{cccc}
\hline DATA & TARIFA & VARIAÇÃO \% & IPCA \% \\
\hline 27/jun/05 & 1,8 & & \\
\hline 1/jan/06 & 1,8 & 0,00 & 2,43 \\
\hline 23/abr/07 & 1,9 & 5,26 & 4,6 \\
\hline 1/jan/08 & 1,9 & 0,00 & 2,87 \\
\hline TOTAL & & 5,26 & 9,9 \\
\hline
\end{tabular}

Avaliação da tabela para obtenção do score do indicador - as tarifas de transporte apresentaram aumento inferior ao IPCA para o período de análise.

\section{Score}

As tarifas de transporte público apresentaram, em relação ao índice inflacionário selecionado, aumento inferior ao índice.

\section{E. Normalização}

0,66

\begin{tabular}{ll}
\hline Score & $\begin{array}{c}\text { Valores de Referência } \\
\text { As tarifas de transporte público apresentaram, em relação ao } \\
\text { índice inflacionário selecionado: }\end{array}$ \\
\hline 1,00 & Não houve aumento da tarifa \\
\hline 0,66 & Aumento inferior ao índice \\
\hline 0,33 & Aumento equivalente ao índice \\
\hline 0,00 & Aumento superior ao índice \\
\hline
\end{tabular}

\subsubsection{Subsídios públicos}

\section{A. Definição}

Subsídios públicos oferecidos aos sistemas de transporte urbano/metropolitano.

\section{B. Fontes de Dados}

Informações fornecidas pela URBS (2009).

\section{Método de Cálculo}

Levantamento dos subsídios oferecidos aos operadores de serviços de transporte $\overrightarrow{\mathrm{G}}$ público urbano e metropolitano:

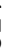


Subsídio público é dado sob forma de isenção do pagamento para o

transporte escolar de portadores de necessidades especiais (SITES -

Sistema Integrado do Ensino Especial).

Associação do score para o indicador, conforme resultado da avaliação.

D. Score

0,75

\section{E. Normalização}

0,75

\begin{tabular}{ll}
\hline Score & $\begin{array}{l}\text { Valores de Referência } \\
\text { Há subsídios: }\end{array}$ \\
\hline 1,00 & $\begin{array}{l}\text { Públicos para a totalidade do sistema de transporte público urbano } \\
\text { e metropolitano, visando à redução da tarifa de transporte }\end{array}$ \\
\hline 0,75 & $\begin{array}{l}\text { Públicos para serviços deficitários (alta capacidade ou metro } \\
\text { ferroviários) e/ou serviços especiais de transporte (pessoas com } \\
\text { necessidades especiais, etc.) }\end{array}$ \\
\hline 0,50 & $\begin{array}{l}\text { Público somente para serviços deficitários (alta capacidade ou } \\
\text { metro ferroviários) }\end{array}$ \\
\hline 0,25 & $\begin{array}{l}\text { Há somente mecanismos de subsídio interno para compensação } \\
\text { em sistema de transporte urbano com tarifa única }\end{array}$ \\
\hline 0,00 & $\begin{array}{l}\text { Não há qualquer subsídio público ou mecanismos de } \\
\text { compensação para os sistemas de transporte } \\
\text { urbano/metropolitano }\end{array}$ \\
\hline
\end{tabular}

